UNIVERSIDADE DE SÃO PAULO

FACULDADE DE FILOSOFIA, LETRAS E CIÊNCIAS HUMANAS DEPARTAMENTO DE HISTÓRIA PROGRAMA DE PÓS-GRADUAÇÃO EM HISTÓRIA SOCIAL

CARLA VIVIANE PAULINO

A viagem da U. S. Astronomical Expedition (1849-1852): observar estrelas e relatar a América do Sul

(Versão corrigida)

São Paulo

2016 


\title{
A viagem da U. S. Astronomical Expedition (1849-1852): observar estrelas e relatar a América do Sul
}

\section{(Versão corrigida)}

\author{
De acordo.
}

Profa. Dra. Mary Anne Junqueira

Tese apresentada ao Programa de PósGraduação em História Social da Faculdade de Filosofia, Letras e Ciências Humanas da Universidade de São Paulo para a obtenção do título de Doutora em História Social.

Orientadora:

Prof. ${ }^{a}$ Dr. ${ }^{a}$ Mary Anne Junqueira

São Paulo

2016 
Autorizo a reprodução e divulgação total ou parcial deste trabalho, por qualquer meio convencional ou eletrônico, para fins de estudo e pesquisa, desde que citada a fonte.

Catalogação na Publicação

Serviço de Biblioteca e Documentação

Faculdade de Filosofia, Letras e Ciências Humanas da Universidade de São Paulo

Paulino, Carla Viviane

P328v A viagem da U. S. Astronomical Expedition (18491852): observar estrelas e relatar a América do Sul / Carla Viviane Paulino ; orientador Mary Anne Junqueira. - São Paulo, 2015.

$233 \mathrm{f}$.

Tese (Doutorado)- Faculdade de Filosofia, Letras e Ciências Humanas da Universidade de São Paulo. Departamento de História. Área de concentração: História Social.

1. Estados Unidos. 2. América do Sul. 3. relato de viagem e viajantes. 4. ciência e expedições científicas. 5. Marinha norte-americana. I. Junqueira, Mary Anne, orient. II. Título. 
PAULINO, Carla Viviane. A viagem da U. S. Astronomical Expedition (1849-1852): observar estrelas e relatar a América do Sul. Tese apresentada à Faculdade de Filosofia, Letras e Ciências Humanas da Universidade de São Paulo para a obtenção do título de Doutora em História Social.

Aprovado em:

Banca examinadora

Prof. Dr. Instituição:

Julgamento: Assinatura:

Prof. Dr. Instituição:

Julgamento: Assinatura:

Prof. Dr. Instituição:

Julgamento: Assinatura:

Prof. Dr. Instituição:

Julgamento: Assinatura:

Prof. Dr. Instituição:

Julgamento: Assinatura: 
Ao Léo, companheiro de uma vida, e aos meus filhos Laura, Leonardo e Sophia. 


\section{AGRADECIMENTOS}

À CAPES pelo respaldo financeiro durante a pesquisa.

À professora Mary Anne Junqueira, que me acompanhou desde o Mestrado, com uma orientação impecável, atenta e amorosa, e que fez de mim uma pesquisadora capaz de dar conta de um tema tão complexo e de uma documentação tão difícil de ser analisada como esta do Doutorado. Ao longo de oito anos, sua presença foi fundamental em minha vida. Não há palavras suficientes para expressar o meu respeito, a minha admiração e o meu carinho. Sei que daqui, devo seguir sozinha. Você me preparou para isso, mas saiba que não irei me afastar, pois o vínculo criado nesses anos transcendeu o da orientação.

Aos professores Gabriel Passetti e Marcia Regina Barros da Silva, pelas arguições na banca de qualificação, trazendo importantes contribuições para escrita da tese.

À Maria Ligia Coelho Prado, agradeço por tanto aprendizado, não só apenas sobre História da América. Você é o exemplo que seguimos e meu carinho é imenso. Pessoas extremamente importantes para mim e para muitos, que fizeram a diferença durante meu percurso são as queridas Cecilia Azevedo, Stella Maris Scatena Franco, Katia Gerab Baggio e Maria Helena Capelato. À Stella, especialmente, deixo o meu muito obrigada pela disponibilidade em participar de minha Banca de Defesa.

Também agradeço imensamente pela disponibilidade de dois professores, que participaram de minha formação durante a graduação em História e que hoje, tenho a honra de tê-los em minha Banca de Defesa: Luiz Francisco de Albuquerque Miranda e Valéria Esteves Lima. É emocionante terminar essa etapa de minha vida tendo como examinadores, professores que 
me ajudaram a iniciá-la. Aqui agradeço novamente ao professor Gabriel Passetti por aceitar meu convite como examinador.

Durante esse longo período de estudo, entre Mestrado e Doutorado, tive a sorte fazer parte de um grupo de pesquisadores de História das Américas muito especiais. Por isso pude fazer amigos, não colegas. Nossos encontros, como bem observou a professora Cecilia Azevedo em um recente Congresso de pesquisadores de História dos Estados Unidos, alimentam o intelecto e a amizade. Assim, agradeço aos amigos que carregarei para a vida e dos quais tenho muito orgulho e admiração: Flávio Francisco, Flávio Trovão, Gabriel Passetti, Gabriela Xabay, Ivania Motta, Romilda Motta, Tereza Spyer Dulcci. Foi uma honra ter percorrido todo esse caminho árduo junto com vocês. Tudo ficou mais leve e divertido, ao mesmo tempo em que tudo ficou mais sério e bem feito. Juntos, fizemos a diferença, tenho certeza disso.

À Gabriela Xabay, deixo um agradecimento especial. Quando os prazos me consumiam e tudo parecia confuso devido à estafa mental, ela se dispôs a ajudar. Sua leitura atenta de cada capítulo e suas excelentes revisões das minhas traduções me deram forças para finalizar essa etapa. Gabriela, você foi fundamental no momento mais difícil dessa jornada. Conte comigo sempre. Sua generosidade, inteligência e amizade valem ouro. Natania Silva, sei que você amparou a Gabriela nesse processo e por isso, meu muito obrigada a você também. Ivania Motta, incluo você novamente aqui. Nós três nos amparamos, nos cuidamos e nos fortalecemos. Que essa amizade linda perdure por uma vida.

Aos queridos Valdir Santos, Emílio Cólman, Eustáquio Ornelas, Edson Bossonaro, Debora Vilella, Marília Arantes, Eline Souza, obrigada pelo apoio e pelas valiosas trocas ao longo dessa caminhada.

Ao jornalista Chris Dixon, pela generosa colaboração em minhas pesquisas sobre o oficial Archibald MacRae. 
Aos meus amigos de Curitiba, que tornam tudo mais leve: Letícia Cola, minha amiga tão querida e divertida e Edilson Silva, vocês são fundamentais em minha vida. Edilson, obrigada pela paciência enorme em formatar meu trabalho por incontáveis vezes e deixá-lo pronto para ir para a impressão. Sem você ele não teria ficado tão lindo.

Aos meus pais, agradeço o eterno apoio, admiração e confiança. Meu amor por vocês é impossível de ser medido. Aqui, incluo o meu irmão caçula Marcio Paulino, que está ao meu lado sempre, que a distância não separa, que é parte importantíssima em minha vida. Martha Virginia, minha segunda mãe, que me ensinou a pensar e me incentivou a leitura desde muito cedo. Claudia Santos, minha prima, minha irmã, que tornou meus dias mais felizes e divertidos desde que me entendo por gente. Obrigada por tudo.

A meus filhos: Laura, Leonardo e Sophia. Meu maior incentivo em terminar essa etapa sempre foi a ideia de poder, ao final, passar o máximo de tempo com seu pai e com vocês e vivermos um monte de história juntos. Espero que apesar de todos esses anos de muito trabalho, incluindo os finais de semana, eu tenha conseguido ser a mãe que vocês precisavam e precisam. Espero também ter servido de exemplo, para que percebam que na vida, temos que amar a profissão que escolhemos, e que mesmo assim, há um preço quando se quer fazer a diferença. Mas, quando nos empenhamos, o resultado vem e vale todo o esforço. Basta dar o melhor que há dentro de nós. Espero que vocês, assim como eu e seu pai, também amem suas profissões um dia.

Por último, deixo a pessoa mais importante de minha vida, meu marido, meu companheiro de quase vinte e cinco anos de jornada, Leônidas Sossai. Agradeço sua enorme paciência, seu apoio, seu respaldo financeiro, sua revisão de minhas traduções, sua leitura de minha Conclusão, quando de tão cansada, não sabia mais se havia coerência e você, com amor e atenção, leu comigo e me ajudou a finalizar essa etapa. Agradeço por que você sempre soube que esses oito anos seriam difíceis, mas nunca me cobrou por isso e 
sempre me incentivou a continuar. Nunca me cobrou presença, mesmo quando dela precisou. Você sabe amar, e só posso agradecer por ter você como companheiro. É sempre em teus braços que encontro paz e segurança. E será neles que irei me acalmar antes da defesa dessa tese, como sempre acontece nos momentos de tensão quase insuportáveis, em que corro para os seus braços, os únicos capazes de me oferecer calma e conforto. Essa tese eu dedico a você, meu amor. 


\section{RESUMO}

PAUlinO, Carla Viviane. A viagem da U. S. Astronomical Expedition (1849-1852): observar estrelas e relatar a América do Sul. 2015. $231 \mathrm{f}$. Tese de Doutorado. Faculdade de Filosofia, Letras e Ciências Humanas da Universidade de São Paulo.

O trabalho analisa a expedição astronômica realizada pela Marinha norteamericana ao Chile, durante os anos de 1849 a 1852, comandada pelo oficial e também astrônomo James Melville Gilliss. O objetivo foi compreender os interesses científicos, políticos, geopolíticos e comerciais que motivaram a viagem, bem como as imagens e representações sobre a América do Sul, especialmente do Panamá, Peru, Chile e Argentina, construídas e divulgadas através do relatório oficial da expedição, com o título "The U.S. Naval Astronomical Expedition to the Southern Hemisphere during the years (18491852)”. Esta pesquisa também procura examinar os diferentes dispositivos discursivos utilizados pelos oficiais que escreveram o relatório, James Gilliss e Archibald MacRae, discutindo dissensões e diferentes visões sobre o modo de veicular dados científicos, e também modos distintos de relatar a América do Sul.

Palavras-chave: Estados Unidos, América do Sul, relato de viagem e viajantes, ciência e expedições científicas, Marinha norte-americana. 


\begin{abstract}
This work analyzes the astronomical expedition to Chile realized by U.S. Navy, during the years of 1849 to 1852 , led by Lieutenant - and also astronomer - James Melville Gilliss. The purpose of this thesis is to comprehend scientific interests and political, geopolitical and commercial reasons that prompted the expedition, as well as to examine representations and images about South America - especially about Panamá, Peru, Chile and Argentina -, that were constructed and spread through the official travel account, named "The U.S. Naval Astronomical Expedition to the Southern Hemisphere during the years (1849-1852)". This research also aims to examine the different rhetorical devices used by officials who wrote the final report, James Gilliss and Archibald MacRae, discussing disagreements and different opinions on how to convey scientific data, and also distinct ways of portraying South America.
\end{abstract}

Keywords: United States, South America, travel writings and travelers, Science and scientific expeditions, U. S. Navy. 


\section{SUMÁRIO}

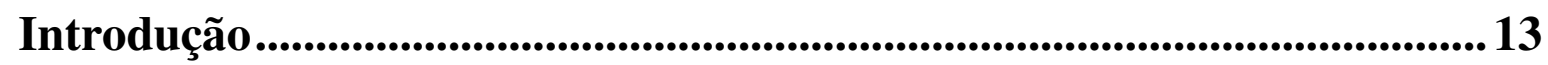

Capítulo I - James Melville Gilliss e a Expedição Astronômica: A modernizaçã̃o da U.S. Navy.................................................................................26

1.1 - Archibald MacRae — o viajante dos Andes............................................. 34

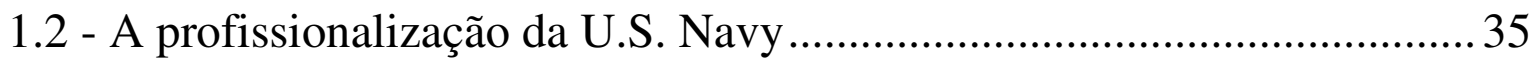

1.2.1 - Atuação de Gilliss junto ao Depot of Charts and Instruments e o

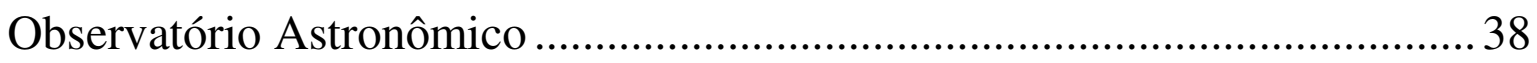

1.2.2 - Abel Upshur e as reformas da U.S. Navy: ciência e tecnologia a serviço dos interesses nacionais

1.3 - A U.S. Naval Astronomical Expedition e o contexto norte-americano: razões e justificativas para o empreendimento

Capítulo II - James Melville Gilliss e a Expedição Astronômica: Alianças e disputas político-científicas nos Estados Unidos .........................................50

2.1 - The Lazaronni scientists: em nome de uma ciência acadêmica e em

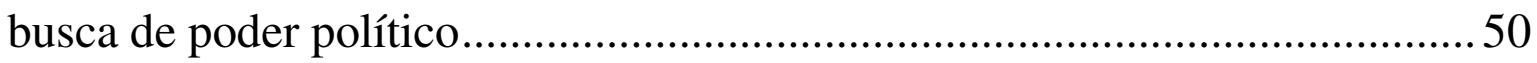

2.2 - A ideia da expedição e o Trânsito de Vênus..............................................55

2.2.1 - Os objetivos astronômicos e o planejamento da viagem.......................63

2.3 - A colaboração entre os Observatórios de distintas nacionalidades .........68

2.4 - A equipe da Expedição Astronômica ao Chile ............................................69

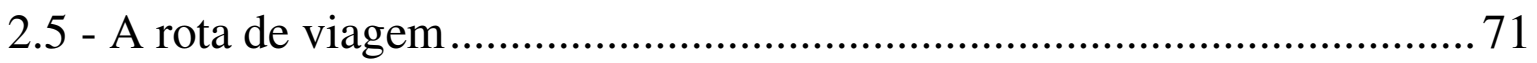

2.6 - A expedição e a cooperação transnacional ............................................... 72

2.7 - Resultados da expedição - sucessos, fracassos e boicotes........................ 74

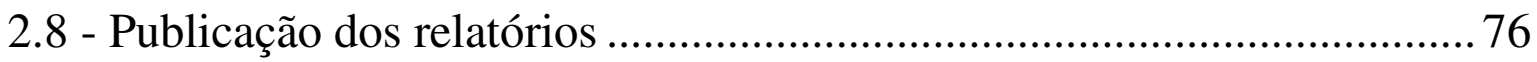

Capítulo III - O Panamá e o Peru de James Melville Gilliss ........................81

3.1 - A importância do Panamá na corrida do ouro na Califórnia .................... 81

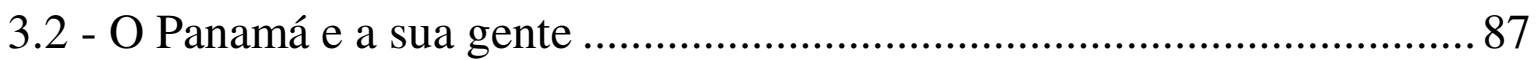

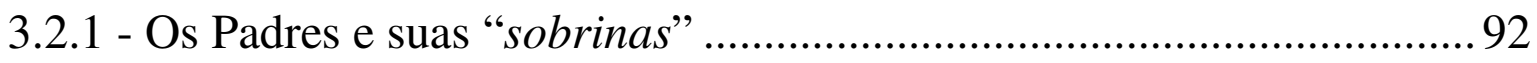

3.2.2 - Os interesses geopolíticos e econômicos ................................................94

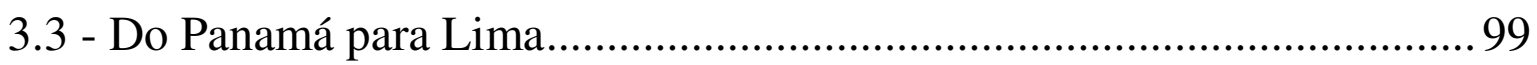


Capítulo IV - Imagens do Chile por James Melville Gilliss

4.1 - Breve relato sobre a construção do Observatório astronômico ............. 122

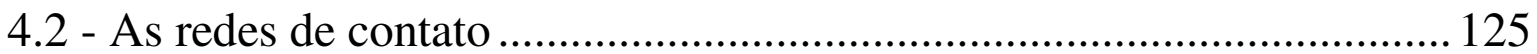

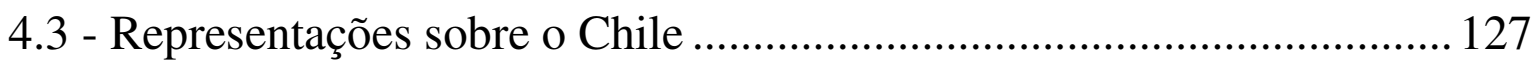

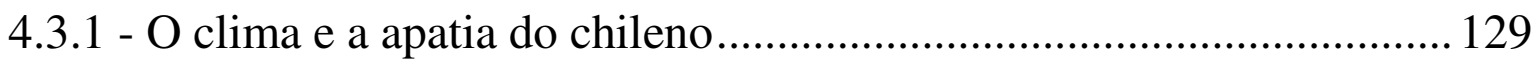

4.3.2 - A república chilena e a interferência do catolicismo........................... 135

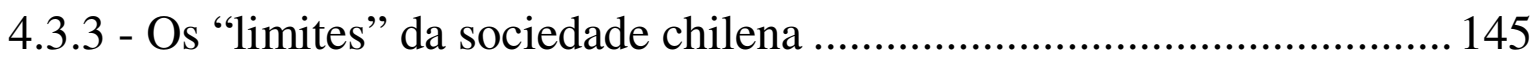

4.3.4 - O catolicismo e as deformações da sociedade.................................... 154

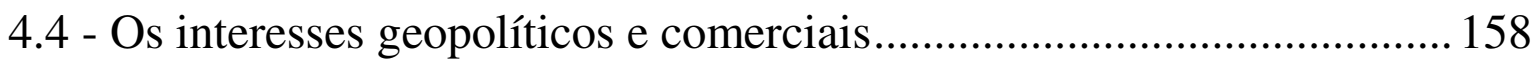

4.5 - A expedição astronômica e seu papel civilizador na América do Sul.. 166

4.6 - Ignacio Domeyko critica o relatório de viagem de Gilliss .................... 168

4.6.1 - Ignacio Domeyko refuta a ideia de "apatia chilena" .......................... 173

Capítulo V - A Argentina de Archibald MacRae....................................... 177

5.1 - Sobre Archibald MacRae.................................................................... 178

5.2 - A viagem e o relato: dilemas sobre a "fidedignidade" da escrita .......... 181

5.3 - James M. Gilliss, Archibald MacRae e as diferenças nos relatos da

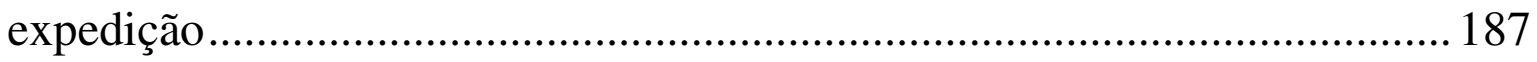

5.4 - A Confederação argentina de Justo José de Urquiza.............................. 189

5.5 - As representações de Archibald MacRae sobre a Argentina................. 192

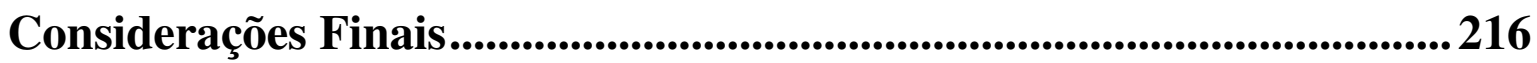

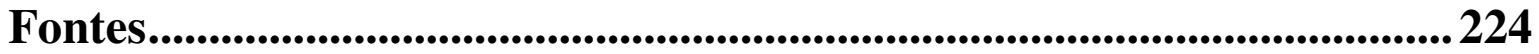

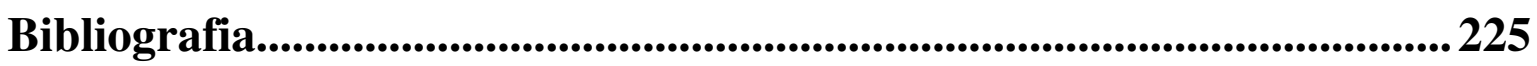




\section{Introdução}

Apresento os resultados da pesquisa que procurou estudar a expedição astronômica realizada pela Marinha norte-americana ao Chile, durante os anos de 1849 a 1852, comandada pelo oficial e também astrônomo James Melville Gilliss.

O objetivo foi compreender os interesses científicos, políticos, geopolíticos e comerciais que motivaram a viagem, bem como as imagens e representações construídas e divulgadas através do relatório oficial da expedição, com o título "The U.S. Naval Astronomical Expedition to the Southern Hemisphere during the years 1849-'50-'51-'52".'

O relatório foi majoritariamente escrito pelo comandante da expedição, embora tenha a contribuição de especialistas de diversas áreas que analisaram o material recolhido durante a viagem. Gilliss escreveu sobre os países que visitou, quais sejam, Panamá, Peru e Chile e o oficial Archibald MacRae escreveu sobre a Argentina.

Embora a expedição carregasse objetivos variados, a U.S. Navy, a Marinha de guerra dos Estados Unidos, enviou Gilliss e sua equipe ao Chile com a missão científica de lá instalar um observatório astronômico, e assim, realizar importantes observações no campo da Astronomia. O objetivo principal da expedição era aprimorar os cálculos da paralaxe solar e estelar, fato que tornaria possível obter as medidas exatas da unidade astronômica (distância da terra ao sol) e assim, obter cálculos precisos das distâncias em terra e em mar. Devido à importância destes cálculos, acredito que este foi o principal elemento motivador para a liberação de fundos para esta expedição pelo governo norte-americano.

\footnotetext{
${ }^{1}$ GILLISS, James Melville. The U.S. Naval Astronomical Expedition to the Southern Hemisphere during the years 1849-'50-'51-'52. Washington: A.O.P. Nicholson Printer, 1855. Vls.I, II, III, VI.
} 
A partir dessa viagem, ou motivado por ela, veremos que Gilliss cultivou relações com acadêmicos locais e investidores norte-americanos, interessados em expandir seus negócios ao sul do Equador. No que se refere à ciência, veremos que uma enorme rede de contatos foi criada a partir dos interesses em torno da expedição astronômica, principalmente entre Estados Unidos, Chile e cientistas da atual Alemanha, indicando assim uma movimentação desses países, paralelo ao esforço inglês, em torno da busca de um lugar de destaque mundial no campo científico.

No intervalo entre as séries de observações, Gilliss viajou pelo Chile, registrando suas impressões sobre o local, a fim de cumprir a agenda de dados que o oficial deveria colher sobre os locais visitados. Veremos que em seu percurso de ida, o oficial registrou suas impressões sobre o Panamá e o Peru, além de realizar uma interessante análise sobre os norte-americanos que com ele embarcaram até o Panamá, para depois seguirem à Califórnia, em busca de ouro. O oficial Archibald MacRae, ao fim da expedição, viajou pelo interior da Argentina e produziu um curto, porém interessante relato de sua viagem e nos trouxe novas perspectivas para analisar o relatório oficial da expedição. Veremos que MacRae rivalizava com Gilliss, desacerto que refletiu no relatório de viagem que escreveu incluído no relatório oficial da expedição.

O resultado da expedição foi publicado em 1855, em quatro alentados volumes, sendo estes, as principais fontes documentais desta pesquisa, as quais foram compreendidas aqui como fonte e objeto.

Ainda que a expedição carregasse primordialmente objetivos científicos, esses não eram os únicos, como já mencionado. A historiadora Mary Anne Junqueira alerta que, entre 1838 e 1901, a U. S. Navy realizou 12 (doze) viagens para a América Latina, as quais carregavam interesses diversos, relacionados entre si no que se refere ao objetivo de compreender de forma mais aprofundada a América do Sul, ainda considerada pouco 
conhecida, principalmente durante a primeira metade do século $\mathrm{XIX}^{2}$. Justifica-se assim o particular interesse em descrever os países visitados e relatar o seu potencial para o comércio e a construção de canais marítimos e ferroviários. $^{3}$

Após cerca de três anos no Chile, a expedição retornou aos Estados Unidos e Gilliss deu início à escrita e preparação dos relatórios da viagem. Chama à atenção o número de impressões realizadas para cada relatório: seis mil cópias dos dois primeiros volumes, e cinco mil cópias para os demais. Embora não tenha sido possível mapear a distribuição desses relatórios, foi possível descobrir que, por muitos anos, seus registros astronômicos foram úteis para o desenvolvimento da Astronomia.

A partir da análise do relatório da expedição e de toda a tramitação feita pelo governo para que a Marinha obtivesse autorização e subsídio financeiro para realizar a viagem, podemos afirmar que havia a intenção por parte dos Estados Unidos de dominar saberes relacionados à ciência, à cultura, além dos relativos à geopolítica, saberes esses fundamentais para se promover aquilo que os intelectuais do campo da crítica pós-colonial chamam de "cultura imperial". Em um período em que a Inglaterra se empenhava em demarcar sua atuação na região e se beneficiar das mais variadas formas, tais como influência política, acordos comerciais e construções de vias férreas, os Estados Unidos se movimentaram em direção aos irmãos do Sul a fim de minimizar a atuação inglesa e demarcar sua influência na região. Para tanto, era preciso, antes de tudo, conhecê-la. Essa intenção norte-americana tornouse mais evidente na medida em que analisei as detalhadas descrições sobre as regiões visitadas, contemplando fauna, flora, clima, religião, regimes de

\footnotetext{
${ }^{2}$ Cf. JUNQUEIRA, Mary A.. "Ciência, técnica e as expedições da marinha de guerra norte-americana, U.S. Navy, em direção à América Latina (1838-1901)". Varia história. [online]. 2007, vol.23, n.38, pp. 334-349.

${ }^{3}$ Sobre tais interesses, foram encontrados dois trabalhos: O'BRIEN, Thomas. Making the Americas: The United States and Latin America from the age of revolutions to the era of globalization. Albuquerque: Universuty of New Mexico Press, 2007; FIFER, Valerie J. United States perceptions of Latin America, 18501930: a "New West" south of Capricorn?. Manchester: Manchester University Press, 1991.
} 
governo, instituições políticas, sociedades e culturas locais, bem como o potencial para investimento por parte dos Estados Unidos. Assim, a expedição astronômica carregou o objetivo implícito de reunir informações diversificadas sobre a costa oeste da América do Sul.

Embora a U.S. Astronomical Expedition tenha sido um importante empreendimento do governo, apresentando como resultado final dados importantes para os interesses científicos e políticos do país, bem como uma rica - ainda que duvidosa - descrição dos países sul-americanos já citados, existem poucos trabalhos tratando da expedição fora do âmbito da Astronomia. Não encontramos pesquisas no campo das Ciências Humanas, cujo foco central seja a expedição em si. Não há, portanto, trabalhos que abordem de forma aprofundada as representações sobre a América do Sul construídas pelos viajantes que escreveram o relatório da viagem. Tampouco há trabalhos buscando compreender essa expedição no âmbito da inter-relação entre política, cultura e ciência, bem como a circulação de ideias promovidas a partir da expedição propriamente dita e, posteriormente, através dos relatórios da viagem. Outro aspecto relevante que ainda não havia sido estudado a partir dessa viagem, diz respeito às tensões existentes entre os interesses científicos nacionais e a necessidade de cooperação transnacional, em especial no campo da Astronomia. Por fim, a ausência de pesquisas que verifiquem a importância das Américas nos relatórios de viagem da expedição, legitimou a investigação aqui realizada.

\section{Sobre literatura de viagem}

Nas últimas décadas, uma nova leva de pesquisadores sobre literatura de viagem ofereceu novas discussões sobre esse tipo de documento. De fonte fidedigna, o relato de viagem passou a ser considerado produto da viagem, fortemente carregado de ideias pré-concebidas dos viajantes. Buscando uma compreensão mais aprofundada sobre a forma como os relatos vêm sendo 
compreendidos e reposicionados no estudo sobre as representações do "outro", as leituras de autores como Jam Borm, Tim Youngs, Peter Hulme e Glenn Cooper nos forneceu bases sólidas e críticas para direcionar a análise feita por mim do relatório da expedição. Ao discutir sobre os diferentes tipos de relato, bem como as diversas possibilidades de interpretação que a eles podem ser atribuídas, Jam Borm nos mostra que os relatos de viagem são um corpo documental muito diferenciado entre si, visto que viajantes com interesses, crenças e objetivos variados publicaram suas impressões sobre um determinado local por eles visitado. Desse modo, ele sublinha a heterogeneidade que caracteriza o documento, elaborado, em geral, a partir de formas narrativas distintas e matizados a partir de determinados preceitos teóricos, como por exemplo, o discurso científico, o religioso ou o comercial, ao mesmo tempo em que indica a existência de elementos autobiográficos nas fontes. ${ }^{4}$

Os relatos podem ser escritos de diferentes formas: cartas, diário, relatórios, entre outras. Gilliss e seus subordinados produziram um relatório de viagem, cujos volumes não apresentam uma ordem cronológica ou factual, mesclando dados científicos com descrições sobre os locais visitados, os quais foram representados a partir das impressões pessoais de quem os descreveu. Veremos que os dois oficiais que contribuíram com a escrita do relatório oficial elaboraram ou reforçaram imagens sobre a América do Sul de formas diferentes, ainda que em ambas predominassem estereótipos e visões negativas sobre a região. Veremos, inclusive, que a escrita de Gilliss tornouse muitas vezes contraditória, indiciando a composição de uma redação textual realizada em momentos distintos, que carregavam impressões e sentimentos pessoais que oscilavam e destoavam entre si. Há, portanto, nos

\footnotetext{
${ }^{4}$ Cf. BORM, Jam. "Defining travel: on travel book, travel writing and terminology". In HOOPER, Glenn; YOUNGS, Tim (ed). Perspectives on travel writing. Hants/Vermont: Ashgate, 2004. Ver também: HULME, Peter and YOUNGS, Tim(Orgs). The cambridge companion to travel writing. Cambridge University press, 2002.
} 
relatos de viagem, uma natureza híbrida, em que inúmeros discursos vão compondo a narrativa, como observa Borm.

Creio que mais importante do que classificar o documento em um gênero específico, para nós, historiadores, seja perceber e analisar os diferentes discursos nele contidos, as motivações da escrita e o impacto que o relato gerou em determinados públicos. Esta foi minha preocupação primordial durante a escrita desta tese, buscando compreender os aspectos mobilizadores que direcionaram a escrita dos oficiais e assim, muitas vezes desconstruir este relatório de viagem.

Importou analisar, mais do que as formas de representação, a representação em si, e a intenção contida naquilo que foi produzido. Nesse sentido, é notória a importância dos documentos de viagem, não apenas por serem bastante consumidos pelo público do século XIX, como por sua riqueza descritiva e multiplicidade discursiva, e seu poder de criar imagens sobre a égide que impera neste tipo de fonte - o ato de registrar aquilo que os olhos viram. Tal afirmação pressupõe uma 'verdade', mas uma verdade manipulada pelo escritor e por sua vez manipulada pelos leitores. ${ }^{5}$

Joan Pau Rubiés chama a atenção para a importância da Etnografia e da Etnologia na construção dos relatos de viagem. O autor observa que esses campos, tiveram um papel fundamental, não apenas para o entretenimento europeu, mas também para os assuntos filosóficos e discussões que buscavam confirmar a existência de características humanas universais. $\mathrm{O}$ autor fala de um impulso etnográfico europeu, que predominou principalmente a partir do Renascimento e que foi resultado de uma combinação única de expansão colonial e transformação intelectual presentes no período. Firmada como discurso acadêmico, baseado em estudos comparativos e classificatórios no século XIX, a Etnologia na verdade existiu dentro dos campos dos saberes humanísticos e aparece principalmente nos relatos de viagem, nos informando

\footnotetext{
${ }^{5}$ BORM, op.cit., p.20.
} 
sobre debates específicos da época, tais como as capacidades e origens do índio americano, a influência do clima nas características dos povos visitados ou a existência de estágios na história da civilização. ${ }^{6}$ Aqui, é importante lembrar que James Gilliss era um homem da ciência e, embora seu foco de interesse fosse a Astronomia, frequentava as rodas de discussão científica, nas quais o tema da Etnologia esteve fortemente presente nas instituições científicas por ele frequentada. Tanto é assim, que seus prognósticos sobre os países visitados basearam-se no clima e nas principais "raças" que predominavam em tais regiões, embora, como veremos, os preconceitos raciais que eram de domínio público e muito fortes entre as elites norteamericanas foram os principais "guias" da viagem de Gilliss.

No final da década de 1980 e ao longo de 1990, alguns historiadores brasileiros voltaram-se para o tema, produzindo trabalhos interessantes sobre os relatos de viagem, voltando-se principalmente para o estudo de relatos de viajantes europeus. ${ }^{7}$ Todavia, pouco se estudou sobre relatos produzidos especificamente por viajantes norte-americanos e tão pouco buscou-se verificar a existência de certas especificidades em seus discursos. Movida também por esta lacuna existente na historiografia brasileira, busco aqui contribuir com os estudos sobre as imagens e representações construídas por norte-americanos em relatos de viagens sobre a América do Sul.

\section{Literatura de viagem e crítica pós-colonial}

Para analisar os relatórios produzidos pela U.S. Astronomical Expedition foram importantes as reflexões de alguns autores que trabalham

\footnotetext{
${ }^{6}$ Sobre este assunto ver RUBIÉS, Joan Pau. Travel writing and ethnography. In HULME, Peter and YOUNGS, Tim (Orgs). The cambridge companion to travel writing. Cambridge University press, 2002. p. $242-43$.

${ }^{7}$ Ver, por exemplo, a importante produção: VÁRIOS AUTORES. Revista da USP (Dossiê o Brasil dos Viajantes), São Paulo: n. 30, 1996. Trabalhos mais recentes podem ser vistos em VÁRIOS AUTORES. Revista Brasileira de História. (Dossiê Viagens e Viajantes) São Paulo: Anpuh/humanitas, vol.22, n.44, 2002.
} 
dentro do campo conhecido como crítica pós-colonial, uma vez que estes vêm contribuindo para um melhor entendimento do fenômeno do imperialismo, das relações e conflitos entre Norte e Sul e das implicações próprias da globalização. Uma das características que particularizam o trabalho de alguns desses intelectuais é pensar as relações desiguais de poder através do prisma da política e da cultura. ${ }^{8}$

Edward Said, autor amplamente reconhecido como um dos fundadores do campo da crítica pós-colonial, em seu livro Cultura e Imperialismo, afirma que "os escritores estão profundamente ligados à história de suas sociedades, moldando e moldados por essa história e suas experiências sociais em diferentes graus". ${ }^{9} \mathrm{O}$ autor nos mostra que as produções literárias não estão desconectadas do contexto cultural, econômico e político em que seus autores estão imersos. Sendo assim, produções como os romances e a literatura de viagens reproduziram um determinado tipo de discurso que posicionou o homem europeu e, a meu ver, também o norte-americano, bem como o "seu mundo ocidental" e seus respectivos valores, como superiores em relação ao "resto" do mundo, delimitando assim o espaço doméstico e os outros lugares. Tais produções acabaram por construir imagens estereotipadas sobre o outro, enfatizando tudo aquilo que possa diferenciar o homem oriundo de um centro, difusor de civilidade e progresso, dos demais. Ao analisar a produção cultural e mostrar que o discurso construído por grandes escritores reproduziram valores imperialistas, Said demonstrou que a cultura não pode ser vista como algo separado da sociedade e da política.

Também ancorada em teorias formuladas no campo da crítica póscolonial, em Mary Louise Pratt, vemos que ao entrar em contato com o outro, o viajante, ao elaborar o seu discurso, apropria-se de aspectos culturais que

\footnotetext{
${ }^{8}$ Para uma introdução do campo da crítica pós-colonial, ver: WILLIANS, Patrick e CHRISMAN, Laura, (org.). Colonial discourse and post-colonial theory. A introduction. In Colonial discourse and post-colonial theory. A reader. New York: Columbia University Press, 1994.

${ }^{9}$ SAID, Edward W. Cultura e Imperialismo. São Paulo: Companhia das Letras, 1995, p.23.
} 
observa - a cultura, as falas, os costumes desse outro e que constituem o seu texto $^{10}$. Sendo assim, o viajante não é um observador neutro e portanto não pode haver uma divisão estanque entre as culturas. O seu discurso não é apenas a repetição dos paradigmas científicos ou culturais europeus dos séculos XVIII e XIX, mas é também uma cunhagem, um encontro, um choque, e portanto, a mutação desses paradigmas diante de um mundo, de um conjunto de dados que esses paradigmas não supunham. No entanto, nem sempre esse encontro se sobrepõe à bagagem que o viajante carrega. ${ }^{11}$

A autora analisa os relatos de viagem entendendo sua construção a partir do que ela chama de zona de contato, lugar comum em que se dão os encontros entre os viajantes e os povos visitados, constituindo-se em "espaços sociais onde culturas díspares se encontram, se chocam, se entrelaçam uma com a outra, frequentemente em relações extremamente assimétricas de dominação e subordinação". "Veremos que Gilliss não demonstrou em seu discurso uma mudança significativa de olhar, fato que pode ser explicado pela constante companhia de norte-americanos, que lhe serviram muitas vezes como informantes sobre o Chile, por exemplo.

Acredito que os relatórios de viagem da U.S. Astronomical Expedition estão inseridos naquilo que Ricardo Salvatore, em seu livro Imágenes de um Império, chama de máquina representacional. Segundo este autor, a teoria pós-colonial permitiu pensar a América do Sul em outra chave e perceber que a região foi alvo do olhar norte-americano desde a primeira metade do século XIX. Para Salvatore, os Estados Unidos pretendiam, desde os seus primórdios, o estabelecimento de uma espécie de império informal na América do Sul. Para tanto, possibilitaram a criação de um conjunto de representações sobre a região que incluía imagens divulgadas em feiras e

\footnotetext{
${ }^{10}$ PRATT, Mary Louise. Introdução: crítica na zona de contato. In: Os olhos do império - relatos de viagem e transculturação. São Paulo: EDUSC, 1999.

${ }^{11}$ Cf. PAULINO,Carla Viviane. O Império do atraso, op.cit. Introdução.

${ }^{12}$ PRATT, op.cit., p. 27.
} 
exposições universais, notícias e reportagens em jornais e revistas, relatos de viagem, exibições realizadas em importantes museus dos Estados Unidos e trabalhos missionários. Ressalta-se, neste empreendimento, o papel central da academia norte-americana, que contribuiu significativamente nesse processo, endossando e divulgando imagens estereotipadas sobre a América do Sul. ${ }^{13}$

Por ser o relato de viagem o principal meio de divulgação de imagens sobre o outro nos Estados Unidos, como afirma o autor, entre 1820-1860, período que Salvatore caracteriza como um momento de engajamento mercantil, acreditamos que essa obra, como parte fundamental da máquina representacional no período, exerceu um papel importante na produção de imagens sobre a América do Sul. ${ }^{14} \mathrm{O}$ relatório produzido pelos oficiais colaboraram para a produção da imagem de um outro inferiorizado, ao mesmo tempo em que reforçou a ideia de serem os Estados Unidos preeminentes entre os países das Américas ${ }^{15}$.

Em obra mais recente, Salvatore discute sobre a importância da elaboração de determinados saberes a partir de pesquisas nacionais. Junto a essa preocupação, sobre o lugar de enunciação desses saberes, e de como este deve servir primeiramente a seu país, está a necessidade de universalizá-lo. Sendo assim, para este autor, a construção do saber e seu compartilhamento se dá a partir de uma tensão entre o local e o transnacional. ${ }^{16}$ Ao estudar as redes de contatos científicas nas quais Gilliss estava inserido, tais conflitos e tensões, em meio a uma cooperação necessária, se mostraram claros.

\footnotetext{
${ }^{13}$ SALVATORE, Ricardo D. "The enterprise of knowledge: representational machines of informal Empire" In LEGRAND, Catharine C.; SALVATORE, Ricardo D. (orgs.). Close Encounters of Empire: Writing the Cultural History of. U.S. - Latin American Relations. Durham: Duke University Press, 1998, p. 81.

${ }^{14}$ Neste período, Salvatore indica que os Estados Unidos estavam focados em expandir sua rede de comércio com a América do Sul. Segundo este autor, "Suas narrativas de viagem, 'fluxo de preços' e artigos de jornal contribuíram para um preludial mapeamento da América do Sul dentro da órbita do conhecimento norteamericano". Idem, p. 12.

${ }^{15}$ Sobre este assunto ver SALVATORE, Ricardo D. Imágenes de un Imperio. Estados Unidos y las formas de representación de América Latina. Buenos Aires: Editorial Sudamerica, 2006.

${ }^{16}$ SALVATORE, Ricardo. Introducción e los lugares del saber. In: Los lugares del saber. Contextos locales y redes transnacionales en la formación del conocimento moderno. Buenos Aires: Beatriz Viterbo Editora, 2007.
} 
Desta forma, os relatórios produzidos pela U.S. Astronomical Expedition foram analisados a partir do campo que privilegia como tema de estudo a cultura imperial norte-americana, em concomitância com a colaboração transnacional.

Nesta tese, como vimos, discutiremos a expedição a partir de alguns temas-chave, a fim de compreendermos a viagem. Assim, os embates entre a ciência e a política, a pesquisa biográfica de James Melville Gilliss e de Archiblad MacRae, a compreensão do funcionamento da Marinha de guerra norte-americana, os interesses comerciais e geopolíticos do país, juntamente à análise do desenvolvimento da Astronomia e de seus principais interesses e objetivos na primeira metade do século XIX, nos dão as informações necessárias para a compreensão dos objetivos implícitos e explícitos da viagem, bem como das representações construídas pelos oficias viajantes.

$\mathrm{O}$ estudo sobre a Astronomia mundial e norte-americana nos auxiliou na conformação da hipótese de que um esforço transnacional de cooperação, junto a uma corrida nacional pela busca da paralaxe solar, ocorreu simultaneamente a um projeto que visava imprimir uma espécie de cultura imperial norte-americana entre os países da América do Sul. Sendo assim, iniciaremos essa viagem a partir da compreensão deste aspecto.

Antes de apresentar os capítulos da tese, informo ao leitor que os excertos retirados do relatório da expedição astronômica estão em inglês nas notas de rodapé e foram traduzidos para o português no corpo do texto. Todas as traduções são minhas.

No primeiro capítulo dessa tese, veremos que a expedição astronômica para a América do Sul estava fortemente vinculada aos interesses científicos e geopolíticos norte-americanos do período bem como à trajetória profissional do seu comandante, James Melville Gilliss. Também procuro demonstrar que 
a expedição é devedora do movimento reformador no interior da Marinha norte-americana; a iniciativa da viagem, todavia, foi de Gilliss, e não dos superintendentes da U.S. Navy. A expedição contou ainda com o apoio dos mais importantes nomes da ciência daquele período, vinculados a importantes instituições acadêmicas. Veremos também como se deu os embates entre os cientistas desse período, especialmente aqueles que buscavam uma forma de profissionalizar seu ofício e conquistar um espaço institucionalizado dentro do país e do governo através da ciência.

O capítulo dois apresenta um grupo influente de cientistas e relaciona estes ao processo de obtenção da autorização do governo para que a expedição astronômica fosse realizada. Em seguida, apresento como surgiu a ideia dessa viagem e os elementos científicos do campo da Astronomia que a motivaram, além de sua organização, objetivos e redes de contatos firmadas para tornar a expedição possível. Por fim, apresento os resultados astronômicos obtidos e analiso a elaboração do relatório oficial da viagem.

O capítulo três analisa o segundo momento da expedição, qual seja, a narrativa de Gilliss quando em direção ao Chile. Aqui, veremos as imagens e representações construídas pelo autor primeiro sobre uma camada pobre de norte-americanos que com ele se dirigiu dos Estados Unidos até o Panamá, para depois seguirem viagem à Califórnia, em busca do ouro. Na sequência, veremos como Gilliss retratou o país e sua gente e, após seguir viagem para o Chile, as imagens que construiu sobre o Peru.

O quarto capítulo analisa a parte do relatório oficial em que Gilliss narrou sua estadia no Chile. Iniciaremos pela construção do Observatório Astronômico, seguindo com a apresentação do cotidiano de observações astronômicas e uma análise sobre as redes de contatos científicas que tomaram forma a partir da expedição. Por fim, veremos as contraditórias representações construídas pelo oficial, além de uma interessante crítica ao 
relatório feita no mesmo ano de sua publicação, em 1855, por Ignácio Domeyko, um geólogo polonês naturalizado chileno.

O quinto e último capítulo desta tese procura compreender a intrigante narrativa de Archibald MacRae sobre o interior da Argentina. Veremos inicialmente a imagem que oficial tinha sobre Gilliss e sua produção do relatório, a partir da análise de cartas pessoais que MacRae enviou à família. Seguiremos analisando as imagens construídas pelo autor sobre o país, as quais buscam um distanciamento daquelas construídas pelo capitão desta expedição. Por fim, analisaremos os diferentes dispositivos discursivos utilizados por Gilliss e MacRae na escrita de seus relatos e abordaremos a identificação, a partir da documentação encontrada e analisada nesta tese, da necessidade de mudança na forma de elaboração desses relatórios devido à consolidação das especialidades científicas que já estão presentes nesse momento e que marcaram as críticas feitas pelos oficiais da expedição e por outros cientistas sobre alguns temas que foram desenvolvidos no relatório escrito por Gilliss. 


\section{Capítulo I - James Melville Gilliss e a Expedição Astronômica: A modernização da U.S. Navy}

A expedição astronômica para a América do Sul está fortemente vinculada aos interesses científicos e geopolíticos norte-americanos do período, bem como à trajetória profissional do seu comandante, James Melville Gilliss. No entanto, veremos também que a expedição, ainda que relacionada aos rumos políticos do país e devedora do movimento reformador no interior da Marinha norte-americana, nasceu da iniciativa de Gilliss e teve como principais apoiadores alguns dos mais importantes nomes da ciência daquele período.

Sendo assim, neste capítulo apresentaremos uma análise que relaciona e investiga o Capitão Gilliss - entendimento necessário para compreendermos a forma como ele enxergou os lugares que visitou - com o seu percurso profissional dentro da Marinha de Guerra. Para tanto, conheceremos também aspectos relevantes sobre a U.S. Navy e alguns dos seus principais líderes em períodos particularmente importantes na carreira de Gilliss entre o final de 1830 até o final de 1850 .

Durante o processo de pesquisa, ficou clara a importância da atuação de algumas academias científicas junto ao Governo Federal, pois muitas se empenharam para tornar possível a expedição comandada por Gilliss e, de algum modo, participarem dela. Veremos também como se deu os embates entre os cientistas desse período, especialmente aqueles que buscavam uma forma de profissionalizar seu ofício e conquistar um espaço institucionalizado dentro do país e do governo, através da ciência.

Filho de George Gilliss, agente fiscal do Governo Federal, James Melville Gilliss nasceu em Georgetown, Washington, em 1811. Aos quinze anos de idade, em 1826, ingressou na Marinha norte-americana como 
Aspirante, e após três anos a serviço da instituição graduou-se — nas palavras de seu biógrafo Benjamin Gould — com "honra" nos testes oficiais. ${ }^{1}$

No que se refere às promoções, as relações políticas dentro da U.S. Navy eram importantes, pois a escolha dos líderes que estariam à frente de expedições ou de qualquer missão dentro ou fora dos Estados Unidos eram, em geral, escolhas dos Secretários da Marinha, que também faziam as indicações para que os oficiais escolhidos alcançassem outra patente e fizessem carreira progressivamente dentro da Marinha. Ademais, em geral, os aspirantes que alcançaram patentes de oficiais eram gentlemen, parte da elite norte-americana. ${ }^{2}$

Em 1831, Gilliss alcançou a patente de Midshipman (guarda-marinha ou aspirante a oficial). Gould, que além de seu biógrafo foi um importante cientista (astrônomo e matemático) e amigo de Gilliss, nos conta que após os anos iniciais na Marinha, em 1831 ele pediu licença e iniciou seus estudos científicos na University of Virginia. No entanto, por problemas de saúde lá permaneceu por menos de um ano. Em 1835, foi à Paris por seis meses com o objetivo de estudar Astronomia.

\footnotetext{
${ }^{1}$ GOULD, Benjamin Apthorp. "Biographical Memoir of James Melville Gilliss". In: THB Annual of the National Academy of Sciences for 1866. Cambridge: Welch, Bigelow, and Company: 1867, p.137. Disponível em: http://www.nasonline.org/publications/biographical-memoirs/memoir-pdfs/gilliss-james.pdf. Acesso em 10/04/2012.

${ }^{2}$ Cf: LEEMAN, William P. The Long road to Annapolis: the founding of the Naval Academy and the emerging American republic. North Carolina; The University of North Carolina Press, 2010. p.104; pp.1523.; PONKO, Vincent Jr. Ships, Seas, and scientists: U.S. Naval exploration and discovery in the nineteenth century. Annapolis, Naval Institute Press, 1974. p. 153.
} 


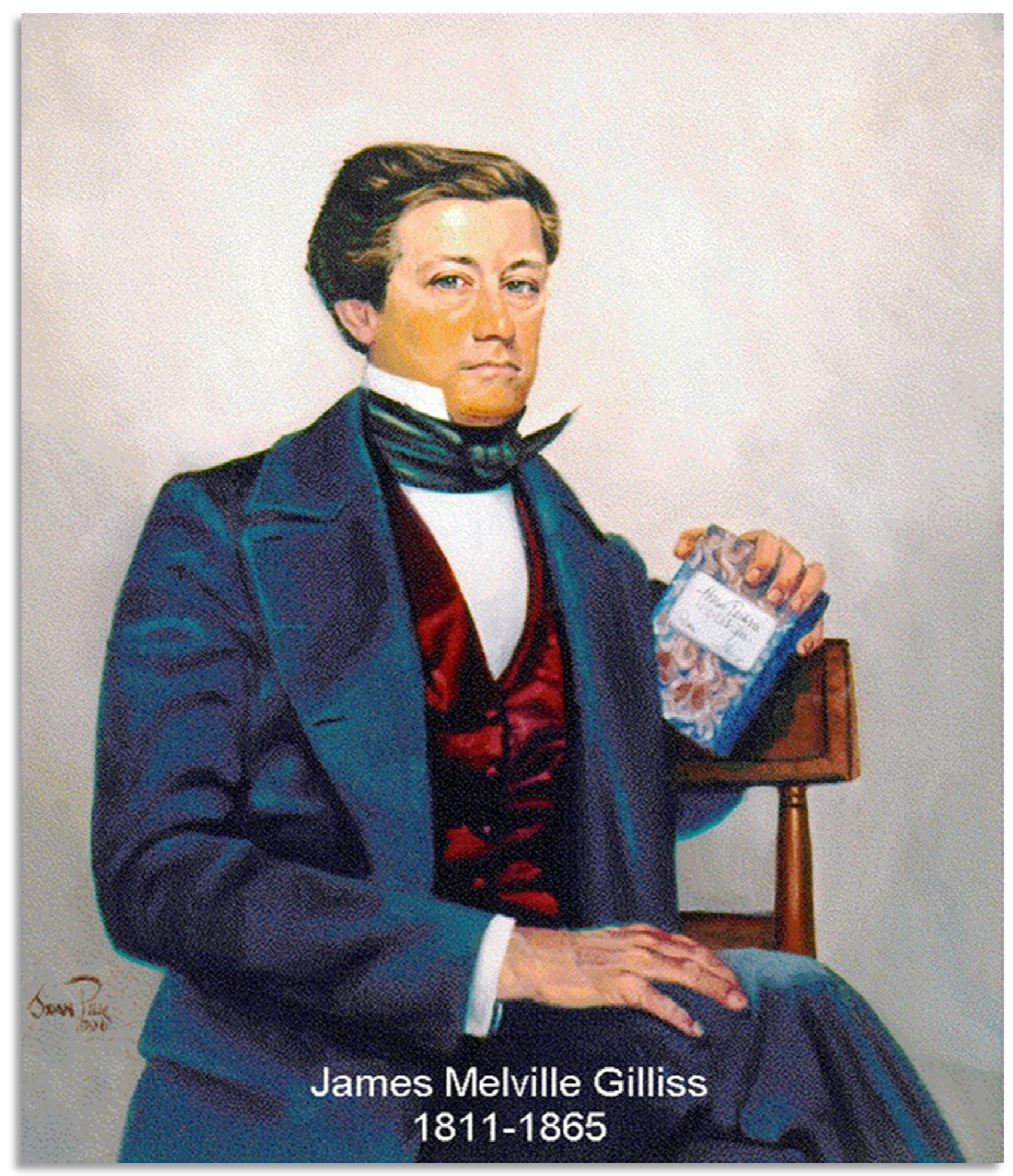

Pintura de James Melville Gilliss, por Beverly Stautz. ${ }^{3}$

De volta aos Estados Unidos, retornou à Marinha para trabalhar no Depot of Charts and Instruments ${ }^{4}$, criado em 1830 com a finalidade de manter todas as cartas náuticas, cronômetros, telescópios, livros e instrumentos náuticos, e também de oferecer suporte às atividades científicas realizadas pela arma norte-americana ${ }^{5}$. Quando Charles Wilkes, o primeiro encarregado do Depot, assumiu o comando da primeira expedição de circum-navegação científica do país, a U. S. Exploring Expedition, entre 1838 e 1842, ainda

\footnotetext{
${ }^{3}$ Imagem extraída do sítio: http://www.usno.navy.mil/USNO/library/images_library/Gilliss.jpg/view. Acesso em 10/02/2013.

${ }^{4}$ A partir desse momento, usarei o nome inteiro desta instituição dentro da Marinha, ou apenas o termo Depot.

${ }^{5}$ Cf: LEEMAN, op.cit., p.104.
} 
durante os preparativos para volta ao mundo, Gilliss foi promovido e ocupou o lugar de Wilkes no Depot em $1837 .{ }^{6}$ Foi nessa instituição, ainda que de maneira precária devido à carência de estrutura, que Gilliss realizou suas primeiras observações astronômicas com a finalidade de desenvolver estudos climáticos.

A partir deste ano, Gilliss dedicou mais tempo à Astronomia e observou uma extensa série de trânsitos da Lua e de culminações de estrelas, a fim de determinar longitudes para o mapeamento do rio Savannah, situado entre os estados da Carolina do Sul e Geórgia. No entanto, estas observações não chegaram a ser reduzidas, ou seja, tais observações não passaram pelo crivo científico que visava os procedimentos necessários para transformar um dado bruto observado num dado final constatado a ser utilizado em outras observações. ${ }^{7}$ Foi também neste ano que se casou com Rebecca Roberts, de Alexandria (atual Virginia), tendo com ela seis filhos.

Já com experiência no campo das medições astronômicas, Gould afirma que Gilliss colaborou, realizando observações para determinar as diferenças de longitude através das culminações lunares e eclipses, que também estavam sendo feitas pela equipe da já citada U.S Exploring Expedition (1838-1842), sob o comando do capitão Charles Wilkes. ${ }^{8}$ Foi a partir desse momento que Gilliss efetivamente iniciou sua carreira destacando-se como um dos primeiros norte-americanos a realizar observações sistemáticas e publicações no campo da Astronomia nos Estados Unidos. ${ }^{9}$ Aqui, vale mencionar que em 1838, ano em que a expedição de Wilkes lançou-se ao mar, Gilliss foi promovido a Lieutenant (capitão-tenente). Neste período, como já dito, as promoções eram feitas através de indicações, fato que gerou discussões no

\footnotetext{
${ }^{6}$ Cf: PONKO, op.cit., p. 93.

${ }^{7}$ GOULD, op.cit., p.139-140

${ }^{8}$ Sobre esta importante expedição, conferir a pesquisa: JUNQUEIRA, Mary Anne. Velas ao mar. U. S. Exploring Expedition (1838-1842). A viagem científica de circum-navegação dos norte-americanos. São Paulo: Intermeios, 2015.

${ }^{9}$ GOULD, op.cit., p.140-41.
} 
Congresso na década de 1840, quando alguns congressistas apontaram que esta forma de promoção era antidemocrática, pois aspirantes vindos das camadas médias da sociedade não competiam em igualdade com aqueles de camadas sociais mais altas. Para alcançar altas patentes, em geral, era necessário pertencer à camada social dos gentlemen, ambiente que possibilitava contatos com o alto comando da Marinha. ${ }^{10}$

Das colaborações com a expedição de Wilkes nasceu um volume especializado, intitulado: Astronomical observations made at the Naval Observatory, Washington, under orders of the honorable Secretary of the Navy, dated august 13, 1838. Esse volume continha a posição de 1248 estrelas e foi o primeiro catálogo do tipo publicado nos Estados Unidos. Neste período, foi gestada uma série de observações meteorológicas e magnéticas, que também foram publicadas em um volume, no ano de $1845 .{ }^{11}$

Entre 1841 e 1844, em paralelo as suas observações astronômicas, Gilliss se envolveu com a reforma do Depot e a construção do Observatório Astronômico de Washington, na capital do país, incluindo uma viagem para a Europa para a compra de equipamentos e bibliografia especializada.

De fevereiro de 1845 a julho de 1848, Gilliss permaneceu ocupado com a preparação de observações astronômicas feitas no Observatório para serem impressas e, ao fim deste trabalho, a ele foi atribuído o dever de realizar algumas reduções astronômicas, sob a orientação do professor Alexander Bache, importante astrônomo e superintendente da Coast Survey. ${ }^{12}$ Em paralelo, manteve correspondência com astrônomos europeus, trocando informações sobre pesquisas na área.

\footnotetext{
${ }^{10}$ Cf. LEEMAN, op.cit. pp.152-3.

${ }^{11} \mathrm{Cf}$ : GOULD, op.cit.

${ }^{12}$ O Coast Survey foi o centro oficial de cartografia dos Estados Unidos. Criado em 1807, concentrava matemáticos, cartógrafos entre outros especialistas na tarefa de mapear acuradamente a costa leste do país, e é uma das mais antigas organizações científicas do governo dos EUA. Em 1878, foi dado o nome de Coast and Geodetic Survey (C \& GS). Em 1970, tornou-se parte da National Oceanic and Atmospheric Administration (NOAA).
} 
No ano de 1848, após amadurecer a proposta que chegara a partir de um astrônomo germânico que lhe apresentou um novo método para se tentar obter medidas da paralaxe solar na América do Sul — fato que analisaremos adiante - Gilliss planejou uma expedição astronômica e para tanto, iniciaria uma peregrinação para obter apoio na Marinha, nas instituições científicas e no Governo Federal.

Gilliss foi membro das principais instituições científicas da época, tais como a American Philosophical Society (Estados Unidos), The Academies for promotion of the Natural Sciences at Philadelphia, entre outras, incluindo seus contatos com os principais membros do Smithsonian Institution, o grande museu dos Estados Unidos. Estas instituições são de grande importância neste período ao país, pois congregavam e articulavam politicamente os cientistas que buscavam reconhecimento e poder para atuar junto ao governo e este, por sua vez, usava de laudos e pesquisas dessas instituições e das Universidades para respaldar suas ações em diversos segmentos governamentais. ${ }^{13}$

Lembro novamente que a grande justificativa para que a expedição astronômica ocorresse voltou-se para a necessidade de precisão da localização em alto-mar, o que auxiliaria navios da Marinha de Guerra e Mercante em viagens de longo curso. ${ }^{14}$

O historiador-chefe da National Aeronautics and Space Administration (NASA), Steven Dick, aponta que o Congresso por vezes negou empreendimentos científicos e não tinha muito interesse em promover a ciência, exceto no assunto de patentes e, posteriormente, quando esta favorecia o desenvolvimento do país, como no caso do aprimoramento das

\footnotetext{
${ }^{13}$ Sobre a relação entre ações governamentais e as universidades, Cf: SALVATORE, Ricardo D. Imágenes de un imperio. Estados Unidos y las formas de representación de América Latina. Buenos Aires: Editorial Sudamericana, 2006. Ver também: DUPREE, Hunter A. The national pattern of American learned societies, 1769-1863. In: OLEOSON, Alexandra, BROWN, Sanborn (Org.) The pursuit of knowledge in the early American republic. American scientific and learned societies from colonial times to the Civil War. Baltimore: John Hopkins University Press, 1976.

${ }^{14}$ Sobre a questão das longitudes, Cf: ANDREWES, William (Org.) The Quest for longitude. The proceedings of the longitude symposium Harvard University. Cambridge,MA: Harvard University Press,1996. Ver também: DICK, Steven. "Centralizing navigational technology in America: The U. S. Naval Depot of Charts and Instruments, 1830-1842". Technology and Culture. Baltimore, v.33, Jul, 1992.
} 
medidas de localização em alto-mar. Muitas vezes a justificativa se dava com base na Constituição, que não previa este tipo de apoio. Outras vezes, a recusa ou atraso em aprovar demandas científicas se devia a desafetos políticos dos solicitantes, ou mesmo na contenção de gastos. ${ }^{15} \mathrm{O}$ fato é que a ciência, até a década de 1830, não era um tema relevante para o governo dos Estados Unidos. No entanto, o era para as instituições científicas norte-americanas muito antes do século XIX. Um exemplo é o interesse da American Philosophical Society em observar o Trânsito de Vênus em 1769, cujas observações e cálculos foram feitos pelo astrônomo e matemático David Rittenhouse. $^{16}$

De 1849 a 1852, Gilliss realizou e comandou a expedição Astronômica ao Chile. Ao retornar após quase quatro anos de exploração no Chile, iniciou os trabalhos de redução das observações astronômicas realizadas durante a viagem e da preparação dos relatórios da expedição, os quais justificariam os gastos feitos pelo Governo dos Estados Unidos.

James Melville Gilliss continuou a participar de expedições científicas após a viagem que estudo. Em 1858, ao receber a notícia de que astrônomos europeus estariam viajando ao Brasil para observar um eclipse solar, Gilliss conseguiu permissão para viajar ao Peru a fim de poder, assim como os europeus, realizar suas observações. Gilliss também participou de outra expedição, em 1860, com o objetivo de observar outro eclipse solar. Esta viagem contou com a participação de diversos cientistas norte-americanos que se locomoveram para diferentes locais no interior dos Estados Unidos.

Com relação à expedição de 1858 ao Peru, é interessante atentar novamente para a biografia de Gould, que nos informa sobre a cooperação de vários agentes internacionais para tornar possível a viagem: a United States Mail Steamship Company, a Panama Railroad Company, e a Pacific Mail

\footnotetext{
${ }^{15}$ Cf: DICK, Steven J. Sky and Ocean Joined: The U.S. Naval Observatory - 1830-2000. Cambridge: Cambridge University Press, 2003.

${ }^{16}$ Cf: http://www.apsmuseum.org/tov-event/. Acesso em 22/10/2014.
} 
Steamship Company, ofereceram assistência para realizar o empreendimento. A British Steam-Navigation Company garantiu transporte gratuito e instruiu seus agentes a ajudar a transportar os objetos da expedição de todas as formas possíveis. Além disso, o capitão de um navio francês (nome não divulgado) se ofereceu para colaborar, e de fato o fez, já que, ao perceber que seria necessário se aproximar dos Andes para realizar as observações, Gilliss deixou com ele um cronômetro e um telescópio-zênite para que se deslocasse 60 milhas ao sul de Payta, no Peru, local onde seria viável a observação do eclipse solar. ${ }^{17}$

Com a eclosão da Guerra de Secessão (1861-1865), o Comandante Mattew F. Maury deixou seu cargo de Superintendente no Observatório Naval e posicionou-se ao lado dos Confederados. Gilliss então foi convidado a assumir o posto desejado por ele há anos. Assim, em 1861, durante a Guerra Civil ele foi responsável em fornecer instrumentos e cartas navais aos navios dos nortistas.

Gilliss morreu em 9 de fevereiro de 1865, aos 53 anos de idade, no auge de suas pesquisas astronômicas. Sobre a vida pessoal do autor, pouco se sabe. Durante a pesquisa, verificou-se que em geral as citações sobre ele usam como fonte a mesma usada nesta pesquisa, qual seja, a apresentação feita por Benjamin A. Gould, uma espécie de memória biográfica, rendendo homenagem ao Capitão para a National Academy of Sciences dos EUA em 1866, um ano após a sua morte. No entanto, os relatórios de viagem de Gilliss nos deixam algumas pistas. Veremos que, como esperado, ele considerava os norte-americanos letrados, pertencentes à elite do país, como superiores aos demais. Para os grupos humanos dos países sul-americanos que visitou, em geral, se referiu com preconceito e os condenou como atrasados. Para determinadas regiões, predominou o interesse geopolítico e comercial. E para o céu, o seu interesse predileto: o de um astrônomo norte-americano

\footnotetext{
${ }^{17}$ Cf. GOULD, op.cit. p.173.
} 
determinado a colocar os Estados Unidos na rota dos cientistas astrônomos de destaque e respeito, que estariam ao lado ou, um dia, preferencialmente à frente dos demais.

\section{1 - Archibald MacRae — o viajante dos Andes}

Além de Gilliss, outro oficial que compunha a equipe que realizou a expedição, Archibald MacRae, também contribuiu com a escrita do relatório e consequentemente, na construção de imagens e representações sobre a América do Sul. Designado por Gilliss para permanecer na América do Sul ao término dos trabalhos no Chile, ele percorreu a região dos Andes, na Argentina, com o objetivo de realizar algumas medições relacionadas à Astronomia, ao Magnetismo, à Geografia e à Meteorologia da região. As descrições sobre aspectos políticos e culturais também foram determinadas por Gilliss em suas instruções à MacRae:

Qualquer informação que puder coletar a respeito dos povoados pelos quais você passar; seus recursos, tantos os da agricultura como os minerais; suas manufaturas e comércio com outras cidades da república; o número de nascimentos e mortes; as condições morais, doenças e crimes — darão interesse adicional ao seu relatório. $^{18}$

Vemos uma vez mais que Gilliss, mesmo focado nos objetivos científicos da expedição, não deixou de instruir seu oficial para que recolhesse dados que interessavam aos Estados Unidos. Como veremos no último capítulo desta tese, MacRae obedeceu parcialmente às ordens de Gilliss e escreveu um relatório bastante destoante no que se refere aos dispositivos

\footnotetext{
${ }^{18}$ GILLISS, op.cit., Vl 3, p. XLII. No original: Anny information you can collect respecting the populations trough which you pass; their resources, both agricultural and mineral; their manufactures and commerce with other towns of the republic; the number of births and deaths; the condition of morals, diseases, and crimes - all will give additional interest to your report.
} 
discursivos utilizados e a escolha dos elementos para construir as representações de países e povos da América do Sul.

Os relatórios de viagens científicas seguiam um modelo nos quais se reuniam informações científicas em determinados volumes e descrições sobre a região, nem sempre livre de julgamentos que opunham os Estados Unidos em relação aos lugares visitados. O referencial de modelo de civilização para James Gilliss, como esperado, era o de seu próprio país. Assim, os povos visitados muitas vezes se transformaram no "outro" a ser, com frequência, julgado de forma preconcebida.

O oficial partiu de Santiago para Mendoza, passando por San Luis de la Punta e Rosario; de lá, passou por Montevidéu e se dirigiu a Buenos Aires, de onde retornou para os Estados Unidos. Ou seja, ele atravessou da costa Oeste da América do Sul, no Pacífico, para a costa Leste, no Atlântico, por terra.

Infelizmente houve contratempos na viagem. Um de seus principais instrumentos, o barômetro, quebrou, e seus cronômetros também se mostraram desregulados, fato que o levou a retornar à região à custa própria e refazer o itinerário. Assim, pouco depois de retornar aos Estados Unidos, MacRae embarcou novamente para Buenos Aires e, de lá, refez o seu trajeto, desta vez em sentido contrário, até chegar ao Chile. Seu relatório foi entregue a Gilliss e incorporado ao volume dois.

MacRae, assim como Gilliss, relatou sua experiência, tecendo comentários bastante abrangentes sobre as regiões por onde passou, aos quais, como vimos na introdução, nos demoraremos em um capítulo específico sobre esta parte do relatório da expedição.

\section{2 - A profissionalização da U.S. Navy}

Gilliss, como vimos, construiu sua carreira astronômica dentro e a serviço da Marinha de guerra norte-americana, instituição que devido a suas 
demandas específicas, favoreceu o florescimento de alguns campos da ciência. Procuremos, então, compreendê-la.

Criada em 1794, a U.S Navy esteve à frente da proteção do país, tanto em tempos de guerra, como em tempos de paz. Da forte preparação para guerras e contenção de navios piratas, ao mapeamento dos mares a fim de garantir a circulação de embarcações e assim favorecer o desenvolvimento econômico do país, a ciência, de uma forma ou de outra, esteve relacionada a este processo, pois para navegar de forma mais segura, era preciso aprimorar as cartas marítimas e para se destacar neste e em outros aspectos, era preciso dominar determinados saberes, tal como as grandes nações que imperaram no século XIX.

No entanto, de acordo com William Leeman, a história da Marinha norte-americana enfrentou altos e baixos, havendo períodos, como na década de 1820 , em que esteve em declínio. ${ }^{19}$ Foi a partir do investimento na formação acadêmica de seu corpo de oficiais na década de 1830 e principalmente na de 1840 , bem como em inovação tecnológica, que a Marinha ganhou novamente um lugar de destaque. Neste período foram feitas reformas importantes que resultaram na modernização e ampliação da formação de seus contingentes, que envolvia não apenas o conhecimento sobre a manutenção de um navio, mas saberes científicos, além de incentivar a formação de oficiais hábeis em identificar locais com potencial geopolítico e campos comerciais e diplomáticos para o país. Esse impulso reformista reconfigurou a Marinha e tornou viável a execução eficiente das funções dos oficiais ao representar os interesses da U.S. Navy e do país.

Assim, a Marinha, principalmente a partir de 1840, não deveria estar preparada apenas para vencer batalhas, mas também para negociar tratados, expandir o comércio de seu país, explorar novas terras, conduzir pesquisas científicas e publicar livros e artigos.

\footnotetext{
${ }^{19}$ Cf. LEEMAN, op. cit. p.130-4.
} 
Até meados de 1840, Leeman destaca a importância do Naval Lyceum de Nova York e da criação da academia de West Point (1802), como centros formadores de oficiais. ${ }^{20}$ Neste último caso, lembremos que a formação oferecida era para os oficiais do exército. Para além da aprendizagem específica, prezava-se desde tempos remotos por uma formação que lhes habilitasse a serem homens cultos, verdadeiros gentlemen, abrindo-lhes as portas da alta sociedade dentro e fora do país. Mary Junqueira aponta, ao analisar a vida de oficiais, marinheiros e cientistas no interior dos navios, para a necessidade de um oficial que pretendia alcançar novas patentes de dominar diversos temas, os quais eram testados à mesa, dentro das embarcações, em jantares com o Capitão. Esperava-se que os oficiais fossem capazes de versar sobre os mais variados assuntos, de Ciências à Literatura. ${ }^{21}$ Esta exigência permaneceu após as reformas da Marinha.

Tal formação explica em parte o refinamento e o elitismo que encontramos em Gilliss e seu julgamento preconceituoso diante das sociedades sul-americanas, embora ele tenha se formado antes da modernização da U.S. Navy. Seu percurso inicial foi como aprendiz a bordo de navios e nas funções exercidas em alto-mar. No entanto, sua passagem pela universidade e sua formação em Astronomia, que se deu na França, constituem indicativos de seu vínculo com a nova Marinha e com um grupo de cientistas que primava pela formação acadêmica, além de seu pertencimento a uma elite norte-americana, que apresentava e valorizava, de forma geral, esse mesmo refinamento e olhar estigmatizado sobre os "outros lugares".

Durante a segunda metade da década de 1830, no impulso reformista promovido por oficiais dentro da Marinha, foram publicados os conhecimentos científicos e também específicos produzidos por esta

\footnotetext{
${ }^{21}$ Cf. JUNQUEIRA, Mary, op.cit. p.130.
} 
instituição. Além de informar sobre promoções, aposentadorias, obituários, viagens, artigos reformistas em prol de melhorias, etc., muitas publicações buscavam apoio para as reformas necessárias e pela valorização dos oficiais. Dentre os meios de comunicação, destaco o jornal Naval Magazine, publicado entre 1836 e 1837. Como já sugeri, Gilliss acompanhou o movimento de reforma na educação dos oficiais, e certamente simpatizava com tais propostas, que envolviam o estudo de Ciências matemáticas, Astronomia, Literatura, Línguas, Engenharia, entre outras.

\subsection{1 - Atuação de Gilliss junto ao Depot of Charts and Instruments e o Observatório Astronômico}

A princípio, os pedidos de autorização para viagens e expedições eram feitos pelo Secretário da Marinha, e depois, conforme o caso, levados ao Congresso para aprovação. Até 1849, o Secretário da Marinha era membro integrante do Gabinete Presidencial e chefe do Departamento da Marinha, dentro do Departamento de Defesa dos Estados Unidos. Seu apoio, portanto, era fundamental para tornar viável uma expedição como a de Gilliss.

Segundo Ponko, em 1841, foi Gilliss quem reportou ao Conselho Naval que a estrutura existente no Depot of Charts and Instruments para a pesquisa astronômica era inadequada. Este Conselho levou o relatório até o Secretário da Marinha, James K. Paulding, já em final de mandato, relatando a necessidade de investimentos junto ao Depot. Paulding, por sua vez, o subscreveu e encaminhou ao presidente, que recomendou sua aprovação junto ao Congresso ${ }^{22}$.

O Congresso então legislou o projeto que visava à reforma do Depot e a construção de um Observatório Astronômico. Nesse momento, o Secretário da Marinha já era Abel Upshur, sulista que se tornou conhecido como grande reformador da Marinha e sobre o qual nos demoraremos adiante. No entanto,

${ }^{22}$ PONKO, op.cit, p.94 
aqui, saliento que secretários como ele, assim como alguns membros do Congresso e das sociedades científicas norte-americanas já desejavam, ainda na primeira metade do século XIX, equiparar a Marinha do país às das potências europeias, no desenvolvimento da ciência e no poder da arma.

Com a aprovação e recebimento dos fundos para iniciar a reforma do Depot e a construção de um Observatório astronômico nos Estados Unidos, Gilliss - o mentor do projeto - ficou encarregado de supervisionar a construção e de viajar à Europa para realizar a compra de instrumentos e de novos livros. De acordo com Dick, Gilliss foi autorizado a gastar vinte e cinco mil dólares em instrumentos e livros ${ }^{23}$. Segundo este autor, seguindo os passos de outros cientistas renomados dos Estados Unidos, Gilliss deu preferência aos instrumentos germânicos, os quais eram fabricados em Munique e em maior volume e qualidade que os produzidos no Reino Unido. ${ }^{24}$ Para tanto, fez contato com astrônomos europeus durante a viagem, a fim de certificar-se de estar obtendo os instrumentos adequados e de trocar informações e consolidar redes de contatos com cientistas europeus, especialmente os germânicos.

Em março de 1843, ele voltou para os Estados Unidos. Em dezoito meses o edifício foi construído e os instrumentos comprados na Europa foram transportados e, assim, montado o Observatório. Além disso, ele formou uma pequena biblioteca com os livros que adquiriu. Em setembro de 1844, o

\footnotetext{
${ }^{23}$ É bastante complexo estimar a quantia de $\$ 25.000$ para os dias atuais. Não há consenso entre economistas e historiadores sobre as fórmulas e os métodos de conversão de valores. Para empreendimentos de larga escala, como a construção de observatórios e expedições científicas, julgamos vantajoso comparar o custo relativo, a partir do índice de custos de toda a produção econômica (PIB), e não a partir de um índice de preços relativo a uma cesta básica. Isso porque uma iniciativa como esta empregava diversos equipamentos, materiais da construção civil e mão-de-obra (especializada ou não) - mobilizando, portanto, vários setores da economia. O deflator do PIB, que reflete a média de preços da economia em um período, será, portanto, utilizado na maior parte das conversões da pesquisa. Nos Estados Unidos, o PIB só começou a ser calculado a partir de 1929, por conta da crise; portanto, os dados de anos anteriores são baseados em estimativas e estudos de historiadores econômicos. Feita as ressalvas, $\$ 25.000$ correspondiam, grosso modo, a cerca de $\$ 572.000$ atualmente (2014). Cf. JOHNSTON, Louis; WILLIAMSON, Samuel. Sources and Techniques Used in the Construction of Annual GDP, 1790-2014.

Disponível em: <http://www.measuringworth.com/usgdp/sourcegdp.php>. Acesso em: 20/10/2015.

${ }^{24}$ Cf: DICK, op.cit.,p.64.
} 
Observatório estava pronto para ser inaugurado com o nome de United States Naval Observatory.

No entanto, para a surpresa de Gilliss e de muitos de seus colegas de Instituições científicas, ele não foi o escolhido para ser o superintendente do Observatório que lutara para construir. O tenente que assumiu o posto foi Matthew Fountaine Maury, sulista e oficial da Marinha desde 1825. Defensor feroz da reforma na Marinha norte-americana, Maury defendia publicamente a necessidade de aquisição de navios a vapor, do desenvolvimento do comércio com os países localizados no Pacífico, além da melhoria do sistema de promoção de oficiais para estimular a sua ambição. Também propunha a fundação de uma academia naval que oferecesse formação de quatro anos, seguido de dois anos no mar, para substituir o sistema, no qual a maior parte da formação se dava a partir da experiência a bordo dos navios. ${ }^{25}$

De acordo com Leeman, a forte liderança de Maury tornou possível a criação, em 1845, da Escola Naval em Annapolis, fato que lhe rendeu o título de "Pai da Academia Naval". Maury publicou uma série de artigos usando pseudônimos, defendendo a reforma. Após ser identificada sua autoria, obteve grande prestígio por parte dos oficiais. Sua liderança nesse projeto reformista da Marinha, seus contatos e fortes laços políticos entre os oficiais sulistas no alto escalão, além de sua bagagem científica, tornaram Maury — e não Gilliss - o homem escolhido para assumir o cargo de Superintendente do Observatório Naval. ${ }^{26}$

Embora Maury não circulasse com a mesma intensidade que Gilliss entre as instituições científicas norte-americanas, tinha estreitas ligações com o atual Secretário da Marinha e com os anteriores, especialmente com o já citado Abel Upshur, Secretário durante o período de construção do

\footnotetext{
${ }^{25}$ Cf. GOLD, op.cit., p.64.

${ }^{26}$ Cf: Leeman, op.cit., p.149.
} 
Observatório e reforma do Depot. ${ }^{27}$ Ademais, Maury era um cientista que realizava importantes pesquisas no campo da Hidrografia. ${ }^{28}$ Aqui, vemos claramente que a aptidão e os laços políticos de Maury contaram pontos a seu favor, a despeito da experiência e dedicação de Gilliss junto ao Depot e no campo da Astronomia.

Isso não significa que Gilliss não buscou inserir-se no grupo dos "eleitos" entre os oficiais de alto escalão da Marinha, já que notamos sua intensa colaboração com Upshur no esforço de modernizar a instituição. Como vimos, foi dele o relatório pedindo pela reforma do Depot e pela construção do Observatório Naval. Gilliss partilhava, portanto, dos interesses dos líderes da Marinha e buscou colaborar com os mesmos. Mas as indicações são de que essas relações eram profissionais, e perderam força diante de um oponente de peso que partilhava também da amizade dessas lideranças.

Gilliss, por sua vez, tinha a seu lado grandes nomes das instituições científicas do país. Veremos adiante que esses cientistas ligados a Gilliss tomaram posição de incentivo à expedição astronômica ao Chile, proposta por ele, junto ao Congresso.

Podemos assim concluir que, para o crescimento dentro da U.S Navy, não bastava a Gilliss seu comprometimento com a Astronomia. Ainda assim, ele permaneceu trabalhando em suas observações e estreitando laços não com os políticos do Congresso e Secretários da Marinha, mas com um grupo específico de cientistas que delinearam o formato das pesquisas na área das ciências nos anos que viriam e criaram uma instituição científica ligada ao governo e por ele mantida, a qual trataremos adiante.

Gilliss desejava instrumentalizar a Marinha com o conhecimento científico que poderia ser obtido a partir de observações astronômicas e da troca entre o governo e as instituições científicas nacionais e internacionais.

\footnotetext{
${ }^{27} \mathrm{Cf}$ : HALL, Claude H. "Abel P. Upshur and the Navy as an Instrument of Foreign Policy". The Virginia Magazine of History and Biography.Vol.69, No. 3 (Jul., 1961), pp. 290-299.

${ }^{28}$ Cf: http://www.navy.mil/submit/display.asp?story_id=9440. Site visitado em 22/05/2014.
} 
Sua ambição era patente, bastando para isso observar seus esforços para iniciar observações astronômicas em um ambiente inicialmente precário e, posteriormente, com a sua imersão no objetivo de dar vida ao Observatório.

Apesar de Gilliss ter perdido essa batalha, ao que tudo indica, a perda do cargo o aproximou ainda mais de alguns importantes cientistas norteamericanos em busca da promoção da ciência em seu país.

\subsection{2 - Abel Upshur e as reformas da U.S. Navy: ciência e tecnologia a serviço dos interesses nacionais}

No período marcado pelo início das reformas na U.S. Navy e da determinada entrada de Maury no campo, esteve à frente da Marinha o reformador Abel Upshur, sulista da Virgínia, que esteve no comando como Secretário da Marinha entre outubro de 1841 e julho de 1843. Neste período, vimos que Gilliss já atuava fortemente no campo da Astronomia e Meteorologia no Departamento.

De posição política conservadora e pró-escravidão, recebeu inicialmente grande hostilidade e desconfiança por parte de alguns jornalistas e de alguns políticos, pois se temia que a escolha de Upshur pelo presidente fosse arriscada, já que ele era conhecido por ter escrito que a separação entre Norte e Sul era constitucional. Assim, no caso de uma guerra entre nortistas e sulistas, ele poderia usar dos conhecimentos adquiridos no cargo para obter vantagem defensiva. ${ }^{29}$ Notemos que essa discussão já estava em pauta na década de 1840, muito antes da eclosão da Guerra Civil americana, ocorrida entre 1861-65.

No entanto, em menos de um ano e meio, Upshur conquistou renome nacional como competente reformador, colocando a Marinha norte-americana em um novo patamar. Ele conseguiu convencer o Congresso de que era necessário investir na arma para adquirir segurança nacional efetiva.

\footnotetext{
${ }^{29}$ Cf. LEEMAN, op.cit., p. 149.
} 
Trabalhou de forma incansável na busca de seus objetivos, obtendo êxito em vários de seus pedidos, criando departamentos (bureau) dentro do Depot e modernizando a frota de navios.

Sua administração eficiente lhe rendeu o cargo de Secretário do Estado em janeiro de 1844. Ao longo de seus primeiros meses como Secretário da Marinha, ia ao Depot diariamente e realizava reuniões com os membros do Conselho Naval, com o Coronel Archibald Henderson, Comandante do Corpo de Fuzileiros Navais, com o Capitão Beverley Kennon e com o Tenente Matthew Fontaine Maury, todos velhos amigos pessoais de Upshur.

Em dezembro de 1841, apresentou um relatório ao Congresso que trouxe prestígio e o fim da resistência que enfrentou no início de suas funções. Esse relatório propunha numerosas reformas para viabilizar a construção de uma Marinha eficiente, que ele acreditava que poderia ser usada como um instrumento de política externa dos Estados Unidos. As primeiras propostas de Upshur apresentavam uma reorganização completa da Marinha. Um projeto de lei - elaborado pelo próprio Secretário - foi submetido ao Comitê da Câmara sobre Assuntos Navais no início de 1842. A reorganização foi projetada para permitir ao Secretário exercer uma supervisão mais vigilante e inteligente sobre todas as operações navais, sem sobrecarregá-lo com detalhes pequenos.

Depois de meses de debate, o Congresso autorizou apenas uma reorganização parcial da administração naval. Assim, o Conselho de Comissários da Marinha foi abolido, e em seu lugar cinco agências foram criadas, cada uma dirigida por um capitão e respondendo diretamente ao Secretário. Nascia o Bureau of Yards and Docks; o Bureau de Construção, Reparos e Equipamentos; o Bureau de Material Bélico e Hidrografia; o Bureau de Provisões e Vestuário e o Bureau de Medicina e Cirurgia. Vemos 
aqui que a Marinha inicia seu processo de profissionalização, a fim de tornála mais eficiente e administrável. ${ }^{30}$

Outra recomendação importante foi menos popular, especialmente na Câmara. Upshur pediu um aumento imediato de recursos para a Marinha com o objetivo de torná-la uma força com a metade do tamanho da grande Marinha da Grã-Bretanha. Isso exigiria um aumento das dotações navais de quase cinquenta por cento sobre o ano anterior. Ele insistiu que nada havia sido pedido além do necessário, e afirmava que não seria conivente em poupar quando isso significava colocar o país em uma condição precária diante de ataques.

Durante o mandato de Upshur, várias fragatas de primeira classe, uma delas em construção há quase 20 anos, foram concluídas em 1843, além do início da construção de seis saveiros. A construção de alguns novos navios, no entanto, pode ser considerada experimental. Upshur acreditava que uma grande parte da frota deveria ser a vapor, como dito, e que os experimentos deveriam ser realizados com cascos de ferro, um importante recurso natural, de valor acessível e "quase indestrutível". Assim, o Congresso aprovou a produção de um navio com essas características - o primeiro da Marinha que foi concluído em 1844. Vemos aqui novamente a busca pelos Estados Unidos em equiparar sua Marinha a das grandes potências europeias, além da aposta em inovar partindo de novas tecnologias. No entanto, essa ambição não pode ser considerada como unânime entre os políticos, já que muitos consideravam desnecessárias quaisquer demonstrações de força em tempos de paz. Nesse momento, o que se nota é um movimento com focos dentro do governo, em suas diversas instituições, como no caso da Marinha, que já se posicionava a favor dessa equiparação. Por outro lado, vale lembrar o quanto essas inovações foram úteis pouco tempo depois, na Guerra com o México (1846-1848), cuja modernização da Marinha de Guerra exerceu impacto

${ }^{30}$ Cf. LEEMAN, op.cit., p. 152 . 
importante e levou à vitória norte-americana, principalmente na tomada da Califórnia.

Para se ter uma ideia do interesse em inovar, o navio Princeton foi o primeiro navio de guerra de seu tipo no mundo. Produto do engenheiro John Ericsson, um sueco que a convite da U.S. Navy, construiu um dos navios de guerra mais avançados do seu tempo, equipado com uma hélice de parafuso em vez de rodas laterais, e com a maquinaria abaixo da linha da água.

Em seu ímpeto modernizador, Upshur foi muitas vezes contestado por muitos dos oficiais mais velhos da Marinha que se opuseram a mudanças estruturais em curso. Eles não gostavam de ver os navios antigos a vela perecer, e ressentiram-se com a transformação da antiga frota em navios a vapor. Aqui, vemos que parte da Marinha resistia e mesmo desconfiava das novas tecnologias, fenômeno que pode ser encontrado em vários segmentos da indústria e no pensamento de parte da população, que defendia um modo de vida simples. Naquele país, como acabamos de afirmar, também havia resistência por parte de muitos navegadores em utilizar os barcos a vapor. Muitos acreditavam que embarcações a vela tinham o seu valor justamente por depender da habilidade de quem as guiava, enquanto a nova tecnologia tirava das mãos do capitão esse poder. Upshur alegava que para o desenvolvimento de navios a vapor eram necessários oficiais que possuíssem um maior conhecimento técnico e científico. ${ }^{31}$

Upshur forneceu a liderança civil indispensável na fase inicial da revolução técnica naval então em curso. Como já dito, nem todas as reformas propostas pelo Secretário foram realizadas, e muitos homens do Congresso a encararam como absurdas. Entre as que foram rejeitadas, podemos citar os seus pedidos para a criação de postos de Almirante, Vice-almirante, e Contraalmirante para dar aos oficiais norte-americanos a proporcional classificação com os seus comandos e igualdade de postos comparados com os de oficiais

\footnotetext{
${ }^{31}$ Cf. LEEMAN, op.cit. p.151.
} 
de outros países ${ }^{32}$; a criação de uma academia naval; bases navais adicionais, incluindo uma nas Ilhas Sandwich (hoje Havaí); aumento substancial na força do Corpo de Fuzileiros Navais, melhores salários e condições aos oficiais da Marinha. A maioria desses pedidos foi negada sob o argumento de falta de verbas. No entanto, no que se refere à criação de novas patentes na Marinha, os congressistas negaram por considerar desnecessário criar postos já supridos pelos oficiais que ocupavam as patentes já existentes, embora possamos aferir que a negativa para novas patentes na Marinha se deva à rejeição em criar postos que se assemelhassem às "hierarquias monárquicas", como afirma Mary Junqueira ${ }^{33}$. De acordo com Leeman, a argumentação de muitos oficiais era a de que a uniformização de patentes era necessária, já que muitos oficiais de tropas estrangeiras, com o título de Almirantes, por exemplo, se recusavam a aceitar ordens ou negociar com Capitães norte-americanos, por considerar estes como inferiores dentro do sistema hierárquico naval. Upshur também alegava que havia contradições dentro do próprio sistema interno de hierarquias entre os oficiais da defesa norte-americanos, já que a Marinha de Guerra possuía cerca de metade das patentes oficiais, se comparada às do exército americano (U.S. Army). ${ }^{34}$

No cômputo geral, é claro que durante o seu mandato, os Estados Unidos conquistaram uma crescente força naval que poderia ser usada para a defesa de possíveis ameaças e a outros interesses nacionais, particularmente os comerciais.

A expedição astronômica ao Chile ocorreu, então, em momento de modernização da U.S. Navy e sob a batuta dos sulistas. Gilliss, como vimos, nasceu em Washington, a capital dos nortistas durante a Guerra Civil. Ainda

\footnotetext{
${ }^{32}$ Cf: LEEMAN, op.cit. p.151.

${ }^{33}$ Mary Anne Junqueira afirma que "nas primeiras décadas do XIX, os homens da jovem república consideravam o almirantado demasiadamente vinculado à Monarquia. Os altos postos da Marinha de guerra eram ocupados por 'capitães sêniors'. Assim mesmo, alguns deles receberam o título de comodoro." Mary afirma também que o posto de Almirante só foi criado em 1862. Cf: JUNQUEIRA, op.cit., p.287.

${ }^{34}$ Cf: LEEMAN, op.cit., p.151.
} 
que fosse letrado, sofisticado, pertencente ao segmento mais alto da sociedade norte-americana, é possível também que Gilliss tenha sido rechaçado no comando do Observatório Astronômico por não pertencer a este grupo.

A construção do Observatório, a própria viagem científica ao Chile, o aumento da frota apontam para a constituição da U.S. Navy como arma moderna, de um país que pretendia se colocar no mundo como potente e ofensivo, mesmo em tempos de paz. Nesse sentido, ainda que Gilliss não tenha conseguido cargos de comando dentro da instituição, sua expedição é devedora e ao mesmo tempo reflexo desse impulso modernizador vivenciado na Marinha norte-americana do final dos anos 1840.

\section{3 - A U.S. Naval Astronomical Expedition e o contexto norte- americano: razões e justificativas para o empreendimento}

Entre o planejamento e aprovação da expedição até sua conclusão e impressão dos relatórios, três presidentes passaram pelo comando dos Estados Unidos: James K. Polk (1845-1849), Zachary Taylor (1849-1850) e Millard Fillmore (1850-1853). Os três presidentes, de um modo ou de outro, estiveram engajados na Conquista do Oeste que arrastou as fronteiras do país do Apalaches ao Pacífico.

A expedição de Gilliss ocorreu durante o mandato do Secretário da Marinha William B. Preston (1849-1850), sulista da Virgínia que seguiu a maré modernizadora dos secretários anteriores e cujo período demandou especial atenção de sua parte ao processo de expansão e anexação da Califórnia aos Estados Unidos. Além disso, precisava garantir a segurança e expansão do comércio no Oceano Pacífico, além de levar expedições da Marinha às águas chinesas, e em seguida, ao Japão, com o intuito de fortalecer as relações comerciais. A expedição ocorreu um ano após a Guerra com o México (1846-48) e indica as pretensões norte-americanas de mapear o 
território recém-conquistado. O difícil itinerário de Gilliss via Panamá aponta o interesse norte-americano em conhecer melhor a região.

A preparação da expedição astronômica impressiona se atentarmos para as condições do país na época. Em 1848, os Estados Unidos estavam independentes há setenta e dois anos, e acabavam de sair, como indicado, de uma guerra contra o México no qual o país latino-americano perdeu metade do seu território. Eram, portanto, uma jovem república ainda preocupada em consolidar seu Estado nacional.

Outro acontecimento importante nesse momento foi a corrida do ouro na Califórnia (1848-55), exatamente no período em que a expedição iniciou. Partindo dessas constatações, o percurso de Gilliss via Panamá pode indiciar o interesse em conhecer a região, cujo Istmo representava enorme potencial para facilitar o acesso à Califórnia. A busca por segurança em mar (principalmente pela obtenção de longitudes mais precisas) e por maior conhecimento dos países da América do Sul para fins comerciais e de consolidação de sua influência na região, estão relacionadas à aprovação da expedição. Isso explica os propósitos norte-americanos em levar a cabo uma expedição astronômica, quando estavam preocupados, sobretudo, com a consolidação e expansão territorial que conformaria o mapa político do país.

Acredito que, embora os norte-americanos fossem ainda um país em busca da consolidação do Estado nacional, a aprovação da expedição pelo Congresso do país também revela sua preocupação em conquistar um lugar de destaque no cenário internacional, não apenas por meios políticos e comerciais, mas buscando também inserir-se e destacar-se no campo da ciência e da técnica.

Considero, portanto, que - como afirmou Mary Junqueira sobre a circum-navegação da U. S. Exploring Expedition (1838-1842) — a aprovação pelo Congresso da expedição astronômica indica, na mesma direção, que os 
norte-americanos procuravam competir com os europeus. ${ }^{35}$ Como já dito, o Trânsito de Vênus foi um evento que mobilizou astrônomos do mundo todo, e a intenção dos homens da ciência nos Estados Unidos, como vimos, era dar um passo à frente dos europeus e conseguir êxito total nas observações que estavam por vir. No entanto, ainda que os congressistas considerassem as ambições acima citadas como ganho importante ao país, o prestígio, os benefícios comerciais que seriam obtidos a partir do aprimoramento do estabelecimento de longitudes e o lugar de respeito alcançado, provavelmente interessava mais do que avanço científico propriamente dito.

\footnotetext{
${ }^{35}$ JUNQUEIRA, Mary Anne. Op. Cit., 2015.
} 


\section{Capítulo II - James Melville Gilliss e a Expedição Astronômica: Alianças e disputas político-científicas nos Estados Unidos}

Durante o processo investigativo sobre as redes de contato científicas as quais Gilliss pertencia, deparei-me com uma instigante descoberta, que muito nos informa sobre os interesses de determinado grupo e sobre os embates científicos ocorridos nos Estados Unidos do fim da primeira metade do século XIX. Aqui, além de tratar das disputas do mundo acadêmico e dos seus vínculos com o universo militar da U. S. Navy, discuto a inserção dos Estados Unidos em meio às redes internacionais de conhecimento - em particular de países europeus - em torno de temas de interesse comuns.

\section{1 - The Lazaronni scientists: em nome de uma ciência acadêmica e em} busca de poder político

Ao investigar os nomes citados por Gilliss, tanto no apoio à Expedição quanto na colaboração posterior a ela, no cálculo de medidas astronômicas e classificação de objetos da fauna e flora das regiões por onde a expedição passou, cerca de $80 \%$ pertenciam a um grupo muito específico e com interesses bastante ambiciosos, liderados pelo físico e superintendente da Coast Survey, Alexander Dallas Bache - os Lazaronni Scientists ${ }^{1}$. Em outras palavras, Gilliss, um oficial-astrônomo da U. S. Navy, dialogou e apoiou as demandas desse grupo em meio às discussões sobre a aprovação da expedição astronômica ao Chile.

O grupo dos Lazaronni possuía grande interesse na promoção da ciência nos Estados Unidos e tinha como um de seus principais objetivos ganhar o apoio oficial do governo para a ciência americana ainda na primeira

\footnotetext{
${ }^{1}$ Sobre este grupo, conferir: DEPREE, A. Hunter."The Founding of the National Academy of Sciences-A Reinterpretation."Proceedings of the American Philosophical Society. Vol. 101, No. 5 (Oct. 31, 1957), pp. 434-440. Cf também: MILLER, Lillian B. The Lazzaroni: Science and Scientists in Mid-Nineteenth-Century America. Washington, D.C.: Smithsonian Institution Press, 1972.
} 
metade do século XIX. No entanto, esse grupo acreditava que havia uma distinção entre os cientistas práticos — aqueles que atuavam fora dos muros das universidades e instituições renomadas - e os acadêmicos os quais ambicionavam por um fazer científico normatizado e institucionalizado, baseado na comprovação e na confirmação dos pares, formados somente por profissionais da ciência ligados a academias e instituições científicas importantes. ${ }^{2}$ Esse seleto grupo deveria desenvolver pesquisas dentro dos padrões europeus e possuíam uma afinidade especial com pesquisadores germânicos, pois admiravam a forma como institucionalizaram o saber nas universidades.

"Lazzaroni Scientific" foi um nome criado por Alexander Dallas Bache. O termo "Lazzaroni" era o nome dado aos desocupados sem-teto de Nápoles que viviam de trabalhos temporários ou da mendicância e eram recebidos pelo Hospital de São Lázaro. Talvez a escolha do nome tenha se dado justamente por esse grupo de cientistas sentir que não havia um "teto" para abrigar a ciência tal qual eles acreditavam que deveria ser feita e, para além disso, por quem deveria ser mantida - o Governo Federal. Ademais, este grupo se manteve "isolado" em relação à forma como acreditavam que se deveria fazer ciência, já que suas ideias não eram bem recebidas no ambiente científico norte-americano de fins da primeira metade do século XIX, que garantia o espaço dos "cientistas práticos", que não eram propriamente profissionais da ciência. Por fim, estes cientistas foram os fundadores da National Academic of Sciences - a NAS - em 1863, após longos anos de empenho com essa finalidade.

\footnotetext{
${ }^{2}$ Para um exemplo de um cientista amador que ajudou a influenciar expedições da Marinha, ver o caso de John Cleves Symmes que defendia que a Terra era oca em seu centro, com possíveis intercomunicações entre o Polo norte e o Polo sul, já que os animas de uma e outra região eram semelhantes. A U. S. Exploring Expedition, de Charles Wilkes, entre 1838 e 1842, procurou verificar tal máxima. Entretanto, o que se verificou foi que a Antártida era um sétimo continente, além dos demais. Cf.: JUNQUEIRA, Mary Anne. Um outro continente: a disputa pela Antártida. In: Op. Cit., 2015.
} 
Estes Lazzaroni eram em sua maioria cientistas profissionais, professores universitários, interessados em problemas geofísicos, que admitiram cientistas de outras áreas dentro do grupo. Assim, seus interesses e áreas de influência se estenderam a todas as ciências e incluíram grande parte das pesquisas realizadas nas universidades e vinculadas às instituições do governo. Atuantes em universidades como Harvard, ou instituições como o Smithsonian Institution, eles desejavam promover o desenvolvimento de uma comunidade científica formada apenas por "profissionais" da ciência nos Estados Unidos, como já dito, e espelhando-se nas estruturas acadêmicas autocráticas de universidades europeias. Os membros do Lazzaroni desejavam, portanto, a distinção destes profissionais e um espaço de destaque para os mesmos junto ao Governo Federal.

Criteriosos, seus membros deveriam atender a um determinado modelo de excelência acadêmica, e usaram de sua influência contra qualquer indivíduo que não correspondesse às expectativas por eles geradas sobre o que consideravam "produções científicas de qualidade". Os integrantes do grupo dos Lazzaroni eram: Alexander Dallas Bache, físico e matemático, além de superintendente da Coast Survey; o também matemático Benjamin Peirce; Louis Agassiz, zoólogo e geólogo; o físico Joseph Henry; o químico Oliver Wolcott Gibbs; o astrônomo Benjamin Apthorp Gould; o químico e físico John Fries Frazer; o geologista James Dwight Dana; e o professor de Literatura grega em Harvard e, depois, reitor dessa universidade Cornelius Conway Felton (1807-1862). A maior parte deles estava instalada dentro dos muros das universidades e instituições científicas renomadas. Os chamados "amigos" dos Lazzaroni eram, em geral, cientistas, alguns do exército e da U. S. Navy, além de políticos com atuações fora do universo acadêmico, mas simpatizantes das propostas do grupo: James Melville Gilliss, James Hall, paleontólogo, os senadores Henry Wilson (1812-1875) e Jefferson Finis Davis (1808-1889), amigos muito próximos de Bache desde West Point. 
Alguns cientistas importantes ficaram fora do grupo. Muitos por divergências quanto a seu formato, outros por desentendimentos pessoais com seus líderes, como no caso de Maury. Bache, então superintendente da Coast Survey não aprovou quando este passou a trabalhar em uma área próxima de uma de suas especialidades, a Geodesia. No entanto, Maury foi incumbido por outra instituição do governo, a U.S. Navy, para criar cartas a fim de diminuir os naufrágios. Essa aproximação de sua área, somada ao fato de Maury ter ocupado o lugar que deveria ser de Gilliss como superintendente do Observatório Naval, o tornou uma persona non grata nesse grupo influente de cientistas. Diante deste fato, podemos inferir que para os Lazaronni, ter Gilliss no comando de uma unidade voltada a estudos científicos na Marinha possibilitaria a ampliação de sua área de influência, fato que se confirma quando se constata o forte vínculo de Gilliss com o grupo. Ademais, muitos de seus representantes estavam à frente de pesquisas governamentais, ou eram capitães da Marinha ou professores de universidades norte-americanas, como vimos.

Havia dois senadores compondo o grupo e estes tiveram papel fundamental para a aprovação e nascimento da NAS. Articulados, os Lazzaroni travaram embates, costuraram alianças e conquistaram alguns dos seus objetivos. Como mencionado, veio deles o necessário apoio científico diante do Congresso para aprovação, planejamento e posteriores cálculos astronômicos recolhidos durante a expedição astronômica ao Chile.

Ao pesquisar a existência desse grupo e suas posteriores conquistas, notamos que muitos cientistas norte-americanos buscaram contato e estreitaram laços com os germânicos, buscando inclusive se pautar em seu modelo científico. Isso explica também o contato de Gilliss com o matemático e astrônomo Christian Gerling, um astrônomo germânico, vinculado à universidade de Marburg, cuja influência e troca de conhecimentos e 
pesquisas astronômicas foram determinantes para motivar Gilliss a tornar realidade a expedição astronômica.

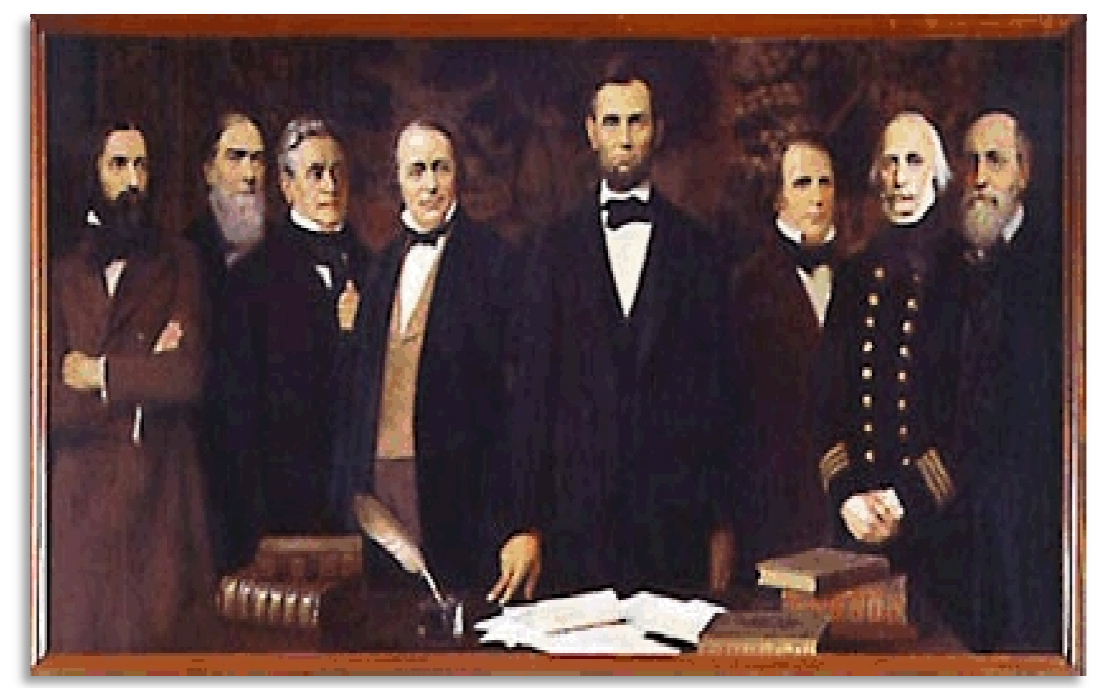

Imagem dos Lazzaroni Scientist junto ao presidente A. Lincoln ${ }^{3}$ Da esquerda para a direita: Benjamin Peirce, Alexander Dallas Bache (primeiro presidente da Academia), Joseph Henry, Louis Agassiz, o presidente Abraham Lincoln, o senador Wilson, o almirante Charles Henry Davis, e Benjamin Apthorp Gould.

Citar esse grupo é importante porque nos ajuda a compreender como, apesar da ideia da expedição ter partido do próprio Gilliss, e não do Secretário da Marinha, este projeto conseguiu ir adiante e tornar-se realidade. É provável que o apoio de oficiais da U. S. Navy ao grupo de acadêmicos tenha se devido ao fato de que os resultados das expedições da arma, como muitas experimentações científicas, eram incertos e sem utilidade imediata.

$\mathrm{O}$ apoio científico de peso e a existência de dois senadores ligados ao grupo de cientistas a qual Gilliss pertencia me parece ter sido fundamental para que a expedição fosse aprovada. Por outro lado, o pouco comprometimento de Maury com a expedição, como também veremos adiante, parece se justificar quando descobrimos as disputas e inimizades existentes dentro do campo de cientistas dos Estados Unidos. Indo além, a descoberta de um grupo tão comprometido com a profissionalização do fazer

\footnotetext{
${ }^{3}$ Imagem disponível em: http://www.nasonline.org/about-nas/history/archives/nas-incorporators.html. Acesso em 25/05/2015. Sobre a imagem, o site da NASA oferece a seguinte interpretação: informa que o autor da pintura, feita em 1924, foi Albert Herter, para que a mesma fosse colocada no prédio que abriga a Academia, mesmo local em que tal assinatura foi realizada.
} 
científico na primeira metade do século XIX — período em que já se reuniam e objetivavam criar uma academia nacional de ciências — indica a iniciativa em fins da primeira metade do século XIX em desenvolver saberes "científicos modernos".

\title{
2.2 - A ideia da expedição e o Trânsito de Vênus
}

\begin{abstract}
"Todo o país com uma reputação de zelo científico a ganhar ou a manter quis cooperar na grande empresa cosmopolita do trânsito (de Vênus)”
\end{abstract}

Agnes Mary Clerke ${ }^{4}$

No século XIX, como se sabe, houve um notável desenvolvimento científico. Inúmeras instituições e associações científicas foram fundadas ou ampliadas e seus membros, antes reconhecidos apenas como eruditos ou sábios, encontraram nas Universidades e instituições do governo um posto oficial, como acabamos de analisar. Assim, se tornavam pesquisadores com uma carreira científica. No campo da Astronomia, na primeira metade daquele século, o foco dos estudos manteve-se nas observações de estrelas e planetas. O desafio era compreender o céu, a fim de se obter benefícios na terra. Especialmente a parte da Astronomia voltada para medições estelares no intuito de se estabelecer localização em paragens distantes exigia precisão, cujo progresso dependia de cálculos cuidadosos. Esse processo foi incrementando com a invenção de novos e aprimoramento de antigos instrumentos, que tornou viável realizar expedições que buscavam obter

${ }^{4}$ CLERK, Agnes Mary. A popular history of Astronomy during the nineteenth century. Cambridge University Press, 1885.p. 278. 
medidas precisas para localização em alto- mar, como já dito. Soma-se a isso, o esforço no campo para se instituir estudos sobre Meteorologia.

Como afirma Rebekah Higgitt, a Astronomia é mais colaborativa e menos cooperativa do que os relatos de expedições sugerem. Sendo uma ciência que requer um esforço internacional, a colaboração entre astrônomos se impunha como necessária e não como opcional. No entanto, as rivalidades nacionais e os interesses pelo acesso a rotas de comércio, matérias-primas, mercados e conhecimento de regiões ainda pouco mapeadas por cientistas ocidentais foram altamente relevantes para a escolha dos locais onde astrônomos realizariam suas observações. ${ }^{5}$

A ideia da expedição astronômica de Gilliss nasceu, como vimos, a partir de uma série de cartas trocadas entre ele e Christian Ludwig Gerling, um importante físico, matemático e astrônomo, da Universidade de Marburg, hoje parte da Alemanha. Em carta que foi endereçada ao oficial norteamericano, em 1847, Gerling propôs um método inovador que tinha a ambição de obter mensurações precisas da paralaxe solar - medida astronômica capaz de fornecer dados exatos sobre a longitude. Caso seu método funcionasse, eles alcançariam êxito em um empreendimento cujos astrônomos julgavam ser possível atingir somente em duas décadas, a partir das observações do Trânsito de Vênus, quando este planeta se alinha com a Terra e medições astronômicas importantes eram e são aferidas.

No volume III de seu relatório de viagem, Gilliss iniciou informando ao leitor sobre os objetivos da expedição. Para tanto, compilou vários trechos de cartas trocadas com Gerling. Escolho justamente aquela em que o alemão apresentou o seu método para compreendermos as pretensões científicas do astrônomo, bem como a forma como construiu seus argumentos para

\footnotetext{
5 Cf: HIGGITT, Rebekah. "What they didn't tell you about the transit of Venus". Disponível em: http://www.theguardian.com/science/blog/2012/jun/12/transit-venus. Acesso em 20/07/2013.
} 
persuadir Gilliss a "comprar" sua ideia e experimentar nas Américas seu método inovador:

O assunto é este: Eu sou da opinião de que os astrônomos agiram imprudentemente ao considerar a paralaxe solar deduzida a partir do trânsito de Vênus em 1761 e 1769, suficientemente correta, e não se valeram de métodos mais modernos de observação com a finalidade de adquirir gradualmente o conhecimento mais preciso sobre o assunto. [...] Há, de qualquer forma, um terceiro método, que foi apresentado a mim há algum tempo atrás, e eu não posso compreender porque foi totalmente negligenciado. Eu quero dizer, pelas observações de Vênus durante o período de sua movimentação retrógrada e mais especificamente quando o planeta está estacionário. (quando passa vários dias em uma mesma posição).

[...] Eu tenho toda razão para acreditar que resultados mais contundentes serão obtidos com instrumentos meridianos nos observatórios em hemisférios opostos, mas assentados quase sob o mesmo meridiano. [...] Em minha opinião, então, deveria ser nossa finalidade multiplicar observações meridionais de Vênus quando ele está estacionário, e nos esforçar em obter medidas micrométricas de todas as partes da Terra, mais especificamente a partir dos viajantes. [...] A sinopse anterior de meu relato irá, eu espero, chegar até você impresso, em um curto espaço de tempo. Enquanto isso, eu peço para que examine o assunto, e se concordar comigo, acredito que você fará com que surja interesse entre os astrônomos americanos tanto quanto puder, pois para minha lisonja, minhas observações serão instituídas este ano nos observatórios europeus. ${ }^{6}$

\footnotetext{
${ }^{6}$ GILLISS, op.cit., vl III, pp. III-IV. No original: The subject is this: I am of opinion that astronomers act unwisely in considering the solar parallax deduced from the transits of Venus in 1761 and 1769 sufficiently correct, and do not avail themselves of more modern methods of observation for the purpose of gradually acquiring more accurate knowledge of it.[...] There is, however, a third method, which presented itself to me some time ago, and I cannot comprehend why it should have been so entire neglected - I mean by observations of Venus during the period of its retrograde motion, and more especially when the planet is stationary. [...] I have every reason to believe that most excellent results are obtainable with meridian instruments at observatories in opposite hemispheres, but lying nearly under the same meridian. [...] In my opinion, then, it should be our object to multiply meridian observations of Venus about the periods when it is stationary, and endeavor to obtain micrometrical measurements from all parts of the earth, more especially from voyagers. [...]No doubt this will soon be done, should astronomers be inclined to adopt my proposition; but I send you what I have found for 1847, The preceding synopsis of my paper will, I hope, reach you in print after a while. Meantime, I beg you will examine the subject, and should you coincide in my views I trust you will interest American astronomers as far as you can, for I flatter myself that observations will be instituted this year at European observatories.
} 
Gerling, como vimos, pensando nos problemas e limitações encontrados pelos astrônomos que observaram os Trânsitos de Vênus em 1761 e 1769 acreditava que os problemas de medição da paralaxe solar deveriam ser resolvidos antes do Trânsito de Vênus que ocorreria em 1874. Assim, ele parece ter buscado alternativas para uma solução imediata. Com a sua proposta de comparar medições nos Hemisfério Norte e Sul, Gerling acreditava resolver o problema. No entanto, pela própria natureza colaborativa da Astronomia, seu projeto necessitava de um esforço conjunto, envolvendo astrônomos das Américas que realizassem observações simultâneas em pontos distintos do continente. Gerling tentou persuadir Gilliss a abraçar sua ideia, e conseguiu.

Gilliss publicou a carta acima e enviou a mesma para os líderes de instituições interessadas no tema, principalmente entre os Lazzaroni que também eram associados das duas instituições procuradas por ele nesse primeiro momento: a American Philosophical Society e a Academy of Arts and Sciences. Para esses líderes, Gilliss pediu primeiramente um parecer sobre o método proposto por Gerling e a ideia da Expedição e, após, uma carta de recomendação para o Congresso, que ambos forneceram após analisarem a proposta. Ele também encaminhou a carta de Gerling para os observatórios astronômicos dos Estados Unidos. Em seguida, após as considerações dos cientistas a quem buscou o parecer, e com o apoio desses, Gilliss propôs a expedição astronômica ao Chile para a U. S. Navy.

As cartas trocadas entre esses cientistas são bastante informativas quanto ao lugar da ciência no período e também com relação aos interesses em jogo naquele momento, tanto no campo da ciência quanto no da política. Vejamos então como Gilliss respondeu a Gerling já com a intenção de inserirse de forma mais assertiva nos programas europeus. Para isso, reforçou a importância da "América" para o bom andamento do empreendimento astronômico: 
América [Hemisfério Ocidental] oferece maiores vantagens para os observatórios localizados no mesmo meridiano, ou próximos a ele, do que qualquer outro país [europeu] em razão da sua enorme extensão de norte a sul. Consideramos primordialmente uma estação [de observação] no continente, pela razão já mencionada, que pode ser uma contribuição do Novo para o Velho Mundo. [...] É evidentemente importante que as estações de observações que estão para serem feitas devem estar separadas o mais distante possível. Agora, os observatórios do Norte [Estados Unidos] já estão estabelecidos, por conseguinte, torna-se desejável que a estação do sul [América do Sul] seja feita o mais próximo da extremidade do continente como as circunstâncias justificarão. Essas circunstâncias são: clima, acessibilidade e meios de sustento dos observadores durante a sua estada no país. ${ }^{7}$

Nota-se a insistência para que fosse instalado um observatório na América do Sul com apoio dos Estados Unidos. Assim, os oficiais poderiam realizar suas observações a partir de Washington, em um esforço de colaboração com os cientistas na América do Sul, para tornar viável a obtenção das medidas das paralaxes. Gilliss, como já dito, compilou em seu relatório várias correspondências trocadas com Gerling e também entre os cientistas norte-americanos. Nessas fontes podemos observar alguns temas predominantes: informações sobre a aquisição de aparelhos para observações astronômicas, trocas de pareceres e aconselhamentos sobre o melhor local para uma expedição ao Sul, a constante afirmação dos missivistas sobre seus avanços e a importância na busca pela real medida da paralaxe solar. Nota-se, assim, uma complexa trama de interesses nacionais e transnacionais caminhando lado a lado.

\footnotetext{
${ }^{7}$ GILLISS.op.cit., Vl. III, p.V. No original: America offers greater advantages to observatories lying on the same or nearly the same meridian than any other country - its greatest length being north and south. Deeming a station on this continent of paramount consequence, for the reason already mentioned, that it may be a contribution from the New to the Old World, [...] it is evidently important that the stations from which observations are to be made should be separated as widely as possible. Now, the northern observatories are already established, therefore it becomes desirable that the southern station be made as near to the extremity of the continent as circumstances will justify; and these circumstances are, climate, accessibility, and means of sustenance for the observers during their residence.
} 
Gilliss, como já dito, trocou correspondência com matemáticos e astrônomos locais para verificar a viabilidade de se executar o método de Gerling. Assim, ao mesmo tempo em que avaliava as possibilidades de sucesso de uma expedição astronômica para conseguir as medidas da paralaxe solar, envolvia nomes de cientistas importantes em sua empreitada: novamente os Lazaronni, que, através de suas reputações como cientistas, somado ao nome das instituições a que pertenciam, foram consultados. Eles o ajudaram na viabilidade do plano e também a dar credibilidade ao projeto diante da Marinha e do Congresso dos Estados Unidos. Vejamos um excerto de uma das cartas, emitindo o parecer inicial favorável sobre a expedição, o texto é do físico, matemático e então superintendente da Coast Survey, Alexander Bache:

Como não havia dúvida, o exame mais profundo da nossa proposta exauriu as várias vertentes do problema. A importância do questionamento é amplamente admitida. Mas há diferentes correntes de opinião nas discussões sobre a questão da probabilidade de se obter novos dados para a paralaxe solar na diminuição do provável erro do valor obtido a partir do trânsito de Vênus. Não vejo, no entanto, que as duas razões que fortemente favorecem o método do Dr. Gerling encontrem quaisquer argumentos opostos. $\mathrm{O}$ grande número de observações sobre os quais os resultados podem ser fundados, e a independência do novo método com relação ao utilizado anteriormente, são, de fato, características marcantes neste método.

[...] Como é bem salientado na correspondência, se a Expedição mostrasse que nenhuma nova força poderia ser creditada ao valor da paralaxe solar através desse método, os resultados indiretos de outras observações seriam mais valiosos; nenhuma expedição semelhante jamais foi estéril de resultados científicos. Nesta perspectiva, observações meteorológicas e magnéticas poderiam ser combinadas com as observações astronômicas. [...] Eu não tenho nenhuma dúvida de que você pode apresentar um plano bem consistente em detalhes e bem moderado nos custos exigidos ao 
honorável Secretário da Marinha, e ele atribuirá consideração favorável $[\ldots]^{8}$

\section{Gilliss procurou embasar a expedição com o parecer favorável de} especialistas. Ele compilou outro parecer, realizado pelo professor Benjamin Peirce, matemático e membro dos Lazzaroni scientists:

Uma medida mais precisa da paralaxe do sol pelo método proposto por você e Dr. Gerling não pode ser considerado como inferior em importância em relação a qualquer problema na astronomia prática, e quando sustentado quanto à sua exequibilidade pelas opiniões do Dr. Bache e Mr. Walker, cuja autoridade sobre o uso de instrumentos astronômicos não podem ser subestimadas por nenhum testemunho vivo, não pode haver mais nenhuma dúvida quanto à sua conveniência. Mais cordialmente, então como deliberado, eu the envio meu humilde testemunho em favor do empreendimento o qual você tem tanto apreço, e é tão certo de cumprir, se está, como parece estar, dentro dos limites de razoável possibilidade. Deixe-me suplicar-lhe, entretanto, em não se satisfazer com nada inferior aos melhores instrumentos possíveis que a arte pode fornecer, porque tais instrumentos parecem-me absolutamente indispensáveis, enquanto as observações admiráveis que você tem publicado são uma garantia suficiente para a habilidade com que vai realizar o seu manuseio. Devo antes, trazer o assunto para a Academia no início do mês de Janeiro, e ficaria muito decepcionado se uma resolução não for imediatamente adotada na aprovação de seu projeto. ${ }^{9}$

\footnotetext{
${ }^{8}$ GILLISS, op.cit.Vl III, pp.X-XI. No original: "As was no doubt expected, the searching examination to which your proposal has given rise has nearly exhausted the various bearings of the problem. The importance of the inquiry is very generally admitted. In discussing the question of the probability of obtaining new data for the solar parallax which shall diminish the probable error of the value obtained from the transit of Venus, there are different shades of opinion expressed. I do not see, however, that the two reasons which strongly favor Dr. Gerling's method are met by any opposing arguments. The large number of observations upon which results may be founded, and the independence of the new method with that formerly used, are, indeed, striking features in this method. [...] As is well pointed out in the correspondence, if the Expedition should result in showing that no new strength could be given by this method to the value of the solar parallax, the indirect results from other observations would be most valuable; no similar expedition has ever been barren of scientific results. In this view of the subject, meteorological and magnetical observations should be combined with the astronomical observations. [...]I have no doubt that you can present a plan to the honorable the Secretary of the Navy so well matured in its details, and so moderate in the expenditures required, that he will give it that favorable consideration [...].

${ }^{9}$ GILLISS, op.cit, Vol. III, p. XI. No original: "A more accurate measurement of the sun's parallax in the method proposed by yourself and Dr. Gerling cannot be regarded as inferior in importance to any problem in practical astronomy; and when sustained as to its practicability by the opinions of Dr. Bache and Mr. Walker, whose authority upon the use of astronomical instruments can be weighed down by no living
} 
Os excertos acima comprovam a ligação do oficial Gilliss com iminentes cientistas do período e particularmente com os Lazzaroni. Notamos também o cuidado que os mesmos têm ao endossar a expedição, já que ambos admitem a possibilidade da mesma não conseguir obter os cálculos pretendidos. Ainda assim, consideraram a expedição importante, pois oferecia a chance de testar um novo método - o de Gerling - e, para além dos cálculos da paralaxe, poderiam obter novos dados magnéticos e meteorológicos. Portanto, a expedição para eles era válida.

Após análises cuidadosas, tanto a American Philosophical Society como a American Academy of Arts and Sciences enviaram cartas de recomendação a serem anexadas ao projeto da expedição. Da primeira instituição, assinam o matemático Robert. M. Patterson, o químico Richard S. McCulloh e o matemático E. Ottis Kendall. A carta da segunda instituição foi enviada a Gilliss por Asa Gray, então secretário da Academia e membro dos Lazzaroni Scientists. ${ }^{10}$

Essas cartas denotam o entusiasmo e aval da comunidade científica diante do projeto inovador, a ponto de proporem a colaboração entre várias instituições para tornar a execução da expedição um sucesso, como veremos adiante. Além do peso do aval das instituições, notamos que elas ressaltam os benefícios que a expedição e suas descobertas trariam para o país. Ou seja, estava em jogo um projeto de interesses variados, nos quais as ciência, como já dito, era um meio para se obter esses objetivos.

testimony, there can be no further question as to its expediency. Most cordially, therefore, as well as deliberately, I send you my humble testimony in favor of the enterprise you have so much at heart and are so certain to accomplish, if it is, as it appears to be, within the bounds of reasonable possibility. Let me entreat you, however, not to be satisfied with anything inferior to the best possible instruments which art can furnish, for such instruments seem to me absolutely indispensable, while the admirable observations which you have published are a sufficient guaranty for the skill with which you will conduct their manipulation. "I shall bring the subject before the Academy early in the month of January, and shall be greatly disappointed if a resolution is not immediately adopted in approbation of your project."

${ }^{10}$ Cf. GILLISS,op.cit., Vol. III., p.IXV-XV. 


\subsection{1 - Os objetivos astronômicos e o planejamento da viagem}

Como já explicado, a expedição tinha como principal objetivo obter as medidas da paralaxe solar, fato nunca antes conseguido em ocasiões fora da passagem do Trânsito de Vênus.

Paralaxe é uma medida que se obtém a partir da diferença na posição aparente de um objeto que foi visto por observadores em locais distintos. A paralaxe estelar é utilizada para medir a distância das estrelas, utilizando como referencial o movimento da Terra em sua órbita. Só é possível obter essa medida, comparando-se as medidas de dois observadores localizados em pontos distintos do Globo.

No século XVII, o cientista Edmond Halley afirmou ser possível calcular a distância da Terra ao Sol através da observação do Trânsito de Vênus. Halley afirmava que, se a passagem de Vênus entre a Terra e o Sol fosse observada de vários locais do Globo em longitudes diferentes (ou seja, a partir do método da paralaxe), seria possível calcular a distância da própria Terra em relação ao astro. Assim, reitero que a técnica envolvia precisas observações da pequena diferença do momento de início ou de término do trânsito, em pontos bastante separados na superfície da Terra, ajudando a calcular uma mais precisa localização em alto-mar.

Um trânsito de Vênus pode ser visto da Terra. Esse raro fenômeno ocorre quando o Sol, Vênus e a Terra se encontram alinhados, como já indicado, e é semelhante ao eclipse solar. Os Trânsitos de Vênus são acontecimentos raros. Até hoje existem sete trânsitos registrados: 1639, 1761 e 1769, 1874 e 1882, e 2004 e 2012. Note-se que o Trânsito ocorre "aos pares" em anos próximos como 1874-1882 e 2004-2012. Dada a sua raridade, e sua importância para determinar a distância do Sol a Terra, foram muitas as expedições que levaram grupos de astrônomos e interessados até paragens distantes. 
No século XIX, os EUA enviaram oito expedições para observar o Trânsito de Vênus (1874) e quinze expedições se deslocaram para lugares distintos do Globo para observar o segundo (1882). O número de países e de cientistas envolvidos na observação do trânsito de 1882 também foi bastante relevante. Das quinze expedições levadas a cabo pelos Estados Unidos, dez foram dentro das suas fronteiras e as demais em locais selecionados na América Central e do Sul, Nova Zelândia e África do Sul. Os franceses organizaram cerca de dezessete expedições: treze fora da Europa, nomeadamente nos EUA, nas Américas Central e Sul. Os ingleses organizaram mais de trinta expedições, distribuídas pela Nova Zelândia, Antilhas, Austrália, EUA, África do Sul, Canadá e diversas ilhas no Oceano Índico, além da América do Sul. A maior potência marítima do planeta, à época, investiu nessas medições que garantiriam exata localização em alto mar e segurança de seus navios comerciais e militares. Alemanha, Argentina, Bélgica, Brasil, Dinamarca, Irlanda e Itália também organizaram expedições para observar o Trânsito de Vênus.

O Brasil organizou três expedições, levadas a cabo pelo Observatório Nacional. A primeira foi feita em Olinda e coordenada por J. d'O. Lacaille, a segunda foi comandada pelo Barão de Teffé na ilha de São Tomaz (Antilhas); e a terceira, teve à frente Luis Cruls, diretor do Observatório Nacional e coordenador das missões em Punta Arenas, no Chile. ${ }^{11}$

A última oportunidade para a atual geração observar o Trânsito de Vênus ocorreu em junho de 2012. O próximo par de trânsitos ocorrerá apenas em 2117 e 2125. Ainda hoje, o Trânsito de Vênus mobiliza cientistas e interessados em geral e é considerado um grande evento do campo da Astronomia. Voltemos à expedição de Gilliss ao Chile.

Após trocar ideias sobre a viagem com os principais membros das instituições científicas de seu país e com Gerling, como vimos, Gilliss então

${ }^{11}$ Cf: http://www.observatorio.ufmg.br/pas57.htm . Acesso em 21/12/2012. 
concebeu o projeto e submeteu a proposta da expedição à Secretaria da U.S. Navy, que por sua vez a encaminhou ao Congresso. Os defensores da expedição astronômica afirmavam, como vimos na reprodução de trechos da carta acima, que o aprimoramento dos cálculos da paralaxe solar seria útil na navegação e traria "honra" ao país ${ }^{12}$. Um dos principais argumentos utilizados pelos defensores da proposta era de que, ao apoiar uma expedição astronômica, o país demonstraria seu apreço e seu estímulo ao desenvolvimento da ciência e poderia cultivar contatos com os europeus, adentrando ao espaço internacional do debate científico sobre o tema.

No entanto, é interessante observar que, apesar das discussões sobre a expedição nos meios científicos permanecerem focadas na questão da Astronomia e da viabilidade do método de Gerling e da adoção das medições em dois lugares distintos do Globo, a carta enviada ao governo continha argumentos que buscavam ligar o avanço da Astronomia a possíveis benefícios para o governo e para o comércio norte-americanos. A proposta, enviada ao Congresso, pelo Comitê de assuntos navais, iniciava-se da seguinte forma:

Estas observações se forem feitas com sucesso na forma proposta, vão apresentar dados unicamente americanos para uma nova e independente determinação do mais importante elemento, um elemento que entra em todas as nossas determinações das longitudes, afetando a precisão e segurança de todos esses cálculos e, portanto, da maior utilidade possível não só para o governo, mas para todos os cidadãos empreendedores do nosso país. A partir desse ponto de vista da expedição recomenda-se um caloroso encorajamento e ajuda eficaz na sua promoção. ${ }^{13}$

\footnotetext{
${ }^{12} \mathrm{Cf}$. as cartas de recomendações publicadas por Gilliss, no volume III de seu relatório.

${ }^{13}$ GILLISS, op. Cit.,Vl. III, p.V. No original: These observations, if successfully made in the manner proposed, will present data solely American for a new and independent determination of this most important element an element which enters into all our determinations of longitude, affecting the accuracy and safety of all such calculations, and therefore possessed of the highest possible utility, not only to the government, but to all the enterprising citizens of our country. In this view the expedition commends itself to us for warm encouragement and efficient aid in its promotion.
} 
Ainda que o método de observação fosse proposto por um alemão, os realizadores seriam norte-americanos. Mais: seria responsável pelas medições nos Estados e no Chile, ainda que os chilenos estivessem na operação e isto, era um fator que pesava nas decisões, já que, como podemos observar, era de interesse dos Estados Unidos poder entrar no debate internacional sobre o tema.

Quanto à escolha do país adequado para instalar o Observatório e realizar as observações, Gilliss, além de pedir conselhos a Gerling, realizou uma extensa pesquisa sobre o Chile. O autor baseou-se em vários viajantes, entre eles, as observações feitas por Charles Darwin, durante a expedição que realizou a bordo do Beagle (1831-1836), e comenta despender duas semanas na Biblioteca do Congresso, realizando pesquisas sobre o país sulamericano. $^{14}$

O Congresso, então, convencido da importância da expedição, deu sua aprovação, reservando para a mesma cinco mil dólares. Posteriormente, adicionou mais seis mil e quatrocentos dólares para a compra de instrumentos astronômicos. Nos dias atuais, este valor seria em torno de duzentos e sessenta mil dólares. ${ }^{15}$

Nota-se que Gilliss, ao identificar que muitos dos instrumentos existentes estavam avariados, descobriu que seria necessário mais dinheiro. $\mathrm{Na}$ tentativa de conseguir mais verba sem ter que passar pela burocracia do governo, buscou ajuda financeira junto a membros do Smithsonian Institution, que se comprometeram em arrecadar os fundos necessários. No entanto, o Congresso, considerando ser a expedição um empreendimento governamental, não aprovou a doação por parte de civis, ainda que ligados à Instituição. Assim, decidiu adicionar o valor citado acima para a realização de compras dos instrumentos necessários e a boa realização da expedição. ${ }^{16}$

\footnotetext{
${ }^{14}$ GILLISS,op.cit., V1.III,p.VI.

${ }^{15}$ Esse cálculo foi baseado no método apresentado na nota de rodapé 20 do primeiro capítulo.

${ }^{16}$ Cf. GILLISS, op.cit., Vl. III, p. XXIV.
} 
Assim que a expedição foi aprovada, Gilliss enviou o planejamento da viagem para apreciação das instituições científicas que apoiavam a viagem, e obteve o aval das mesmas, com pequenas modificações. Por exemplo, Gilliss pretendia levar apenas um assistente consigo, ao passo que os cientistas aconselharam que ele levasse três, o que foi acatado. Foram montados comitês para essas análises. A American Philosophical Society foi a primeira a realizar a avaliação do programa, e Gilliss cita outros nomes e instituições: Benjamin Peirce, Joseph Levering e também o oficial Charles. H. Davis, membro do Conselho Naval e nome indicado pelo presidente da Academy of Arts and Sciences. Por fim, Gilliss cita outros dois comitês que se reuniram na Philadelphia. Todas essas comissões aprovaram o planejamento da expedição e recomendaram a adoção do programa ao Secretário da Marinha. ${ }^{17}$

De acordo com o relatório, em seu planejamento minucioso, Gilliss detalhou a compra de instrumentos astronômicos, o número de assistentes, as rotas da viagem e os objetivos astronômicos da expedição, tais como obter as medidas da paralaxe solar, as medidas de declinação de Vênus e Marte, catalogar as estrelas do sul e recolher dados magnéticos e meteorológicos dos países visitados. Cada objetivo da expedição foi escrito de forma detalhada, como já informado. Até o número de horas para cada tarefa foi prédeterminado. Um exemplo é a elaboração do catálogo de estrelas, trabalho em que seriam dedicadas três horas de cada noite clara. Ficou decidido que o meridiano zero a ser utilizado seria o de Greenwich, por ser mais conhecido que o de Washington.

Também foram estipulados os equipamentos necessários e $\mathrm{o}$ cronograma de trabalho para realizar as observações magnéticas, de cometas, meteorológicas e de terremotos, este último, obviamente, sem cronograma, mas contaram com equipamentos adequados para aferir os abalos sempre que estes ocorressem.

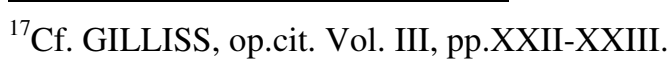


Nas horas vagas, ficou estabelecido que a equipe fizesse observações e coletas relacionadas à Botânica e à Geografia local. Além disso, outras indicações de observações e coletas foram instruídas pelo governo norteamericano, tais como elaborar relatos sobre a cultura, comércio entre outros aspectos das sociedades visitadas.

Muitos dos aparelhos necessários foram obtidos da Europa, principalmente em Munique e Berlim. Aqui, novamente indiciamos o apreço norte-americano pelos cientistas da região e seus técnicos.

Em se tratando da Astronomia, é importante salientarmos que os instrumentos são parte indissociável do sucesso da expedição. Em diferentes momentos da história, os instrumentos corresponderam a necessidades diversas. Mas desde a segunda metade do século XVIII, seu constante aperfeiçoamento e a necessidade de serem manuseados por homens preparados e treinados para utilizá-los, se deveu à necessidade da exatidão de medidas. Nesse sentido, os cientistas se apropriaram desses instrumentos como parte essencial do avanço da ciência, formando uma cadeia de cooperação internacional, que englobava estudiosos, academias científicas, instituições governamentais, além dos construtores dos equipamentos. ${ }^{18}$

\section{3 - A colaboração entre os Observatórios de distintas nacionalidades}

Como já dito, as observações astronômicas realizadas no Chile, principalmente aquelas para se obter a paralaxe solar, só alcançariam sucesso se realizadas em conjunto com os observatórios dos Estados Unidos. Por essa razão, Gilliss deixou instruções para os observatórios norte-americanos sobre os dias e as horas em que deveriam ser realizadas tais observações.

O tenente Matew Fontaine Maury, superintendente do United States Naval Observatory, ficou encarregado de enviar essas instruções não apenas

\footnotetext{
${ }^{18}$ Cf: BENNETT, Jim. O estatuto dos Instrumentos científicos, e LICOPPE, Christian. Barômetros e Termômetros em França no século XVIII: modalidades históricas da coordenação de medidas feitas á distância. In: GIL, Fernando(coord.). A ciência tal qual se faz.Lisboa: Tipografia Guerra, 1999.
} 
para outros observatórios norte-americanos, mas também para instituições similares europeias, solicitando a cooperação de todos com a intenção de compararem as medições e apurar os resultados. Era dever de Maury manter contato com esses observatórios, a fim de tentar garantir, ao menos dentro dos Estados Unidos, que as instruções deixadas por Gilliss fossem cumpridas.

\section{4 - A equipe da Expedição Astronômica ao Chile}

Para realizar o seu intento Gilliss levou para o Chile dois oficiais da Marinha e um assistente pessoal. A escolha dos dois primeiros inicialmente esbarrou na contenção de despesas da U. S. Navy e do Governo Federal. Ficou acertado que os oficiais participariam da expedição pelo mesmo salário que já recebiam em suas funções dentro da Marinha. Entretanto, uma viagem dessa envergadura, como se sabe, poderia ajudar a "alavancar" a carreira de um oficial. Assim, ainda que os recursos fossem poucos, não deve ter sido difícil para Gilliss selecionar homens interessados a serem treinados no âmbito da Astronomia.

Gilliss já supunha que os gastos com a expedição seria o principal fator impeditivo de aprovação pelo Congresso e, portanto, tratou de buscar todas as alternativas possíveis para minimizá-los, inclusive com relação à escolha do local a ser construído o Observatório na América do Sul, como afirma em seu relatório. Essa escolha contou, como não podia deixar de ser, com o acordo e aprovação dos chilenos.

Gilliss alegou que não gostaria de ter como assistentes homens que não estivessem dispostos a deixar seu país e o conforto de suas tarefas já rotineiras. Por isso, preferiu apostar nos voluntários para o serviço. Nesse processo, dois nomes surgiram: os oficiais Archibald MacRae (tenente) e Henry C. Hunter (guarda-marinha). Ambos foram então encaminhados para o United States Naval Observatory para receber instruções quanto à operação de instrumentos astronômicos. Aqui, é necessário informar que um dos oficiais 
não permaneceu durante todo o tempo da expedição, sendo substituído por outro. Em 1850, Hunter se machucou ao cair de um cavalo no Chile e retornou para os Estados Unidos. Somente seis meses depois chegou à América do Sul seu substituto, o oficial Ledyard Phelps. Este último, não colaborou com a escrita do relatório. No entanto, foi encontrado um livro que retrata sua vida na U.S. Navy e foi possível ter contato com suas impressões sobre o trabalho e alguns aspectos do Chile. Em momento oportuno, essa documentação será analisada. ${ }^{19}$

Um civil convidado por Gilliss, também participou da expedição: Edmond R. Smith, graduado pelo Georgetown College, foi nomeado como secretário, artista e contador. Smith foi enviado para a Universidade de Yale para estudar Botânica, Zoologia, Mineralogia e a língua espanhola. Este, ao final da expedição, decidiu permanecer no Chile e viajar pelo país, a fim de conhecer os índios Araucanos ou Mapuches. Dessa experiência nasceu também um relato de viagem, que foi impresso nos Estados Unidos e posteriormente publicado no Chile, com o título: The Araucanians; or, Notes of a tour among the indian tribs of Southern Chile. ${ }^{20}$

Tudo planejado, os oficiais a serviço de Gilliss, agora treinados para exercerem suas novas funções, estavam aptos para a missão. Assim, embarcaram para o Chile um mês antes de Gilliss, levando os instrumentos via Cabo Horn. Gilliss partiu para o Chile tomando outro trajeto, via Panamá, como mencionado. O objetivo exposto em seu relatório para tal decisão era o de que, ao realizar um trajeto diferente de seus assistentes, ele sairia dos Estados Unidos um mês depois dos demais e chegaria um mês antes dos mesmos, com tempo para definir o local, junto ao governo chileno e preparar

\footnotetext{
${ }^{19}$ Cf: SLAGLE, Jay. Ironclad captain: Seth Ledyard Phelps and the U.S. Navy, 1841-64. Ohio: The Kent State University Press, 1996.

${ }^{20}$ Cf: SMITH, Edmond Reuel. The Araucanians; or, Notes of a tour among the indian tribs of Southern Chile. New York: Harper \& Brother Publisher, 1855. Disponível em http://archive.org/stream/araucaniansorno01smitgoog\#page/n10/mode/2up .Acesso em 20/06/2013. O relato foi traduzido para o espanhol. Cf: SMITH, Edmond Reuel. Los Araucanos, o Notas sobre una gira efectuada entre las tribus indígenas de Chile meridional. Santiago del Chile: Imprenta Universitária, 1914.
} 
a instalação do Observatório Astronômico. Infelizmente, seus planos não funcionaram e ele permaneceu cerca de quatro semanas no Panamá, fato que nos rendeu representações interessantes sobre o país e sobre os yankees que embarcaram com ele para igualmente atravessarem a região e seguir viagem em direção à Califórnia.

\section{5 - A rota de viagem}

Note-se que o fato da U. S. Navy ter expedido instruções para que Gilliss atravessasse o Panamá, Colômbia e Equador seguindo em direção ao Peru, para então desembarcar no Chile, ao invés de navegar pelo Cabo Horn, nos remete a outro objetivo da viagem astronômica: o estratégico. Se a rota pelo Cabo Horn era difícil, aquela pelo Panamá era árdua. Gilliss atravessou a região em lombo de mulas e percorreu rios em embarcações precárias. Submeteu-se a um calor insuportável e ao clima úmido e inclemente. Sob o meu ponto de vista, tal escolha revela que a U. S. Navy gostaria de aproveitar a oportunidade de um oficial graduado na região para obter informações mais precisas sobre a travessia de norte-americanos para a Califórnia e, na volta, acompanhar o andamento da construção da estrada de ferro no Panamá, empreendimento norte-americano, que iniciou logo após a anexação da Califórnia aos Estados Unidos.

É importante ressaltar que, em 1850 - exatamente um ano após a partida de Gilliss - a Inglaterra e os Estados Unidos firmaram o conhecido tratado Clayton-Bulwer, no qual ficou estabelecido que se houvesse a construção de uma passagem interoceânica na América Central, nenhum dos dois países teriam o predomínio sobre o possível canal. ${ }^{21} \mathrm{Na}$ época, a Inglaterra, além de dominar o comércio na região, havia instalado uma

\footnotetext{
${ }^{21}$ Cf. SCHOULTZ, Lars. A criação de um país e a construção de um canal. In: Estados Unidos: poder e submissão. Uma história da política norte-americana em relação à América Latina. São Paulo: EDUSC, 1998.
} 
possessão na Costa dos Mosquitos, na Nicarágua, presença que incomodava os norte-americanos.

Aos poucos, a diplomacia dos Estados Unidos tratou de neutralizar esse acordo e, na segunda metade do século XIX, a U. S. Navy realizou diversas viagens aos países da América Central com o objetivo de escolher a região adequada para a construção da passagem oceânica. ${ }^{22}$ Novamente, essas viagens não ocorreram sem prévios acordos com os países da América Latina também interessados no assunto.

\section{6 - A expedição e a cooperação transnacional}

Ao pensarmos que a expedição carregava como principal objetivo as medições astronômicas, sendo, portanto, um empreendimento primordialmente científico, ainda que o objetivo principal - a obtenção exata da paralaxe solar - não tenha logrado êxito, sem dúvidas, como vimos, o empreendimento deu frutos importantes em outros aspectos. Vimos que os Estados Unidos se inseriram de forma iminente no campo da ciência astronômica e da "corrida da paralaxe". ${ }^{23}$ A publicação do catálogo das estrelas do Sul, que corrigiu o único documento existente, do século XVIII, escrito por Lacaille, trouxe respeito aos cientistas norte-americanos. Vale lembrar que as expedições norte-americanas durante o Trânsito de Vênus do século XIX colheram bons resultados, ainda que nenhuma delas conseguisse a tão sonhada medida exata da paralaxe solar.

Gilliss deixou mostras do esforço de colaboração entre as nações envolvidas com o problema da paralaxe, e também da resistência por parte do governo norte-americano em depender da boa vontade dos ingleses, ou de reconhecê-los, como podemos constatar no excerto abaixo:

\footnotetext{
${ }^{22}$ Cf.: JUNQUEIRA, Mary Anne. "Ciência, técnica e as expedições da marinha de guerra norte-americana, U.S. Navy, em direção à América Latina”. In: Varia História. Belo Horizonte: UFMG, vol. 23, 2007.

${ }^{23}$ Atualmente, técnicas mais modernas, tais como a telemetria por sondas espaciais e observações por radar das distâncias para planetas e asteroides do sistema solar, permitiram a obtenção de um valor preciso para a unidade astronômica (com precisão de $\pm 30 \mathrm{~m}$ ), eliminando assim a necessidade de cálculos por paralaxe.
} 
Muito interesse foi manifestado pela Expedição na Inglaterra, assim como no continente, e os serviços mais valiosos foram prestados pelo almirante Beaufort, Coronel Sabine, o Capitão (agora Almirante) W. H. Smyth, e outros, por seus conselhos, através da obtenção de materiais úteis para nós, e por se oferecer para facilitar nossos objetivos em todos os momentos onde quer que nós estivéssemos. [...] Estas ofertas foram ditadas por um princípio de generosidade nobre no indivíduo, como era honrosa para a nação aquele serviço que eles faziam, e eu poderia lamentar somente se os reconhecimentos do Ministério da Marinha para com estes sinais de boa vontade não pudessem ser comunicados a estes cavalheiros [...]. Portanto, eles iriam me agradecer em uma simples expressão de profunda gratidão, e acreditariam na minha certeza, que deveríamos a todo o momento estimar isso como um privilégio para prestar ajuda a qualquer um dos numerosos cientistas ou outros grupos ingleses tão magnanimamente enviados para o estrangeiro para o benefício da humanidade. ${ }^{24}$

Nota-se que Gilliss temia que a superintendência da Marinha norteamericana não reconhecesse os esforços prestados pela Inglaterra. Gentleman que era, Gilliss parecia não estar em sintonia — em alguns momentos em que se exigia as boas maneiras e gestos de gratidão "comuns" aos homens de sua classe - com a falta de reconhecimento por parte de seus superiores para com os ingleses. Se não tivéssemos um olhar atento a sua determinação em obter dados da paralaxe, "a partir de dados totalmente norte-americanos", como ele afirmou em cartas publicadas em seu relatório, poderíamos acreditar que Gilliss era um homem que colocava o avanço da Astronomia em primeiro lugar, a qualquer custo. Não era. Ele, assim como os demais de seu segmento

\footnotetext{
${ }^{24}$ GILLISS, op. Cit. V1.I, p.XXVI. No original: Much interest had been manifested for the Expedition in England, as well as on the continent, and most valuable services were rendered by Admiral Beaufort, Col.Sabine, Capt. (now Rear Admiral) W. IT. Smyth, and others, by their counsel, by obtaining useful materials for us, and by offers to facilitate our objects at all times wherever we might be. [...] These offers were dictated by a principle of generosity noble in the individual, as it was honorable to the nation whose service they adorned, and I could only regret that the acknowledgments of the Navy Department for these tokens of good will could not have been communicated to these gentlemen Therefore, they would appreciate me in a simple expression of profound gratitude, and believe my assurance, that we should at all times esteem it a privilege to render aid to any of the numerous scientific or other parties England so magnanimously sends abroad for the benefit of mankind.
} 
científico, buscava a cooperação internacional, pela própria necessidade imposta pela Astronomia, como vimos. Mas tal como os demais, pretendia chegar primeiro, mas elegantemente, como convinha a um gentleman, agradecendo a todos pela colaboração, mas indicando que o seu país havia se destacado na empreitada.

Viagens astronômicas eram realizadas no período, principalmente por Inglaterra, França, Espanha e Rússia. A maioria tinha como principal objetivo o mapeamento de estrelas e de eclipses solares. No entanto, deve-se ter em mente que a realização de muitas experiências no campo da Astronomia favorecia, como já dito, os cálculos de rotas e mapeamentos precisos de mares e oceanos e o desenvolvimento de estudos meteorológicos, que favoreciam as navegações de todas as finalidades, tanto as governamentais quanto as comerciais.

\section{7 - Resultados da expedição - sucessos, fracassos e boicotes}

Durante quatro anos, milhares de registros astronômicos foram realizados por Gilliss e seus assistentes no Chile, resultando em um importante passo no desenvolvimento da Astronomia norte-americana. Cerca de dezesseis mil estrelas foram mapeadas e centenas de registros climáticos e magnéticos foram feitos, além das medições em busca da paralaxe solar. No entanto, como já dito, o sucesso total dos objetivos não foi alcançado. Vejamos o que aconteceu.

Ao retornar do Chile, Gilliss pediu a ajuda e a validação das medições à Benjamin A. Gould, que realizou as reduções necessárias. Gould creditou êxito à primeira série de observações de Marte e, a partir delas, produziu um valor da paralaxe solar: 8"4950,07"- 07" a menos que o valor obtido por Encke, baseado nos trânsitos de Vênus do século XVIII. De acordo com o astrônomo Wendell Huffman, este novo valor para a paralaxe solar não foi aceito pelos astrônomos, e o próprio Benjamin Gould tempos depois, 
mostrou-se inseguro com o resultado, embora acreditasse que a medida pudesse estar muito próxima da realidade. No entanto, uma década depois, Gould admitiu que tais valores estavam em desacordo com as investigações realizadas posteriormente. ${ }^{25}$ Essa possibilidade nunca foi descartada pelos cientistas que validaram a viagem, pois tratava-se de um novo método. Ademais, acreditavam que a expedição científica carregava outras missões, as quais certamente teriam sucesso.

Enquanto Gilliss e sua equipe realizaram observações e medições em duzentas e dezessete noites, somente em vinte e oito dessas noites, os observatórios norte-americanos realizaram observações correspondentes. Dessas, somente dezoito de Marte, na primeira série de observações, e apenas duas, durante a segunda. De Vênus - principal objetivo da expedição, seguindo o programa proposto por Gerling, houve somente oito noites correspondentes de observações. ${ }^{26}$

A obtenção da paralaxe solar, no entanto, não alcançou o êxito esperado, pois não houve cooperação suficiente a partir dos observatórios do norte. Outro fator importante, que fugia ao controle, eram as condições climáticas de cada local. Sem um céu limpo, era impossível realizar as observações, fato que também prejudicou os resultados finais.

O professor e astrônomo Wendell W. Huffman, ao estudar a expedição de Gilliss, reconhece que ela "falhou" em obter as medidas da paralaxe solar devido a poucas medições correspondentes realizadas nos observatórios dos Estados Unidos no mesmo período. No entanto, Huffman não considera este o fator principal do fracasso. Para o autor, este foi o argumento escolhido pelos envolvidos no projeto, tal como o próprio Benjamin A. Gould, que usou as poucas observações realizadas para explicar tal fracasso. No entanto, para Huffman, a expedição falhou devido à impraticabilidade do método

\footnotetext{
${ }^{25}$ HUFFMAN, Wendell H. "The United States Naval Astronomical Expedition (1849-52) for the Solar Parallax.".Journal for the History of Astronomy, Vol.22, NO.69/3/AUG, 1991, pp.208-220.

${ }^{26}$ Ibidem.
} 
observacional projetado por Gerling e pelo programa arquitetado por Gilliss e pelos principais membros das instituições científicas antes da viagem, somadas às complicações adicionais, como mau tempo e coordenações preliminares inadequadas. Assim, a falta de cooperação teria servido, na visão deste autor, para distrair os críticos desses problemas mais básicos. ${ }^{27}$ Acredito que de fato houve pouca cooperação, fosse ela proposital ou não. Lembremos que Gilliss fazia parte do grupo dos Lazzaronis, enquanto que Maury era uma espécie de inimigo destes. As poucas observações de Washington em um período de quatro anos não podem ser creditadas apenas a falta de um céu limpo. Assim, concluo, diferentemente de Huffman, que a pouca cooperação pode ter sido um forte impeditivo de sucesso na obtenção da medida exata da paralaxe. Alcançar esses números daria enorme poder à Gilliss e ao grupo de cientistas envolvidos no projeto do qual Maury não fazia parte.

Mas Gilliss, como já citado, realizou mais do que as medidas da paralaxe solar, e ajudou a inserir os Estados Unidos da América no programa internacional astronômico e estabeleceu importantes trocas de ideias entre os astrônomos norte-americanos e o restante do mundo.

\section{8 - Publicação dos relatórios}

De volta para os Estados Unidos, Gilliss iniciou a escrita dos relatórios. Dos seis volumes esperados, ele conseguiu publicar, com o subsídio do governo, quatro volumes, com o título: "The U. S. naval astronomical expedition to the Southern hemisphere during years 1849, 50, 51, 52". A ordem é a que segue:

\footnotetext{
${ }^{27}$ HUFFMAN,op.cit.p.208.
} 


\begin{tabular}{|c|c|c|c|c|c|c|}
\hline Vol. & Autor & Título & Conteúdos & Publicação & $\mathbf{N}^{0}$ Pág. & Cópias \\
\hline I & James Gilliss & Chile & $\begin{array}{l}\text { Chile: geografia, } \\
\text { política, clima, } \\
\text { sociedade, } \\
\text { terremotos, } \\
\text { sociedade, religião, } \\
\text { cidades visitadas, } \\
\text { operações } \\
\text { astronômicas. } \\
\text { Panamá, Lima. }\end{array}$ & 1855 & 556 & 6.000 \\
\hline \multirow[t]{11}{*}{ II } & $\begin{array}{l}\text { Archibald } \\
\text { MacRae }\end{array}$ & $\begin{array}{l}\text { The Andes and } \\
\text { the Pampas }\end{array}$ & $\begin{array}{c}\text { Mendoza- San Luis } \\
\text { de La Punta- } \\
\text { Rosario: descrição } \\
\text { detalhada sobre } \\
\text { geografia, sociedade, } \\
\text { religião, governo, } \\
\text { agricultura, crimes, } \\
\text { longitude, latitude e } \\
\text { observações } \\
\text { magnéticas. }\end{array}$ & 1855 & 300 & 5000 \\
\hline & $\begin{array}{l}\text { J. Lawrence } \\
\text { Smith }\end{array}$ & Minerals & & & & \\
\hline & $\begin{array}{l}\text { Thomas } \\
\text { Ewbank }\end{array}$ & Indians Remains & & & & \\
\hline & $\begin{array}{l}\text { Spencer F. } \\
\text { Baird }\end{array}$ & Mamals & & & & \\
\hline & John Cassim & Birds & & & & \\
\hline & Charles Girard & $\begin{array}{l}\text { Reptiles, fishes, } \\
\text { and crustacean }\end{array}$ & & & & \\
\hline & A.A. Gould & Shells & & & & \\
\hline & Asa Gray & Dried plants & & & & \\
\hline & $\begin{array}{c}\text { William D. } \\
\text { Brackenbridge }\end{array}$ & $\begin{array}{l}\text { Living plants } \\
\text { and seeds }\end{array}$ & & & & \\
\hline & Jefries Wyman & Fossil Mammals & & & & \\
\hline & T. A. Conrad & Fossil Shells & & & & \\
\hline III & James Gillis & $\begin{array}{l}\text { Observations to } \\
\text { determine the } \\
\text { Solar Parallax }\end{array}$ & $\begin{array}{l}\text { Origens e operações } \\
\text { da Expedição; } \\
\text { Observações } \\
\text { astronômicas de } \\
\text { Santiago, } \\
\text { Washington, } \\
\text { Cambridge e Cabo } \\
\text { da Boa esperança. }\end{array}$ & 1856 & 492 & 6000 \\
\hline VI & James Gilliss & $\begin{array}{l}\text { Magnetical and } \\
\text { Meteorological } \\
\text { Observations }\end{array}$ & $\begin{array}{c}\text { Observações } \\
\text { magnéticas e } \\
\text { meteorológicas. }\end{array}$ & 1856 & 420 & 5000 \\
\hline
\end{tabular}

O primeiro volume do relatório foi impresso em maio de 1855. O nível elevado da impressão feita em capa dura (provavelmente de couro), cujo 
centro da capa, embora de difícil percepção, carrega um desenho em relevo do local onde foi erguido o Observatório Astronômico.

Nesse volume, o autor tratou de diferentes aspectos do Chile, dividindo-os em duas partes distintas: na primeira, descreveu o país, contemplando sua geografia, clima, terremotos, governo, condição social, fontes de agricultura e de minerais, comércio, entre tantos outros. Na segunda, Gilliss narrou a viagem até o Chile, e descreveu os locais por onde passou, como Panamá, Peru e suas primeiras experiências no país sul-americano. O volume foi finalizado com o relatório dos primeiros trabalhos astronômicos realizados e contemplou também em seus apêndices, os terremotos e observações meteorológicas.

O segundo volume, impresso em julho de 1855, conta a interessante narrativa de Archibald MacRae sobre a Argentina além das medições que realizou durante todo o trajeto. Neste volume também estão a escrita de cientistas de diversas áreas, os quais ocuparam-se em descrever e estudar as coleções minerais, animais e fósseis trazidas da expedição. Foram impressas cinco mil cópias do relatório e mil cópias das Observações Astronômicas.

O terceiro volume, impresso em julho de 1856, obteve a autorização do mesmo número de impressões do primeiro volume. Somando mais de quinhentas páginas, Gilliss descreveu e analisou suas observações astronômicas. Neste, o autor também nos contou sobre as origens e operações da expedição.

O quarto volume, curiosamente denominado como o Volume VI, foi impresso em agosto de 1856, e o número de cópias foi o mesmo do segundo volume. Este último ateve-se às observações magnéticas e meteorológicas realizadas no Chile e comparadas com as observações realizadas em Washington, no mesmo período.

Muitos anos depois, em 1895, foi impresso um catálogo que listava as mais de dezesseis mil estrelas observadas durante a expedição de Gilliss, as 
quais deveriam constar nos volumes quatro e cinco. Nesse exemplar, há um relato sobre três fases distintas que compreendem a realização e impressão dos relatórios. Como visto, houve uma interrupção quanto a sequência dos volumes impressos. O volume VI foi impresso antes dos volumes IV e V. No entanto, recebeu tal numeração devido ao fato de Gilliss acreditar que os volumes estariam prontos rapidamente, mas o processo demorou anos, devido aos poucos assistentes envolvidos na computação de dados. Em 1865, ano da morte de James Gilliss e do fim da Guerra Civil norte-americana (1861-1865), o volume quatro estava acabado e pronto para publicação, e o volume cinco encontrava-se quase finalizado. No entanto, o Congresso não liberou fundos para a impressão dos volumes, e, cerca de um ano após sua morte, interrompeu o pagamento de seus assistentes, fato que culminou no fechamento do escritório antes comandado por Gilliss e fazendo com que os manuscritos permanecessem inacabados. ${ }^{28} \mathrm{O}$ que sucedeu após o fechamento do escritório, foi uma ordem do bureau naval para que os documentos fossem guardados no arquivo do Observatório Naval.

Em 1873, o Congresso determinou que essa documentação voltasse a ser catalogada para impressão. Agora, sob o comando do Professor W. M. Harkness, as computações e correções de cálculos foram iniciadas a fim de tornar viável a publicação. O trabalho era grande e o número de assistentes continuou pequeno. Duas décadas se passaram quando, sob o comando dos professores Edgar Frisby e S. J. Brown, conseguiu-se finalmente realizar todas as reduções e correções das observações realizadas por Gilliss e, finalmente, em 1894, os dados foram publicados.

Considerando o período em que Gilliss morreu — no final da Guerra de Secessão - e devido ao período de reconstrução do país, podemos entender que a longa pausa dada na elaboração e publicação desse material não reflete necessariamente falta de interesse por parte do governo. Tratava-se de

${ }^{28}$ GOULD, op.cit.p. 42 . 
priorizar o trabalho de reconstrução que, de 1865 a 1875, concentrou energias em reerguer o país das cinzas da Guerra Civil. Não é por um acaso que o trabalho só ganhou um impulso definitivo na década de 1890 quando os Estados Unidos eram já potência extra-europeia ao lado do Japão e da Rússia.

Assim como a ordem dos volumes não foi impressa de forma linear, o mesmo ocorreu com a ordem da escrita. Gilliss não apresenta uma ordem linear dos acontecimentos em seus relatórios, como veremos nos próximos capítulos dessa tese. 


\section{Capítulo III - O Panamá e o Peru de James Melville Gilliss}

\section{1 - A importância do Panamá na corrida do ouro na Califórnia}

Em 1849, ano em que Gilliss esteve no istmo do Panamá, Colômbia, a cidade do mesmo nome atravessava um período de grande movimentação no porto, devido à "corrida pelo ouro" na Califórnia.

O Panamá, independente da Espanha desde 1821, fazia parte neste período da República de Nova Granada, que agregava a atual Colômbia e parte da região onde hoje é o Equador e Venezuela. O istmo do Panamá, desde o século XVI, chamava a atenção de países europeus interessados em ligar os oceanos Atlântico e Pacífico e com isso, facilitar e aumentar o comércio mundial. Após a Guerra com o México (1846-1848), os Estados Unidos se voltaram para a América Central.

O México perdera metade do seu território ao fim da guerra, inclusive a Califórnia, para os Estados Unidos. A incorporação da região trouxe euforia para aqueles que buscavam riqueza, devido aos achados de ouro. No entanto, o acesso para a Califórnia não era simples. Era necessário encontrar uma forma de ligar a costa leste com a oeste via América Central, evitando a custosa e perigosa travessia via Cabo Horn. Os norte-americanos que se dirigiam à Califórnia muitas vezes tomavam o trajeto de navio até o Panamá na costa do Atlântico, atravessavam de mulas e a barco o istmo até alcançar a costa do Pacífico e de lá tomar o navio para seu destino final. Foi com homens simples que se dirigiam para a Califórnia na Corrida do Ouro que Gilliss compartilhou o navio durante sua viagem ao Panamá. Homens rudes, destituídos de posses ou educação formal, que rumavam ao oeste em busca de riqueza.

Antes de discutirmos as impressões de Gilliss sobre o país, vejamos suas impressões sobre esses norte-americanos que viajaram com ele até o Panamá e também daqueles que encontrou na cidade, durante o período em 
que lá permaneceu à espera do vapor que o levaria até o Chile. No dia 16 de agosto de 1849, Gilliss embarcou no navio Empire City, em direção ao Panamá. Junto com ele, embarcaram duzentos e doze passageiros, cuja grande maioria tinha como ponto final de sua viagem a Califórnia.

Em agosto de 1848, a notícia de que havia sido descoberto ouro na Califórnia chegou a Nova York. O presidente James Polk, após receber um saco com pepitas de ouro, anunciou ao Congresso a descoberta. Nos cinco anos seguintes, cerca de trezentas mil pessoas de várias partes do mundo seguiram para lá, e extraíram aproximadamente 370 toneladas de ouro. Muitas famílias viajaram por terra. No entanto, para os solitários, as viagens de navio eram a melhor opção. Esses homens que embarcaram junto com Gilliss fazem parte de uma geração de aventureiros que se tornaram conhecidos como "the forty-niners". De acordo com Malcolm J. Rohrbough, esta foi a geração que encontrou melhores chances de enriquecer com o ouro, ou com o comércio que se criou nos arredores da maior concentração do metal. ${ }^{1}$

Logo na primeira página em que relatou a viagem, o oficial-cientista já descreveu suas primeiras impressões sobre eles:

No início, era muito "couleur de rosa" [agradável]. Tanto o navio como os passageiros estavam em roupas de festa, mesmo a natureza, embora um pouco ardente, colocava um sorriso no rosto, e, salvo o calor, não se poderia desejar uma mais linda noite. Como o mar estava bastante tranquilo, o mais verde embrião [inexperiente] dos caçadores de ouro corajosamente passeava no convés.[...]

A manhã não trouxe nenhuma mudança de clima, mas as finas vestimentas parcialmente desapareceram, e os homens começaram a aparecer em seu verdadeiro caráter: a maioria dos duzentos e doze sendo aventureiros os quais a porção leste dos Estados Unidos poderia muito bem poupar! É verdade, havia cavalheiros entre eles — isto é, homens cujas consciências controlavam seus atos físicos, mas o número maior ou eram, ou fingiam ser, desasseados, bem

\footnotetext{
${ }^{1}$ Ver: ROHRBOUGH, Malcolm J. Days of Gold: the California gold rush and the American nation. California: California University Press, 1997.
} 
como sem modos. Felizmente, na Era da viagem à Califórnia, ninguém era forçado à intimidade com eles à mesa. ${ }^{2}$

Gilliss descreveu esses homens como mal-educados, grosseiros, e pouco asseados e mal vestidos, e evitou qualquer intimidade com eles. Indicou um dos atributos do homem civilizado: aquele que controla seus atos físicos e emoções. Pertencente a uma classe "diferenciada", julgou seus conterrâneos como indignos de estar em sua companhia. Tal visão do viajante nos mostra a possível imagem que a elite americana do período fazia dos próprios homens pobres norte-americanos. Essa é uma característica notável do relato de Gilliss, pois ele permite compreender como membros da elite norte-americana viam os conterrâneos marginalizados dentro e, no caso, fora do país. Em geral, os viajantes tratavam daqueles de nacionalidade diferente ou grupos indígenas de outras regiões. Preconceituoso, Gilliss promoveu uma reflexão que não estava em sintonia com a política do período, que promovia a corrida para o Oeste e seu consequente povoamento, tão necessário para legitimar e assegurar as regiões recentemente anexadas pelos Estados Unidos. Mas certamente essa visão pejorativa do homem sem posses e sem estudos ia ao encontro com a opinião do público diferenciado que teve acesso a seu relatório. De muitas maneiras, era importante que eles, assim como o governo, tomassem conhecimento de como essa camada da população se portava na sociedade e de como essa população poderia "manchar" a imagem do "civilizado norte-americano".

De acordo com David Goodman, a corrida pelo ouro não foi bem aceita pela sociedade mais afortunada, pois temiam que a ganância transformasse a

\footnotetext{
${ }^{2}$ GILLISS, V1 I, op. cit, p. 401. No original: "At starting, much was "couleur de rose." Both the ship and passengers were in holiday attire; even nature, though somewhat ardent, put on a smiling face, and, save the heat, a more lovely night one could not desire. As the ocean was quite tranquil, the greenest of the embryo gold hunters boldly promenaded the deck. [...] Morning brought no change of weather; but the fine dresses had partially disappeared, and the men began to appear in their true characters; a majority of the two hundred and twelve being adventurers whom the eastern portion of the United States could well spare! True, there were gentlemen among them - that is, men whose consciences control their physical acts; but the larger number either were, or pretended to be, uncleanly as well as unmannerly. Luckily, at that era of California travelling, at table one was not forced into intimacy with them."
} 
região em um local sem ordem, portanto sem pessoas virtuosas. De fato, a busca pelo ouro certamente acentuou a agressividade, a disputa desenfreada e o individualismo. ${ }^{3}$ Gilliss parece expressar o sentimento comum por parte da parcela WASP - branca, anglo-saxônica e protestante — da sociedade norteamericana que colocava à frente das questões políticas, as questões da virtude e do ser "civilizado" e de boas maneiras.

Ao chegar à cidade, sua má-vontade para com essa gente aumentou. Gilliss afirmou que os yankees que lá aportavam manchavam a imagem dos norte-americanos devido ao comportamento agressivo e grosseiro que manifestavam. Em uma dessas passagens, o autor relatou as seguintes cenas que pôde observar durante sua permanência na Cidade do Panamá:

[...] e eu não podia deixar de sentir-me envergonhado em admitir como compatriotas os vagabundos bêbados diariamente encontrados. Seu comportamento, naturalmente, influencia a recepção de todos os americanos, e tão forte já havia se tornado a aversão de alguns panamenhos a nós, que dizer o nome da nação a qual pertencíamos era suficiente para excluir um dos quartos que o proprietário de bom grado teria alugado. E não há remédio para isso. Eles são (soi-disant) [supostamente] cidadãos livres e independentes dos Estados Unidos - um fato que eles acreditam que lhes dá o direito de pisar em qualquer criatura dócil mais fraca; e quando está prestes a sair, podem, se quiserem, cometer incômodos de qualquer natureza nos apartamentos alugados de pessoas inocentes, porque, em verdade, os agentes da empresa de barco a vapor de Nova York não conseguem despachá-los para o (maldito) estado do ouro no dia marcado! De todo modo vergonhoso, essas características não são os únicos sinais de brutalização gerados pela sede ímpia, como a seguir irei mostrar. ${ }^{4}$

\footnotetext{
${ }^{3}$ Cf: GOODMAN, David. Gold seekind: Victoria and California in the 1850s. Stanford: Stanford University Press, 1994.

${ }^{4}$ GILLISS, op. cit., Vol. I, p. 416. No original: [...] "and I could not but feel mortified in acknowledging as countrymen the drunken vagabonds daily encountered. Their behavior, of course, influences the reception of all Americans; and so strong had already become the aversion of some Panameños to us, that the name of the nation to which we belonged was quite sufficient to exclude one from rooms the proprietor would gladly have rented. And there is no remedy for this. They are (soi-disant) free and independent citizens of the United States a fact which they conceive gives them the right to trample on any weaker unresisting creature; and when about to leave, may, if they please, commit nuisances of every description in the rented apartments of unsuspecting people; because, forsooth, the agents of the New York steamboat company fail to despatch them
} 
Note-se aqui aspectos do "homem civilizado": mesmo o oficial acreditando na inferioridade completa dos colombianos, crê que não se deve "pisar em criatura mais fraca". O homem honrado, não empurra para baixo aquele que já se encontra na escala mais baixa da sociedade ou ele não é honrado. Vejamos o que diz do fato de haver encontrado um corpo de um norte-americano na região.

No terceiro dia após a nossa chegada [...] um relato [rumor] corria de que um homem envolto em um cobertor americano, e deitado no alcance de 20 pés da estrada, foi ultrapassado por dois ou três dos grupos. [...] Quem ou de onde ele era não importava para eles nem se ele deveria ser comido por urubus ou vermes. Eles temiam que ele tivesse morrido subitamente por cólera ou outra doença infecciosa, e o abandonaram indigente e sem sepultamento, nem ao menos o examinaram, o que poderia trazer algum alívio aos seus parentes amados, em seu distante lar! Assim que obtive as informações que nos permitiram encontrar o corpo, o Sr. R. e eu imediatamente fizemos arranjos para enterrá-lo.[...] Os nativos tinham mostrado mais humanidade do que seus compatriotas [os norte-americanos]! Relatos chocantes tenho recebido dos egressos da Califórnia, dos miseráveis completamente brutalizados que compõem um grande número dos escavadores de ouro. Eles me asseguram de que existem muitos que não quiseram se desviar [parar] para dar um copo de água a um irmão prestes a morrer, e quanto a enterrar os mortos, era considerado como perda de tempo. ${ }^{5}$

Individualistas ao extremo, brutalizados, tomados pela "sede ímpia", Gilliss sentiu-se envergonhado e revoltado por assistir a homens

to the (accursed) golden country on the appointed day! However disgraceful, these traits are not the only tokens of brutalization generated by the unhallowed thirst, as the following will show."

${ }^{5}$ GILLISS, op. cit., Vl I, p. 416. No original: "On the third day after our arrival, (...) a report was current that a man wrapped in an American blanket, and lying within twenty feet of the road, had been passed by two or three of the parties. [...] Who or whence he was, it mattered not to them- nor whether he should be food for buzzards or worms. They feared he might have died suddenly of cholera or other infectious disease, and left him unknown and unsepultured, without examining for a word which would have served to relieve the agonizing suspense of loving kindred in his distant home! As soon as we had obtained facts that would enable us to find the body, Mr. R. and myself at once made arrangements to go and bury him; [...] The natives had shown more humanity than his fellow-countrymen! Shocking accounts have been given me, by those returning from California, of the utterly brutalized wretches who compose a large number of the golddiggers. They assure me that there are many who would not turn aside to give a dying brother a drink of water; and as to burying dead men, it was regarded as waste of time." 
desumanizados e que sujavam o nome de seu país. Tal excerto oferece a oportunidade de constatar o olhar paradoxal de homem da elite norteamericana para com aqueles que não pertenciam as mais altas camadas sociais. Sem posses, foram retratados por Gilliss como ímpios por sonhar em tê-las.

O oficial não considerou que para além da aventura, a corrida pelo ouro implicava na chance dessa população — mitificada pela sociedade norteamericana moderna em torno da ideia de "homem comum" e do "homem da fronteira", aqueles destemidos que iam adiante domando a natureza e povoando os territórios conquistados — de buscar uma vida melhor. O que Gilliss não comenta é o fato dessa oportunidade ter sido aberta pela mesma elite a qual ele pertencia, particularmente pelo Exército e pela Marinha, que o oficial tanto prezava, na sangrenta guerra que levou os territórios do México e marcou indelevelmente as relações entre Estados Unidos e o país latinoamericano. Mergulhado em contradições, Gilliss frisou que a Califórnia era um "território maldito", mas então por que anexá-la?

Apesar do olhar preconceituoso do autor, podemos inferir que o mau comportamento dos norte-americanos era de fato real. Em 1856, a Cidade do Panamá reagiu a esses desmandos e vivenciou um violento conflito armado entre panamenhos e norte-americanos, conhecido como Guerra da Melancia, originada após um norte-americano ter negado o pagamento por uma fatia de melancia que havia comprado de um panamenho e, na sequência, atirar com sua arma de fogo. Os panamenhos, frustrados com a perda de empregos após a construção da estrada de ferro - cujos cargos foram ocupados por norteamericanos - e revoltados com o mau comportamento dos yankees, acabaram por reagir, deflagrando uma guerra que durou três dias e que ocasionou a primeira intervenção militar do governo norte-americano na região para pôr fim ao conflito, que matou dezesseis norte-americanos e dois panamenhos. A partir desse episódio, os Estados Unidos se esforçaram para 
controlar a região, em associação com os colombianos, formando uma guarda permanente para garantir a paz local e o bom funcionamento da estrada de ferro. Outras treze revoltas foram contidas por militares norte-americanos até $1903 .^{6}$

\section{2 - O Panamá e a sua gente}

Para chegar até a Cidade do Panamá e depois rumar em direção ao Chile, o caminho era árduo. Como disse, o oficial precisou atravessar o istmo. Gilliss aportou próximo ao Rio Chagres e de lá, contratou canoeiros que o levaria até a cidade do Panamá, de onde tomaria outro vapor, até Valparaiso. Ele nos conta que por onde passou, por vezes ouviu dos panamenhos, quando avistava um norte-americano a famosa música cantada pelos "caçadores" do ouro (gold-hunter), como ele os chamava:

\footnotetext{
"O Susannah, don't cry for me;

I'm bound for California

The gold mines for to see"7
}

A viagem até Cruces levou 28 horas. Gilliss pretendia chegar o mais breve possível a seu destino. Enquanto fez a viagem pelo rio, portou-se como um bom e interessado viajante, observando a pobreza das comunidades locais, mas também a beleza da natureza por onde passava. Por vezes era necessário aportar em alguma comunidade, seja por conta das condições de navegação do rio, seja para se alimentarem. Gilliss mostrou-se admirado com a força física e o esforço despendido pelos canoeiros que os levou até Cruces, e expressou gratidão e admiração por tamanho empenho.

Ao aportar em Cruces, observou as "raças": todas as casas pareciam para ele repletas de pessoas, das quais a metade seria de puro sangue africano, e 3/4 dos demais seriam de várias combinações entre espanhóis, índios e

\footnotetext{
${ }^{6}$ Cf: LEONARD, Thomas M. Historical Dictionary of Panamá. Maryland: Rowman \& Litllefield, 2015, p. 281-82.

${ }^{7}$ GILLISS, Op. cit., Vl. I, p. 403.
} 
africanos. Ele afirma que uma oitava parte seria de descendentes dos primeiros espanhóis. Observou também que as mulheres eram mais numerosas do que os homens e estas, pareciam uma "raça" ociosa e descuidada, sentadas na beira das portas de suas casas, com o queixo apoiado nos joelhos. ${ }^{8}$

De Cruces, deveria então seguir viagem por terra, montado em uma mula. Um judeu francês, que, segundo ele, havia aberto mão das facilidades da vida na Europa com o objetivo de servir aos norte-americanos que ali chegavam, o guiou por terra até a Cidade do Panamá. O percurso era perigoso e acidentado, e Gilliss resolveu confiar na mula que o carregava, durante as horas que se seguiram até a chegada em seu destino final.

Após quatro dias de viagem, somando todo o percurso, desde Chagres, Gilliss finalmente chegou à Cidade do Panamá. Dentre as observações feitas, novamente as raciais, de imediato, chamam à atenção. Ao comentar sobre o estado deplorável das construções antigas, Gilliss culpou a "raça indolente" pelo estado em que as mesmas se encontravam. ${ }^{9} \mathrm{E}$ ao descrever os trabalhadores, a maioria negros, afirmou:

Eu já comentei sobre o número de pessoas que provavelmente habitam a cidade e o seu entorno. Quantos destes são permanentemente ocupados com o comércio seria difícil de determinar, mas não há dúvida de que o fluxo de americanos aumentou sensivelmente a demanda por produtos nacionais; há poucos carpinteiros, alfaiates, sapateiros, chapeleiros, etc., que para tanto cobram exatamente cem por cento a mais por seus produtos do que o custo da mesma classe de artigos nos Estados Unidos. ${ }^{10}$

\footnotetext{
${ }^{8}$ Cf. GILLISS, op. cit., Vl.I, p. 408.

${ }^{9}$ Cf. GILLISS, op. cit., V1 I, p. 412.

${ }^{10}$ GILLISS, op, cit. Vl. I, p. 415. No original: "I have said what number of people probably dwell within and about the city. How many of these are permanently occupied in trades it would be difficult to ascertain; yet there is no doubt that the influx of Americans sensibly increases the demand for domestic products; and carpenters, tailors, shoemakers, hatters, \&c., have each a few representatives, who both ask and exact quite a hundred per cent, more for their fabrics than the same class of articles cost in the United States."
} 
Gilliss salientou a importância do comércio, reclamou dos altos preços, afirmou que a presença dos norte-americanos ajudou a região, ao mesmo tempo em que alertou para o fato de que eram poucos os que se dedicavam aos serviços especializados. Mas o interessante são os argumentos do viajante para explicar essa situação.

A principal causa disso é a indolência absoluta de trabalhadores negros. Estes compõem uma grande parcela da classe trabalhadora, e não estão dispostos a trabalhar um momento depois de terem obtido suficiente para satisfazer os seus apetites durante dois ou três dias. Por conta disso, licores intoxicantes são vendidos em cada terceira ou quarta casa, e essas lojas recebem mais da metade dos ganhos dos mecânicos. Um pouco de arroz, inhame ou iúcas e frutas nativas, são todos os alimentos de que necessitam. Com a abundância de tais alimentos baratos, uma garrafa de rum ou conhaque do país, um maço de cigarros, eles refestelam sobre o chão ou em redes até que o suprimento de dinheiro se vá, e a fome os obrigue a trabalhar de novo. E mesmo assim, se eles puderem obter as cargas para transportar sobre os seus ombros, o que normalmente requer pouco trabalho e carregamento rápido, bem como grande recompensa, eles não vão para seus ofícios. Aparentemente, as mulheres estão mais inclinadas a serem trabalhadoras; mas, sob a influência de um clima enervante, um grande número delas aprecia plenamente o "dolce far niente" [ociosidade agradável]. ${ }^{11}$

O que acabamos de ler acima, infelizmente, é uma descrição bastante comum dos negros entre os viajantes europeus e norte-americanos e também sul-americanos, como por exemplo Salvador Camacho Roldán e Juan Bautista Alberdi. Gilliss era um homem da ciência e nos Estados Unidos da primeira

\footnotetext{
${ }^{11}$ GILLISS, op. cit., Vl. I, p. 415-16. No Original: " One principal cause of this is the absolute indolence of negro laborers. These compose a large proportion of the working class, and are unwilling to work one moment after they have obtained sufficient to gratify their appetites during two or three days. On this account intoxicating liquors are sold in every third or fourth house, and these shops receive more than half the earnings of mechanics. A little rice, yams or yuccas, and native fruits, are all the food they require. With plenty of such cheap sustenance, a bottle of country rum or brandy, and a bundle of cigars, they loll about the floors or in hammocks until the supply of money is gone, and hunger forces them to work again. Even then, if they can obtain loads to carry on their shoulders, which ordinarily requires brief labor and brings prompt as well as large recompense, they will not go to their trades. Apparently, the women are more inclined to be industrious; but, under the influence of an enervating climate, a very large number of them fully appreciate the "dolce far niente."
} 
metade do século XIX, o estudo sobre as raças e os efeitos do clima em diferentes partes do globo vinha sendo amplamente estudado e difundido entre as classes científicas, principalmente a partir da American Ethnological Society $^{12}$. Vejamos então as ideias que circulavam no período.

Como já abordado por mim em pesquisa anterior ${ }^{13}$, George Stocking afirma que os problemas em torno da questão das origens dos homens ao longo do século XIX, foram alimentados, entre outros aspectos, pelo crescente número de relatos sobre a diversidade biológica, oferecidos por viajantes que rodaram o mundo descrevendo tais diferenças. ${ }^{14} \mathrm{Na}$ primeira metade do século XIX, os estudos etnológicos, amplamente divulgados nas instituições científicas, buscavam explicar as diferenças raciais e muitas vezes, legitimar o preconceito e o lugar de inferioridade que os não-brancos assumiam nas sociedades ${ }^{15}$. O Novo Mundo, pelo seu clima quente e “degenerador" e pela população indígena, negra e mestiça, eram para muitos desses homens o lugar da degeneração física e moral e consequentemente, do atraso. Tais ideias não eram novas, como nos conta Antonello Gerbi, em seu clássico estudo sobre o Novo Mundo, em que apresenta diversas teorias que buscavam explicar a suposta inferioridade da natureza e dos habitantes dos trópicos, mencionadas por pensadores europeus. Gerbi afirma que a relação feita entre clima e gênio foi extremamente comum na Antiguidade, e se estendeu por séculos. Segundo o autor, antes de Buffon (século XVIII), já se encontravam aqui ou ali, referências negativas sobre a natureza da América e a degeneração do homem, ligadas especialmente ao clima, e tal ideia foi tomando corpo ao longo dos séculos seguintes:

\footnotetext{
${ }^{12}$ Para informações mais aprofundadas sobre a etnologia e sua relação com o clima e as diferentes "raças" no globo, Cf: PAULINO, Carla Viviane. O império do atraso: Etnologia, Política e religião nas impressões sobre o Brasil de um inglês radicado nos Estados Unidos (1846-1856). São Paulo: Alameda, 2015.Capítulo 2.

${ }^{13}$ Ibidem, cap. 2

${ }^{14}$ STOCKING, George. Victorian Anthropology. New York: The Free Press, 1991, p.49.

${ }^{15}$ PATERSON, T. Carl. A social History of Anthropology in the United States. Oxford \&NY: Berg Publishers, 2001, p.3.
} 
O "clima", em particular, servia para mediar o abismo lógico entre a tese da debilidade física do continente americano e a de sua inferioridade civil e política. Era apenas um fator, mas um fator crucial que permitia esboçar uma explicação unitária de uma infinidade de fatores geográficos e históricos. ${ }^{16}$

No século XIX, essas teorias ganharam força e passaram a ser legitimadas pelas instituições científicas e universidades, e um fator impulsionador para aquecer tais discussões nos Estados Unidos estava relacionado à iminente extinção de várias tribos indígenas e a questão da escravidão; no século XIX, tanto os interessados em aboli-la, como aqueles que pretendiam mantê-la, recorreram mais e mais à ciência no intuito de legitimar determinados interesses e justificar as suas ações. Nos Estados Unidos, a primeira instituição a discutir o tema foi a American Philosophical Society, fundada em 1745 por Benjamin Franklin, com o objetivo de promover conhecimento nas áreas das ciências e humanidades em geral. Gilliss era membro desta instituição.

O oficial cientista, como vimos no excerto, relatou que os negros panamenhos eram preguiçosos dedicados aos vícios, como a bebida e o cigarro. Ainda afirmou que, embora as mulheres negras parecessem mais industriosas, o clima "enervante" as impedia, de certa forma, de produzir mais. Sem ambições, trabalhavam o suficiente para comer e alimentar tais vícios. Essas associações entre clima, raça, degeneração e ociosidade são típicas das teorias etnológicas do período, assim como também faziam parte do estereótipo racial comungado entre os brancos norte-americanos em geral.

Embora o autor não utilize de argumentos científicos para embasar sua visão, acredito que, pelo meio social elitista e científico em que estava inserido em seu país, suas representações foram sustentadas pela soma dos

\footnotetext{
${ }^{16}$ GERBI, Antonello. O Novo Mundo: História de uma polêmica: 1750-1900. São Paulo: Companhia da Letras, 1996, p.48.
} 
preconceitos raciais e dos debates que ocorriam nos Estados Unidos no período em questão.

Devemos lembrar que, embora o enfoque de Gilliss fosse a Astronomia, as instituições científicas do período, as quais ele frequentava, tratavam de assuntos diversos e na década de 1840, estudos sobre a "raça" negra eram bastante populares naquele país, como pude observar.

Ao longo da análise de seu relatório de viagem, veremos que por onde Gilliss encontrou negros, deles falou com desprezo e preconceito, colocandoos em um lugar de inferioridade que fluem em seu texto com naturalidade. Como vimos, a ciência, assim como a população comum, havia legitimado o lugar do negro em sociedade. Seja como escravo, seja como homem livre, este seria sempre inferior ao homem branco. Mas em sua descrição no excerto acima, ao culpar os negros pelo alto preço e escassez de produtos e serviços, Gilliss deixou passar o aspecto econômico e a lei de oferta e procura. A cidade do Panamá, como ele afirmou, oferecia serviços a preços extremamente altos, fato que o viajante atribuiu a culpa aos negros e não ao mercado. Em uma cidade tomada por viajantes, é natural o aumento dos preços dos serviços. Os panamenhos lucraram no período em que o viajante por lá esteve; assim, sob o meu ponto de vista, não se tratou de preguiça, mas de poderem optar quando e para quem trabalhar em um momento em que a grande oferta de trabalho possibilitou a escolha. Todos nós sabemos também que negros e brancos pobres trabalham e trabalharam muito, mas talvez não na esfera lucrativa formal que o viajante valorizava.

\subsection{1 - Os Padres e suas "sobrinas"}

Depois dos negros, chegou a vez de Gilliss comentar sobre a conduta dos padres católicos do Panamá:

O padre bate às portas de sua congregação, às três horas da manhã do sábado, e as mulheres o acompanham; um costume, creio eu, 
peculiar do Panamá. O hino que cantam em sua marcha é doce e melancólico, e no silêncio calmo da noite a multidão de vozes deve fazer pensar sobre um mundo melhor. Mas mesmo o padre tendo influência suficiente com certas classes a ponto de trazê-las para estas horas impróprias, não é capaz de inculcar os seus preceitos, nem seus exemplos inspiram reverência ao santo dia, e todo domingo de manhã, pode-se encontrar lojas abertas e mulheres costurando em portas adjacentes à própria catedral. ${ }^{17}$

Primeiro os negros, agora a religião católica é um problema que grassa na Colômbia, em razão da devoção, sem discernimentos, dos fiéis. Gilliss credita à religião uma das causas do "atraso" das sociedades latinoamericanas. Pior que a religião em si, só mesmo a atuação e o comportamento dos padres.

É muito lamentável que os ministros do evangelho aqui não possuam todos caráteres irrepreensíveis. Mais do que um, notoriamente frequentam a tabela de jogo pública em um restaurante, no domingo, e eu vi outro entrar na rinha de galos, no mesmo dia, tendo seu pássaro permanecido amarrado pela perna na porta da igreja até a conclusão da missa da manhã. Além disso, a minha senhoria, que é de boa família e bem-educada, me diz que seu tio, um cânone, tem dois filhos, um dos quais está na casa com a gente, e que o padre em Taboga tem a fama de ter contribuído para a adição de quatorze a sua população no ano passado! O número é provavelmente exagerado, mas não há dúvida de que ele tem muitas "responsabilidades" em torno de sua igreja [...]. ${ }^{18}$

\footnotetext{
${ }^{17}$ GILLISS, op. cit., V1. I, p. 414. No original: "The priest knocks at the doors of his congregation at three o'clock every Sabbath morning, and the females accompany him; a custom, I believe, peculiar to Panama. The hymn they sing in their march is sweet and plaintive; and in the calm silence of the night the multitude of voices should make one think of a better world. But whilst the priest has sufficient influence with certain classes to bring them out at these unseasonable hours, neither do their precepts inculcate nor their examples inspire reverence for the holy day; and all Sunday morning one may find shops open and women sewing at doors adjoining the cathedral itself."

${ }^{18}$ Cf. GILLISS, op. cit. V1. I, p. 414. No original: "It is greatly to be regretted that the ministers of the gospel here do not all possess characters without reproach. More than one notoriously frequented the public gambling table, at a restaurant, on Sunday; and I have seen another enter the cock-pit on the same day, his bird having remained tied by the leg at the church door until the conclusion of morning mass. Moreover, my landlady, who is of good family and well educated, tells me her uncle, a canon, has two children, one of whom is in the house with us, and that the padre at Taboga is reputed to have been instrumental in adding fourteen to its population last year! The number is probably exaggerated; but there is no doubt that he has many "responsibilities" around his church "[...].
} 
Gilliss se manteve respeitoso diante dos rituais da Igreja, como guardar o domingo, não tecendo comentários sobre a religião em si. No entanto, demonstrou que os fiéis mais fervorosos eram compostos por mulheres e estas, das classes mais baixas. Na sequência, ressaltou o comportamento imoral de alguns padres, que não só deixavam de vivenciar o domingo como dia santo, ao contrário do que a Igreja católica prega, como também possuíam famílias. As chamadas "sobrinhas" que costumam habitar junto aos padres em algumas comunidades eram comuns no Panamá, como afirmou o autor.

Esse olhar crítico da Igreja Católica nos trópicos é comum entre os viajantes norte-americanos, especialmente os de religião protestante. Em um ambiente que, por seu clima e predomínio de "raças inferiores", era degenerador, os padres e a Igreja trilhavam o mesmo caminho.

Para boa parte dos protestantes, a religião católica, principalmente a dos trópicos, havia perdido seus princípios fundamentais e se degenerado, a começar pela figura de seus principais representantes. $\mathrm{O}$ autor se vale aqui da fala do outro — da sua senhoria — uma local, que, na perspectiva do viajante, conhece e confirma o status de verdade daquilo que o viajante retrata. Além das suas próprias impressões, Gilliss utiliza de outros dispositivos, como o testemunho de terceiros, mas aqueles que obviamente confirmam os seus argumentos e impressões.

\subsection{2 - Os interesses geopolíticos e econômicos}

Gilliss não atravessara o istmo, em viagem desagradável, segundo o que já vimos aqui, sem motivo. Vimos que a região chamava a atenção de investidores e de países interessados em ligar os oceanos Atlântico e Pacífico e que os Estados Unidos voltaram seu olhar com mais atenção para a região após a Guerra com o México, justamente pela possibilidade de alcançar o Pacífico, evitando-se a difícil travessia pelo Cabo Horn. 
Sobre a possibilidade de investimentos por parte dos norte-americanos na cidade, o autor afirma que "na verdade, não pode mais ser posto em dúvida que a indústria americana e o capital norte-americano serão amplamente empregados aqui dentro de cinco anos". ${ }^{19}$ Aqui vemos já a descrição de possibilidades de investimentos, tanto os de grande como os de pequeno porte para os norte-americanos e também mais um indício dos objetivos comerciais na expedição astronômica, que apesar de ser fundamentalmente científica, carregava, como dissemos, diversos objetivos alheios.

Em seu relatório, observamos que o autor fez contatos com empreendedores norte-americanos que já faziam investimentos na região. $\mathrm{O}$ nome mais citado por ele é o de William Wheelwright, fundador da Pacific vapor Navigation Company, a primeira companhia de navegação a vapor do Pacífico. Já na década de 1820 Wheelwright iniciou seus investimentos em linhas de vapores na região de Guayaquil, no Equador, então parte da Gran Colômbia, local em que também assumiu o cargo de Cônsul dos Estados Unidos. Seus negócios pela região iniciaram com o transporte de cargas, cartas e passageiros, inicialmente entre os portos sul-americanos e, posteriormente, seus negócios foram ampliados e os navios passaram a viajar aos Estados Unidos e à Europa, para embarcar encomendas e pessoas para a América do Sul. Este empreendedor, em fins dos anos 1830, interessado em diversificar seus empreendimentos, buscou financiamento para a construção de uma linha férrea ou marítima no Istmo do Panamá.

No período em que Gilliss esteve na região, Wheelwright já havia estendido sua linha de navegação para vários portos da América do Sul, incluindo o Panamá. Em 1846, havia construído uma estrada de ferro interligando Caldeira-Copiapó, no Chile. No momento em que esteve em contato com Gilliss, ele estava interessado na construção de uma estrada de

\footnotetext{
${ }^{19}$ GILLISS, op. cit., Vl. 1, p. 415. No original: "In fact, it can no longer be doubted that American industry and American capital will be largely employed here within five years."
} 
ferro que interligasse o Chile, a partir de Valparaiso, até Buenos Aires. Vale mencionar que ele buscou financiamento com os ingleses, e não norteamericanos. No entanto, a ideia de construir uma estrada de ferro ligando Valparaiso-Buenos Aires acabou por se provar inviável, devido ao alto custo e aos empecilhos geográficos quase impossíveis de se transpor para tornar a construção da ferrovia possível naquele período.

Voltando ao Panamá, na década de 1840 verificamos a existência de outros norte-americanos interessados em construir uma estrada de ferro na região do istmo. Em 1847 um grupo de investidores de Nova Iorque começou a planejar a sua construção, cuja sociedade posteriormente deu forma a chamada Panamá Railroad Company. William Aspinwall foi o principal nome nesta empreitada, pois foi capaz de vender a ideia e conseguir os contratos para a sua construção. Em conjunto com os seus sócios, John Stephens e Henry Chauncey, eles celebraram um contrato com o governo de Nova Granada para a construção de uma estrada de ferro através do istmo do Panamá em 15 de abril de 1850, o qual concedeu à empresa o privilégio exclusivo de construí-la e de operá-la por um período de 49 anos a partir da data de conclusão. Foi estipulado que a construção não deveria ultrapassar um período de seis anos. Os erros de cálculo foram muitos, e a empreitada tornou-se mais difícil do que qualquer profissional envolvido poderia prever. Muitos homens perderam suas vidas durante a construção da estrada, e os embates políticos e culturais foram tensos durante e após esse período. Depois de muito esforço e vidas perdidas, a ferrovia estava finalizada e o primeiro trem fez seu trajeto em janeiro de 1855.

A corrida do ouro teve grande influência no que diz respeito a este empreendimento e por isso obteve apoio norte-americano em suas negociações junto ao governo de Nova Granada. Em meados da década de 1840, o governo norte-americano, preocupado com a expansão britânica ao longo da costa da América Central, incluindo o uso do porto de Chagres na 
costa norte do Panamá, onde canoas e mulas transportavam mercadorias e pessoas, tal como ocorrera com Gilliss para chegar até a Cidade do Panamá, buscou soluções para diminuir o domínio britânico na região. Para tanto, o presidente James K. Polk enviou o político Benjamin Bidlack para Bogotá, com a finalidade de negociar um tratado com a Grã-Colômbia, no qual em troca de conceder aos Estados Unidos direitos de livre acesso através do istmo do Panamá por qualquer meio necessário, este por sua vez, ajudaria a GrãColômbia, caso fosse preciso, a manter sua soberania sobre o istmo do Panamá. Desta forma, ratificaram então o Tratado Bidlack-Mallarino, em 1846. Oficialmente o nome dado a este foi Tratado de Paz, Amistad, Navegación y Comercio.

$\mathrm{O}$ impacto imediato do Tratado resultou na concessão de direitos à Marinha dos Estados Unidos para transportar correios e pessoas entre os Estados Unidos e o Panamá. O Tratado Bidlack-Mallarino também abriu o caminho para a estrada de ferro do Panamá, cujo contrato garantiu a permissão de operar com funcionários dos Estados Unidos e de controlar sua própria força de segurança. O Tratado também forneceu a cobertura legal para 14 intervenções militares dos Estados Unidos a fim de restaurar a ordem, desde a Guerra da Melancia, em 1855, até a Guerra dos Mil Dias, 1899$1902 .{ }^{20}$ Vale lembrar que em 1850, Estados Unidos e Inglaterra assinaram o Tratado Clayton-Bulwer, que impedia que um ou outro país construísse canais interoceânicos ou colonizassem os países da América Central. No entanto o Tratado de 1846 já dava aos Estados Unidos direitos de investir em vias férreas ou interoceânicas e até mesmo de intervir militarmente no Panamá, no caso da necessidade de proteção da estrada de ferro e dos norte-americanos, como acabamos de ver. Assim, o Tratado Clayton-Bulwer firmado com a

\footnotetext{
${ }^{20}$ Cf: LEONARD, Thomas M. Historical Dictionary of Panamá. Maryland: Rowman \& Litllefield, 2015.pp.281-82.
} 
Inglaterra em 1850, não impediu os Estados Unidos de firmarem sua supremacia nos países da América central.

Para o Panamá, o crescente número de pessoas que chegavam para atravessar o istmo trouxe prosperidade. Entre 1848 e 1869, cerca de 375 mil pessoas atravessaram o istmo do Atlântico para o Pacífico, e 225 mil cruzaram o trajeto em direção oposta. ${ }^{21}$ Os preços para alimentos e serviços foram muito inflacionados, como o próprio Gilliss observou em seu relatório, produzindo enormes lucros obtidos através de refeições, produtos manufaturados e alojamento.

Ao tomar conhecimento dos investimentos realizados na região por norte-americanos, e do Tratado compactuado entre Estados Unidos e Nova Granada, sua volta pelo mesmo local se torna compreensível. Quando Gilliss passou pelo Panamá novamente em 1852, a construção da via férrea já estava em andamento há dois anos. Embora o viajante não mencione este dado em seu relatório, acreditamos que ele serviu como "olhos" do governo, que certamente o instruiu para verificar e relatar o andamento das obras e o cumprimento do Tratado.

A presença da Marinha americana e de ações militares no local, conquistadas com o tratado já citado demonstram os interesses por parte do governo em assegurar sua influência em uma região extremamente estratégica e de grande potencial econômico.

Apesar de tais empreendimentos serem liderados por norte-americanos, investidores ingleses financiaram várias construções feitas por Wheelwright, como já dito. O Tratado, como vimos, abriu caminho para empreendedores norte-americanos que conseguiram firmar os contratos para obras de grandes construções ligadas ao transporte marítimo e terrestre, mas houve grandes investimentos por parte de capitalistas ingleses, como bem demonstrou o liberal argentino radicado no Chile, Juan Baptista Alberdi, que escreveu um

\footnotetext{
${ }^{21}$ Panama. A Country Study .Washington, DC: The Library of Congress, 1989.
} 
livro sobre as benfeitorias realizadas por Wheelwright e outros norteamericanos na América do Sul. ${ }^{22}$ Essa parceria entre civis norte-americanos e ingleses, que investiram juntos principalmente no Chile, sob meu ponto de vista, explica a tolerância por parte da Inglaterra com relação à atuação dos Estados Unidos no istmo do Panamá. ${ }^{23}$

\section{3 - Do Panamá para Lima}

No dia 27 de setembro, Gilliss finalmente conseguiu embarcar no vapor New Grenada ao meio dia, junto a outros vinte e três passageiros. O destino final era Valparaiso, no Chile, mas o navio realizaria algumas paradas em portos da Colômbia, Equador e Peru. Como veremos abaixo, o autor procurou descrever os lugares que visitou rapidamente. Sua preocupação era registrar as latitudes, a geografia, a população e o comércio.

Durante o percurso em direção ao primeiro porto, Gilliss narrou a viagem, atento ao clima e aos peixes que lhe causaram satisfação em observar, como os vários botos e peixes-voadores que acompanhavam o navio durante a tarde. Em 29 de setembro, ao pôr do sol, o navio adentrou na foz do rio Buenaventura, na Colômbia, e ancorou às margens da cidade de mesmo nome. Gilliss afirmou que este era o porto mais próximo para os passageiros e para a entrega do correio que chegava de e para Bogotá. Sobre o local, o viajante pouco pode dizer, já que não foram autorizados a desembarcar. Tal proibição se deveu à prevenção da cólera e, portanto, o navio o qual Gilliss embarcara estava em quarentena. No entanto, Gilliss comentou que passageiros novos embarcaram.

\footnotetext{
${ }^{22}$ Alberdi, embora teça críticas aos Estados Unidos, escreveu um livro sobre William Wheelwright no qual reconhece que ele e outros do norte dos Estados Unidos foram os responsáveis em trazer progresso para a América do Sul. Cf: ALBERDI, Juan Bautista. La vida y los trabajos industriales de William Wheelwright en la América del Sud. Paris: Libreria de Garnier Hermanos, 1876.

${ }^{23}$ Sobre este tratado e os desdobramentos políticos e econômicos aqui mencionados, Cf: VARGAS, Diego Uribe. Colombia y la diplomacia secreta:1321-1850. Bogotá: Colección Bolsilibros de la Academia Colombiana de Historia, 1973.
} 
No dia seguinte, ao passar pela Ilha de Gorgona, ainda na Colômbia, o oficial a descreveu da seguinte forma:

\begin{abstract}
A ilha é pequena, embora coberta com vegetação, e é extremamente pitoresca e bonita. Tem uma boa baía do lado sudoeste, com abundância de água, e tem a fama de possuir uma valiosa mina de ouro, bem como uma pescaria de pérola de grande medida nas águas adjacentes. A dificuldade de acesso e répteis venenosos impedem o primeiro de ser trabalhado, e multidões de tubarões vigiam o último, prontos para devorar todos os mergulhadores que podem procurar suas joias. Pelo menos essa é a história contada sobre o tesouro. ${ }^{24}$
\end{abstract}

Aqui notamos uma observação sobre as possíveis fontes de riqueza locais, pouco exploradas pela natureza ameaçadora da ilha. De fato, a região era e ainda é rica em pérolas e minérios. Mas em sua descrição há também um certo tom que mistifica o local, típico de relatos sobre as ilhas e mares do Pacífico desde antes do início das grandes navegações.

Durante sua estadia no Panamá e todo o percurso até o Chile, Gilliss inúmeras vezes relatou informações das quais sequer cita as fontes, postura comum ao período. Apesar dos dados geográficos e da possibilidade de riquezas locais, não há certezas sobre muito do que por ele é relatado. Isso nos remete a outro aspecto importante dos relatos ou relatórios de viagem: a sua imprecisão ou mesmo, em muitos casos, a falta de veracidade em muitas situações. Mesmo em um relatório oficial da U. S. Navy, notamos que isso ocorreu, como no caso desta expedição. Lembremos, no entanto, que no século XIX, a noção de veracidade era diferente da praticada atualmente. Uma informação de terceiros, seja através de relatos orais diretamente ao viajante, ou de leituras que o mesmo fazia de outros viajantes sem citá-los, era

\footnotetext{
${ }^{24}$ GILLISS, op., cit., Vol. I, p. 421-22. No original: "The island is small, though covered with vegetation, and is extremely picturesque and beautiful. It has a good bay on its southwest side, with abundance of water, and is reputed to possess a valuable gold mine, as well as a pearl fishery of great extent in the adjoining waters. Difficulty of access and venomous reptiles prevent the former from being worked, and multitudes of sharks keep watch over the latter, ready to devour all divers who may seek their gems. At least such is the story told on hoard."
} 
considerada legítima e podia, como de fato o era, ser tomada como verdade. No caso de Gilliss ao longo do relatório notamos que ele se valeu de fontes orais e de escritas por cientistas ou viajantes da U.S. Navy. No entanto, é visível a influência de norte-americanos que residiam nos locais por onde passou. Cabe aos estudiosos do período atual, tomar os devidos cuidados com este tipo de fonte, pois embora sejam muito ricas em informações, não é possível tomá-las como retrato fiel de um tempo ou lugar.

Outro aspecto recorrente durante sua passagem ao Peru e Colômbia, é a citação de Francisco Pizarro. Após partirem de Buenaventura, ao citar a Isla Del Gallo, Gilliss informa ao leitor que lá, Pizarro fez seu estande famoso, oferecendo a todos os que procuraram o Peru, para obter fama, fortuna e prazer, a segui-lo através de uma linha traçada na areia com a ponta da espada. $^{25}$

Neste excerto e em muitos outros, o viajante demonstrou conhecimento prévio da história da colonização e invasão da região, mas, como veremos, até se despedir do país pouco se interessou pela história dos que foram colonizados, deixando de relatar, por exemplo, a civilização e cultura incaicas, tão importantes, como sabemos. Esse descaso leva a inferir sobre o olhar de Gilliss, que ao omitir a história dos locais, lhes conferiu um lugar de inferioridade em relação aos colonizadores europeus. $\mathrm{O}$ que podemos avaliar como peculiar nesse viajante é sua coragem em criticar também seus conterrâneos, como vimos no Panamá.

Em três de outubro, já no Equador, o navio avistou o Porto de Santa Elena, na costa norte do Golfo de Guayaquil. Assim como nos portos anteriores, um pequeno vapor do governo chegou até o navio com a missão de impedir que aportassem, com o mesmo temor de que carregassem a cólera para a cidade, o que instigou o comportamento de Gilliss diante dessas negativas. $\mathrm{O}$ viajante demonstrou irritação ao se deparar com uma situação

${ }^{25}$ GILLISS, op. cit., Vol. I, p. 422. 
que seria facilmente inquestionável nos Estados Unidos, diante de uma epidemia:

O medo de que poderíamos introduzir a cólera tinha infectado seriamente as autoridades desta perniciosa e pestilenta cidade. Além do correio, havia cerca de uma dúzia de passageiros e alguns fretes a bordo para o Equador, todos os quais, exceto as cartas, foram ordenados a se manterem a bordo. Entre os passageiros estava um Encarregado de assuntos comerciais dos Estados Unidos, acreditado junto ao governo do Equador, em cujo nome foi feito um sério protesto pelo capitão do nosso navio; mas [o oficial] impiedosamente disse: "Se você Jesus Cristo estivesse a bordo, eu atiraria em você, se você tentasse desembarcá-lo." [...] Embora as pessoas a bordo que tinham negócios aqui fossem colocadas em grande incômodo e despesa ao serem levadas para o próximo porto onde o navio iria ancorar, todos reconheceram a santidade das leis de quarentena $[\ldots] .{ }^{26}$

Foi somente no Peru que a "sorte" dos passageiros começou a mudar. Em quatro de outubro chegaram ao Porto de Payta e lá receberam permissão para aportar e descer em terra firme. Ao chegarem próximo ao local, Gilliss vai delineando-o como área comum a determinados trabalhadores norteamericanos, os baleeiros:

\begin{abstract}
Apenas no pôr do sol o navio ancorou no meio de meia dúzia de baleeiros americanos no porto de Payta. Eles estavam aqui para reparações ou fornecimentos de legumes. Três outros deixaram o porto que entramos, para voltarem para casa, ou talvez prosseguir o trabalho perigoso que os havia trazido para o Pacífico Sul. ${ }^{27}$
\end{abstract}

\footnotetext{
${ }^{26}$ Cf: GILLISS, op. cit., Vol. I, p. 422-23. No original: "Fear that we might introduce the cholera had thus seriously infected the authorities of this noisome and pestilential town. Besides the mail, there were nearly a dozen passengers and some freight on board for Ecuador all of which, except the letters, we were commanded to keep on board. Among the passengers was a United States Chargé d'Affaires accredited to the government of Ecuador, in whose behalf remonstrance was earnestly made by the captain of our steamer; but he waspiously told, "If you had Jesus Christ himself on board, I would fire into you if you attempted to land him." [...] Although those on board who land business here would be put to great inconvenience and expense by being carried on to the next port where the steamer would anchor, all recognised the sanctity of the quarantine laws..."

${ }^{27}$ GILLISS, op. cit., Vol. I, p. 423. No original: "Just at sunset the ship anchored amid half a dozen American whalers in the harbor of Payta. They were here for repairs, or supplies of vegetables. Three others left the
} 
Após elogiar a coragem e bravura dos americanos que desafiavam os perigos de um oceano pouco conhecido, Gilliss prosseguiu a narrativa apontando a facilidade com que obtiveram a permissão para aportar em Payta, frisando que, desta vez, o agente de saúde era um yankee:

O oficial da saúde (o qual, aliás, era um yankee) esteve sempre ao lado enquanto a âncora era baixada; e, com alguns breves questionamentos, vindo a bordo, ele disse: "examinar nossas doenças". Não encontrando tais infortúnios, nós fomos imediatamente admitidos a todos os privilégios da famosa cidade das baleias; pois elas, provavelmente, contribuíram mais com seu comércio e prosperidade, do que em qualquer outra porção do mercado mundial. Muito para um grão ou dois de sentido claro, senso prático e poderes discricionários razoáveis creditados a um descendente de anglo-saxões. Um peruano teria provavelmente nos recusado a pratique [a prática], conhecendo o tratamento em Buenaventura ou Guayaquil, e seguramente implicado quarentena em todos os outros portos na costa, simplesmente porque seus oficiais de saúde tinham sido tão absurdos. ${ }^{28}$

Neste excerto, Gilliss atribui a permissão e facilidade de entrada na cidade pelos passageiros ao fato de o agente de saúde ser um prático e esclarecido "yankee", como está claro. Mais, ele atribui o sucesso comercial de Payta ao grande número de baleias na região, as quais eram caçadas por baleeiros norte-americanos, que implicavam em um grande fluxo comercial para a cidade. Para o oficial, isso se tornara possível não devido aos acordos comerciais entre países, mas sim pelo fato de que quem controlava a entrada de navios ser um anglo-saxão e não um peruano que, a seu ver, agiria como os

port as we entered, bound home, or perhaps to pursue the perilous employment that had brought them to the South Pacific."

${ }^{28}$ GILLISS, op. cit., Vol. I, p. 424. No original: "The health officer (who, by-the-by, was a Yankee) was alongside by the time the anchor was down; and, with some brief questions, came on board, he said, "to examine our sick." Finding no such unfortunates, we were at once admitted to all the privileges of the renowned city of the whalers; for they have probably contributed more to its commerce and prosperity than any other portion of the trading world. So much for a grain or two of plain, practical sense, and reasonable discretionary powers intrusted to a descendant of the Anglo-Saxons. A Peruvian would probably have refused us pratique on learning the treatment at Buenaventura and Guayaquil, and would assuredly have entailed quarantine at all the other ports on the coast, simply because their health-officers had been so absurd." 
agentes do Equador e da Colômbia, inviabilizando assim o fluxo no porto e na cidade. Há que se lembrar aqui, como vimos, que a região sofria com a cólera e outras doenças, mas Gilliss preferiu ignorar tal fato, seja por vontade própria ou por ordens vindas de seus superiores. O fato é que a praticidade anglo-saxã (e sua negligência com relação à cólera), no país alheio, tornou-se mérito para Gilliss.

Embora o oficial não aceitasse bem a situação, vejamos o que ocorrera nessas regiões que tão veementemente recusaram-se a correr riscos de novas contaminações.

A cólera, assim como muitas outras doenças, chegava às cidades através de visitantes que vinham principalmente por mar. No ano de 1849, ou seja, no mesmo período em que o oficial passou pelo Equador, a cidade de Cartagena estava sendo devastada por essa enfermidade. Estima-se que cerca de um quarto da população morreu em apenas onze semanas ${ }^{29}$. Sem saber com exatidão as formas de contágio da doença, preocupavam-se em evitar o trânsito de pessoas sempre que um surto se manifestava, como no ano de 1849.

Nos Estados Unidos, no mesmo ano de 1849, uma grande epidemia de cólera também assolou varias cidades, principalmente as localizadas na região centro-oeste. O número de mortos chegou a $10 \%$ da população em cada cidade, muito embora esse seja um dado estatístico. De acordo com Walter Daly, em muitas pequenas cidades os números de mortos ultrapassaram 50\% da população. ${ }^{30}$

De acordo com Maria Almeida, que realizou ampla pesquisa sobre os surtos de cólera em vários momentos do século XIX, incluindo 1849, ano em

\footnotetext{
${ }^{29}$ Cf: ALMEIDA, Maria Antónia Pires de. As epidemias nas notícias em Portugal: cólera, peste, tifo, gripe e varíola, 1854-1918. História, Ciências, Saúde - Manguinhos. Rio de Janeiro, v.21, n.2, abr.-jun. 2014, p.687708

${ }^{30}$ DAILY, Walter: "The Black Cholera comes to the Central Valley of America in 19th Century - 1832 1849 and later." Transactions of The American Clinical and Climatological Association.Vol. 119, San Antonio, 2008, p. 143-53.
} 
que Gilliss descreveu os episódios acima, milhares de pessoas morreram em todo o mundo em decorrência da doença. ${ }^{31}$ Sem cura ou certezas sobre a forma de contaminação, era praxe colocar os navios em quarentena, especialmente os que vinham de locais onde a cólera estava ceifando vidas.

No entanto, tal decisão vinha prejudicando o comércio internacional, fato que desagradava aos comerciantes e prejudicava a economia do país. Todavia, a prática dos agentes de saúde nos dois portos anteriores pelos quais Gilliss passou era a indicada. Sem discorrer sobre os perigos da contaminação, nosso viajante pôde apenas elogiar a "irresponsabilidade" de seu conterrâneo e diminuir a posição firme dos agentes do Equador e da Colômbia que impediram a sua entrada. No entanto, ao verificarmos o número grandioso de mortos na Europa e também nos Estados Unidos, como já indicado, e levando em conta que Gilliss era um homem letrado, sua postura diante das decisões dos agentes e das normas dos países latinoamericanos, é discrepante e egoísta, e denota descaso com os vizinhos do sul.

Gilliss não mencionou a epidemia em seu país. Embora compreenda a situação, sua irritação com os cuidados que atrapalharam seu percurso reproduz a impaciência dos comerciantes do período e mesmo do país, que, ao fechar seus portos, tinham grandes perdas financeiras. Apesar de o procedimento ser comum, Gilliss reflete a ação intransigente e pouco razoável da elite comerciante. Lembremos aqui que essas regiões ainda se debatiam com a formação de um Estado Nacional, e que os recursos para cuidar da saúde pública eram escassos. Desconsiderando todas essas questões, o viajante julgou seus vigilantes sanitários como ignorantes. O "outro" neste relato, permaneceu em seu lugar secundário, aos olhos do norte-americano que, como veremos, irá reproduzir perfeitamente bem o imaginário, os preconceitos e estereótipos da época, com relação aos países e povos sulamericanos.

\footnotetext{
${ }^{31}$ ALMEIDA, Maria Antónia Pires de. op. cit., p. 687-708.
} 
No dia seguinte, Gilliss voltou à cidade de Payta e começou a descrevêla. De vegetação escassa e pouco atraente a seus olhos, logo mira o olhar nas casas feitas de um material que ele considerou ser bambu, madeira como suporte do telhado, que depois era coberto de palha e barro:

As casas são construídas inteiramente de bengalas ou bambus trazidos de Guayaquil, diminuídas e colocadas juntas, com ocasionais reforços de madeira para o suporte do telhado. Muitas são rebocadas com barro e caiadas de branco, embora um número maior permita uma livre circulação do ar. Eles têm telhados altos e pontiagudos, de palha de palmeiras ou folhas de cacau, e beirais com ampla projeção para os transeuntes se abrigarem do grande brilho do sol. Uma coleção de mais miseráveis habitações não se poderia facilmente encontrar em um lugar através do qual tanta riqueza tinha passado; e ainda uma delas, de maneira nenhuma muito extensa, se diz ter custado mais de US\$ 40.000. Os carpinteiros dos Estados Unidos de bom grado forneceriam uma habitação mais ampla e adequada para o clima pela metade do dinheiro. ${ }^{32}$

Assim como havia feito no Panamá, Gilliss destacou o alto custo de serviços que norte-americanos, em sua concepção e sem levar em conta o tipo de material disponível e, o mais importante, adequado para a região, fariam melhor e a um custo menor. Ademais, considero a informação duvidosa, posto que a pobreza desses países era latente, e moradores simples, de casas como ele descreveu, não poderiam dispor, a meu ver, de enorme quantia em dinheiro para a construção de uma casa.

A descrição da população peruana, especialmente dos indígenas, se repete, tal qual os paradigmas da época:

\footnotetext{
${ }^{32}$ GILLISS, op. cit., Vl. I, p. 424. No Original: "The houses are built entirely of split canes or bamboos brought from Guayaquil, and wattled together, with occasional strengthening studding of wood for support of the roof. Many are plastered with mud and whitewashed, though the larger number permit a free circulation of air. They have high-peaked roofs thatched with palm or cocoa leaves', and wide projecting eaves to shelter street passengers from the great glare of the sun. A more miserable collection of dwellings one could not easily find in a place through which so much wealth had passed; and yet one of them, by no means very extensive, is said to have cost more than $\$ 40,000$. The carpenters of the United States would gladly furnish one more extensive and better suited to the climate for half the Money".
} 
A população, estimada em 1.500 almas, se parece de acordo com o seu país e as estruturas que habitam. Eles são geralmente pequenos, os índios de cor escura e desleixados no vestir, como o pior de tais nações são normalmente. Pensamentos de limpeza ou modéstia não encontram espaço em suas mentes; eles estão contentes em se agachar sobre os pisos ou areia sob a sombra dos beirados, e balançar em uma rede de grama parece luxo. No entanto, há rostos interessantes e tranquilos entre as mulheres, com seus cabelos longos, escuros soltos, elencados de características submissas. Os descendentes de espanhóis não são numerosos. ${ }^{33}$

Pequenos, escuros, desleixados, sujos e submissos. Sobre esse olhar que define os indígenas e negros sempre como inferiores em relação aos brancos anglo-saxões, já foi realizada a devida análise no início deste capítulo. Mais uma vez, vemos que a representação de Gilliss sobre esses povos buscou sempre compor a imagem da inferioridade em relação ao homem branco e da degeneração. O que se nota aqui é a representação de um país cujos habitantes são, em sua maioria, esses "seres inferiores".

Sobre o valor dos diferentes tipos de trabalho, a viajante aponta:

Toda a água que consomem é carregada nas costas de mulas de uma distância de 25 milhas. Ela é vendida a dois cents por galão. Carpinteiros de navios recebem um dólar e um quarto por dia; os trabalhadores comuns não menos de sessenta ou setenta cents. Como a disparidade é ocasionada, eu não posso compreender; mas é um tanto anômalo que um carregador de água despenderá de dois dias de seu trabalho, e o de uma mula, por uma remuneração menor do que a que um trabalhador comum obtém sozinho, e a menos que cada arriero (tropeiro) tenha muitos animais sob sua responsabilidade, o seu salário é comparativamente de valor insignificante. $^{34}$

\footnotetext{
${ }^{33}$ GILLISS, op. cit., Vl. I, p. 424. No Original: "The population, estimated at 1,500 souls, appear in keeping with their country and the structures they inhabit. They are generally short, dark-colored Indians, slatternly in dress, as the worst of such nations usually are. Thoughts of cleanliness or modesty do not find restingplaces in their minds; they are contented to crouch about the floors or sand under the shadow of the eaves, and to swing in a grass hammock seems luxury. Yet there are interesting faces among the women, with their long, dark, and flowing hair, and quiet, submissive casts of features. The descendants of Spaniards are not numerous."

${ }^{34}$ GILLISS, op. cit., p. 424. V1. 1. No original: "All the water they consume is brought on the backs of mules from a distance of twenty-five miles. It is sold at two cents per gallon. Ship-carpenters receive a dollar and a
} 
O viajante também encontra dificuldades para compreender o valor dos diferentes tipos de trabalho. A busca por água, sua dura travessia e creio, seu valor essencial a sobrevivência, parece ter mais valor do que outras atividades. Podemos inferir aqui que para Gilliss, o preço do trabalho equivale a quanto o trabalhador despendia de seu tempo e esforço. Há um conflito e mesmo um contrassenso em suas análises, que hora mencionam o auto custo de uma casa, ora não compreende por que um trabalhador não especializado, entregador de águas, ganha menos que um especializado. De todo modo, assim como no Panamá, o oficial informou ao leitor sobre o comércio e as possibilidades de um norte-americano comum ganhar dinheiro levando melhorias para o local.

Se analisarmos a forma negativa como o autor retratou aqueles que saíam em busca do ouro na Califórnia, podemos inferir que ele aponta formas de se fazer dinheiro de outro modo em países pouco desenvolvidos e de forma mais digna, a seu ver. Mais uma vez, é o homem do norte, parte da elite do país, mostrando que a América do Sul necessitava dos norte-americanos para se tornar "civilizado" e trazer o progresso e novas técnicas às pessoas que ali viviam.

Em seu relato sobre Payta, somente as frutas, vegetais e leguminosas foram poupadas de críticas. $\mathrm{O}$ autor se impressionou com vários desses itens e os descreveu como saborosos. As batatas, por exemplo, foram consideradas por ele como superiores àquelas produzidas na Nova Escócia ${ }^{35}$. Lembro aqui, que tal impressão não é prerrogativa apenas de Gilliss, já que na maioria dos relatos de viagem os autores produzem discursos semelhantes. Gilliss dedicou uma página inteira de seu relatório descrevendo principalmente os frutos,

quarter per day; the commonest laborers not less than sixty or seventy cents. How the disparity is occasioned I cannot comprehend; but it is somewhat anomalous that the water-carrier will employ two days of his own time, and that of a mule, for a smaller remuneration than the most common laborer obtains alone, unless each arriero(muleteer) has many animals under his charge, and their hire is of comparatively trifling value".

${ }^{35}$ Cf: GILLISS, op. cit., Vl. 1, p.425. 
feijões e os tipos de batatas do Peru, classificando a quase todos como extremamente saborosos. ${ }^{36}$

A cada porto, Gilliss ofereceu a latitude ao leitor. Também informou sobre acidentes ocorridos durante o percurso, como por exemplo, o encontro do navio com uma perigosa rocha:

8 de outubro. Próximo à entrada norte da baía Casma, latitude 928 '8., eu fiquei assustado ao acordar por volta das $3 \mathrm{~h}$ da manhã por um choque que quase me jogou para fora do leito. Passando rapidamente o convés, o capitão me disse que tinha atingido uma baleia; embora, como já passado para o lado oposto ao olhar para a terra que estava se aproximando, o oficial de quarto sussurrou: "Mais cracas do que gordura nas costas dessa camarada, de qualquer maneira". Se rocha ou baleia, o navio não foi detido em nenhum instante, nem ele vazou [entrou água] mais tarde; mas passou rapidamente a um ponto de ancoragem, escuro como era, acelerou em sua viagem uma ou duas horas mais tarde, quando à luz do dia haveria uma investigação de uma questão tão importante para os navegadores. Subsequentemente, a suposição do chefe se provou correta: uma rocha perigosa foi encontrada aqui. ${ }^{37}$

Essas informações recorrentes apontam para a já informada necessidade de se mapear com precisão os mares. Assim como a descrição da população, da economia local e das possibilidades comerciais, observamos durante o relato a preocupação em informar sobre os locais propícios a acidentes. Essas informações eram de extrema importância, em um período em que ainda não estavam mapeados com a devida precisão os mares já tão transitados pelas nações do mundo.

\footnotetext{
${ }^{36}$ Cf. GILLISS, op. cit., Vol. I, p. 425.

${ }^{37}$ GILLISS, op. cit., V1. I, p. 427. No original: "October 8. Close to the northern entrance of Casma bay, latitude 9 28' 8., I was startled from slumber about 3 A. M. by a shock that nearly threw me out of the berth. Hastening on deck, the captain told me we had struck a whale; though, as I passed to the opposite side to look at the land we were approaching, the officer of the watch whispered, "More barnacles than blubber on that chap's back, anyhow." Whether rock or whale, the ship was not detained an instant, nor did she leak any more afterward; but passed rapidly to an anchorage, pitchy dark as it was, and speeded on her voyage an hour or two later, when daylight would have ted investigation of a matter so important to navigators. Subsequently the surmise of the chief officer proved correct: a dangerous rock was found here."
} 
Em seu relatório, Gilliss afirma ter viajado de Callao a Lima em um "omnibus". Sobre Lima, o cientista viajante escreveu onze páginas. Chegando a Lima, o primeiro local visitado por Gilliss foi a Catedral onde os restos mortais de Pizzaro se encontravam. O viajante claramente colocou em dúvida se, de fato, aquilo seria verdade e salientou a composição bizarra que encontrou, bem como a superstição e ingenuidade da população que acreditava no que lhes era dito sobre este fato, como se pode notar no excerto abaixo:

[...] e em um nicho aberto de um lado, há um esqueleto perfeito, sem tais provas de identidade, mas que o Sacristão nos garantiu que as crônicas da catedral afirmavam serem os restos mortais do conquistador do Peru. Talvez, o digno Sacristão tantas vezes disse: "Aí está Pizarro," que ele realmente pense assim. A carne está totalmente desaparecida a partir do nariz e maçãs do rosto, embora uma porção tenha secado, como nas múmias, permanece em outras partes do corpo. Uma camisa finamente trançada, abotoada perto da garganta. [...] Um sapato permanece no pé; o outro se encontra no corpo. $^{38}$

Em outra descrição sobre a Igreja de Santo Domingo, Gilliss atentou para o dinheiro que era aportado para o convento anexo a esta igreja, assim como ironizou as comemorações católicas regadas com fogos de artifícios:

Outra igreja que atrai muita atenção é Santo Domingo. No momento da nossa visita, foi decorada com flores, e miríades de muitos tons de fitas e velas de cera, preparatórios para uma grande celebração para sair no dia 14 . Ela tem uma frente de 80 pés, profundidade de 300 pés, o mais alto campanário na cidade, e um teto arqueado profusamente ornamentado. [...] O convento a que pertence ocupa uma praça ao todo; e de seus reclusos ainda

\footnotetext{
${ }^{38}$ GILLISS, op. cit., Vl. I, p. 432. No original: [...] "and in an open niche on one side there is a perfect skeleton, without such evidence of identity, but which the Sacristan assured us the chronicles of the cathedral assert to be the remains of the conqueror of Peru. Perhaps, like the traveller already referred to, who talked of his horse, the worthy Sacristan has so often said, "There lies Pizarro," that he really thinks so. The flesh is entirely gone from the nose and cheek-bones, though a portion, dried, as on mummies, remains on other parts of the body. A finely plaited shirt, buttoned closely to the throat [...] One shoe remains on the foot; the other lies on the body."
} 
desfrutam de uma renda anual considerável, embora as fotos de seus claustros negligenciados pareçam sinais de declínio da fortuna. $\mathrm{Na}$ noite de 13 de outubro, a igreja estava muito brilhantemente iluminada, os serviços foram encerrados com uma exibição de fogos de artifício na plazuela a sua frente. Como pirotecnia e religião vêm a ser filiadas, nós hereges [ironia] não estamos autorizados a saber; mas sem dúvida, a igreja é capaz de explicar de forma satisfatória, e as pessoas, evidentemente, aproveitam a primeira tanto quanto a última. ${ }^{39}$

O fato do autor se colocar de forma jocosa, como "herege", diante da cena e do comentário que teceu, indica sua orientação religiosa protestante, já que, por seus julgamentos, católico certamente o oficial não o era.

Em meio a descrições desinteressantes sobre as igrejas e o quanto essas eram numerosas, assim como a quantidade de conventos, Gilliss nos reportou informações interessantes sobre as diferentes funções dos conventos peruanos:

\begin{abstract}
Antes da revolução, havia quarenta e seis conventos de frades e freiras, alguns dos quais foram abandonados ou desmantelados. Há ainda vários além dos nomeados, e quinze ou dezesseis conventos de adolescentes, cada um dos quais tem a sua capela aberta ou oratório. Além disso, há quase sessenta igrejas paroquiais, uma entre os conventos, La Conception, Santa Clara e La Encarnacion são as mais bem dotadas; a Capuchinas, Nazarenas e Trinitária são as mais rigorosas em suas regras conventuais. A primeira não é famosa pela piedade de suas vidas isoladas. O refúgio de San Jose é uma casa em que mulheres que se casaram podem se aposentar quando desejam se livrar dos maus-tratos de maus maridos; e para que, com a permissão do arcebispo, maridos possam enviar
\end{abstract}

\footnotetext{
${ }^{39}$ GILLISS, op. cit., Vl. I, p. 432. No original: "Another church that attracts much attention is Santo Domingo. At the time of our visit it was decorated with flowers, and myriads of many-hued ribbons and wax candles, preparatory to a great celebration to come off on the 14th. It has a front of $80 \mathrm{feet}$, depth $300 \mathrm{feet}$, the highest steeple in the city, and a profusely ornamented arched ceiling. There is an altar dedicated to Santa Rosa, whose relics are preserved here near the chapel pertaining to the titular saint, and one to Our Lady of the Rosary, besides many chapels ornamented with figures illustrating passages of Scripture. The convent to which it belongs! occupies a whole square; and its inmates still enjoy a handsome yearly income, though the neglected pictures of its cloisters seem tokens of declining fortune. On the evening of October 13 the church was very brilliantly lighted, the services closing with a display of fireworks on the plazuela before it. How pyrotechnics and religion come to be affiliated we heretics are not permitted to know; but doubtlessly the church is able to explain satisfactorily, and the people evidently enjoy the former quite as much as the latter."
} 
temporariamente suas esposas, se eles acharem que um pouco de reclusão e meditação tranquila provavelmente melhorem os seus hábitos. Há também uma casa de refúgio para mulheres indigentes... ${ }^{40}$

Essa atenção dada pela Igreja ao sexo feminino certamente chamou a atenção do viajante, que se demorou em explicar as diferentes instituições católicas que abrigavam mulheres com distintas situações, embora todas, aparentemente, necessitadas de ajuda.

Sobre os hospitais, relatou, mas não elogiou, embora a quantidade destes merecesse maior apreço:

Os principais hospitais são San Andrés para os homens, e de Santa Ana para as mulheres. O antigo foi fundado em 1552, e foi subsequentemente ampliado até que ele pudesse acomodar 400 pacientes. Uma parte do edifício é apropriado para os pobres, que recebem assistência gratuita; e outro é separado para pessoas insanas. É muito habitual para o público visitar o hospital no dia de St. Andrew, momento em que os loucos são objetos de mais curiosidade e observação. Santa Ana foi fundado há três anos. Ele tem agora treze alas, contendo cerca de 300 camas. San Bartolomeu, um hospital militar, tem onze alas e 220 camas. Um hospital originalmente destinado a pacientes hansenianos foi fundado em 1669. Agora, as pessoas que são enviadas para lá são as que podem ser atingidas com doenças cutâneas de qualquer espécie, mas, sobretudo, as de caráter contagioso. O hospital de enjeitados, instituído no início do século XVII, tem apenas cerca de 100 crianças sob os seus cuidados. $^{41}$

\footnotetext{
${ }^{40}$ GILLISS, op. cit., Vl. I, p. 433. No original: "Prior to the revolution there were forty-six convents of monks and nuns, some of which have been abandoned or broken up. There are still several besides those named, and fifteen or sixteen nunneries, each of which has its open chapel or oratory. Moreover, there are nearly sixty parish churches 1 Amongst the nunneries, La Conception, Santa Clara, and La Encarnacion are the best endowed; the Capuchinas, Nazarenas, and Trinitarian are the most rigorous in their conventual rules. The former have not been famed for the piety of their secluded lives. The liefugio de San Jose is a house to which married women may retire who desire to with draw from the ill-treatment of bad husbands; and to which by permission of the archbishop husbands may temporarily send their wives, if they think a little seclusion and quiet meditation likely to improve their manners. There is also a house of refuge for indigent females..."

${ }^{41}$ GILLISS, op. cit., V1. I, p. 433. No original: "The principal hospitals are San Andres for males, and Santa Ana for women. The former was founded in 1552, and has subsequently been added to until it can accommodate 400 patients. One portion of the building is appropriated to the poor, who receive gratuitous assistance ; and another is set apart for insane persons. It is quite customary for the public to visit the hospital on St. Andrew's day, at which time the lunatics are objects of most curiosity and remark. Santa Ana
} 
Sobre a construção ocupada pelo presidente do Peru, Gilliss

afirmou:

[...] é um edifício de aparência média, o que se poderia supor a propriedade de mascates, em vez de a habitação do magistradochefe de uma nação. ${ }^{42}$

Podemos inferir aqui que Gilliss procurou, de forma indireta, mostrar que a casa do presidente, símbolo do governo republicano, não estaria à altura de uma residência presidencial. Ao comparar com a moradia de mascates, o oficial menosprezou também de forma indireta o tipo de instituição republicana ali instaurada. Ele criticou, assim, a ostentação da Igreja Católica e a simplicidade da residência do presidente.

Sobre as universidades, ressaltou sua atual decadência e culpou tal estado pelo fato de serem administradas pela Igreja. No que tange a escola de medicina, o autor faz críticas quanto à formação dos estudantes:

Uma faculdade de medicina foi fundada em 1810, com sete professores. Em 1834, Dr. Ruschenberger a pensou em um estado decadente; apesar de ser ligada a extensos hospitais, e não haver preconceitos existentes contra dissecações, ela poderia ter se tornado, em outras mãos, uma escola florescente. Sete anos mais tarde, o Dr. Von Tschudi afirma que ela [a faculdade] bem merecia o nome Colejio de la Medecina de la Independencia, que tinha sido atribuído em 1826; pois que, certamente, a medicina era ensinada lá com uma independência singular de todas as regras e sistemas. Ele acreditava que os professores nunca tinham recebido qualquer tipo de ensino regular, e o escasso conhecimento era transmitido para os alunos de uma forma muito imperfeita. A escola de obstetrícia para o sexo feminino tem 18 alunas [...]. Um hospital-leito está

was founded three years previously. It has now thirteen wards, containing about 300 beds. San Bartolome, a military hospital, has eleven wards and 220 beds. A hospital originally intended for leprous patients was founded in 1669. Now, persons are sent there who may be afflicted with cutaneous maladies of any kind, but more especially with those of a contagious character. The foundling hospital, instituted at the commencement of the seventeenth century, has only about 100 children under its charge."

${ }^{42}$ GILLISS, op. cit., V1. I, p. 433. No original: “...is a mean-looking building, which one would suppose the property of peddlers rather than the dwelling of a nation's chief magistrate.” 
conectado com este, onde os pobres são assistidos gratuitamente, e, posteriormente, são oferecidas assistências durante dez dias. O número de nascimentos na mesma instituição no ano que terminou em 30 de setembro de 1851 foi de 245; morte de parturição, 1; abortos, 33. Os gêmeos nasceram em fevereiro, março e maio. ${ }^{43}$

Note-se que os dados recolhidos são referentes ao ano de 1851, dois anos após a passagem de Gilliss pelo local. Isso nos lembra, mais uma vez, que o relato é construído de diversas maneiras: a consulta de diários, das memórias e de documentos pesquisados após a viagem, por exemplo. Assim, muito do que consta no relatório de Gilliss não corresponde ao que o autor pesquisou no período em que esteve na região e sim, a dados recolhidos muitas vezes após a viagem.

Sobre lazer e as artes, o autor retratou também uma imagem de atraso e mostrou que os habitantes de Lima tinham como principal fonte de lazer festas ou atividades religiosas. Apresentações artísticas, como a ópera, aconteciam de forma escassa e sempre eram apresentações de artistas de "segunda classe". Veremos que Gilliss fechou o tema mostrando que ainda assim, era difícil se deixar entreter nessas ocasiões em meio a tantos mosquitos, mesmo no interior do teatro:

A partir do número de letreiros sobre a praça, alguém poderia sugerir que ali se encontram uma sucessão de divertimentos públicos dos quais um estrangeiro poderia participar. Isso, porém, não é a realidade; uma inspeção mais próxima dos avisos prova que a maioria deles se refere à religião, em vez de assuntos seculares. $\mathrm{O}$ teatro é aberto apenas uma parte do ano [...]. Sua orquestra é

\footnotetext{
${ }^{43}$ GILLISS, op. cit., V1. I, p. 435. No Original: "A medical college was founded in 1810, with seven professors. In 1834 Dr. Ruschenberger thought it in a languishing state; though from being attached to extensive hospitals, and no prejudices existing against dissections, it might in other hands have become a flourishing school. Seven years later, Dr. Von Tschudi says it well deserved the name Colejio de la Medecina de la Independencia, which had been conferred on it in 1826 ; for, certainly, medicine was taught there with a singular independence of all rules and systems. He thought the professors had never received any regular instruction, and their scanty share of knowledge was communicated to the students in a very imperfect manner. A school of obstetrics for females has 18 pupils; [...] A lying-in hospital is connected with this, where the poor are as sisted gratuitously, and subsequently afforded succor during ten days. The number of births at the latter institution in the year ending September 30, 1851, was 245; death from parturition, 1; abortions, 33. Twins were born in February, March, and May."
} 
geralmente boa; e quando alguns dos melhores cantores de ópera de segunda categoria fazem visitas às capitais ao longo da costa oeste, como fazem ocasionalmente, toda a beleza e moda [alta sociedade] de Lima se aglomeram para ouvi-los. Geralmente, no entanto, os atores de comédias e tragédias atraem plateias pequenas; e para ficarem até o fim de suas apresentações, sob as perseguições dos insetos que pululam como em casas fechadas todo o tempo, o estrangeiro, pelo menos, precisa da pele de um rinoceronte. ${ }^{44}$

Sobre o mercado, o autor deu destaque aos tipos indígenas e aos miscigenados, representando-os, como de costume, como seres que já em sua aparência, denunciavam sua inferioridade:

Crioulos espanhóis frequentam o lugar sem capacidade; e embora os negros e suas misturas formem uma numerosa parcela dos habitantes ao redor do mercado, a massa é, inequivocamente "Children of the Sun". Eles são uma raça corpulenta e baixa, com muitas das características fisionômicas proeminentes das tribos norte-americanas; e os ídolos pertencentes aos seus antepassados, que ainda são ocasionalmente desenterrados, provam que o lapso de séculos forjou pequena mudança no elenco nacional de suas características. ${ }^{45}$

Mas nem tudo foram críticas. Como já dito, as verduras, legumes e frutas foram alvo de elogios, assim como algumas espécies de flores, as quais Gilliss chegou a afirmar que algumas eram de uma beleza que não encontrou nos Estados Unidos:

\footnotetext{
${ }^{44}$ GILLISS, op. cit., Vl. I, p. 435. No original: "From the number of placards about the plaza one might infer that there is a succession of public amusements in which the stranger at Lima may participate. Such, however, is not the fact; closer inspection of the notices proving that the majority of them refer to religious rather than to secular affairs. The theatre is open only a part of the year; [...] Its orchestra is usually good; and when some of the best second-rate opera-singers make visits to the capitals along the west coast, as they do occasionally, all the beauty and fashion of Lima crowd to hear them. Generally, however, the actors of comedies and tragedies attract small audiences; and to sit out their performances, under the persecutions of the insects that swarm about all long-closed houses, the foreigner at least needs the hide of a rhinoceros." ${ }^{45}$ GILLISS, op. cit., Vl. I, p. 437. No original: "Creole Spaniards frequent the place in no capacity; and though negroes and their admixtures form a numerous portion of the denizens about the market, the mass are unmistakably "Children of the Sun." They are a short, stout-built race, with many of the prominent physiognomic characteristics of the North American tribes; and the idols belonging to their ancestors, that are still occasionally disinterred, prove that the lapse of centuries has wrought little change in the national cast of features."
} 
Rosas, dálias únicas, dois ou três variedades de escabiosas, cravinas, esporinha-gigante, manjerona, e vários tipos de malmequeres [cravo/calêndula], estão entre os mais numerosos; mas também há plantas anuais de grande beleza que eu nunca vi nos Estados Unidos. Onde quer que haja o mínimo de umidade pelas estradas, [flores] cinco-chagas amarelas e vermelhas e [folhas de] falso-acanto crescem profusamente; e próximo de fendas nas colinas rochosas na parte de trás da cidade eu encontrei uma oxalis [falso trevo] muito bonita, uma planta-gelo, um cacto longo e afunilado em flor, e várias outras espécies desconhecidas para $\operatorname{mim}^{46}$

Relatos que dão ênfase a natureza exótica local dos países sulamericanos são comuns no período. Não podemos deixar de mencionar a influência do geógrafo e naturalista alemão Alexander von Humboldt, importante viajante que realizou expedições na América do Sul com o objetivo de retratar e estudar o homem e a natureza locais, em seus mais variados aspectos, produzindo um vastíssimo trabalho nos quais estabeleceu padrões científicos de observações da natureza e das populações, combinando, de acordo com Mary Louise Pratt, "a especificidade da ciência com a estética do sublime" e tornando-se referência para os viajantes posteriores, como afirma $\operatorname{Pratt}^{47}$.

Apesar de Humboldt e de sua influência sobre viajantes em geral e na escrita dos relatos de viagem científicos, notamos que o homem não ajudava diante da paisagem encontrada. Como o leitor já observou, imperou no relatório as representações negativas, com relação aos mais diferentes aspectos da sociedade. O excerto abaixo mostra a impressão do autor sobre a forma pouco higiênica com que se dava o corte de gado:

\footnotetext{
${ }^{46}$ GILLISS, op. cit., Vl. I, p. 437. No Original: "Roses, single dahlias, two or three varieties of scabius, pinks, larkspurs, sweet marjoram, and several kinds of mari- golds, are among the most numerous; but there are also annuals of great beauty that I never saw in the United States. Wherever there is the least moisture by the roadsides, yellow and scarlet nasturtiums and Scotch thistles grow profusely; and about crevices on the rocky hills at the back of the city I found a very pretty oxalis, an ice-plant, a long and tapering cactus in flower, and several other species unknown to me."

${ }^{47}$ Cf. PRATT, Mary Louise. Os olhos do Império, op. Cit.,p.213.
} 
Eram animais devidamente abatidos, e as carnes adequadamente cobertas e exibidas, elas sem dúvida pareciam tão boas quanto eram saborosas, depois de serem preparadas. Mas elas são abominavelmente retalhadas e mutiladas, e então colocadas em bancos sujos em protuberâncias horríveis, e expostas por mulheres indígenas ou negras desleixadas e imundas. Portanto, mesmo depois de alguém estar devidamente seguro de que não será comido vivo por cães e pulgas, se ele tem órgãos digestivos delicados, uma caminhada através do mercado de carne antes do café é pouco recomendável. Carneiro e carne de vaca são mais abundantes; carne de porco é rara; vitela, cordeiro e suínos jovens são proibidos. ${ }^{48}$

O oficial não apenas relatou a forma pouco higiênica e convidativa aos olhos sobre como as carnes eram cortadas, mas deixou claro que o grande problema era a manipulação delas feitas por mãos indígenas ou negras que ele classificou como sendo de pessoas imundas. A questão racial pode não ser analisada pelo autor com a devida "profundidade", mas ao longo do relato, vai se tornando cada vez mais clara a sua percepção sobre as demais "raças" que povoavam a América do Sul como inferiores à raça branca.

No que se refere às questões geopolíticas, o autor procurou oferecer as informações esperadas em um relatório oficial da Marinha. Assim, compilou dados sobre a cidade e sua população, embora em alguns aspectos, como a questão das "raças", afirmou que nem as autoridades conseguiam apurar as mesmas e suas miscigenações com clareza:

Entre tais assuntos pode ser mencionada a população, nas suas diversas classes e seus recursos industriais, dados essenciais para uma estimativa adequada do progresso de uma cidade. Inquéritos, respeitando o número agregado dentro dos limites da cidade em outubro de 1849, obtiveram respostas bastante uniformes de 60.000

\footnotetext{
${ }^{48}$ GILLISS, op. cit., V1. I, p. 437. No original: "Were animals properly slaughtered, and the meats appropriately dressed and exhibited, they would doubtless look as well as they taste when subsequently cooked. But they are abominably hacked and mutilated, then placed on dirty benches in ugly lumps, and disposed of by slouchy and unclean Indian or negro women. Therefore, even after one duly obtains insurance against being eaten alive by dogs and fleas, if he have delicate digestive organs a walk through the meat market before breakfast is scarcely commendable. Mutton and beef are most abundant; pork is rare; veal, lamb, and young pigs are prohibited."
} 
almas; mas sobre as proporções relativas dos nativos (índios), brancos e negros, crioulos e as várias castas decorrentes das três raças, só havia uma resposta à minha pergunta: quien sabe? E quem na verdade, sabe? Índios de sangue não misturados são numerosos, e são inconfundíveis com o seu quadro quase universal, pequenos e fortes, altas maçãs do rosto e cabelos pretos e lisos. A linhagem espanhola também é normalmente bem marcada; mas casamento com descendentes de seus vizinhos Normandos e cruzamentos com sangue índio tornaram sua classe menos distintiva, tanto em cor quanto em fisionomia. Os estrangeiros podem ser facilmente detectados por seu sotaque; e embora a cor da pele possa colocá-los entre os filhos de branco originais ou da cor do cobre dos pais, os negros são traídos por seus cabelos e lábios. Entretanto, estimar quantos existe de cada [grupo] parecia impossível a qualquer estimativa, com provável aproximação à verdade. Dr. Von Tschudi enumera nada menos do que vinte e dois tipos de mestiços, e diz que há muitos outros não distinguidos por nomes específicos, porque eles não diferem materialmente na cor que eles têm. ${ }^{49}$

Sobre o clima, há em sua descrição a associação deste com as doenças consideradas típicas dos trópicos. A explicação dada pelo autor sobre o clima e a associação deste a profusão de doenças e do alto índice de mortalidade dá ao Peru um status de permanente ciclo de doenças e morte. A ideia de clima como responsável pelo progresso humano e do país em si é bastante clara no excerto que veremos abaixo. Sobre a questão comercial, Gilliss fez um alerta aos interessados em investir em Lima:

Em alguns anos, fábricas de algodão, lã, e vidro foram estabelecidas nos subúrbios da cidade; para proteger cada uma, o

\footnotetext{
${ }^{49}$ GILLISS, op. cit., Vl I p. 437. No original: "Among such subjects may be mentioned population, in its various classes and their industrial resources, data essential to a proper estimate of a city's progress. Inquiries respecting the aggregate number within the city limits in October, 1849, obtained pretty uniform replies 60,000 souls; but as to the relative proportions of natives (Indians), Creole whites, and negroes, and the several castes arising from the three races, there was but one response to my query quien sabe? and who indeed does know? Indians of unmixed blood are numerous, and are unmistakable with their nearly universal short and stout frames, high cheek-bones, and straight black hair. Spanish lineage, also, is ordinarily well marked; but intermarriage with descendants of their Norman neighbors, and crossings with Indian blood, have rendered their class less distinctive, both in color and physiognomy. Foreigners may be readily detected by their accent; and even though the color of the skin might place them among offspring of original white or copper-colored parents, negroes are betrayed by their hair and lips. Yet how many there are of each it seemed impossible to make any estimate of, with probable approximation to truth. Dr. Von Tschudi enumerates no less than twenty-two half-castes, and says there are many others not distinguished by particular names, because they do not differ materially in color from those he has."
} 
governo impôs enormes direitos sobre artigos semelhantes de produção estrangeira. Mas todos tinham definhado até a data das minhas visitas, devido às importações de mercadores estrangeiros, antes da lei entrar em vigor, de uma quantidade de bens suficientes para durar seis ou sete anos. Assim, eles ainda eram capazes de vender a preços mais baixos do que o fabricante nacional; e acredita-se que todas as empresas faliriam antes que todas as empresas estrangeiras esgotassem seus estoques. [...]. Utensílios e ornamentos de ouro e prata, ambos sólidos e delicadamente ornados, fornecem emprego a um grande número de artesãos; mas há poucas fábricas domésticas de qualquer tipo para atrair riqueza a partir do estrangeiro. ${ }^{50}$

E assim, de forma extremamente paradoxal, após narrar as mazelas de um país pobre e miscigenado, Gilliss se despediu da cidade como se estivesse deixando para trás o paraíso na terra. E curiosamente neste momento ele se dispõe a mencionar a beleza do povo, da paisagem e da história anterior a invasão espanhola:

Eu lamentei deixar a pitoresca antiga "Cidade dos Reis". Há uma magia em seu heroico entorno; começando com a história quase fabulosa do seu passado, ainda ligada ao presente fantástico por pequenos incontáveis romances que alienam a vida dos prosaicos que a tornam lar, como em um melodrama tedioso. Curta e ocupada no negócio de passeios turísticos, como a visita foi, suas influências tinham me feito pensar que isso estava mais perto do paraíso terrestre do que qualquer outra parte do nosso belo mundo; e eu pude deixar de lamentar que o destino não tenha colocado meu quinhão em tão agradável local.

Seu clima, frutas e flores; seus solenes templos antigos, com seus sinos musicais; a pompa eterna das ruas, onde trajes competem em variedades com a cor da pele, desde as neves do Cáucaso para o ébano da África; as maravilhas da sua história; suas câmaras empilhadas com ouro para o resgate real, e ruas pavimentadas com

\footnotetext{
${ }^{50}$ GILLISS, op. cit., Vl. I, p. 438-9. No original: "Within a few years manufactories of cotton, wool, and glass have been established in the suburbs of the city; to protect which, government imposed enormous duties on similar articles of foreign production. But they had all languished to the date of my visits, owing to importation by the foreign merchants, before the law went into effect, of a quantity of goods sufficient to last six or seven years. Thus they were still able to undersell the domestic manufacturer; and it was believed that the whole of the companies would fail prior to the time when the foreign stocks would be exhausted. [...]. Utensils and ornaments of silver and gold, both solid and fillagree, furnish employment to quite a number of artisans ; but there are few domestic manufactures of any kind to attract wealth from abroad."
} 
prata para homenagear em honra vice-reinal; a calma, resignada magnanimidade de seu último Inca, cujos seguidores simples, 'religiosos em sua ignorância, adorando o sol que olha para seus adoradores, mas não sabe mais nada deles!,' a imolação de hecatombes pelo comando desse tribunal secreto e irresponsável, o mistério de tal tribunal, ou de seus implementos para despedaçar os cordões da vida, um por um, ninguém que escapou ousa falar disso; quanto mais do que a tirania e as extorsões de uma longa sucessão de vice-reis; as contestações quando o oprimido resolveu se livrar de seus tiranos, ou entregou vidas que não mais mereciam preservar; e o epitalâmio [poema escrito para as noivas na Grécia Antiga] final, quando uma nova estrela foi adicionada à galáxia das repúblicas; tudo isso estendeu os braços convidativos ao viajante, e insensível é aquele que resiste a tais solicitações voluntariamente. Porque, o próprio mendigo aqui se senta no sol sorrindo do excesso de contentamento; e embora se possam ver as mulheres curvadas sob fardos em suas cabeças, coroas de flores adornam os cabelos; e se a face for uma abertura para o coração, uma grinalda mais brilhante a circunda. Ascendendo à escada social, existem pessoas graciosas e carruagens, com as majestosas damas que se reúnem na atmosfera agradável da sua alameda; música cativante em sua linguagem para aperfeiçoar encantos e conquista os quais seus olhos raramente deixam imperfeitos; e se senta sob os galhos de seus salgueiros pendentes ouvindo as canções de aves a partir de suas verdes moradas, e os murmúrios do Bimac impetuoso corroendo os obstáculos no seu caminho, esquecido das horas que o Tempo está inscrevendo em seu volume de ouro. ${ }^{51}$

\footnotetext{
${ }^{51}$ GILLIS, op. cit., V1 I, p.439. No original: "I was sorry to leave that quaint old " City of the Kings." There is a witchery in one's surroundings hero; commencing with the almost fabulous history of the past, yet linked to the fanciful present by numberless little romances that divest life of the prosiness which renders it at home but a tedious melo-drama. Short, and occupied in the business of sightseeing, as the visit was, their influences had made me think this came nearer to terrestrial paradise than any other portion of our beautiful world; and I could but regret that fate had not cast my lot in so pleasant a spot. Its climate, fruits, and flowers ; its solemn old temples with their musical bells; the eternal pageantry of streets, where costumes vie in varieties with the color of the skin, from the snows of Caucasus to the ebony of Africa; the wonders of its history ; its chambers piled with gold for royal ransom, and streets paved with silver to honor vice-regal advent; the calm, uncomplaining magnanimity of its last Inca, whose simple followers

"Religious in their ignorance, adored The sun that looks upon his worshippers, But knows of them no more !"

The immolation of hecatombs by command of that secret and irresponsible tribunal, the mysteries of whose court, or its implements for rending life-strings one by one, none who escaped dare tell of; the more than royal tyranny and extortions of a long succession of vice-kings; the contests when the oppressed had resolved to shake off their task-masters, or yield up lives no longer worth preserving ; and the final epithalamium when a new star was added to the galaxy of republics; all these extend their inviting arms to the traveller, and insensible is he who can voluntarily resist such solicitations. Why, the very beggar here sits in the sun smiling from excess of contentment; and though one may see women bending under burdens borne on their heads, wreaths of flowers adorn their hair; and if the face be an index to the heart, a brighter chaplet circles it. Ascending the social ladder, there are graces of person and carriage, with all the queenly dames one
} 
O excerto que acabamos de ler, embora longo, não deve ser cortado. Escrito em forma de poema, é contraditório com as impressões de viagem de Gilliss sobre o Peru. Vimos suas descrições sobre as pessoas, as paisagens, o lazer e a economia que ia mal por conta de restrições governamentais. Ao fim do capítulo, nos deparamos, no entanto, com um poema, que enaltece os Incas, a natureza, as mulheres e que chega ao ponto de insinuar que o autor desejaria ali viver!

Embora seja considerado nessa análise o fato de que um relato de viagem abriga uma multiplicidade de visões e contradições e que por isso, não se pode esperar uma postura uniforme do viajante, Gilliss, muitas vezes, ultrapassou o limite do que se pode esperar nesse sentido. No caso do Peru, não há nada, de fato, que explique, ao longo de seu relato, uma finalização poética e de exaltação de um lugar que ele ao longo de toda a sua narrativa, criticou. Por essa razão, creio que sua opção em amenizar suas críticas com um poema elogioso, certamente foi política. Em tempos de estreitamento das relações políticas e comerciais com a região, não era prudente escritas tão pejorativas, embora certamente sua finalização não tenha amenizado a imagem que ele construiu sobre o lugar.

A escolha do trajeto de Gilliss até o Chile indica que os interesses políticos e comerciais eram grandes o suficiente para sobrepor-se as epidemias como a cólera, que matava milhares na região pela qual o oficial precisou atravessar. Notemos que nenhuma palavra sobre o risco corrido por ele foi dita no relatório. Afinal, era um oficial cumprindo o seu dever que, gostasse ele ou não, ia além do científico.

meets in the balmy atmosphere of its Alameda; a win-some music in their language, to perfect charms and conquest which their eyes rarely leave imperfect; and one sits beneath the branches of its pendulous willows listening to the songs of birds in their green homes, and the murmurs of the impetuous Bimac fretting at the obstacles in its way, forgetful of the hours that Time is inscribing in his golden volume." 


\section{Capítulo IV - Imagens do Chile por James Melville Gilliss}

\section{1 - Breve relato sobre a construção do Observatório astronômico}

Ao aportar no Chile em vinte e cinco de outubro de 1849, após negociações com o governo local, Gilliss imediatamente deu inicio à busca do local mais adequado para instalar o observatório, e escolheu Santa Lucia, situada em uma colina rochosa, na parte leste de Santiago, como local apropriado para a missão. O governo chileno colaborou com a expedição, providenciando acomodações para a equipe e homens para trabalhar na fundação estrutural da construção do observatório. O edifício em si seria trazido pré-fabricado dos Estados Unidos por navio em rota pelo Cabo Horn.

No início de dezembro, o observatório estava erguido, e Gilliss iniciou imediatamente a primeira série de observações de Marte com o telescópio equatorial por quarenta e seis noites — de 10 de dezembro de 1849 ao fim de janeiro de 1850. Ainda em dezembro, chegou de Berlim o círculo meridiano e este logo foi empregado com precisão para fixar a posição de cada estrela a ser comparada. ${ }^{1}$

A segunda série de observações se iniciou em outubro de 1850 e terminou em fevereiro de 1851, agora, observando Vênus. Uma segunda série de observações de Marte ocupou noventa e três noites, de dezembro a março de 1852. A série final de Vênus ocorreu entre o final de maio até o meio de setembro de 1852. Todas essas séries buscavam a medida da paralaxe solar. Quando não estava ocupado com essas observações, Gilliss e sua equipe trabalhavam no mapeamento das estrelas do sul. Se considerarmos que os expedicionários passavam de seis a sete horas por noite ocupados com tais

\footnotetext{
${ }^{1}$ Instrumento utilizado para determinar as coordenadas na abóbada celeste. Trata-se de um equipamento que contém uma lente montada no plano meridiano do observatório astronômico e é livre para realizar movimentos circulares. Pode-se medir diretamente a altura de um corpo celeste quando este atravessa a linha do meridiano.
} 
observações, notaremos que o trabalho foi intenso e provavelmente bastante fatigante.

Gilliss também deveria realizar e registrar observações magnéticas em conjunto com os observatórios dos Estados Unidos, com o objetivo de descobrir a relação existente entre as variações magnéticas nos dois hemisférios. Vale mencionar aqui, que Gerling também colaborou, realizando suas observações em Marburg, na Alemanha. Ao contrário das observações da paralaxe e do mapeamento das estrelas, as demais não dependiam de um céu claro e estes programas foram realizados com total sucesso. A última série de observações de Vênus ocorreu em outubro de 1852 e, ao fim desta, o trabalho da expedição estava terminado.

Gilliss coordenou os trabalhos dos dois oficiais norte-americanos e de seu assistente pessoal, além de outros três voluntários chilenos (um professor de matemática da Universidade do Chile, fundada em 1843, e dois de seus melhores alunos). Contudo, aproveitando a rara oportunidade, sempre que não era possível realizar suas observações, Gilliss percorreu algumas regiões do Chile, buscando apreender distintos conhecimentos sobre o país e sobre sua população. 


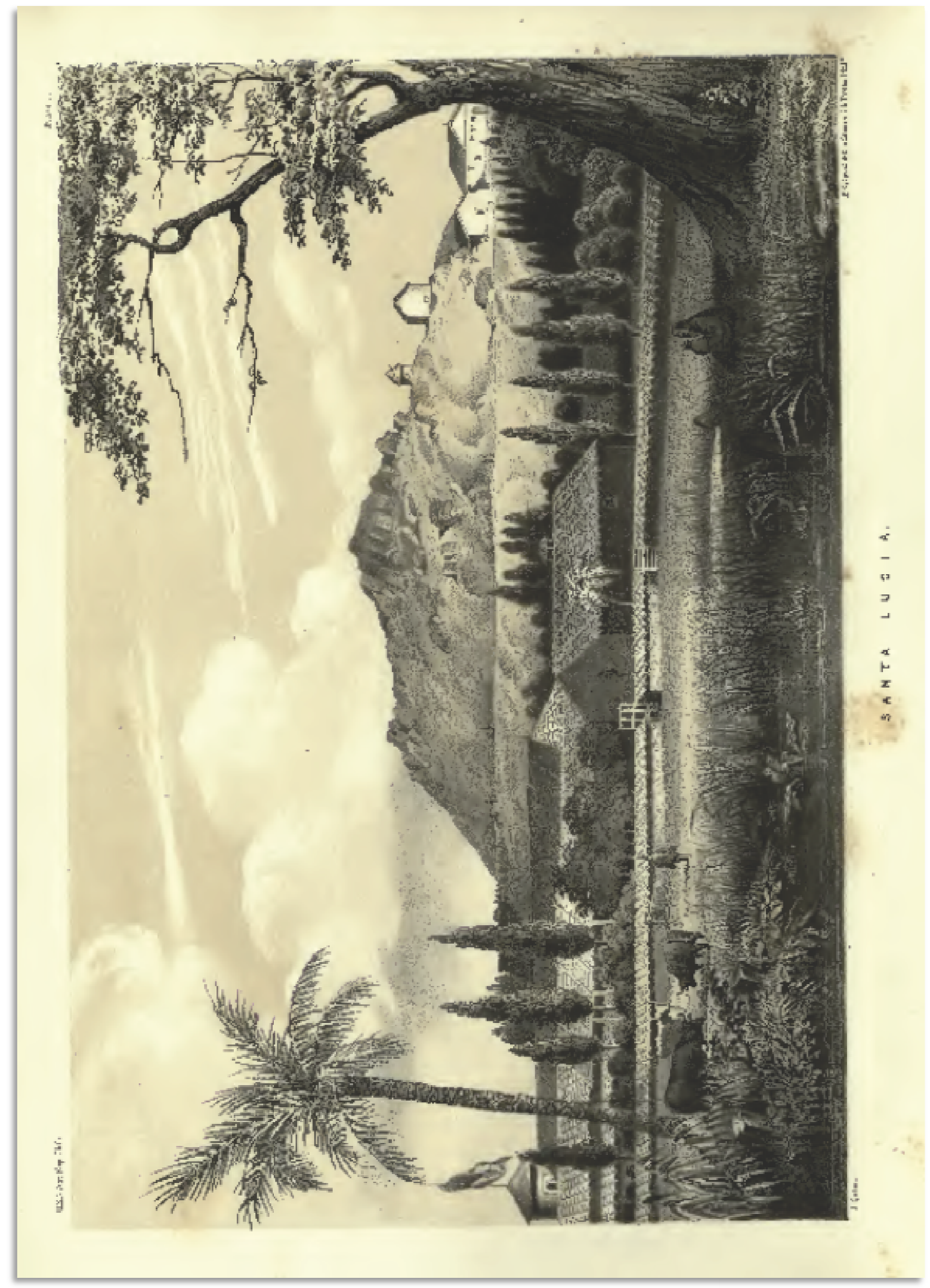

Imagem do Observatório astronômico erguido no Chile. ${ }^{2}$

\footnotetext{
${ }^{2}$ Cf: GILLISS, op. cit., Vol. I, p. I.
} 


\section{2 - As redes de contato}

Ao analisar as redes de contatos traçadas por Gilliss e pelos chilenos, veremos que, assim como Gilliss procurou Gerling e com ele manteve estreito contato, cientistas chilenos e o seu governo fizeram o mesmo movimento em busca de especialistas e letrados, muito antes da chegada de Gilliss ao país. Já na década de 1830, o governo chileno se empenhou em trazer cientistas europeus das mais variadas áreas, e também lá se exilaram alguns intelectuais importantes da América do Sul, como o venezuelano Andrés Bello e o argentino Domingo Faustino Sarmiento, que contribuíram com a universidade e instituições governamentais no âmbito do desenvolvimento educacional e científico da nação. Quanto aos europeus, destacam-se os de origem francesa e germânica, embora haja também poloneses e ingleses compondo o quadro de mestres que viriam ao país contribuir para a sua formação e progresso nas mais diversas áreas. Portanto, os Estados Unidos eram apenas mais uma nação a colaborar - ainda assim de forma indireta - com um projeto preexistente de desenvolvimento científico do país, levado a cabo por seus próprios dirigentes políticos, cientistas e letrados.

Naquela época, assim como nesta, não há meios de se fazer ciência sem cooperação entre os cientistas, como já discutido no início dessa pesquisa. Assim, veremos que uma rede de contatos transnacional se formou, engendrando laços movidos por interesses comuns, resultando em posteriores vínculos profissionais que nasceram a partir das redes de contato científicas.

Gilliss, como vimos, foi ao Chile devido a uma interessante proposta de observação astronômica que chegou até ele através do já citado astrônomo germânico - Christian Gerling. Em 1850, menos de um ano depois da chegada de Gilliss ao país, chegou o matemático Karl Wilhelm Moesta, de Zierenberg, Alemanha. Seu título de doutor foi recebido na Universidade de Marburg, onde trabalhou com Gerling, que, por sua vez, o recomendou como diretor do Observatório Nacional do Chile, quando a expedição norte- 
americana concluiu suas operações no país e vendeu o observatório e seus equipamentos ao governo chileno. Cabe aqui informar que os assistentes de Moesta no observatório foram justamente os dois jovens estudantes chilenos que "estagiaram" com Gilliss e sua equipe.

Ao analisarmos esse quadro, vemos uma trama de contatos internacionais se interligando a partir de cientistas de países que buscavam se consolidar no campo da Astronomia. Os Estados Unidos, junto aos demais, buscaram esse espaço a partir da união com astrônomos de lugares distintos, fato que viabilizou o projeto da expedição astronômica de Gilliss.

Os esforços em encontrar a medida exata da paralaxe solar permaneceram após o término da expedição astronômica da U.S. Navy. Moesta coordenou sua equipe no Chile, que manteve o programa de observações de Gerling por alguns anos. Além disso, o Chile começou a participar do programa mundial de expedições astronômicas. Em 1853, Moesta foi ao Peru observar um eclipse solar. Gilliss escreveu à Andrés Bello, então reitor da Universidade do Chile, pedindo sua intervenção em favor da autorização da expedição chilena, comunicando que havia uma solicitação internacional vinda de astrônomos de Bonn, parte da atual Alemanha, que pedia a colaboração de todos os capitães de barcos que se encontravam no Pacífico para que reportassem qualquer observação feita do eclipse. A carta oferece indícios sobre como a cooperação internacional científica foi utilizada como recurso argumentativo. Não sabemos se a correspondência de Gilliss foi decisiva ou não, mas o fato é que a expedição não só foi autorizada, como permitiu que um auxiliar, um norte-americano - Mr. Clark - participasse no empreendimento. ${ }^{3}$

\footnotetext{
${ }^{3} \mathrm{O}$ Documento não fornece os dados completos dos acompanhantes, por isso, até o momento, não foi possível encontrar maiores informações sobre o norte-americano que acompanhou a expedição. Em um dos relatórios encontrados sobre a expedição, Moesta se refere a Clark, apenas pelo sobrenome, referindo-se a ele como um "inteligente viajante da América do Norte". Cf: Montly notices of the Royal Society. Vol. XIV, 1853-4. London: George Barclay, 1854. p.226.
} 
Em 1862, Moesta iniciou uma sequência de observações de Marte. Desta vez, o pedido veio de um observatório russo, em Pulkovo, que solicitou cooperação internacional para que, mais uma vez, tentassem alcançar a exata medida da paralaxe solar. Gilliss apoiou o projeto e escreveu à Moesta, solicitando a mesma cooperação.

As redes de contato não envolveram apenas o intercâmbio e a troca de informações entre cientistas. Ao explorar o país, Gilliss também manteve seu olhar atento às possibilidades de investimento pelos norte-americanos como já dito. Em 1851, o oficial visitou a região de Coquimbo acompanhado de William Wheelwright, que, como já vimos, era um empreendedor norteamericano ligado a construções de linhas férreas e marítimas. Este, além das estradas de ferro dentro do Chile, pretendia construir outra, ligando o país à Argentina, e foi companhia constante de Gilliss durante sua estadia no Chile. ${ }^{4}$

Assim, o relato nos mostra como diversas redes de contato foram formadas a partir de objetivos comuns. Estas foram indispensáveis para tornar viável o sucesso da expedição astronômica, e também para tornar viável o desenvolvimento da Astronomia na primeira metade do século XIX. Ademais, tais redes muitas vezes serviram a propósitos distintos, se estendendo em busca por informações comerciais que poderiam ser úteis a todos os países envolvidos.

\section{3 - Representações sobre o Chile}

No primeiro volume de seu relatório, Gilliss procurou descrever o país em sua "totalidade". Esperava-se que um relatório oficial fosse capaz de suprir seu país de dados variados sobre a região visitada. A história do Chile foi narrada com claros indícios de pesquisa pré e pós-viagem e também

\footnotetext{
${ }^{4}$ Cf: FIFER, Valerie. United States perceptions of Latin America, 1850-1930: A “New West" South of Capricorn?. Manchester: Manchester University Press, 1991. p.22.
} 
durante a mesma. Com isso quero dizer que muitas informações não foram obtidas pelo autor in loco.

Ao iniciar sua narrativa, o autor não mencionou a história anterior à invasão e colonização espanhola e relatou brevemente sobre os "desafios de seus desbravadores". Na sequência, iniciou uma longa descrição geográfica e política do país, sempre que possível seguidas de sua localização (latitudes e longitudes).

Não há, na maior parte do relato, uma escrita muito floreada, do tipo que agradasse ou chamasse à atenção do público não especializado, ainda que saibamos que cinco mil exemplares desse relatório foram impressos. Esse estilo de escrita é de se esperar de um cientista, responsável pelo relatório oficial da viagem. Ademais, embora fosse o seu dever suprir o relatório com o máximo de informações sobre o país, Gilliss só viajou quando seus olhos, afetados pelo grande número de horas observando o céu, o impediu de continuar com o programa de observações, sem fazer pausas. Portanto, é inegável que durante os anos de estadia no país ele se manteve focado no grande objetivo da expedição, qual seja, o astronômico. Ainda assim, centenas de páginas foram escritas sobre os mais variados temas.

Escolho nesse capítulo analisar as representações sobre o Chile envolvendo política, clima, religião, população e interesses geopolíticos e industriais. Também analiso as críticas ao relatório que foram feitas no período de sua publicação, além da sempre presente missão civilizadora a qual os Estados Unidos acreditavam ter para com a América do Sul.

Em seu relato, em qualquer parte do país por onde esteve, predominou o mesmo padrão de descrição e de críticas sobre a população, a Igreja, o governo e os políticos. O adjetivo apatia foi o escolhido para traçar o modo de ser dos chilenos, em quaisquer classes sociais. Veremos nas páginas que seguem como o autor descreveu e julgou a sociedade na qual esteve inserido por cerca de três anos. Para tanto, e considerando que o autor viajou pouco 
pelo país, escolhi realizar a análise do discurso e das representações construídas pelo oficial principalmente a partir das principais cidades chilenas, as quais ele visitou: Santiago, Valparaíso e Valdívia.

\subsection{1 - O clima e a apatia do chileno}

A avaliação de Gilliss sobre o clima é bastante antagônica. Veremos que o oficial, ao mesmo tempo em que o relacionou à apatia dos chilenos, o descreveu como muito agradável, além do país ter um excelente solo fértil. Se para a agricultura o solo e o clima chilenos eram perfeitos, para os homens seu prognóstico não se repetiu. Em seu relatório, em um subtítulo sobre o Chile denominado "Clima", o autor emitiu a seguinte opinião:

Todo viajante que chega para uma estada no Chile, sem afetação, elogia seu clima, não importa qual o período do ano em que sua visita foi feita. Suficientemente ao sul do equador a marcar perceptivelmente mudanças das estações, o Pacífico e o gigante Andes combinam-se para evitar extremos que os paralelos similares da costa atlântica norte estão sujeitos; e há uma uniformidade genial, muito gratificante à estrutura corporal, durante todo o ano. Se tal uniformidade é melhor para o desenvolvimento e o progresso da humanidade, eminentemente merece a atenção do fisiologista, instigado como ele é, para o inquérito, pelo fato de que as nações empreendedoras e enérgicas do mundo são aquelas que habitam climas sujeitos a vicissitudes frequentes e extremas. Não é a mente, como o corpo, mais inerte no verão e as suas percepções mais vivas e rápidas, quando as geadas de inverno demandam esforço físico vigoroso para aquecer o sangue? Se assim for, como podemos esperar grande energia de caráter, ou aquisições brilhantes, daqueles que nascem e habitam em climas que nunca experimentam essas mudanças? Que tal temperatura irá minar as energias do homem há ampla evidência entre os americanos e os europeus que residem por longo tempo no Chile; homens que foram para lá com toda a indústria, atividade e perseverança caracterizando suas raças, ainda que agora difiram pouco dos moradores nativos. Ativos como os membros da nossa pequena equipe foram obrigados a ser, e expostos, como costumamos dizer, ao frio mais severo já conhecido em Santiago, a residência de três anos causou uma impressão sensível até mesmo em nós; e um outro 
período similar provavelmente teria nos levado a nos impregnar com a apatia, característica nacional. ${ }^{5}$

Para o viajante, portanto, o que criava problemas para que o chileno fosse ativo era o fato de não haver mudanças consideráveis de temperatura, o que fazia com que o homem se acostumasse a um clima e não tivesse que se adaptar a outro, constituindo, assim, a variação da temperatura um fator decisivo para a atuação enérgica do homem. Ademais, para o oficial o clima do Chile não permitia a longevidade:

[...] na verdade, o Chile dificilmente pode ser considerado como um país favorável à longevidade; e já vimos que, segundo a interpretação mais favorável dos retornos do seu recenseamento, a população aumentou apenas três por cento, durante os últimos seis anos. Muita influência para afetar esse resultado tem os apetites e a dieta do seu povo; a possível atmosfera semi-estagnada dos vales profundos, onde não há nem fenômenos elétricos, nem ventos fortes para a sua renovação frequente; ou hábitos induzidos pela disposição apática, engendrado em um clima com tão poucas vicissitudes, são questões ainda não resolvidas pelos fisiologistas. ${ }^{6}$

\footnotetext{
${ }^{5}$ GILLISS, op. cit., Vol. I, p.80. No original: "Every traveller who has made a sojourn in Chile unaffectedly lauds its climate, no matter what the period of the year at which his visit was made. Sufficiently to the south of the equator to mark perceptibly changes of the seasons, the Pacific and giant Andes combine to prevent extremes to which similar parallels of the north Atlantic coast are subject; and there is a genial uniformity, most grateful to the corporal frame, throughout the year. Whether such uniformity is best for the development and progress of mankind, eminently deserves the attention of the physiologist, instigated, as he is, to the inquiry, by the fact that the enterprising and energetic nations of the globe are those who inhabit climates subject to frequent and extreme vicissitudes. Is not the mind, like the body, more inert in summer: its perceptions more vivid and quick, when the frosts of winter demand vigorous bodily exertion to heat the blood? If so, how can we expect great energy of character, or brilliant acquirements, from those who are born and dwell in climates that never experience such changes? That such a temperature will sap the energies of man, there is ample evidence among Americans and Europeans who reside long in Chile ; men who went there with all the industry, activity, and perseverance characterizing their races, yet who now differ little from native residents. Active as the members of our small party were compelled to be, and exposed, as we often were, to the severest cold ever known at Santiago, three years' residence made a sensible impression even on us; and another like period would probably have gone far towards imbuing us with the national trait apathy."

${ }^{6}$ GILLISS, op. cit., Vol. I, p. 92. No original: [...] "in truth, Chile can scarcely he regarded as a country favorable to longevity; and we have already seen that, under the most favorable interpretation of its census returns, the population has only increased three per cent, during the last six years. What influence to effect such a result have the appetites and diet of its people; the possibly semi-stagnant atmosphere of deep valleys, where there are neither electrical phenomena nor strong winds for its frequent renovation; or habits induced by the apathetic disposition engendered in a climate with so few vicissitudes, are questions not yet solved by their physiologists."
} 
Nos excertos acima podemos observar que a questão climática foi a base de seu prognóstico sobre o Chile, mas aqui seu discurso tomou nuances diferentes, se o comparamos com as representações que o oficial fez sobre o Panamá e o Peru. Para explicar a apatia chilena, Gilliss se apoiou nos fisiologistas do período e assim, manteve o clima como elemento principal para explicar alguns dos principais problemas do país. Mesmo não sendo um clima tropical - o cenário perfeito da indolência e da degeneração, de acordo com as teorias raciais do período - o Chile ainda guardava elementos dessa região, qual seja, a pouca variação de temperatura.

$\mathrm{O}$ autor, ao fazer as associações acima, se eximiu de maiores explicações sobre seu prognóstico e apontou que estas caberiam ao campo de estudos da Fisiologia, ciência que, em meados do século XIX, buscava compreender o funcionamento do corpo, bem como a ação do ambiente externo sobre ele. Ainda atrelado a outros campos de saber, especialmente à Medicina e à Etnologia, os fisiologistas da época buscavam em campos distintos de conhecimento os elementos para estudar e compreender seu objeto - o corpo humano - em estado dinâmico, vivo. Não era ainda uma disciplina completamente organizada e os fisiologistas do período, sem nenhuma identidade institucional formal, exerciam suas pesquisas inseridos ou associados a variados campos e instituições do saber. ${ }^{7}$

A Etnologia, por outro lado, havia fincado alguns alicerces no período em que Gilliss escreveu e tratava de forma bem mais aprofundada das questões levantadas pelo autor, como já discutido no capítulo três desta pesquisa. Definida como ciência que estudava a origem do homem e suas "raças" distribuídas pelo globo, atestava que características como a indolência eram típicas entre as regiões em que as altas temperaturas predominavam na maior parte do tempo e cujo inverno era ameno. Etnólogos do período

\footnotetext{
${ }^{7} \mathrm{Cf}$ : CRARY, Jonathan. Techniques of the observer: on vision and modenity in the nineteenth century. Massachusetts: Massachusetts Institute of Technology, 1992, p.79.
} 
defendiam, inclusive, que as "raças inferiores" se desenvolviam melhor nesses climas, dos quais eram originárias, diferentemente do que ocorria com a "raça superior", a branca, que em climas equatoriais ou tropicais, degenerava.

Os estudos desse campo foram amplos e frutíferos e ajudaram a legitimar ou justificar nos Estados Unidos a escravidão. No período em que Gilliss realizou a expedição ao Chile, como já dito, as discussões no campo da Etnologia se faziam presentes nos mais variados círculos científicos. ${ }^{8}$ Mas a associação de indolência, apatia e outros adjetivos depreciativos aos povos habitantes ou provenientes da América do Sul e da África subsaariana, por exemplo, não era privilégio apenas da comunidade científica. Tais conceitos ou preconceitos eram de domínio público, ainda que explicadas de diferentes maneiras e legitimadas pela ciência daquele período, como também já discutimos nessa pesquisa.

Embora o autor não se demore em justificar seu prognóstico, veremos que ele foi determinante nas construções de suas representações sobre o país. Mas, se analisarmos o clima chileno, veremos que a associação do autor entre clima e apatia não vai exatamente ao encontro das teorias vigentes, já que os estudos e prognósticos etnológicos feitos em sua época que associavam determinados tipos de clima à apatia, não se enquadram com o clima apresentado no Chile. A verdade é que para atestar o Panamá como negativo, Gilliss se apoiou em algumas teorias raciais vinculadas à Etnologia, mas no caso do Chile, amparou-se nos fisiologistas para atestar igual negatividade ao país sul-americano. No entanto, reitero que esses campos do saber estavam sendo delineados e que havia diálogo entre os pesquisadores que relacionava determinados climas às ações dos homens.

O Chile é um país com grande extensão em latitude, apresentando climas variados. No norte, onde está situado o deserto do Atacama, se observa

\footnotetext{
${ }^{8}$ Sobre o papel da Etnologia na legitimação da hierarquização das raças, ver: PAULINO, Carla Viviane. O papel da Etnologia norte- americana na construção de imagens e prognósticos sobre o Brasil e os brasileiros nos escritos de Thomas Ewbank. In: O Império do atraso, op.cit., pp.49-72.
} 
uma temperatura média de $18{ }^{\circ} \mathrm{C}$ e com pouca chuva. Na região central do Chile, o clima é o mediterrâneo, com temperatura média anual de $14{ }^{\circ} \mathrm{C}$. Na região sul do país, a temperatura cai e aumentam as precipitações, sendo Valdívia a cidade mais representativa desse tipo de clima temperado oceânico, que apresenta temperatura média anual de $12{ }^{\circ} \mathrm{C}$. O extremo sul do país, devido à grande altitude, é dominado por um clima subpolar. A região central do Chile, de clima mediterrâneo, corresponde ao clima de grande parte da Europa. Vemos, portanto, que o Chile apresenta uma variação climática, mas nenhuma sendo considerada equatorial ou tropical - principais temperaturas associadas à degeneração racial pelos etnologistas. Entretanto, os fisiologistas ofereceram a base para aquilo que o viajante referendou: a América Latina era um lugar com poucas condições de se tornar um espaço semelhante à América anglo-saxônica.

Com isso, confirmo o que afirmei no início deste subtítulo: o autor ofereceu a sua interpretação, que aliava de forma superficial as teorias do período aos preconceitos completamente introjetados no oficial sobre os homens da América do Sul, tão presentes em relatos de viagem e em estudos que se pretendiam científicos na época para validar a supremacia da raça anglo-saxônica sobre as demais e também a superioridade construída da América do Norte sobre a do Sul, para representar o Chile e a sua sociedade. Gilliss, assim, reproduziu apenas uma imagem que já estava consolidada no imaginário norte-americano e, com muita força, entre as elites do país, a qual ele pertencia.

Gilliss não levou em conta o longo período fora de casa e nem a atividade extremamente cansativa que se prestou a fazer diariamente, para justificar o cansaço, que certamente o fez sentir indolência e apatia, durante os três anos em que esteve envolvido em um extenuante projeto científico. Era mais fácil jogar para o "outro" ou sobre o clima a culpa de suas sensações do 
que avaliar a situação sob uma nova ótica. E foi assim, com o estereótipo da apatia, que Gilliss julgou a sociedade, como veremos nesse capítulo.

De fato, vimos que por um longo tempo, natureza e clima serviram como fatores cruciais na avaliação dos povos do Novo Mundo. Os Estados Unidos se esforçaram, principalmente no século XVIII e XIX, em se desvincularem de tais imagens e prognósticos negativos, na medida em que, tanto no campo da política como no das artes e no das ciências, se empenharam em refutar essas percepções europeias. Imputaram à América Ibérica essa imagem de degeneração, posto que eles, os irmãos do norte, construíram um novo prognóstico sobre a região, afirmando com palavras e imagens que, com a energia própria da "raça anglo-saxônica" associada a um clima semelhante ao europeu, foram capazes de domar a natureza ou o wilderness ${ }^{9}$ norte-americano, transformando-o em um importante elemento da identidade nacional — agora aliado do progresso do país. ${ }^{10}$

Nas Américas, a América Latina passou a carregar o fardo da degeneração e inferioridade. Aos Estados Unidos coube a "missão" de levar até eles o progresso e a civilização. Portanto, se não é possível afirmar de forma categórica que nesse período os Estados Unidos já assumiam uma ação política imperialista, as imagens construídas por norte-americanos sobre a América do Sul denotam uma cultura imperial que, junto à missão civilizadora, justificaram e legitimaram interesses políticos que já estavam presentes na primeira metade do século XIX

\footnotetext{
${ }^{9}$ De acordo com Mary Anne Junqueira, a palavra wilderness, que não possui tradução única para o português, pode abrigar variados significados, entre eles: selvagem ou o espaço do primitivo. Pode ser também relacionado a um estado de espírito. Nas palavras da autora, "A ideia de separação da Europa foi amplamente veiculada por políticos e representada por romancistas, poetas e pintores. A natureza, o wilderness norte-americano - principalmente o da região norte do país - que em alguns momentos da colônia era encarada como entrave para a modernização, dadas as dificuldades do clima frio, passou a ser entendida como algo que diferenciava a América da 'velha Europa' desgastada e decadente." Ver: JUNQUEIRA, Mary Anne. Oeste, Wilderness e Fronteira no imaginário norte-americano. IN: Ao Sul do Rio Grande - imaginando a América Latina em Seleções: oeste, wilderness e fronteira (1942-1960). Bragança Paulista: EDUSF, 2000. p.78.

${ }^{10}$ Sobre distintas visões da natureza nas Américas, ver PRADO, Maria Ligia. Natureza e identidade nacional nas Américas. In América Latina no século XIX. Tramas, Telas e Textos. São Paulo: Edusp, 1999.
} 


\title{
4.3.2 - A república chilena e a interferência do catolicismo
}

Como patrono da ciência, na estabilidade do governo e da prosperidade constantemente progressiva, o Chile está muito à frente de todas as outras nações da América do Sul. ${ }^{11}$

Como já dito, o relatório da Expedição não possui uma ordem de apresentação cronológica. O excerto acima foi extraído de outro volume do relatório, o de número três, posterior as suas descrições sobre o país, intitulado "Origem e operações da Expedição", no qual Gilliss narrou desde como nasceu a ideia da expedição até a sua chegada ao Chile e a montagem do Observatório. Neste capítulo, Gilliss teceu muitos elogios à forma como foi recebido pelo governo chileno, bem como o interesse do país em avançar com a ciência, como podemos observar no excerto acima. Dentre os países sul-americanos, o Chile era visto como exceção, como afirma Mary Junqueira. Em suas palavras,

\begin{abstract}
Importa ressaltar que esse "lugar comum" é reiterado ainda nos dias de hoje. Enquanto a maioria dos países hispano-americanos era visto como tomado pela inconstância, o Chile, por sua vez, era percebido como o lugar da estabilidade política e do crescimento econômico. $^{12}$
\end{abstract}

A autora analisou as representações do país principalmente com base nos relatórios de viagem de Charles Wilkes. Gilliss era um leitor dos relatos de viagem, e pesquisou muito sobre o país antes de decidir-se por instalar seu observatório no Chile. Wilkes é citado várias vezes em seu relato, e este, estando no país por apenas vinte e um dias na década de 1830, construiu sobre ele uma imagem bastante positiva. Gilliss, no entanto, produziu representações antagônicas sobre o Chile.

\footnotetext{
${ }^{11}$ GILLISS, op. cit. Vol. III, p. XXXI. No original: "As a patron of science, in stability of government and steadily progressive prosperity, Chile is far in advance of every other nation of South America."

${ }^{12}$ JUNQUEIRA, Mary A, op. cit., p.229.
} 
No período em questão, o Chile atravessava uma aparente fase de estabilidade política, conquistada através de um governo republicano liberal conservador, com fortes traços autoritários. Essa imagem de estabilidade era predominante no período entre as nações do mundo.

$\mathrm{Na}$ historiografia chilena, há autores que defendem esta estabilidade política após a sua independência, ressaltando que esta foi uma rara conquista entre os países que conquistaram sua independência, fato que colocou o Chile em lugar de destaque diante de seus vizinhos. ${ }^{13}$ Entretanto, a historiografia chilena não é unânime com relação a esta estabilidade. Historiadores como Gabriel Salazar defendem que tal imagem de estabilidade desprezou os constantes conflitos políticos e assim, consolidou tal característica como um mito fundador da nação. Para ele, tal estabilidade deve ser revista, já que o período de consolidação da nação chilena foi marcado por guerras civis, formação de movimentos de resistência ao governo controlado pela elite conservadora, nos quais variados grupos sociais se envolveram junto à elite intelectual e política de oposição, em busca do lugar que não lhes foi dado no projeto de consolidação do país. ${ }^{14}$ De fato, como veremos, o Chile não apresentou essa ordem durante parte do período em que Gilliss esteve por lá.

Entre 1831 a 1856, esteve à frente do governo chileno políticos oriundos da elite criolla conservadora, cujos governantes tinham como projeto manter e ampliar a chamada "civilidade chilena", usando de força militar e de supressão das liberdades. Entre 1841 e 1851, o país esteve sob a presidência de Manuel Bulnes, militar que governou durante esse período de forma bastante repressora e conservadora, controlando a imprensa e exilando os seus opositores, ao mesmo tempo em que promoveu o crescimento

\footnotetext{
${ }^{13}$ Ver, por exemplo, STUVEN, Ana Maria; PAMPLONA, Marco. Estado y nación en Chile y Brasil en el siglo XIX. Santiago: Ediciones UC, 2009

${ }^{14}$ Cf: SALAZAR, Gabriel. Construcción de Estado en Chile(1760-1860).Democracia de "Los Pueblos", Militarismo ciudadano, Golpismo Oilgárquico. 3a Ed. Santiago: Editorial Sudamericana, 2011. p.14-15.
} 
econômico do país. ${ }^{15}$ Ao fim de seu segundo mandato, protestos contra as duras regras do regime se espalharam pelo Chile, culminando em uma rebelião com o propósito de derrubar Bulnes e impedir que seu protegido, Manuel Montt Torres, o sucedesse. Gilliss e sua equipe vivenciaram em 1851 esse período turbulento, que terminou com a derrota dos revoltosos pelo exército de Bulnes, o qual trataremos adiante.

Nas páginas que seguem, veremos que suas descrições fazem com que os elogios ao Chile tecidos por ele em raras ocasiões, não se sustentem como sendo de fato a sua visão sobre o país. Sua opinião de forma geral se mostrou elitista, negativa, ambígua, contraditória e preconceituosa. $\mathrm{O}$ excerto a seguir demonstra a visão predominante no relatório sobre o governo e seu povo, após um período vivendo no Chile:

\begin{abstract}
Nominalmente uma república, o governo é, na realidade, uma ditadura militar — provavelmente a única forma que poderia durar seis meses com uma raça muito orgulhosa e apática para o trabalho, e que enredou a revolução na esperança de que eles próprios e os amigos pudessem obter gabinetes e rendimentos. Aparentemente, $o$ desejo por um gabinete é a única razão para agitações constantes em toda a América espanhola. Alcançados os princípios almejados pelo partido, aqueles que lutaram por isso seriam agraciados. Tal não é o caso em qualquer dos governos sob o controle de populações espanholas; e tão logo um chefe é elevado à autoridade suprema, já há um novo que começa a miná-lo. Sem dúvida, o Chile é o mais estável de todos eles; mas a república não pode permanecer estável e verdadeiramente republicana com o demônio [Íncubo] de uma única religião sentado sobre o pescoço da sua população. Todos esses líderes revolucionários, eventualmente, "deixaram seu país para o bem de seu país". ${ }^{16}$
\end{abstract}

\footnotetext{
${ }^{15}$ Cf: SALAZAR, Gabriel; PINTO, Junior. História Comtemporanea de Chile. Vol. I, Santiago: LOM Ediciones, 2012.

${ }^{16}$ GILLISS, op. cit., Vol. I, p. 480. No original: "Nominally a republic, the government is in reality a military dictatorship - probably the only form which could last six months with a race too proud and apathetic for labor, and who plot revolution in the hope that themselves and friends may obtain offices and incomes. Apparently, a craving for office is the only reason for constant agitations throughout Spanish America. If the success of principles were sought, at its consummation those who had striven for the elevation of their party would be satisfied. Such is not the case in any of the governments under the control of Spanish populations; and no sooner is one chief elevated to supreme authority than a new one begins undermining him. Undoubtedly Chile is the most stable of them all; but she can never remain long truly republican with the
} 
No excerto que acabamos de ler, encontra-se uma espécie de resumo de todos os problemas do Chile, sob o ponto de vista de Gilliss. Dentre eles, vemos a menção das constantes tentativas de minar a estabilidade política com rebeliões ou com o que ele chamou de revolução - a qual presenciou que, para Gilliss, eram movidas pelos interesses próprios de quem as articulava. No entanto, sabemos que houve movimentos distintos buscando suprimir o governo em busca de um projeto político que incluísse e beneficiasse a população comum, como a revolta promovida por um grupo chamado Igualistas, a qual, como acabo de afirmar, ele presenciou.

No início da década de 1840, reuniu-se no Chile uma geração de intelectuais liberais que discutiram a construção da nação sob outro prisma, o da educação. Nomes como Andres Bello, Domingos Faustino Sarmiento, Vicente Lopes, Juan Bautista Alberdi, Francisco Bilbao reuniram-se em torno de ideias liberais e ficaram conhecidos como a geração de 1842. O objetivo desses intelectuais era implementar as ideias liberais pelo caminho da educação e cultura, única possibilidade que poderia, segundo eles, dirimir os conservadores e a sua mentalidade conservadora do período. ${ }^{17}$

Aqui, considero importante também explicitar a revolta citada por Gilliss no excerto que estamos analisando. Em 1851 ocorreu uma revolta liderada pelos membros da Sociedad de la Igualdad, formada por alguns dos intelectuais acima citados, a qual teve grande participação de artesãos. Essa revolta caracterizou-se pela revolta de membros dessa sociedade, formada por intelectuais como Francisco Bilbao e por muitos artesãos chilenos, que se colocaram contra as eleições de 1851 de Manuel Montt, pois que a consideraram fraudulenta. Este grupo também reivindicava por uma sociedade mais igualitária e lutavam em busca de maiores direitos civis.

incubus of any exclusive religion about the necks of her people. All of these revolutionary leaders eventually "left their country for their country's good."

${ }^{17}$ Cf: STUVEN, Ana María. La seducción de un orden. Las elites y la construcción de Chile en las polémicas culturales y políticas del siglo XIX. Santiago: Ediciones de la Universidad Católica de Chile, 2000. 
Embora o número de insurgentes nesta revolta tenha sido grande e mobilizado as principais cidades chilenas, o governo conseguiu suprimi-la, a custa de centenas de mortes.$^{18}$

Mas Gilliss, que manteve contato com parte dessa elite, não considerou de forma séria esse movimento ao discutir a política do país, como acabamos de observar em seu excerto. Voltemos à interpretação do excerto acima, abordando agora sua crítica à religião.

O incubus (íncubo) é retratado como um tipo de pesadelo, no qual um demônio - denominado Íncubo — senta sobre o dorso de uma jovem, enquanto ela está adormecida, com a intenção de abuso sexual. A metáfora de Gilliss é, portanto, repleta de significados. O Chile personificaria a jovem, que está vulnerável por um profundo sono, enquanto a Igreja Católica simbolizaria o demônio abusador, que sufoca e explora o país.

O oficial também culpou a própria população, apática e indolente, pelo tipo de governo autoritário que possuía. Se o povo não era digno de viver regido por uma "autêntica república", a elite do país tampouco, já que passavam por cima dos ideais republicanos e de suas virtudes e eram capazes de enredar revoluções não por princípios políticos, mas sim por interesses próprios, buscando o enriquecimento através do poder político alcançado, caso obtivessem êxito. ${ }^{19}$ Mais uma vez, essas afirmações não se sustentam por completo quando lembramos da revolta por ele presenciada, na qual envolveu principalmente a classe de trabalhadores artesãos. No entanto, o oficial manteve a visão de que o Chile era o país mais estável da América Latina, apesar dos problemas políticos e mesmo atrelado a uma Igreja que reconhecia uma única religião como admissível no país.

Não satisfeito, Gilliss questionou a legitimidade do governo eleito:

\footnotetext{
${ }^{18}$ Cf: GAZMURI, Cristián. El "48" Chileno: Igualitarios, Reformistas, Radicales, Masones y Bomberos. Santiago del Chile: Editorial Universitaria, 1999.

${ }^{19}$ Sobre o sentido de República associada á virtude cívica, ver: PAULINO, Carla Viviane, op. cit. cap.3.
} 
[...] a lei é letra morta, ou pelo menos é abertamente violada a cada eleição; e assim, enquanto há um republicanismo nominal, e urnas nas quais o sentimento público pode ser expresso, o resultado de cada eleição é tão perfeitamente conhecido com antecedência em Santiago, que os preparativos para isso são feitos com toda a confiança. $^{20}$

Não bastasse a ditadura, a Igreja Católica atrelada ao governo e sua gente apática, a "suposta república" elegia seus governantes de forma desonesta, não prevalecendo os resultados das urnas. Aqui, novamente, lembro o leitor que parte da população se manifestou contra esse tipo de fraude.

O país, como já dito, de fato passava por um governo que podemos caracterizar como uma República liberal conservadora, cujo presidente, Manuel Bulnes, que governou o país entre 1841-51, como já citado, era um militar que foi eleito através do voto censitário. Assim, temos um regime republicano, com um presidente autoritário, que promoveu em 1833 uma constituição autoritária. O que pesava para Gilliss eram as eleições fraudulentas, as ações enérgicas por parte do governo em reprimir seus opositores, a afirmação da Igreja Católica na Constituição do país como exclusiva no Chile, a conduta dos políticos que não apontam para o modelo de virtude cívica republicana e a forte presença da Igreja no Estado.

Independente da Espanha em 1818, o Chile buscava naquele momento a consolidação do Estado Nacional da nação em meio a uma atmosfera política tensa, na qual seus governantes buscavam manter a estabilidade política adquirida desde a década de 1830 a qualquer preço. Mesmo após a independência, o Chile permaneceu por muito tempo com uma população

\footnotetext{
${ }^{20}$ GILLISS, op. cit., Vol. I, p. 129. No original: [...]"the law is a dead letter, or at least is openly violated at every election; and thus, whilst there is nominal republicanism, and a ballot-box through which public sentiment may be expressed, the result of every election is so perfectly well known in advance at Santiago, that preparations are made for it in all confidence."
} 
predominantemente rural e de economia agrícola. No entanto, sua economia crescia. O Chile era até o fim da primeira metade do século XIX um exportador considerável de trigo e de farinha, cujas exportações cresceram muito nesse período devido à corrida pelo ouro na Califórnia e da Austrália, além de alcançar países como a França. Ademais, não se pode deixar de lado a exploração de minérios já que, segundo Peter Winn, era a principal fonte de renda de exportação chilena, principalmente a mineração de prata e cobre. ${ }^{21}$

Os governos conservadores chilenos desse período são marcados pelo êxito no controle de rebeliões e pelo avanço do país, cujo caminho tomado para atingir o crescimento foi, de modo resumido, o investimento em policiamento a fim de manter a pacificação, a busca por colonização de áreas pouco povoadas, a educação e o desenvolvimento econômico. Foi este Chile, que começava a se "preparar para o progresso", que Gilliss encontrou. Mas este Chile, cuja elite criolla se mantinha no poder, tinha, como já dito, seus opositores, fato que o oficial não descreveu ou discutiu com o devido cuidado. Ademais, creio o viajante olhou o país com as lentes da república norteamericana que ele conhecia. Ainda que governos autoritários devam ser duramente criticados, o Chile não pode ser interpretado apenas por esse viés. Certamente Gilliss teve contato com a elite política que não pertencia à ala conservadora, mas, como já dito, o oficial ignorou esta lado da política e dos intelectuais chilenos em seu relatório. Entretanto, o autoritarismo, a corrupção e a interferência da Igreja no Estado serviram de base para o viajante inviabilizar o país. Nenhum país na época era modelo de conduta. Nos Estados Unidos, na época da viagem de Gilliss, abria-se o fosso entre Norte e Sul, que acabaria na sangrenta guerra que deixou o país de joelhos.

Passemos agora a entender o cenário que envolve política e religião. Como já dito, um dos pilares do governo conservador chileno era manter a estabilidade política e social. Para isso, havia a necessidade de um elemento

\footnotetext{
${ }^{21}$ Cf. WINN, Peter. A Revolução chilena. São Paulo: Unesp, 2009. p.32.
} 
de ação na sociedade, capaz de manter a ordem, a conformidade e a aceitação dos passos dados pelo governo. Com a educação ainda por ser desenvolvida a contento e a fim de tornar a população esclarecida e apta, de acordo com o pensamento da época, a agir politicamente e em sociedade de forma racional, parte da elite criolla concordava com o fato de que a Igreja era a única instituição capaz de manter a população em um estado de ordem e resignação desejados e necessários para preservar a estabilidade política. Isso explica a forte presença da Igreja na vida cotidiana e na política, situação que incomodou Gilliss. ${ }^{22}$ No entanto, isso não significa que não houvesse discordâncias nesse sentido, como vimos. No Chile, havia políticos e intelectuais que acreditavam na necessidade da formação de um Estado laico, com a melhoria de condições da população chilena, e estes, não se encaixavam no padrão acima descrito.

Além desse ponto, o oficial não aceitava o fato de a Constituição chilena reconhecer a Igreja Católica como exclusiva e excludente, já que proibia o direito de escolha dos chilenos de praticar qualquer outra religião. Essa proibição indignou esse viajante. Acredito que tal olhar esteja baseado na forma como política e religião eram tratadas pelo governo em seu país. Aqui, considero pertinente tecer algumas considerações sobre o tema e demonstrar que, apesar de Gilliss não mencionar, também nos Estados Unidos religião e política, de certa forma, andaram juntas.

Naquele país, as igrejas protestantes se engajaram na defesa dos ideais republicanos. Esse comprometimento muitas vezes foi forte o bastante para que missionários tomassem para si a tarefa de levar para dentro e fora do país a doutrina política que para eles, era a única capaz de representar os valores

\footnotetext{
${ }^{22}$ Sobre o papel da Igreja no Chile de meados do século XIX, Cf: PINTO, Julio; VALDIVIA, Verónica. ¿Chilenos todos? La construcción social de la nación (1810-1840). Santiago: Lom Ediciones, 2009.; SALAZAR, Gabriel. Construcción de Estado en Chile (1760 - 1860): democracia de "los pueblos" militarismo ciudadano golpismo oligárquico. Santiago de Chile: Editorial Sudamericana, 2005.; STUVEN, Ana María. La seducción de un orden. Las elites y la construcción de Chile en las polémicas culturales y políticas del siglo XIX. Santiago: Ediciones de la Universidad Católica de Chile, 2000.
} 
morais e sociais condizentes com a doutrina cristã e protestante. Havia, portanto, um esforço por parte das igrejas e de muitos políticos em construir uma identidade nacional que somava os ideais da república aos do protestantismo. $^{23}$

A historiadora Cecília Azevedo nos esclarece sobre o peso do protestantismo na cultura norte-americana ao demonstrar a importância de seu papel da formação da nação até os dias atuais, já que a religião exerce até hoje um papel fundamental na história e nas ações políticas dos Estados Unidos, país cujo sistema político parece estar indissociado de sua fé. ${ }^{24}$ Azevedo mostra como política e religião se uniram nos Estados Unidos em uma espécie de articulação que girava em torno da defesa de projetos específicos, bem como de propor moralidade na política, ainda que as igrejas estivessem, desde a independência norte-americana, separadas do Estado. Esse é um fator crucial para Gilliss, já que nos Estados Unidos o governo não estava formalmente vinculado a uma religião e não estava obrigado a servir aos interesses das igrejas sob nenhuma circunstância. Foi esse estranhamento, esse vínculo formal com o Estado, que causou indignação no viajante e fomentou suas críticas.

Esse incômodo não é incomum entre viajantes norte-americanos. Thomas Ewbank, por exemplo, viajante que esteve no Brasil, mais especificamente no Rio de Janeiro em 1846, demonstrou a mesma intolerância ao catolicismo e sua forte presença no Estado. Enquanto que para Ewbank, o protestantismo e o regime político republicano eram os mais condizentes com os mais altos graus de civilização, para Gilliss, o grande incômodo, como vimos, era o alto grau de interferência e de poder que a Igreja exercia no campo da política, da sociedade e da vida cotidiana. No

\footnotetext{
${ }^{23}$ Cf: PAULINO, Carla Viviane. O Império do atraso: Etnologia, Política e religião nas impressões sobre o Brasil de um inglês radicado nos Estados Unidos (1846-1856). 1a. ed. São Paulo: Alameda, 2014. pp. 87-93. ${ }^{24}$ AZEVEDO, Cecília da Silva. "A santificação pelas obras: experiências do protestantismo nos EUA". Revista Tempo: Rio de Janeiro, n.11, pp. 111-129.
} 
entanto, ambos não foram capazes de perceber ou de admitir que religião e política, como vimos, estabeleceram uma importante parceria informal em seu próprio país.

Ocorre, como já dito, que Gilliss é contraditório em suas críticas. Se acima, pudemos analisar as razões pelas quais ele constrói uma imagem negativa do governo e de seus governantes, em um excerto extraído de um capítulo destinado exclusivamente a descrever o governo chileno, Gilliss praticamente afirmou o oposto do que vimos e discutimos, com exceção da religião:

Poucas nações têm demonstrado visões tão amplas e liberais, tanta vontade de superar e meritoriamente comandar a admiração dos contemporâneos. Apresentando à humanidade o espetáculo de um governo estável e sistemático, do clima e do solo insuperável, um mercado lucrativo para os produtos estrangeiros e nacionais, a proteção de todas as atividades industriais, mais do que o mecenato régio para a ciência e arte, há ainda, porém, dois outros atos legislativos que parecem necessários para avançar a riqueza moral e material e o crescimento populacional em proporções sem precedentes. São eles: a abolição das leis do dízimo e da igreja exclusiva; ambas as quais, como atualmente administradas, são desmoralizadoras e suicidas a um nível que somente pode ser compreendido por aqueles que desejam que o Chile ocupe um lugar entre as nações, em que os seus números, cultura, instituições liberais e riquezas lhe permitissem ocupar. ${ }^{25}$

Surpreendentemente, o autor mudou de opinião. Gilliss, definitivamente, era um homem contraditório. O governo, sem virtudes, passou a tê-las e vai além: antes descrito como ditatorial, agora é liberal. O clima, que antes proporcionava apatia aos habitantes, agora é fantástico e

\footnotetext{
${ }^{25}$ GILLISS, op. cit., Vol. I, p. 141. No original: "Few nations have shown such broad and liberal views, such meritoriously emulous desire to command the admiration of contemporaries. Presenting to mankind the spectacle of stable and systematic government, unsurpassed climate and soil, a profitable market for foreign and domestic products, protection to all industrial pursuits, more than regal patronage to science and art, but two further acts of its legislature seem necessary to advance the moral and physical wealth and population in unprecedented ratios. These are: abolition of tithe laws and the exclusive church; both of which, as at present administered, are demoralizing and suicidal to a degree appreciable only by those who long to see Chile occupy the rank among nations to which numbers, culture, liberal institutions, and wealth would entitle her."
} 
insuperável. Não há aqui explicações lógicas para tal mudança de opinião. O único julgamento que se mantém é com relação à interferência da Igreja na esfera pública. E mais, este, na verdade, passou a ser o único aspecto faltante para tornar o Chile um país excepcional.

Aqui, reitero novamente a importância do cuidado e atenção ao manejar este tipo de fonte, que muitas vezes diz mais sobre o viajante do que sobre o local visitado. Assim como qualquer documento, este não reflete necessariamente uma realidade precisa. Olhando com atenção, podemos inferir que no último excerto, Gilliss reconheceu o desejo do país e seus esforços em direção à outra perspectiva de governo, provavelmente o projeto já indicado da geração de intelectuais de 1842. Mas se pensarmos que relatos oficiais como estes têm o importante papel de posicionar seu país sobre o funcionamento de outro, o relatório peca pela imprecisão e pela contradição na medida em que o autor apresentou visões opostas sobre um mesmo tema.

\subsection{3 - Os "limites" da sociedade chilena}

Os primeiros aspectos da sociedade analisados neste capítulo trataram do clima do país considerado pelo viajante como degenerador e dos problemas do governo e da prática política no Chile e sua associação com a religião católica. Vejamos agora como Gilliss construiu a representação sobre a sociedade chilena em seus mais variados aspectos.

Assim que o oficial aportou no país, as primeiras impressões negativas foram tecidas. Enquanto viajava de Valparaíso em direção a Santa Lucia, o oficial observou a paisagem, as pessoas e suas casas:

À beira da estrada, as habitações do campesinato são de desconsolada descrição; [...] Os ocupantes estão em consonância com elas, uma raça morena e impura, cuja cada característica e movimento denunciam falta de energia e inteligência. De altura moderada, com membros bem formados, embora pequenos, maçãs 
do rosto razoavelmente proeminentes e cabelos pretos e lisos, sua origem não pode ser confundida $\left[\ldots . .{ }^{26}\right.$

Novamente, se faz presente uma descrição de um povo miscigenado, indolente e pouco inteligente. $\mathrm{O}$ viajante parecia gostar de assemelhar as moradias como reflexo de quem as habita, já que analisou os habitantes do Panamá da mesma maneira, como já vimos. Quanto mais precárias as habitações, mais inferiores os seus habitantes. Notamos também uma descrição da mistura de "raças" com as quais ele encontrou em sua viagem, cujo tom é predominantemente formado por preconceitos, muito embora tais descrições dos indígenas e latinos em geral como inferiores estejam, como já afirmado anteriormente, em consonância com a visão científica da época.

Sobre a população de Santiago, assim como das demais cidades, as classes baixas foram sempre mencionadas como descuidadas, "impuras". ${ }^{27}$ Suas casas e seus modos para ele refletem a sua origem racial, e não a falta de condições básicas de saneamento e oportunidades de estudo, trabalho e cuidados que se restringem as elites locais:

Descuidados e impuros tanto como os hábitos das classes mais
baixas são conhecidos, e tão essencial quanto é para conforto e
saúde para preservar um fluxo rápido, embora a cidade forneça
carrinhos de miudezas grátis que passam diariamente em cada casa,
os regulamentos da polícia para prevenir corpos estranhos que
estão sendo jogados dentro deles são totalmente ignorados, e os
conteúdos dos drenos devem ser tirados através da casa de vez em

\footnotetext{
${ }^{26}$ GILLISS, op.cit. Vol. I, p. 452. No original: "By the roadside, the dwellings of the peasantry are of the most comfortless description [...] The occupants are in keeping with them a swarthy and unwashed race, whose every feature and motion betray want of energy and intelligence. Of moderate height, well formed though small limbs, tolerably prominent cheek-bones, and straight black hair, their origin cannot be mistaken."

${ }^{27}$ Sobre Santiago, Gilliss, na parte destinada a descrição geográfica do Chile, dedicou quarenta e oito páginas a esta cidade, e depois, no mesmo volume, mais vinte e seis páginas para escrever sobre ela novamente. Como já dito, o relato foi construído sem uma lógica ou condensação de experiências. À medida que o autor viajava, por exemplo, um novo capítulo era escrito e apresentado no relatório, fato que explica Santiago ser analisada por Gilliss em dois capítulos distintos e distantes entre si.
} 
quando, a pilha fétida muitas vezes permanece por dias à porta da frente. ${ }^{28}$

Aqui, o autor se referia ao mau cheiro decorrente do constante entupimento nas saídas de esgoto, as chamadas acéquias, e ao recolhimento de lixo. Notamos que Gilliss julga a questão como reflexo da ausência de cuidado por parte da população pobre que parecia não se importar em viver em tais condições e que inclusive, era a responsável pela situação, já que, apesar da passagem de carrinhos para recolher miudezas, o oficial aponta que a população as jogava no esgoto. Fica a dúvida aqui sobre se, de fato passavam diariamente nas casas e em que horas isso ocorria. Considerando sua última frase, em que se acumula lixo por dias na frente das casas, a informação por ele fornecida sobre a passagem diária de coletores de lixo não se sustenta.

Por outro lado, muitas vezes o autor se referiu aos homens das classes mais baixas que dominavam alguma profissão artesanal ou mecânica, como eram chamados na época pelos norte-americanos, para comparar sua alta remuneração com relação aos norte-americanos. A escassez de mão de obra qualificada tornava os produtos caros e de acordo com Gilliss, os chilenos ganhavam muito mais, trabalhando metade do tempo despendido por um norte-americano. A quantidade de vezes em que o oficial realizou esse tipo de comparação não somente no Chile, mas em outros países em que passou, indica oportunidades para os norte-americanos no lugar:

Pode-se dizer com segurança que os carpinteiros obtêm pelo seu trabalho, pelo menos quatro vezes o valor pago aos artesãos similares na América do Norte; sendo os seus salários dobrados, enquanto a quantidade de trabalho realizado em um dia não é mais

\footnotetext{
${ }^{28}$ GILLISS, op. cit., Vol. I, p. 179. No original: "Careless and unclean as the habits of the lower classes are known to be, and essential as it is to comfort and health to preserve a rapid flow, although the city supplies offal-carts gratis that call daily at each house, the police regulations to prevent extraneous matter being thrown into them are wholly disregarded, and the contents of the drains must be brought through the house from time to time, the odorous heap often lying for days before the front door."
} 
do que a metade. Nessas contas, seria verdadeira economia ter toda a madeira trabalhada das casas sendo preparada nos Estados Unidos ou na Europa e enviadas para Valparaíso. ${ }^{29}$

Vemos a sugestão de empreendimento para norte-americanos ou europeus. É sabido que nos Estados Unidos esse tipo de mão de obra possuía um valor simbólico muito associado ao progresso. Os chamados "mecânicos" norte-americanos foram muitas vezes aqueles que patentearam novos instrumentos de trabalho, criaram novas técnicas e foram os responsáveis por grandes inventos no país. Essa imagem do homem inventivo, valorizada nos Estados Unidos, certamente influenciou o olhar diferenciado de Gilliss para essa camada da população, mas não aos do Chile, e sim aos de seu país, já que sugere que estes, ou mesmo os europeus, enviassem seus produtos ao país. Aos artesãos locais, restou sua indignação pelos altos preços cobrados por seus serviços, como vimos. ${ }^{30}$ No entanto, vimos que havia um movimento importante de artesãos no país, forte o suficiente para, junto com a elite de oposição ao governo conservador, iniciar uma revolução no Chile.

Sobre as condições da educação de grande parte dos chilenos, afirmou que a maioria era analfabeta e, os que não o eram tinham pouco acesso à leitura, já que "os poucos que sabem ler ou escrever não têm jornais ou livros, sendo até mesmo a Bíblia proibida para eles". ${ }^{31}$ Quanto à política, esta estava sob o controle dos grandes fazendeiros e mineiros do país, que decidiam as eleições. Mais uma vez, Gilliss ignorou o trabalho de intelectuais como Andres Bello e Domingo Sarmiento no campo da educação.

Gilliss optou por mostrar o grau de ignorância a que a população estava submetida bem como a força da elite conservadora em dar rumos políticos ao

\footnotetext{
${ }^{29}$ GILLISS, op. cit., p. 180, Vol. 1. No original: "It may safely be said that the carpenters obtain for their labor at least four times the amount paid to similar artisans in North America; their wages being double, whilst the amount of work accomplished in a day is not more than one half. On these accounts, it would be true economy to have all the wood-work of houses prepared in the United States or Europe and shipped to Valparaiso."

${ }^{30}$ Sobre este tema ver: PAULINO, Carla Viviane, op.cit., p.132-143.

${ }^{31}$ GILLISS, op. cit., Vol. I, p. 129. No original: "The few who can read or write are without newspapers or books; even the Bible is prohibited to them."
} 
país, a despeito da vontade da maioria. No entanto, com relação à educação, já estava em implantação um sistema comprometido em preparar a população e as gerações vindouras. Assim, se por um lado é perfeitamente admissível para o período o fato de que poucos sabiam ler, por outro, me parece duvidosa a afirmação do autor de que viviam em completa ignorância. Sabemos que as ideias circulavam, tanto quanto as notícias. Ademais, sabemos que a população esteve junto aos políticos e intelectuais de oposição em diversos movimentos contrários ao governo, como afirma Gabriel Salazar. Portanto, ainda que a elite criolla conservadora estivesse à frente de movimentações políticas, essas nem sempre ocorriam sem que a população tivesse ciência do que estava acontecendo. Salazar, como já vimos, demonstra a participação direta do povo, o que desqualifica a avaliação feita por Gilliss, inclusive com relação ao fato de que a população não se importava em ser mais ativa politicamente.

Embora tenha separado um subtítulo apenas para discutir a política e o governo chileno, demonstro aqui como Gilliss foi manchando a imagem do chileno em cada camada da população. Aos políticos, coube a desonestidade e falta de comprometimento com o país. Ademais, a apatia chilena foi vista pelo autor em todas as camadas sociais, inclusive entre estes. E como contraponto a essa falta de energia, Gilliss mencionou os anglo-saxões:

É tão diferente de uma assembleia de anglo-saxões que se reúnem para discutir as questões da nação, quanto possível; pois não há eloquência, nem entusiasmo, na verdade há apenas um pouco mais de vida entre esses oradores [chilenos] do que em uma reunião de Quakers moderados. ${ }^{32}$

\footnotetext{
${ }^{32}$ GILLISS, op. cit. Vol. I, p. 131. No original: It is as unlike an assemblage of Anglo-Saxons met to discuss the affairs of the nation as possible; for there is no eloquence, no animation indeed scarcely more life among the speakers than a moderate Quaker meeting offers.
} 
As reuniões de Quakers, a qual Gilliss fez referência, eram, e ainda são, consideradas extremamente monótonas por não praticantes. Isto porque, nessas assembleias, os participantes se sentam em silêncio absoluto, esperando serem "movidos", "incentivados" por Deus para se levantarem e expressarem seus pensamentos e sentimentos.

A imagem acima aponta para a ideia de políticos pouco motivados para agir em prol da nação. Inclusive, era o oposto dos enérgicos anglo-saxões. É como se o único retrato possível de ser pintado sobre o homem chileno fosse o da falta de ação, da indolência e da apatia. Aqui, novamente seu discurso nega os elogios feitos por ele no próprio relato sobre aquela nação, que estava em constante progresso e que era dirigida por esses mesmos homens "desprovidos de vontade". Sabemos, no entanto, que no período em que Gilliss esteve no Chile o governo já enfrentava duras oposições, de caráter popular, cujos líderes lutavam por liberdade de expressão e maior atenção às camadas pobres da população. Jose Victorino Lastarria, importante intelectual do período foi um de seus principais representantes na política, exercendo diversos cargos políticos ao longo de sua vida, incluindo um mandato como deputado, no período em que Gilliss lá esteve, e que se caracterizou como nada apático. ${ }^{33}$

Se aos políticos nenhuma virtude foi atribuída, tampouco aos fazendeiros e seus peões:

Então, também, de acordo com o exemplo dado por um grande número de seus empregadores, os peões que cultivam o solo são indolentes ao extremo, e totalmente imprevidentes. ${ }^{34}[\ldots]$ Uma raça descuidada, preguiçosa, dada a embriaguez e sensualidade sempre que ocasiões são apresentadas. ${ }^{35}$

\footnotetext{
${ }^{33}$ Cf: SUBERCASEAUX, Bernardo. Historia de las ideas y la cultura en Chile. Tomo 1, Santiago: Editorial Universitária, 1997. pp.120-121.

${ }^{35}$ GILLISS, op. cit., Vol. I, p. 463. No original: "Then, too, in accordance with the example set by large numbers of their employers, the peons who cultivate the soil are indolent in the extreme, and utterly improvident[...] A lazy, careless race, given to ebriety and sensuality whenever occasions are presented."
} 
O interessante aqui é notarmos que Gilliss novamente não poupou a elite pelos males do país. Os peões seguem o exemplo de seus patrões fazendeiros, muito embora os piores adjetivos ele sempre reservou aos de classe mais baixa.

Gilliss preferiu omitir a condição de seu próprio país, cujas fazendas eram abastecidas por mão de obra escrava, e cujos patrões possuíam energia o bastante não para o trabalho, mas para os destratos e desmandos, ou para agir quando em prol de interesses próprios. No Chile, não havia mais escravidão, mas devemos lembrar que sua população ainda carecia de uma série de medidas educacionais e de um governo que lhes possibilitasse maior leque de escolhas. Ainda que muito do que Gilliss descrevesse seja validado por historiadores contemporâneos, notamos que o viajante foi parcial, na medida em que, mesmo sabendo da existência de uma elite política que ia em direção oposta aos criollos conservadores. Gilliss, ao focar nos problemas e nos políticos corruptos em seu relato, não deixou espaço para seus opositores e assim, se esmerou em demonstrar um país com muito mais problemas do que virtudes.

Sobre os homens da alta sociedade, o oficial procurou explicar a resistência em criar vínculos mais estreitos com estrangeiros devido à insegurança que sentiam quando próximos a eles, os de sangue anglo-saxão:

Seus hábitos e disposições torna-os avesso à relação com os estrangeiros em geral, de quem eles são, sem dúvida, ciumentos, tanto por causa da educação superior, a inteligência e a energia desses últimos $[\ldots] .{ }^{36}$

Não satisfeito com a representação do homem chileno como ciumento e consciente de sua inferioridade com relação aos estrangeiros (europeus e

\footnotetext{
${ }^{36}$ GILLISS, op. cit. Vol. I, p. 131. No original: "Their habits and dispositions make them averse to intercourse with foreigners generally, of whom they are undoubtedly jealous, as well because of the superior education, intelligence, and energy of the latter"[...]
} 
norte-americanos), Gilliss, em plena metade do século XIX, afirmou que as mulheres chilenas eram superiores em relação aos homens do país:

Possuindo habilidades naturais finas [...] não se pode deixar de contrastá-las com seus compatriotas apáticos e geralmente mal instruídos. $^{37}$

Tal afirmação, um tanto quanto inusitada para os padrões da época, parece vir carregada de implicâncias para com o homem chileno, especialmente os da elite, que ao que parece, não manifestaram interesse em desenvolver uma relação mais próxima com o capitão da expedição astronômica. O oficial MacRae dá indícios em seu relato de que eles não desfrutaram de grande prestígio em sua estadia de três anos no Chile, de modo que este descaso provavelmente irritou ainda mais Gilliss, a ponto deste colocar as mulheres, sempre mais simpáticas e interessadas, como superiores aos homens. Certamente Gilliss sabia o tamanho da afronta que cometia e ainda assim, decidiu por manter essa afirmação. Se de fato houve pouca receptividade para com os oficiais da expedição, penso que aqui está a "vingança" do oficial, que colocou esses homens abaixo das mulheres.

Por outro lado, ao mesmo tempo em que elogiou as mulheres do Chile, o oficial retratou as relações maternais de um modo que passa-nos a impressão de que naquele país, as relações entre mãe/filho (a) não eram fundamentadas no afeto. Segundo o autor, tão logo nasciam, as crianças eram levadas por uma "enfermeira", que cuidaria das crianças em clima mais apropriado para o crescimento saudável das mesmas. Assim sendo, as mães não criavam seus filhos, fato que levaria a uma série de problemas: do alto índice de mortalidade infantil devido a maus tratos e descuido, à falta de laços de confiança e afeto familiares. Paradoxalmente, a mulher que Gilliss elogiou era também culpada por não exercer sua função de mãe nos primeiros anos de

\footnotetext{
${ }^{37}$ GILLISS, op. cit, Vol. I, p. 144. No original: "Possessing fine natural abilities, [...] cannot fail to contrast them with their apathetic and generally ill instructed countrymen."
} 
vida dos filhos e assim, formar famílias cujos filhos não confiavam em seus pais, já que não eram criados no seio familiar durante a infância. Obviamente, o autor, embora não explique, está se referindo as classes mais abastadas, já que os pobres não tinham meios de pagar uma enfermeira para levar seus rebentos para "climas apropriados" e criá-los até o momento de irem para colégios em sistema de internato. Assim, ao fazer tal descrição, o autor anulou a eficiência da instituição familiar no Chile, como se os chilenos desconhecessem seus valores mais rudimentares.

$\mathrm{O}$ autor seguiu descrevendo cenas que presenciou na sociedade chilena, buscando, sempre que possível, desqualificar os principais pilares da sociedade. Os padres foram descritos de forma pejorativa, dentre os quais a palavra "preguiçoso" foi recorrente. Os rituais da Igreja eram para ele artificiais, realizados sem nenhuma reverência verdadeira, tanto pelos padres quanto por muitos dos fiéis. Assim, tanto a família como a religião, que deveriam moldar a moral e as virtudes da nação, para ele eram completamente falhas em cumprir seus objetivos primordiais.

O clima, novamente, é fator presente para justificar a apatia que dominava o país, embora as mulheres não a demonstrassem com a mesma intensidade que os homens este traço:

Sexo frágil é merecidamente falado de uma forma mais branda: [...] "Elas são boas esposas [...] e são fiéis no cuidado de seus filhos, e mais constantes e perseverantes que os homens em tudo que eles se comprometem". Elas possuem algo da indolência que caracteriza os homens, embora não em tão grande grau. ${ }^{38}$

Como já se pode notar, o relato de Gilliss é repleto cheio de contradições em praticamente todos os temas que ele tratou. Nesse excerto, a

\footnotetext{
${ }^{38}$ GILLISS, op. cit., Vol. I p. 162. No original: "The gentler sex is deservedly spoken of in a more lenient manner. "They are good wives,[...] they are faithful in the care of their children, and more constant and persevering than men in all they undertake. They possess something of the indolence characterizing the men, though not to so great a degree."
} 
mulher, que antes deixava seus filhos aos cuidados de uma enfermeira e depois ia para internatos estudar, agora foi descrita como boa cuidadora. Ainda assim, são vistas por Gilliss como menos indolentes que os homens chilenos.

Sobre as profissões e a formação educacional chilena, embora o oficial reconheça que havia no Chile a oferta de formação superior, afirma que esta última se restringia a parte teórica, fato que impedia a formação de bons profissionais que, ao saírem da universidade, acabavam assumindo funções no comércio, no governo ou se tornavam parte do clero e muitos, acabavam retornando ao anterior estado de apatia. Segundo o oficial, essa formação falha trazia como consequência a ausência de engenheiros, químicos, mecânicos ou arquitetos. ${ }^{39}$

Sua explicação, como vimos, é ampla e novamente, rasteira. O autor conectou diversos fatores para, sempre que possível, deteriorar a imagem do homem chileno. Não the ocorreu a falta de oportunidades em uma economia ainda em formação para as profissões graduadas, as quais eram exercidas por estrangeiros trazidos por empreendedores, muitos destes também de fora do país.

Gilliss parece ter desenvolvido ao longo dos anos uma completa falta de afinidade com os homens da elite chilena, como vimos. Tendo como companhia constante os engenheiros norte-americanos que lá cuidavam da construção de estradas de ferro, o cônsul norte-americano e os cientistas oriundos da Europa, o oficial, mergulhado na "zona de contato", sem, no entanto, ter como companhia e acesso às fontes e referências sobre o país os próprios chilenos, não poupou nem mesmo as mais altas classes em seu sentimento de superioridade yankee.

\subsection{4 - O catolicismo e as deformações da sociedade}

${ }^{39}$ Cf. GILLISS, op. cit., Vol. I, p. 162. 
Durante o relato, vimos que muitas são as descrições de chilenos cujas vidas e valores estão pautados pela Igreja Católica. Gilliss não aprovou o que viu. Nas páginas que seguem, veremos que o oficial descreveu uma Igreja centralizadora e influente em todas as esferas da sociedade. Veremos também como Gilliss diminuiu o significado dos rituais católicos assim como destacou as consequências negativas dessa forte influência para o Chile. Da mesma forma que a igreja interferia no governo, ela prejudicava o desenvolvimento da sociedade.

A fim de demonstrar que a população se portava de forma fanática e pouco racional, ao longo do relatório, o oficial procurou descrever ações cotidianas dos fiéis. Gilliss, por exemplo, mencionou que a população se curvava de forma irracional diante dos símbolos da Igreja. Segundo ele, até mesmo o badalar dos sinos eram uma ordem para que todos se ajoelhassem, onde quer que estivessem, em sinal de reverência. Indo adiante, o autor informou que a Igreja proibia o trabalho em muitos dias de festividades religiosas. Um evento em especial o incomodou, posto que se viu impedido de seguir com a edificação do observatório astronômico devido a um feriado religioso:

No meio de erguer os pilares, um dos muitos "dias de festas" observados em países católicos aconteceu, quando as igrejas colocavam a proibição do trabalho por um dia. Para nós, que reconhecidamente não temos dias de descanso, além do Sabbath e o nosso feriado nacional, ou, no máximo, Natal e Sexta-feira Santa incluídos, a ocorrência frequente de períodos interditos, quando muito [trabalho] estava para ser cumprido, era extremamente irritante; e assim o sentimento público começa a ser considerado aqui. No entanto, como o governo apoia as pretensões da Igreja e a sua imposição de multas por violação dos prazos designados, as camadas mais baixas*, por necessidade, obedecem; e enquanto isso continua, e os frades bem alimentados e bem vestidos são 
incentivados à indolência, o Chile nunca pode avançar para a sobrepujança de que tem direito a aspirar. ${ }^{40}$

O autor criticou as imposições da Igreja, tão autoritária quanto o governo chileno, que obrigava a população a participar de suas festividades e as impedia de trabalhar. Mais, a população apática e subserviente não tinha condições de se rebelar contra a Igreja. Indo além, Gilliss culpou também a instituição pela indolência dos chilenos, já que com seus inúmeros feriados, promovia o apreço à inatividade. Por fim, e creio que para o autor, o mais importante, era o fato de que o Estado obedecia às regras de uma instituição "inferior". Para Gilliss, o Estado chileno não era completamente laico. Ao impor multas a quem trabalhasse nos feriados religiosos, a Igreja se sobrepunha ao Estado, que acatava suas ordens. Assim, no Chile, a ordem hierárquica esperada em uma república, estaria invertida. Sobre a forte influência da Igreja no corpo familiar, afirmou:

Também não é apenas em ocasiões públicas, ou respeitando
eventos públicos, que o clero exerce tal poder. Cada família é
controlada por eles, e nenhum marido ou pai tem a autoridade sobre
sua família possuída pelo confessor. Na verdade, não é raro o caso
em que os pontos de vista e opiniões do pai são totalmente
desconsiderados, se em desacordo com as do conselheiro
espiritual. $^{41}$

${ }^{40}$ GILLISS, op.cit. p. 456, Vol. 1. No original: "In the midst of erecting the piers, one of the many "feast days" observed in Catholic countries occurred, when, for the day, their church places a ban on labor. To us, who acknowledge no days of rest but the Sabbath and our national holiday, or at most Christmas and Good Friday included, the frequent recurrence of interdicted periods, when much was to be accom- plished, was extremely annoying; and so public sentiment begins to regard it here. Yet, as government supports the pretensions of the church and its infliction of fines for violation of the appointed times, of necessity the lower orders obey; and while this continues, and the well fed and well clad friars are encouraged to indolence, Chile can never advance to the eminence to which it is entitled to aspire."

*Aqui, convém explicar que o termo "Lower orders" era uma maneira pejorativa de se referir às classes trabalhadoras pertencentes as camadas mais baixas da sociedade. Assim, não se pode traduzir, sob meu entendimento, como "ordens inferiores", tradução literal.

${ }^{41}$ GILLISS, op. cit., Vol. I, p. 163. No original: "Nor is it on public occasions, or respecting public events, that the clergy wield such power. Each household is controlled by them, and no husband or father has the authority over his family possessed by the confessor. In fact, it is not unfrequently the case that the views and opinions of the father are wholly disregarded, if at variance with those of the spiritual adviser." 
No excerto acima, o oficial ampliou os domínios da Igreja, que além de intervir no Estado e no mundo do trabalho e de cuidar para manter seus fiéis em um estado de ignorância, também interferia na vida privada das famílias, a ponto de retirar a autoridade paterna. Vemos assim que Gilliss construiu uma imagem na qual demonstrava que a Igreja reinava no tecido social e nas instituições chilenas.

Curiosamente, Gilliss revelou que não era apenas a Igreja Católica, sob seu ponto de vista, que era extremista. A Igreja Metodista dos Estados Unidos mereceu sua crítica, como podemos ver no excerto abaixo:

\begin{abstract}
A Igreja Católica, por um lado, com a sua porta tão ampla que crianças cambaleantes, anciãos bêbados, e sacerdote dissoluto se alternando sob os despojos da mesa de jogo ou rinha de galos, podem entrar sem o risco de atingir os seus umbrais, pronuncia a condenação da punição eterna a todos os que não se aproveitam disso, e absolutamente recusa o rito da sepultura dentro de seus chamados depositários consagrados de mortalidade. Por outro, o discurso Metodista, com uma torrente de verbalizar os fogos do inferno, as torturas emocionantes do amaldiçoado em meio a chamas de enxofre e de outros recursos brutos para os temores dos tímidos, ousadamente denuncia os seguidores do Papa como idólatras, além dos limites da salvação. Aqui estão os extremos. Uma adere aos ritos, cerimônias, e governo autocrático, talvez essencial antes que a luz da educação seja tão totalmente difundida: o outro é quase destituído de regra fixa, e duma falha democrática na disciplina. Qual é o certo ? $^{42}$
\end{abstract}

Com este último excerto, finalizo as representações sobre a Igreja Católica inferindo que, se esta não agradava ao oficial, certamente outras

\footnotetext{
${ }^{42}$ GILLISS, op. cit., Vol. I, p. 170-1. No original: "The Catholic church on one hand, with its door so broad that tottering children, inebriate greybeards, and dissolute priest staggering under the spoils of the gambling-table or cock-pit, may enter without the risk of striking its side-posts, pronounces the doom of everlasting punishment on all who do not avail themselves of it, and absolutely refuses them the rite of sepulture within its so-called consecrated depositories of mortality. On the other, the ranting Methodist, with a torrent of verbi- age breathing of the fires of hell, the thrilling tortures of the accursed amid flames of sulphur, and other gross appeals to the fears of the timid, boldly denounces the followers of the Pope as idolaters, beyond the pale of salvation. Here are the extremes. One adheres to the rites, ceremonies, and autocratic government, perhaps essential ere the light of education was so generally diffused: the other is almost destitute of fixed rule, and to a fault democratic in discipline. Which is right?"
} 
igrejas protestantes também mereciam suas críticas. Ambas para ele possuíam problemas com a rigidez de dogmas e intolerância para com outras religiões. Inserido no mundo da ciência, Gilliss entende que as religiões careciam de uma reflexão sobre suas condutas, posto que a seu ver, a humanidade havia evoluído e já não precisava agir sob o comando absoluto da Igreja. Esse modo centralizador da religião em manter os fiéis impedia a sua evolução e o livre pensar, traduzindo um modo de ser e de agir que era o oposto ao modus operandi de um cientista. Gilliss certamente não era muito religioso. Embora o oficial faça uma comparação para criticar todo o tipo de fanatismo e intolerância e deixe a pergunta sobre qual dogma estaria certo, ele não ofereceu respostas. Quer-se dizer também que no correr da pesquisa não foi possível verificar a religião do viajante. Mas as inúmeras críticas que teceu sobre a Igreja Católica permite afirmar que esta, em sua visão, era a mais condenável, posto que interferia de forma negativa, muitas vezes, no governo, na família e por fim, era incompetente em sua função de moralizar e incutir valores cristãos na população chilena.

\section{4 - Os interesses geopolíticos e comerciais}

O primeiro volume do relatório oficial da viagem, inicia-se com o tópico "Geografia descritiva". É principalmente nessa sessão que observamos o cuidado em oferecer informações orientadas a identificar portos ou lugares propícios para suas construções, principais estradas, riquezas minerais e potencial do solo para agricultura, além de investimentos que estavam sendo feitos no país por capitalistas estrangeiros.

$\mathrm{O}$ autor, antes de iniciar qualquer descrição, ofereceu um mapa da cidade, oriundo da Academia Militar de Santiago. Nele, estão numerados todos os principais pontos de interesse, tais como o Palácio presidencial, consulado, igrejas, monastérios, entre outros estabelecimentos. 
Gilliss criou um padrão para organizar sua escrita sobre cada cidade: longas descrições geográficas e topográficas, seguidas de uma breve história da cidade e do que pode ser encontrado nela, de igrejas e hospitais a mercados, teatros e lazer em geral. Para cada lugar visitado, Gilliss informou sobre as manufaturas locais, riquezas exploradas ou de potencial para exploração e possibilidades de investimentos em linhas férreas. Ao final, em geral apresentou censos e estatísticas sobre mortalidade e natalidade, doenças, administração e gastos públicos, assim como informações sobre a população de cada cidade, as "raças e classes" ali encontradas e qualquer informação que julgou útil ou que tenha lhe chamado à atenção. Suas escolhas demonstram o interesse em dominar saberes locais sobre uma região ainda pouco conhecida nos Estados Unidos.

Muito do que Gilliss escreveu sobre este tema, como já dito, foi extraído de viajantes, de contatos com norte-americanos que lá viviam e com uns poucos membros das elites locais, de empreendedores e de censos locais. Nessa parte descritiva, o autor se valeu de muitas referências, tais como Darwin, Charles Wilkes e também de um cientista bielorrusso, residente no Chile desde 1838 e naturalizado chileno em 1848, o geólogo Ignacio Domeyko. Isso se deve ao fato de que o autor não percorreu todo o Chile. Era necessário valer-se para a elaboração de suas descrições tanto de ajuda de leituras preexistentes sobre o tema como do auxílio de especialistas locais e foi exatamente o que Gilliss fez:

Prof. Domeyko é o único viajante científico conhecido por mim, que penetrou até a crista da Cordilheira dos Andes por passagem diferente. Um relatório geológico de sua jornada para "Come Cavallo", relata a passagem na província de Atacama, e "Laguna", na província de Coquimbo, que pode ser encontrada nos Annales des Mines, vol. IX, 1846. Estas viagens, e outras, a diferentes altitudes na cadeia andina, sul de Santiago — feita posteriormente 
- foram temas frequentes de conversação; e as informações a respeito delas foram totalmente obtidas a partir dele [Domeyko]. ${ }^{43}$

Nota-se aqui, que Gilliss fez questão de informar que muitas das informações foram recolhidas através de escritos e de conversas com Ignacio Domeyko, um geólogo local extremamente respeitado. Curiosamente, como veremos mais adiante, esse mesmo cientista irá refutar seus escritos sobre o Chile. Vejamos agora como e o que Gilliss escolheu relatar sobre o país.

Sobre as principais cidades, escolho uma crítica do autor, comparando a Concepción com Santiago, na qual ele considera a primeira, devido à localização, que inclui um bom porto, clima e segurança como a mais adequada para se tornar a capital do país. Veremos que ele culpou os políticos e a Igreja como os principais opositores com relação a este aspecto.

[...] Muitos acreditavam que essas grandes vantagens locais iriam construir Concepción à custa de Santiago, ou, na verdade, que a primeira deveria inevitavelmente se tornar a capital da nova república. E tal teria sido o caso com uma população comercial e empreendedora; mas este resultado não é mais possível; pois demasiada influência, sacerdotal bem como pecuniária, tem-se concentrado em Santiago de modo a nunca permitir tal realização. Se não tivessem os índios lhes cercados por todos os lados, e nenhum acordo com eles estava seguro além das cercanias da cidade, agricultores pobres como era o povo de Concepción, teria oferecido tais quantidades de produtos para exportação como teria criado uma cidade muito mais extensa do que a que agora existe. Índios, terremotos e a negligência de seus interesses por parte do governo central, têm impedido a sua riqueza e recursos de serem totalmente desenvolvidos. Os primeiros, como todos os da sua origem em outros lugares, estão a desaparecer sob os vícios e doenças semeadas pela raça branca .... ${ }^{44}$

\footnotetext{
${ }^{43}$ GILLISS, op. cit., Vol. I, p. 7. No original: "Prof. Domeyko is the only scientific traveller known to me who has penetrated to the crest of the Andes by any other of the passes. A geological account of his journey to "Come Cavallo" (literally eat horse) pass, in the province of Atacama, and "Laguna" (lake) pass, in the province of Coquimbo, may be found in the Annales des Mines, vol. ix, 1846. These journeys, and others, to different elevations in the Andean chain, south of Santiago-, made subsequently, were frequent subjects of conversation; and the information respecting them has been wholly obtained from him."

${ }^{44}$ GILLISS, op. cit., Vol. I, p. 29-30. No original: [...] "many believed that these great local advantages would build up Concepcion, at the expense of Santiago, or, in fact, that the former must inevitably become
} 
Gilliss acreditava poder interferir nas escolhas locais, ele julgava saber melhor que os chilenos o local ideal para a sua capital. A análise do autor demonstra que apesar das vantagens indicadas, o medo de ataques indígenas, que a seu ver, já era muito pequeno, mas principalmente os interesses políticos e eclesiásticos, impediram a devida exploração do local. Aqui, notase que para além da crítica, Gilliss procurou demonstrar a capacidade do país em importações e exportações e buscou informar aos leitores sobre possíveis investimentos naquela região. É como se tentasse alertar aos estrangeiros sobre um local com alta capacidade de lucratividade e que servia como ponto de abastecimento para a Califórnia e de navios baleeiros norte-americanos.

Gilliss, ao relatar sobre as fontes de riqueza na região de Copiapó, rica em minérios, alertou aos empreendedores sobre as necessidades locais e demonstrou como investidores estrangeiros estavam modificando a situação das coisas no Chile:

[...] por falta de combustível para reduzir os minérios, e por causa da despesa de transporte entre as regiões carentes de água ou pasto para seus animais, eles são impedidos de tirar o máximo dessa fonte de riqueza. Apesar desses obstáculos, no entanto, a prosperidade da província tem feito avanço rápido ultimamente e o impulso dado ao seu comércio com o sucesso da ferrovia entre Caldera e Copiapó, já despertou seus cidadãos para outros empreendimentos. [...] Durante 1850, foram enviados de Atacama para portos estrangeiros produtos no valor de $\$ 1.443 .642$, e para portos nacionais no valor de $\$ 5.175 .231$; quase toda prata e cobre encaminhados para Valparaiso apenas em obediência às leis do comércio, foram imediatamente enviados para o exterior. Toda a prata vai para a Inglaterra. No mesmo período, o valor das

the capital of the new republic. And such would have been the case with an enterprising commercial population; but this result is no longer possible; too much influence, priestly as well as pecuniary, has been concentrated at Santiago, ever to permit such translation. Had it not been that the Indians hemmed them in on all sides, and no settlement was safe from their raids much beyond musket-range of the town, poor agriculturists as they were, the people of Concepcion would have offered such amounts of produce for export as would have created a far more extensive city than now exists. Indians, earthquakes, and neglect of its interests by the Central government, have prevented its wealth and resources from being fully developed. The former, like all of their origin elsewhere, are disappearing under the vices and diseases sown by the white race..." 
importações foi de $\$ 2.457 .501$; desses bens estrangeiros, os que não chegaram diretamente foram estimados em $\$ 804.876$, deixando um saldo em favor da província no montante de $\$ 2.717 .730{ }^{45}$

A estrada de ferro a qual o autor se refere foi obra do norte-americano William Wheelwright. Notamos que Gilliss informou os lucros obtidos a partir da extração de minérios e metais e do comércio crescente nas regiões em que chegavam essas estradas. Até aquele momento, os grandes investidores na região eram ingleses em parceria com Wheelwright, que foi o responsável pela construção de estradas de ferro, linhas de vapor entre Chile e Panamá, entre outros investimentos. A meu ver, o autor também buscou demonstrar aos empreendedores norte-americanos que no Chile, poderiam investir com grande segurança de retorno financeiro, visando à Califórnia e competindo com os ingleses. Como vimos, o autor foi zeloso em demonstrar os lucros obtidos na região, fato que se repetiu muitas vezes ao longo de seu relatório. Ele procurou também indicar os lugares ricos em minas de cobre e prata, apropriados, portanto, para a construção de novas estradas. Além disso, alerta para a necessidade de se construir barragens na região de Coquimbo, a fim de favorecer a irrigação das fazendas locais. Se, para a produção de minério foram oferecidos números vantajosos, o mesmo ocorreu com seu relatório de agricultura:

Tomando o ano de 1850, quando as colheitas eram regulares com um padrão, as provisões foram trazidas por mar no valor de $\$ 433.503$ e das províncias argentinas no valor de $\$ 22.840$, das

\footnotetext{
${ }^{45}$ Gilliss, op. cit., Vol. I, p. 45. No original: [...] "But from want of fuel to reduce the ores, and because of the expense of transportation across regions destitute of water or grass for their animals, they are prevented from deriving full advantage from even this source of wealth. Notwithstanding these obstacles, however, the prosperity of the province has latterly made rapid advancement, and the impetus given its trade by the success of the railroad between Caldera and Copiapo has already roused its citizens to other enterprises.[...] During 1850 there were shipped from Atacama to foreign ports products to the value of $\$ 1,443,642$, and to domestic ports to the value of \$5,175,231; almost all of which silver and copper forwarded to Valparaiso only in obedience to the laws of trade, was immediately sent abroad. The silver uniformly goes to England. In the same period the value of the imports was \$2,457,501; of which the foreign goods naturalized for there were no direct arrivals were estimated at $\$ 804,876$, leaving a balance in favor of the province amounting to $\$ 2,717,730 . "$
} 
quais, três quartos desse último montante foi para o gado preto. No mesmo ano, provisões domésticas similares foram exportadas pelo valor de $\$ 47.872 .^{46}$

Em Maypu, local onde as técnicas de irrigação e adubagem do solo já estavam sendo empregadas, o autor procurou demonstrar os resultados e a eficácia de tal empreendimento e técnica.

[...] desde que seus proprietários começaram a inundá-lo com água do Maypu, os depósitos anuais de lodo mineral tornaram-no valioso, e agora não há praticamente um acre, no qual a água pode ser introduzida, que não é altamente produtivo. [...] não há praticamente um solo melhor no mundo; e a sua produtividade, mesmo sob o sistema infeliz de cultivo praticado, é maior do que a da maioria das melhores terras nos Estados Unidos. [...] Mas implementos de lavoura não são bem vindos pelos peões chilenos; aqueles comprados por empreendedores agricultores foram jogados de lado depois de um único ensaio, e são somente utilizados quando o mestre está observando. ${ }^{47}$

É bastante evidente que Gilliss ao mesmo tempo em que informou sobre a riqueza do solo e as possibilidades de investimentos locais, denunciou a falta de capacidade empreendedora ou de administração dos fazendeiros. Assim, ao mesmo tempo em que mapeou a riqueza local, preenchendo o relatório oficial com tais informações, abriu os olhos de empreendedores estrangeiros para os ricos solos, as estradas a serem construídas e a falta de mão de obra eficiente entre os chilenos que só trabalhavam direito, segundo Gilliss, sob as vistas do patrão. $\mathrm{O}$ autor chega ao ponto de dizer que nem em

\footnotetext{
${ }^{46}$ GILLISS, op. cit., Vol. I, p. 46 . No original: "Taking the year 1850, when the crops were a fair average, as a standard, provisions were brought by sea to the value of $\$ 433,503$, and from the Argentine provinces to the value of \$22,840, of which three fourths of the latter sum was for black cattle. In the same year, similar domestic provisions were exported to the value of $\$ 47,872 . "$

${ }^{47}$ GILLISS, op. cit., Vol. I, p. 466. No original: [...] "since its proprietors have begun to flood it with water from the Maypu, the annual deposits of mineral silt have rendered it valuable, and now there is scarcely an acre, on which water can be introduced, that is not highly productive. [...] Yet there is scarcely a better soil in the world; and its productiveness, even under the wretched system of cultivation practised, is greater than that of the majority of the best lands in the United States. [...] But improved implements of husbandry meet with no favor among Chilean peons; those bought by enterprising farmers have been thrown aside after a single trial, and are again resorted to only when the master stands by to watch them."
} 
seu país havia terra mais fértil, fato que se tornava insignificante na medida em que os lavradores não se esmeravam em cuidar da terra da forma adequada. Assim, mesmo onde o autor enxergou riqueza e prosperidade, imediatamente ele desqualificou tais aspectos devido ao homem chileno, incapaz de tirar de seu território as vantagens que ele oferecia.

Sobre os investimentos feitos no Chile, o norte-americano William Wheelwright foi companhia de Gilliss pelo interior do Chile e um de seus principais informantes. Muito respeitado no Chile por sua contribuição aos avanços do país, Gilliss relatou um desses momentos em que recebeu uma homenagem pública do governo chileno.

Ao fim de cerca de uma hora, os nomes das pessoas com mais direito à gratidão do Chile, sejam pelos esforços para efetuar o avanço moral ou material, comércio, agricultura, ou a artes mecânicas, foram anunciados publicamente. Entre tais, estava nosso conterrâneo William Wheelwright, a quem foi presenteada uma medalha de ouro, tendo de um lado o brasão de armas da República, e no anverso um navio a vapor, com a inscrição: "O Governo do Chile para William Wheelwright: um sinal de gratidão para a introdução da navegação a vapor e ferrovias". E ninguém além dele merecia tal reconhecimento público. ${ }^{48}$

Vemos aqui, o já conhecido orgulho norte-americano, já que este empreendedor de fato foi o responsável por inúmeras obras de benfeitoria no Chile. Da criação de linhas a vapor e estradas de ferro, a aquedutos e até mesmo do primeiro corpo de bombeiros do país, Wheelwright passou grande parte de sua vida morando e investindo no Chile. Suas obras mereceram inclusive um livro, de título "The Life and Industrial Labors of William Wheelwright in South America" escrito por Juan Bautista Alberdi. Nele,

\footnotetext{
${ }^{48}$ Gilliss, op. cit., Vol. I, p.487. No original: "At the end of about an hour the names of the individuals most entitled to the gratitude of Chile, whether for efforts to effect moral or physical advancement, commerce, agriculture, or the mechanic arts, were publicly announced. Among the number was our countryman, William Wheelwright, Esq., to whom was presented a gold medal, bearing on one side the coat of arms of the republic, and on the obverse a steamship, with the inscription, "The Government of Chile to William Wheelwright: a token of gratitude for the introduction of steam navigation and railroads." And no man more richly deserved so public an acknowledgment."
} 
Alberdi elogiou a capacidade empreendedora do autor e reconheceu suas contribuições, embora tenha feito questão de frisar que a honra dada à Wheelwright não se estendia a todos os norte-americanos. ${ }^{49}$

Por várias ocasiões, Gilliss condicionou o crescimento do Chile ao trabalho de empreendedores ou de imigrantes "enérgicos". Em visita a Cachapual, acompanhando um engenheiro norte-americano que supervisionava a construção de uma estrada de ferro, o autor denegriu os chilenos e apontou que os benefícios das estradas de ferro junto da chegada de imigrantes, poderiam ajudar a desenvolver o país:

Enquanto eu observava, eu poderia somente esperar que com o trovão da locomotiva através deste vale nobre, viria a existir uma raça mais imbuída de empreendimento e energia, de um povo mais competente para o desenvolvimento de sua vasta e incomparável riqueza agrícola. $^{50}$

Certamente informações como essas atraiam a intenção de investidores e imigrantes. No Chile da primeira metade do século XIX, muitos europeus, especialmente da região da Prússia, migraram para lá, fato que interessava ao governo chileno. Ademais, como vimos, os investimentos em estradas de ferro e linhas de trem e mesmo de navios a vapor foram empreendimentos feitos por estrangeiros ou, como caso emblemático, pelo já citado empreendedor norte-americano Wheelwrigth, em parceria econômica com os ingleses.

Aqui, é importante lembrar que os Estados Unidos ainda eram um país consolidando o seu Estado nacional e focado em desenvolver e fortalecer o seu próprio domínio territorial, que acabara de se ampliar com suas recentes anexações. A verdade é que a cultura imperial pode ser encontrada desde o

\footnotetext{
${ }^{49}$ Cf: ALBERDI, Juan. La vida y los trabajos industriales de William Wheelwright en la América del Sud. Paris: Librerie de Garnier Hermanos, 1876. Uma versão em Inglês também foi impressa, no ano de 1877.

${ }^{50}$ Gilliss, op. cit., Vol. I, p.474. No original: As I looked upon it, I could but hope that with the thunder of the locomotive across this noble valley, there will come into existence a race more imbued with enterprise and energy a people more competent to the development of its vast and incomparable agricultural wealth.
} 
início da fundação do Estado nacional e reverberava de forma contundente no relatório de viagem de Gilliss.

No entanto, a própria guerra contra o México trouxe custos enormes durante a batalha e investimentos para consolidar as anexações, fato que obrigava o país a voltar sua atenção para seu próprio território, a fim de manter a já iniciada superioridade política e econômica com relação aos países sul-americanos e demarcar seu poder diante das potências europeias. Mas, suas inserções nas expedições em busca de conhecimento geopolítico bem como seu esforço em firmar novos acordos comerciais indicam a preocupação em continuar demarcando seu espaço entre as nações do mundo.

\section{5 - A expedição astronômica e seu papel civilizador na América do Sul}

O autor, ao narrar o início do assentamento do observatório em Santa Lucia, procurou passar a imagem - já conhecida pelos historiadores da América - dos norte-americanos que levavam o progresso para outras nações. Os excertos abaixo descrevem bem esse lugar em que Gilliss se colocou. Primeiro, nos contou que o governo e a Universidade do Chile haviam pedido que estagiários e um professor fossem admitidos no Observatório a fim de aprofundarem o conhecimento sobre Astronomia, pedido prontamente atendido por eles que se mostraram muito solícitos, como o oficial descreveu:

Fervorosamente na esperança de aumentar o interesse em nossas atividades, a proposição foi cordialmente consentida [...] Nossos livros foram imediatamente colocados à sua disposição; explicações foram dadas a eles em todos os momentos, e as oportunidades tornaram possível que eles se familiarizassem com o círculo meridiano, e um [telescópio] equatorial menor foi emprestado para seu uso exclusivo. ${ }^{51}$

\footnotetext{
${ }^{51}$ GILLISS, op. cit., Vol. III, p. XXXIII. No original: "Earnestly hoping to increase the interest in our pursuits, the proposition was cordially assented to [...] Our books were at once placed at their disposal; explanations were given them at all times; opportunities afforded them to become familiar with the meridian circle, and the smaller equatorial was loaned for their exclusive use. "[...]
} 
Gilliss prosseguiu, agora mencionando sobre o papel dos oficiais da expedição e do observatório para com a população chilena:

[...] Não era apenas o governo que estava interessado que o conhecimento astronômico deveria ser cultivado no Chile. Quando o primeiro [telescópio] equatorial foi montado, noite após noite, dezenas de pessoas subiram a colina para ver a maravilhosa "maquina", como eles chamam o instrumento lindamente equilibrado, mas aparentemente complexo; [...] Todos os que vieram foram admitidos - homens, mulheres e crianças, ricos ou pobres; mesmo o sentinela que estava com o sabre ao lado da porta não foi desprezado, e cada um por sua vez, foi embora satisfeito, o pobre respeitosamente esperando até que seus concidadãos mais afortunados dessem lugar dentro do edifício. [...] Tínhamos sido informados por conhecidos de que as classes mais baixas que vivem no e próximo ao sistema operacional da base do morro eram homens de tendências viciosas, que seria perigoso para atender desarmado a uma hora tardia da noite, mas a seu crédito seja dito, nós nunca fomos molestados[...] Não pode a nossa civilidade, quando chegaram e quiseram ver o telescópio e os objetos curiosos exibidos, ter assegurado sua boa vontade? $?^{52}$

A verdade é que se o Chile havia cedido na construção do Observatório Astronômico, obviamente havia interesse por parte do governo chileno. Por outro lado, sem a oferta chilena, o projeto de Gilliss não poderia ser levado a cabo. Talvez isso explique as contradições postas no relato de viagem: ora enaltece a região e a sociedade, ora as desqualifica completamente.

Assim, concluo que o Chile não pode ser compreendido apenas como um local que serviu aos propósitos norte-americanos, mas sim, como um país

\footnotetext{
${ }^{52}$ GILLISS, op. cit., Vol.III, p. XXXIII-XXXIV. No original: "Nor was it the government only who were interested that astronomical knowledge should be cultivated in Chile. When the equatorial was first mounted, nigth after night, scores of persons ascended the hill to see the wonderful "maquina", as they called the beautifully equipoised but apparently complex instrument; [...] All who came were admitted - men, women and children, rich or poor; even the sentinel who stood with sabre beside the door was not slighted; and each in turn went away gratified, the poor deferentially waiting until their more fortunate countrymen gave place within the building. [...]We had been told hy acquaintances that the lower classes living on and near the base of the hill were men of vicious propensities, whom it would bo hazardous to meet unarmed at a late hour of the night; but, to their credit be it said, we were never molested. [...]May not our civility, when they came desiring to see the telescope and the curious objects it displayed, have secured their good will?"
} 
que esperava também se beneficiar do empreendimento da expedição. Ademais, a troca me parece um tanto justa, considerando que os norteamericanos estavam utilizando o território chileno para produzir suas pesquisas, com o auxílio, diga-se de passagem, de construtores, guardas e por fim, aprendizes de astronomia chilenos, que colaboraram ativamente com as observações, como admitiu o próprio Gilliss.

Como vimos, o autor também contou que abriu as portas de seu observatório aos chilenos comuns, independente de sua classe social, embora, como ele afirmou, a elite local tivesse prioridade de entrada. Em sua visão, estavam fazendo um grande bem àquelas pessoas e àquele país, pois levavam, como principio básico do Destino Manifesto, o progresso e a civilidade a um país sul-americano, através do conhecimento. Representantes que eram dessa suposta civilidade, a seu ver o impacto foi tão profundo que nem mesmo as pessoas supostamente perigosas os atacaram nos anos em que lá residiram.

\section{6 - Ignacio Domeyko critica o relatório de viagem de Gilliss}

Após a impressão do primeiro volume do relatório, uma crítica interessante foi produzida a partir do Chile, pelo geólogo Ignacio Domeyko, o mesmo que Gilliss afirmou ter trocado informações para escrever sobre a geografia local. Este acabou escrevendo um artigo no mesmo ano em que o relatório foi publicado, refutando muitas das informações contidas no relatório de Gillliss sobre a geografia descritiva feita por ele, e até mesmo sobre seus relatórios sobre terremotos e as impressões de Gilliss sobre a apatia chilena e sua relação com o clima do país.

Domeyko, um europeu vindo da Bielorrússia, residente e naturalizado chileno, escreveu um artigo em um periódico chileno, intitulado Revista de Ciências i Letras, no qual desqualificou o relatório de viagem de Gilliss, ao mesmo tempo em que qualificou o local que escolheu viver, incluindo sua população. Usando de argumentação científica, Domeyko usou de muita 
didática e demonstração de conhecimento para tentar comprovar que o que Gilliss escreveu era impreciso por diversas razões: falta de conhecimento geográfico, releituras equivocadas ou mal interpretadas de outros relatos e falta de organização espacial para descrever as cidades. Domeyko, em nome da racionalidade científica, questionava o relato de Gilliss. Ademais, é clara a intenção do autor de desconstruir a imagem do Chile como lugar inóspito e degenerador. Domeyko foi, curiosamente, uma das principais fontes de Gilliss nas descrições geográficas, das águas, das minas de ferro e cobre e até mesmo dos índios Araucanos. Vejamos como Domeyko construiu sua análise.

Antes de iniciar suas críticas específicas nesse artigo, o autor apresentou o trabalho de Gilliss, e fez uma crítica sagaz e sarcástica sobre o olhar e a escrita comum aos viajantes:

Deixando de lado a parte da viagem, no qual o autor como a maioria dos escritores de viagens pitorescas que abundam na literatura moderna, fala de inúmeros acidentes pessoais, que pintam o caráter do viajante e não o país no qual ele viajou, vou me concentrar apenas na parte científica, séria, para ver com quanto este primeiro volume, obra de uma expedição científica de três anos, tem contribuído para o alargamento de conhecimentos positivos geográficos que tínhamos do Chile antes da chegada do autor às nossas costas $?^{53}$

$\mathrm{O}$ excerto acima, primeiramente desqualifica as representações "pitorescas", próprias de um viajante, nas quais suas impressões dizem mais de si próprio do que do local visitado. Essa primeira afirmação de Domeyko chama muito a atenção, pois demonstra aos historiadores que trabalham com

\footnotetext{
${ }^{53}$ Revista de Ciencias $i$ Letras. "Estudios jeográficos sobre Chile, con ocasion da la publicacion del primer tomo de la obra 'U.S. Naval Astronomical Expedition to the Southern hemisfere during the years 1849-5051-52.' Por J.M. Gilliss." Vol. 4, 1857. DOMEYKO, Ignacio. No original: "Dejando a un lado la parte del viaje, en que el autor como los mas autores de viajes pintorezcos en que tanto abundan las literaturas modernas, habla de infinidad de accidentes personales, que pintam el carácter del viagero i no el pais en que ha viajado, me fijaré solamente en la parte séria, cientifica, para ver con cuánto este primer volúmen, obra de una espedicion cientifica de tres años, ha contribuido al ensanche de los conocimientos positivos jeográficos, que teniamos de Chile antes de la llegada del autor a nuestra costa?"
} 
relatos de viagem que o mesmo tipo de percepção que temos hoje, quando conveniente, também ocorria no século XIX.

Na sequência, anuncia que irá examinar o que realmente foi produzido de novo pelo autor sobre a parte científica e "séria" da viagem. Essa última afirmativa já desconsidera as representações sobre os aspectos sociais feitas por Gilliss.

Sobre as descrições sobre o país, Domeyko afirmou que o oficial, devido à natureza cientifica astronômica de sua viagem, não podia separar-se por muito tempo de seu observatório e por isso, poucas vezes saiu em incursões pelo país:

A expedição norte-americana, como acabo de dizer, tinha como principal objetivo estudar mais o nosso charmoso céu do que a terra, e por isso, forçou seu comandante a fazer uma longa série de observações que não permitiam à ele deixar seu observatório, e [este] não conseguiu fazer uma única viagem exploratória para o interior do país, que lhe daria a oportunidade de alargar o círculo de conhecimento que a ciência possuía antes de sua chegada no Chile, no que se refere a estudos geográficos desta grande porção do mundo. As únicas saídas que o Sr. Gilliss pode fazer durante seus três anos de permanência no Chile, foram uma curta caminhada do Lago Aculeo, localizado a uma curta distância da capital, outra à Talca e, de lá, ao porto de Constitucion, pelo caminho melhor povoado e melhor conhecido do Chile, e um terceiro, não menos rápido, de Caldera à Chañarcillo, através de um vale cuja inspeção, como a de qualquer outro lugar no mundo por onde passam as estradas de ferro, pouca coisa nova pode esperar a geografia e a física do globo terrestre. ${ }^{54}$

\footnotetext{
${ }^{54}$ Revista de Ciencias i Letras, op.cit., p.634. No original: "La espedicion norte-americana, como acabo de decir, ha tenido por objeto mas bien el estudio de nuestro hemoso ciclo que de la tierra, i poe esto, obligado su jefe a hacer una larga serie de observaciones que no le permitieron separarse de su observatorio, no ha podido hacer un solo viaje de esploraion en el interior del pais, que le diera la ocasion de estender el círculo de los conocimientos que la ciencia poseia ántes de su llegada a Chile, en lo relativo a estudios jeográficos de esta gran parte del mundo. Las únicas salidas que el señor Gilliss pudo hacer durante sus tres años de permanencia en Chile, han sido un corto paseo a la laguna de Aculeo situada a poca distancia de la capital, otro a Talca i de allí al puerto de Constitucion por el camino mejor poblado i mejor conocido de Chile, e um tercero, no menos precipitado de la Caldera a Chañarcillo por un valle de cuya inspeccion como la de cualquier otro lugar del mundo por donde pasan los caminos de hierro, poca cosa nova pueden esperar la jeografia i la física del globo terrestre."
} 
Domeyko ao utilizar o pronome possessivo "nosso", indica a identidade que escolhera: chilena. Novamente, o geólogo colocou em dúvida o relatório geográfico produzido por Gilliss, indicando que o principal objetivo da expedição era astronômico e que o autor não viajara pelo Chile. Sabemos que a viagem e a observação in locu não é sinônimo de veracidade em relatos de viagem. Mas não é isso que importa aqui, o que merece destaque é que o relatório de viagem de Gilliss foi refutado e a partir de argumentos sólidos já no período, por um cientista de renome. Como comparação, Domeyko citou mais adiante viajantes naturalistas, que se empenharam em conhecer a geografia chilena, viajando efetivamente pelo território.

Buscando contrapor as imagens negativas construídas por Gilliss sobre o país, o geólogo procura descrevê-lo de forma paradisíaca:

Chile, país de belas montanhas e cordilheiras, de selvas virgens e áridos desertos, de todos os climas e regiões imagináveis, desde os gelos perpétuos até os climas que poderiam envidar os habitantes das terras mais amenas até as mais ardentes dos trópicos: Chile atrairá sempre com irresistíveis encantos e compensará sempre com novos presentes para a ciência a todos os viajantes naturalistas, que, longe dos caminhos reais, das casas de hospedagem e de pousadas farão como Darwing, Peppig, Gay, Bertero, Pissis ou Phillippi, a caminhar por onde quiser pela imensidão de objetos que a natureza com tanta profusão e variedade derrama em uma área de 150.000 milhas quadradas. ${ }^{55}$

Diferentemente do que Gilliss retratou em seu relatório, Domeyko buscou demonstrar que o Chile era um lugar aprazível de se viver. Devo aqui lembrar que na primeira metade do século XIX houve uma campanha

\footnotetext{
${ }^{55}$ Revista de Ciencias i Letras, op.cit., p.634. No original: "Chile, pais de hermosas montañas i cordilleras, de selvas virjenes i áridos desiertos, de todos los climas i regiones imajinables desde los hielos perpétuos hasta los climas que podrian envidar los habitantes de las tierras mas amenas i mas ardientes de los trópicos: Chile atraerá siempre con irresistibles encantos $i$ compensará siempre con nuevos regalos para la ciencia a todo viajero naturalista, que, apartándose de los caminos reales $i$ de las hospitalarias casas $i$ posadas, vaya como Darwing, Peppig, Gay, Bertero, Pissis o Phillippi, a campear por do quiera en esa inmensidad de objetos que la naturaleza con tanta profusion i variedad derrama en una superficie de 150.000 millas cuadradas."
} 
governamental em busca de colonos europeus, especialmente os da Alemanha. Assim, acredito que o artigo continha intenções políticas que buscavam desfazer as imagens negativas construídas por Gilliss.

Ao listar as viagens do oficial, o autor demonstrou ter acompanhado seus passos. De fato, esteve com ele em pelo menos uma dessas viagens, mas tal fato é omitido por Domeyko. Gilliss, por sua vez, não deixou de citá-lo inúmeras vezes, inclusive quando juntos viajaram.

Muitas são as correções feitas por Domeyko sobre a descrição geográfica do Chile. Não é minha intenção aqui comentar cada uma delas, mas sim, oferecer ao leitor ao menos uma ideia da forma como o geólogo desconstruiu as descrições de Gilliss. Escolho, portanto, um excerto sobre a descrição dos Andes, na qual Domeyko refuta por completo as descrições do oficial:

Independentemente de leviandade, falta de método e com a confusão que o autor descreve os Andes, gostaria de saber de onde o Sr. Gilliss tirou que os Andes em frente a Talca, possuem cinco cordões [montanhosos]? O autor não se aproximou deles, e ignorou que algum viajante que visitou estas colinas tenha dito tal coisa. [...] Teria sido mais útil e mais fácil para o autor, se em vez de falar sobre esses cordões [montanhosos] que nunca viu, nos tivesse dado em lugar um tratado da configuração exterior geral do Chile, uma definição geográfica e exata do que ele chama Grande Vale Chileno (gran Chilean valley), pois este vale foi visto pelo autor e merecia uma descrição cuidadosa em uma obra de tão grande porte sobre o Chile. ${ }^{56}$

Acima, claramente, Domeyko afirmou que Gilliss descreveu erroneamente partes do Chile as quais nunca viu e deixou de fazer análises de

\footnotetext{
${ }^{56}$ Revista de Ciencias i Letras, op.cit., p.640. No original: "Prescindiendo de la lijereza, falta de método i de la confusion com que el autor describe los Andes, quisera saber, de dónde ha sacado el señor Gilliss que los Andes enfrente de Talca, constam de cinco cordones? El autor no se acercó a ellos, e ignoro que algun viajero de los que han visitado estos cerros haya dicho semejante cosa.[...] Habria sido mas útil i mas fácil para el autor, si en lugar de hablar de aquellos cordones que nunca ha visto, nos hubiese dado en este lugar, tratando de la configuracion exterior jeneral de Chile, unadefinicion jeográfica i exacta de lo que él llama Gran Valle Chileno(great Chilean valley), pues este valle lo ha visto el autor i merecia una descripcion prolija en una obra tan abultada sobre Chile."
} 
partes que efetivamente observou. O geólogo seguiu corrigindo muitas descrições geográficas e localizações feitas pelo autor e fez questão de mencionar que quase tudo o que foi escrito por Gilliss sobre o Chile, foi lido em outros relatos, em censos ou em jornais e revistas chilenas. Assim, afirma que o trabalho de Gilliss representava o árduo trabalho de um compilador.

Embora haja uma aparente coerência nas correções feitas por Domeyko, não podemos deixar de inferir que ele escreveu o artigo motivado por diversas razões, quais sejam, as políticas e geopolíticas, na medida em que buscou valorizar o Chile, país que adotara e que reconhecia o seu trabalho, e incutir dúvidas sobre quase tudo o que estava descrito no relatório, assim como sua defesa com relação aos chilenos e ao clima do país e as motivações pessoais, já que Domeyko era considerado uma grande autoridade no Chile no que se refere aos estudos geográficos e geológicos.

Assim, apesar da coerência em suas críticas, é preciso relativizar muito do que foi dito. Quando pensamos na riqueza contida nas minas de prata e nas ainda inexploradas minas de cobre, por exemplo, não é difícil imaginar que a oferta de detalhes oferecidos por Gilliss em seu relatório de muitas maneiras preocupou as autoridades chilenas.

\subsection{1 - Ignacio Domeyko refuta a ideia de "apatia chilena"}

Embora o geólogo no início do artigo afirme que não iria ater-se às questões "não científicas", Domeyko não se conteve e refutou as considerações que associavam o clima do Chile a uma população que acabava por caracterizar-se como apática. Domeyko relatou claramente o que Gilliss afirmou em seu relatório e fez inclusive citações - as mesmas feitas por mim ao discutir o clima do Chile neste capítulo - sobre os prognósticos do autor referente ao clima. Após as citações de Gilliss, teceu os seguintes comentários: 
Começa por dizer que o clima do Chile é muito agradável devido a sua uniformidade e suavidade em qualquer estação do ano. $\mathrm{O}$ mesmo autor, em outra parte de sua obra, se entusiasma com a beleza de nosso céu. Mas então ele faz uma advertência muito singular, relacionada à impressão que tem exercido sobre ele e seus companheiros esta temperatura encantadora. Duvida que esta suavidade e uniformidade do clima sejam o melhor para o progresso da humanidade. ${ }^{57}$

\section{Após citar outro trecho de Gilliss sobre os efeitos do clima, Domeyko} então questionou a lógica de tais afirmações:

Não sei a quais raças alude ao Sr. Gilliss, pois nos Estados Unidos há mescla de todos os povos do mundo: a verdade é que ao citar tal fragmento não nos dá a menor prova de sua modéstia e gênio pesquisador. A temperatura das diversas estações do ano em Santiago pouco se diferencia das [medições] dos diversos países ao meio-dia da Europa, particularmente de Nápoles, Toscana, Sicília, Toulon, Marselha, etc. Aqui raro é o ano em que a água não congela nas manhãs de inverno, e a temperatura do verão não passa de $30{ }^{\circ} \mathrm{C}$; mas ao sul, encontrará o sr. Gilliss, os pontos de comparação mais notáveis com as temperaturas dos países mais cultos da Europa. Se a maçã, as nozes, as castanhas e os pinheiros podem aqui adquirir frescor e vigor como na pátria de Leibnitz, Kepler, Laplace, não vejo razão para que o homem com toda a força de sua alma e coração não possa sob esse bonito céu elevar-se para a altura do seu destino. Três ou quatro graus de calor ou frio poderiam atiçar ou apagar o fogo que todo homem que abre os olhos para a luz divina sente no mais profundo de seu interior? Matéria de raças, competição de sangue, é uma miserável ideia, fomentada pelos materialistas de nosso século, como se já lhes faltassem ou se estivessem esgotados motivos mais decorosos para buscar queixas e semear ódios entre as nações. ${ }^{58}$

\footnotetext{
${ }^{57}$ Revista de Ciencias i Letras, op.cit., p.658. No original: "Principia por decir que el clima de Chile es mui agradable por su uniformidad i suavidad en qualquiera estacion del año. El mismo autor en otra parte de su obra se entusiasma por la belleza de nuestro cielo. Pero luego hace una advertencia mui singular, relativa a la impresion que ha ejercido sobre él i sus compañeros este temperamento encantador. Duda que esta suavidad i uniformidad del clima sean lo mejor para el progresso de la humanidad."

${ }^{58}$ Revista de Ciencias i Letras, op.cit., p.659. No original: "No se a que razas alude el señor Gilliss, pues en los Estados Unidos hai mescla de todos los pueblos del mundo: lo cierto es que en el citado trozo no nos da la mejor prueba de su modestia i jenio investigador. La temperatura de las diversas estaciones del año en Santiago poco se diferencia de la de los diversos estados del mediodia de Europa;particularmente de Nápoles, Toscana, Sicilia, Tolon, Marsella, etc. Aqui raro es el año en que el agua no se escarcha en las mañanas de invierno, i la temperatura del verano no pasa de 30 cent.; mas al sur hallará el senõr Gilliss puntos de comparacion mas notables con los temperamentos de los paises mas cultos de Europa.Si el
} 
Aqui, novamente podemos notar a defesa ampla do país que o acolheu. Domeyko fez uma tentativa que vai contra a maioria das teorias raciais e climáticas de sua época, usando para tais comparações climáticas a Europa. No que se refere às raças, lembrou que nos Estados Unidos havia gente de muitos lugares do mundo. Só faltou ser claro ao mencionar que a maioria vinha da Europa e, quanto aos da África, estes eram escravizados ou tidos como inferiores. Buscando mais de uma argumentação, Domeyko afirmou que tal visão era semeada não por teorias científicas, mas por materialistas que buscavam motivos para manter a opressão de povos menos favorecidos economicamente, de acordo com o meu entendimento.

Creio que o mais interessante em trazer a crítica ao relatório de Gilliss, seja justamente demonstrar que muitos dos países visitados nem sempre se calavam diante de declarações as quais por alguma razão não os agradassem. O que vimos acima foi uma defesa que ocorreu no mesmo ano da publicação do relatório. Infelizmente não foi possível encontrar dados sobre a repercussão de tais críticas, mas importa saber que elas existiram, já que tal conhecimento elimina a ideia de passividade dos países descritos de forma pejorativa nos relatos de viagem.

Domeyko nos ofereceu uma defesa de seu país utilizando argumentos que destoavam dos discursos da época. Assim como os Estados Unidos, ao longo dos séculos XVII e XVIII, pintou quadros e escreveu livros buscando desfazer a imagem de que seu país possuía uma natureza indomável, o Chile

manzano, el nogal, el castaño, el pino pueden aqui adquirir vigor i lozania como en la patria de Leibnitz, de Kepler, de Laplace, no veo la razon porque el hombre con toda la fuerza de su alma i corazon, no pueda bajo este hermoso cielo elevarse a la altura de su destino. Tres o cuatro grados de calor o frio podrian acaso atizar o entibiar aquel fuego que todo hombre que abre sus ojos a la luz divina siente en lo mas profundo de su interior? Cuestion de razas, competencia de la sangre, es una miserable idea, fomentada por los materialistas de nuestro siglo, como si les faltasen ya, o se les hubiesen agotado motivos mas decorosos para buscar querellas i sembrar odios entre las naciones." 
do século XIX igualmente buscou defender-se de construções imagéticas que o colocavam como um lugar condenado ao atraso e a apatia. 


\section{Capítulo V - A Argentina de Archibald MacRae}

Neste capítulo, busco analisar as representações sobre a Argentina elaboradas pelo oficial Archibald MacRae e pontuar as diferenças nos discursos produzidos por ele e James Gilliss sobre a América do Sul.

Quando os objetivos astronômicos da expedição foram cumpridos, Gilliss retornou para os Estados Unidos, mas Archibald MacRae recebeu a missão de atravessar os Andes e os Pampas argentinos. Seus registros inicialmente foram escritos em forma de diário, no qual anotou as informações que julgou pertinentes e posteriormente as usou como fonte para escrever o relato de viagem a ser incluído no relatório oficial da Expedição.

Gilliss incumbiu Archibald MacRae de atravessar as cordilheiras em direção à Argentina, com a finalidade de realizar observações relacionadas à topografia, latitude, longitude, dados sobre o clima e a meteorologia, etc. Passando pelos Andes, o oficial deveria atravessar o país até Buenos Aires, para finalmente retornar aos Estados Unidos. Durante esse percurso, deveria parar várias vezes e realizar suas medições. Além das observações listadas, MacRae tinha a tarefa de recolher dados sobre a geografia, a política e a cultura dos locais visitados.

Durante o trajeto, o oficial passou por situações perigosas, pois atravessou as cordilheiras por encostas estreitas montando em uma mula, dormiu muitas vezes ao relento e enfrentou temperaturas extremas. Guiado pelos chamados arrieros - homens contratados para levar viajantes até seu destino e cuidar da alimentação, dos animais e do fogo ao anoitecer MacRae atravessou a Cordilheira, iniciando pelo lado chileno dos Andes e seguiu rumo aos Pampas, passando por San Luis de la Punta, Rosário, Mendoza até alcançar Buenos Aires.

MacRae precisou fazer essa viagem duas vezes. Na primeira tentativa, em novembro de 1852 , seus instrumentos quebraram quando ele caiu de um 
cavalo no primeiro mês de sua incursão pela Argentina. Mesmo assim, o oficial percorreu o trajeto planejado, voltou para os Estados Unidos e alguns meses depois, em agosto de 1853, retornou com novos instrumentos para concluir a tarefa, à custa própria. Nesta segunda viagem, o autor atravessou novamente os Andes e os Pampas, mas desta vez, em direção contrária. Ele saiu de New York, aportou em Montevideo e de lá, tomou uma escuna até Buenos Aires, de onde seguiu viagem atravessando o interior da Argentina até chegar ao Chile, retornando para os Estados Unidos em janeiro de 1854. Foi principalmente durante a primeira viagem que grande parte das descrições sobre a Argentina foram elaboradas e anotadas no diário do oficial.

Conforme veremos, o relatório das duas viagens feitas por MacRae mostra um homem procurando afirmar-se frente ao comandante da expedição, já que não concordava como a forma com que o oficial apressou-se a fazer afirmações sobre os mais variados temas. MacRae, um pouco mais reservado, deixou julgamentos implícitos, mais do que explícitos. Ele procurou descrever o que viu, portanto "constatar", mais do que qualificar ou adjetivar o que observava, ainda que ele emitisse também opiniões. Entretanto, estas foram reduzidas em comparação com as expressas por Gilliss. Antes, portanto, de analisarmos as representações construídas por MacRae sobre a América do Sul, é necessário analisar o lugar de enunciação do viajante, lembrando aqui que MacRae era um sulista e Gilliss, um nortista. E, diferentemente do que ocorreu com Gilliss, cujas informações pessoais são escassas, pude encontrar alguns relatos biográficos sobre a trajetória de MacRae, os quais discuto a seguir.

\section{1 - Sobre Archibald MacRae}

Nascido em Wilmington, Carolina do Norte, em setembro de 1820, MacRae pertencia a uma família abastada, cujo pai, Alexander MacRae, imigrante escocês, se tornou um importante fazendeiro e empreendedor local. 
Ao final da década de 1830, ingressou na U.S. Navy, fato que agradou seu pai, que também fez uma importante carreira no exército norte-americano.

Em sua trajetória na Marinha, o oficial teve uma participação importante na Guerra contra o México (1846-1848). Antes do conflito, atuou como espião, passando-se por um oficial inglês. Após sua experiência na guerra, o oficial de trinta anos de idade partiu com Gilliss na expedição astronômica ao Chile. Durante os três anos que lá passou, parece ter desenvolvido uma forte amizade com Seth Ledyard Phelps, outro oficial que era membro da expedição astronômica, como já informado.

O jornalista norte-americano Chris Dixon nos conta que Archibald MacRae, após retornar da Argentina, ingressou em uma missão da Coast Survey no navio Ewing em 1855, que explorava as costas da Califórnia em busca do mapeamento da região para tornar a navegação mais segura. Durante essa missão, MacRae encontrou e mapeou o famoso Cortes Bank, local hoje aclamado por surfistas do mundo por suas gigantescas ondas, mas que na época, foi alertado por MacRae como uma perigosa rocha submersa na costa da Califórnia, a ser evitada pelos navios. ${ }^{1}$

MacRae, como muitos do seu tempo, mantinha o hábito de enviar cartas à família. Nelas comentou sofrer de reumatismo, doença que tornava a vida a bordo bastante difícil. Dixon afirma que pelas correspondências, notase o oficial aos poucos perdendo o entusiasmo, fazendo com que fossem escritas com menos frequência. $\mathrm{O}$ motivo dado pelo jornalista é que tudo era tão monótono, que MacRae pouco tinha a dizer. Em seu trabalho investigativo, Dixon encontrou elementos importantes sobre o estado de saúde do oficial durante a expedição na Califórnia. Além das cartas que ele enviava aos familiares, o jornalista teve acesso ao diário de um oficial que esteve em

\footnotetext{
${ }^{1}$ DIXON, Chris. Ghost wave : the discovery of Cortes bank and the biggest wave on earth.California: Cronicle Books, 2011. Chris Dixon obteve da família de MacRae toda a correspondência entre ele e sua família durante as expedições que realizou pela U.S. Navy. Além de gentilmente encaminhar-me as cartas, Dixon contribuiu com informações valiosas sobre a vida do oficial e as situações que enfrentou em seu percurso.
} 
constante companhia do viajante, chamado Philip Johnson Carrigan, no qual foi possível encontrar dados sobre a vida a bordo do Ewing e do comportamento de MacRae.

De acordo com o diário de Carrigan, o oficial passou a queixar-se de fortes dores de cabeça, associada às dores no corpo que sentia e que pioravam a cada dia. Por essa razão, após ter mapeado o Cortes Bank, decidiu aportar para consultar-se na Califórnia. O médico o encontrou muito debilitado e associou seu estado ao fígado. Sem respostas diante da medicação, MacRae foi tratado com opiáceos a fim de diminuir a dor. No diário, Philip Carrigan conta que ele dizia sentir o cérebro vibrar e já não aguentava mais tamanho incômodo. $\mathrm{O}$ oficial relatou em seu diário que muitas vezes, quando em crise e medicado com opiáceos, o autor relembrava suas experiências passadas, mencionando varias vezes o período em que esteve na América do Sul. O fato é que a dor não cedia. $\mathrm{E}$ foi assim que, duas semanas após descobrir o Cortes Bank, MacRae cometeu suicídio com uma bala de revólver na cabeça, dentro do navio. O oficial morreu a serviço do Coast Survey, aos trinta e cinco anos de idade, cerca de um ano após retornar de sua segunda viagem à Argentina. Antes de cometer suicídio, deixou uma carta testamento destinando a maioria de seus bens aos irmãos, enquanto que seus livros deixou como herança ao antigo colega da expedição astronômica, Seth Ledyard Phelps.

Chris Dixon acredita que o oficial sofria dos efeitos da malária, provavelmente contraída na América do Sul, e a doença e seus sintomas foram a causa do suicídio. $\mathrm{O}$ autor também nos conta que MacRae havia se apaixonado por uma chilena de Valparaíso e que em sua segunda viagem, a pediu em casamento, proposta provavelmente recusada, já que retornou sozinho para os Estados Unidos. Sobre seu suicídio, não podemos deixar de lado a possibilidade de um quadro depressivo, muito comum entre oficiais da Marinha. MacRae enfrentava uma viagem difícil, carregava consigo uma decepção amorosa e um quadro de debilitação física bastante grave. Mesmo 
sendo tratado com opiáceos, a carta de suicídio deixada por ele me pareceu bastante consciente, ou seja, não me parece que sua decisão tenha sido tomada em estado de convulsão emocional. As indicações são de que o oficial planejou dar fim a própria vida. Assim, ainda que esse não seja o meu objetivo aqui, pergunto-me se o suicido não decorreu de uma série de fatores, incluindo-se o uso dos tais opiáceos, que, somados, o levaram a este trágico fim.

Importante salientar que enquanto James Melville Gilliss era um nortista, Archibald MacRae era sulista, em um momento no qual o fosso entre as duas regiões dos Estados Unidos só aumentava. Provavelmente, os dois comungavam visões distintas sobre o país e sobre o mundo. Veremos que MacRae, ao tratar da Argentina, evitou utilizar muitos dos dispositivos discursivos usados por Gilliss, ainda que o que mostrasse fosse predominantemente negativo. As diferenças nos relatos dos dois oficiais serão examinadas à luz de uma importante documentação - as cartas pessoais de MacRae escritas ao seu pai e irmãos. Elas nos dizem muito sobre a expedição e sobre o olhar de alguns oficiais a respeito da qualidade do que foi produzido por James Gilliss e, de um modo geral, por viajantes daquele período.

\section{2 - A viagem e o relato: dilemas sobre a "fidedignidade" da escrita}

A partir das cartas enviadas por MacRae à família, pude constatar que houve conflitos entre ele e o comandante da expedição. ${ }^{2}$ Primeiro, o oficial claramente colocou em dúvida a veracidade de partes do relatório que seria escrito por Giliss:

O Senhor Gilliss ainda está conduzindo à frente esse livro e agora comenta em mandar suas anotações para o Secretário da Marinha com a esperança, eu suponho, de induzi-lo a solicitar a publicação

\footnotetext{
${ }^{2}$ Essas cartas, gentilmente enviadas pelo jornalista Chris Nixon, são cópias das originais, escritas a próprio punho por MacRae. Assim, informo que esta documentação foi transcrita por mim do original para o português.
} 
do mesmo. Não deve haver dúvidas de que o livro incluirá uma boa quantidade de informações, mas, do que eu conheço sobre ele [Gilliss], eu estou inclinado a pensar que ele misturará às boas informações muitas que são falsas, [especialmente] sobre os assuntos que ele não domina, como que para condenar efetivamente ele próprio, e talvez arrastar esse descrédito para outros membros da expedição, que, não fingindo terem qualquer tipo de conhecimento científico [tal como faz Gilliss], não podem se dar ao luxo de perder a nossa já pouca reputação como homens de bom senso.

A carta mostra que MacRae havia perdido a confiança em Gilliss. Ele temia que um relato de viagem pouco preciso viesse afetar a equipe. É provável que MacRae, cartógrafo, tenha imaginado que a sua reputação profissional viesse a ser comprometida pelo relato de viagem da expedição astronômica. A sua estratégia circunscreveu-se em construir um relato como ele considerava que deveria ser feito por um gentleman, com compromissos com a "verdade". Continuemos:

Ele recentemente respondeu a uma pergunta do Barão Humboldt, dizendo que uma das coisas que mais atraíram a sua atenção e a de sua pequena equipe - que, até onde eu saiba, isso é totalmente falso - foi a intensa cor vermillion [vermelho alaranjado] que a neve sobre a Cordilheira [dos Andes] assumia ao pôr do sol. Quando, na verdade, ela [a cor da neve] nunca vai além de um rosa delicado, e essa tonalidade só aparece quando [o céu] não está perfeitamente claro. Você logo verá que se ele fizer outras afirmações desse tipo em seu livro, será ridicularizado e, em tal ocasião, as pessoas talvez perguntem, se o comandante do grupo é tão ignorante, como seus assistentes devem ser? Eu devo confiar em sua conhecida astúcia e tato e esperar que antes de publicar seu livro, ele [Gilliss] o coloque nas mãos de pessoas capazes de corrigir seus erros em assuntos científicos, nesse caso, o comandante e o grupo receberão provavelmente muito mais crédito do que lhes é devido; mas, sobre essa última questão, não se deve reclamar, já que vivemos na era das farsas. Outro dia, nosso acompanhante, o Sr. Phelps, tentou fazer com que Giliss explicasse, como tinha feito ao Smith, a causa do fenômeno que descrevi acima, mas ele não conseguiu esclarecer, de onde eu deduzo que ele repensou sobre a matéria; e, assim que o correio 
levou sua carta contendo a afirmação sobre a cor da neve, ele confessou que não sabia exatamente o que vermillion era, e que quis dizer cor de rosa. Infelizmente, sua lembrança chegou muito tarde, e agora ele terá uma reputação de exagerar, o que para um homem das ciências é tão ruim como nenhuma outra reputação que ele pode ter. ${ }^{3}$

O excerto confirma algo que já se questionava: a aptidão dos oficiais da segunda metade do século XIX sobre o problema em tratar de assuntos dos quais não eram especialistas, bem como sobre a questão da fidedignidade do que era escrito com relação aos aspectos palpáveis da viagem, como geografia, geologia, etc.

A indignação de MacRae tornou-se explícita quando Gilliss escreveu ao famoso explorador prussiano Alexander von Humboldt sobre a cor da neve da Cordilheira dos Andes. MacRae apontou que aquele relatório estaria - a menos que um especialista fizesse as devidas correções - recheado de informações que não eram precisas.

Por outro lado, há um tom de conformismo com a atitude de Gilliss, já que, segundo MacRae, isso era comum em uma época que ele denominou

\footnotetext{
${ }^{3}$ MACRAE, Archibald. [Carta ao pai], 26 de maio de 1852, Santiago (Chile), para MACRAE, Alexander. Wilmington, South Carolina, 3 f. Relata os problemas sobre a falta de veracidade nas descrições de Gilliss sobre o Chile. Carta transcrita conforme manuscrito original. No original: "Mr. Gilliss is still driving ahead at this book and now talks of sending his notes to the Secretary of Navy with the hope, I suppose, of inducing him to order the publication of it. There can be no question that his book will contain a good deal of information, but from my knowledge of him I am inclined to think that he will mix up with the good information so much that is false about subjects which he does not understand as to effectively damn himself and perhaps to these discredit on the other members of the expedition, who not pretending to any real scientific knowledge cannot afford to lose our little reputation as men of common sense. He has recently in answer to a question of Baron Humboldt stated that one of the first things which attracted the attention of himself and his little party - which as far as I regard was entirely untrue - was the deep vermillion color that the snow on the cordillera assumed at sunset. When in fact it never gets beyond a delicate rose tint, and only that tint when it's not perfectly clear. [...]You will readily see that if he should make many statements of this kind in his book he will be laughed at and in such case people might say, if the chief of the plenty is so ignorant as this what must the assistants be? I shall rely on his known cunning and tact and hope that before publishing his book he will put it into the hands of some persons capable of correcting his errors in scientific matters, in which case the chief and his party probably receive more credit than it is actually due them; but of this latter we shant' complain as we live in an age of humbug. Our companion Mr. Phelps tried the other day to get Gilliss to explain to him as he had done to Smith the cause of the phenomenon of which I have spoken, but could not draw him out from which I infer he has thought he matter over, and since the mail has carried off his letter containing the statement of the color of the snow he has confessed that he did not exactly know what vermillion was, and meant rose color. Unfortunately, his memory served him to late, and he will now get the reputation for exaggerating, which for a scientific man is as bad as any of the reputations he can have."
} 
como "era das farsas". Assim, acredito que a carta apresentava um pensamento que tomava vulto naquele período, considerando que, a partir da segunda metade do século XIX, as especialidades ganhavam contornos e já tinham um espaço privilegiado e valorizado entre o meio intelectual e científico.

Portanto, diferentemente da imagem que podemos ter sobre os viajantes do fim da primeira metade do século XIX, em que se esperava que estes especialmente um oficial da U. S. Navy - fossem capazes de tratar dos mais variados temas, como de fato eram instruídos por seus superiores a fazê-lo, esta documentação permite inferir que havia discordância sobre isso. Na carta de MacRae, vimos que há uma preocupação com a ética da escrita e das informações contidas nos relatórios. Nela, MacRae também apontou que Gilliss, em busca de prestígio científico, passou por cima destas questões éticas. Ademais, temia que ele e os oficiais da expedição pagassem o preço de serem vistos com descrédito após a publicação do relatório.

Em outra carta, endereçada a seu irmão, o oficial demonstrou seu desconforto em cumprir as instruções dadas por Gilliss, em sua segunda viagem:

[...] Em primeiro lugar, aconteceu um fato nos últimos dias que talvez altere bastante o aspecto das coisas. Gilliss, em múltiplas ocasiões, me escreveu para que eu submetesse a ele as principais instruções que eu gostaria de levar [para a segunda viagem] e eu o respondi, tão frequentemente, que eu não queria nenhuma instrução, e sim apenas uma permissão para ir aonde eu quisesse e como eu quisesse. Bom, no sábado, ele me disse que escreveu um rascunho [das instruções], sobre o que ele desejava que eu examinasse e que, se eu julgasse necessário, sugerisse alterações. Eu levei as folhas de papel para casa e li, mas fiquei tão aborrecido com aquilo que fui para Baltimore para esfriar os ânimos. Quando voltei, Gilliss havia partido para New York e ainda está lá. Quando ele voltar, eu vou mandar a tal carta a ele, da forma que eu quero, e, se ele não assiná-la, eu vou por conta própria ou simplesmente não vou. Você verá em um ou dois trechos das suas instruções [de 
Gilliss] o quanto eu fui colocado em uma posição de um colegial que foi mandado de volta para trazer o seu dever de casa. ${ }^{4}$

MacRae reproduziu parte da instrução de Gilliss na carta ao irmão, provavelmente justificando a sua posição, e esperando apoio:

\begin{abstract}
"Uma solicitação foi feita ao Exmo. Secretário da Marinha, ele concedeu permissão para o seu retorno por Buenos Aires e os Andes, a fim de aferir determinações geográficas e outras que você foi impedido de realizar durante o seu retorno do Chile, pelo inevitável dano à parte de seus instrumentos. Sendo assim, você deixará os Estados Unidos com esse propósito o mais brevemente possível, e levará consigo os equipamentos necessários para a conclusão satisfatória das instruções dadas a você em 15 de setembro do ano passado." [...]

Gilliss também sugeriu que eu determinasse a posição geográfica dos principais lugares e da estrada [de correios] do sul de Santiago pelo menos até Talca. A razão disso é que ele foi para ao sul em uma jornada científica e negligenciou essa tarefa e, agora arrependido, ele que obter [esses dados]. ${ }^{5}$
\end{abstract}

\title{
O excerto acima demonstra a insatisfação do oficial diante da obrigação
}

\section{em cumprir instruções as quais ele não concordava, já que exigiam que ele}

\footnotetext{
${ }^{4}$ MACRAE, Archibald. [Carta ao irmão], 20 de julho de 1852, Washington D.C., para MACRAE, John C.. Wilmington, South Carolina, 4 f. Nessa carta, ele pede opinião para o irmão sobre o que fazer a respeito das instruções de Gilliss, que ele não desejava cumprir. Carta transcrita conforme manuscrito original. No original: [...] "In the first place, there has occurred an event within the last few days which may alter the aspect of affairs very much. Gilliss has in several occasions told me to submit to him the heads of such instructions as I should like to have and I have as often answered that I did not want any instructions, but merely permission to go how I pleased and where I pleased. Well, on Saturday he told me that he had written out a rough copy which he wished me to see and if I thought proper to suggest any alterations. I took the paper home with me and read it and was so annoyed with it that I went off to Baltimore to cool. When I returned, Gillis had gone to New York and is there still. On his return I will submit such a letter to him as I want and if he does not sign it will either not go at all or will go on my own hook. You will see by one or two extracts from his instructions how completely I am placed in the position of a whipped school boy who has been sent to get back his lesson over."

${ }^{5}$ Ibidem.

"A request having been made to the Hon. Secretary of the Navy, he has granted permission for your return across Buenos Aires and the Andes in order to make such geographical and other determinations as you were prevented from doing on the return from Chile by unavoidable injury to a part of your instruments. You will therefore leave the U.S. for this purpose at the earliest date practicable and take with you such instruments belonging to the Expedition as will be required for the satisfactory completion of the instructions given you on the 15 sept, last year." [...]

Gilliss also suggests that I shall determine the geographical position of all the principal places and the post road to Santiago south as least and as far as Talca. The reason of this is that he went south once as a scientific journey and neglected to do this and now that he is meeting his repent he feels the want get."
} 
relatasse sobre assuntos em que não era um especialista. Mais: o oficial, constrangido, viu-se cobrado como um menino. O que era difícil para um oficial da U. S. Navy que havia atuado na Guerra com o México e servia à arma em expedições de diferentes tipos, mas principalmente nas que exigiam o trabalho de cartógrafos.

Isso talvez explique as razões do relato curto, com sessenta e sete páginas e com uma apresentação muito distante daquela realizada por Gilliss. Esse descrédito não incluiu obviamente as observações astronômicas, especialidade que Gilliss dominava. Este excerto informa também que o comandante da expedição o instruiu a realizar um mapeamento das estradas por onde seguiam os correios, do sul de Santiago até Talca — obrigação que era de Gilliss, mas que este não realizou. Podemos imaginar, pelo tom da carta, que MacRae não ficou satisfeito em receber tal missão, tampouco com as instruções, as quais ele já havia dito a Gilliss, segundo consta na carta, que não desejava receber.

Por outro lado, ainda que o oficial tenha retornado à custa própria, esta não deixava de ser uma missão oficial do governo. Vemos aqui como essa mistura entre os interesses pessoais e as obrigações profissionais criaram problemas. Ao pagar por sua viagem, vemos aflorar no oficial a conhecida "honra sulista", que tornou MacRae desejoso de cumprir com o dever que não conseguiu realizar da primeira vez, ainda que tivesse de arcar com os custos da viagem. Por outro lado, a discordância dos métodos de Gilliss, que misturavam, a seu ver, ficção com realidade, criou uma resistência por parte do oficial em cumprir ordens de seu superior. Veremos que MacRae, ao final, acabou cumprindo parcialmente as solicitações, e, como já dito, produziu um relato que buscou algum distanciamento daquele feito pelo chefe da expedição. Discutiremos também que essa intenção está explicita no próprio relatório, quando o oficial afirmou que não relataria aspectos do país que somente um especialista seria capaz de fazer com a devida competência. 


\section{3 - James M. Gilliss, Archibald MacRae e as diferenças nos relatos da expedição}

Em uma análise comparativa com o relatório produzido por Gilliss e também levando em consideração os relatos oficiais de viagens escritos ao longo do século XIX, nota-se em MacRae uma escrita que destoou dos demais, já que ele não se valeu de outras fontes, tais como relatos de outros viajantes, revistas e censos locais. Inclusive, o oficial fez questão de enfatizar em seu texto, que só nos contou aquilo que viu - afirmação esta que também será problematizada ao longo do capítulo. As cartas escritas por MacRae aos seus familiares explicam parcialmente os motivos de tal postura do viajante, como já discutimos.

MacRae, durante a primeira viagem, pareceu escrever com mais entusiasmo, característica que não se repetiu em suas descrições durante a sua segunda jornada. Creio que as diferenças com Gilliss influenciaram nessa escrita que se mostrou, muitas vezes, uma obrigação. E, como vimos, seu temperamento forte aliado à sua concepção de como deveriam ser dispostos os dados, a obtenção de determinado conhecimento, no relatório de uma viagem científica, o fez questionar o oficial superior, não cumprindo algumas instruções que lhe foram dadas. O resultado foi um descritivo relatório curto, em confronto com o superior que lhe enviara à Argentina pela segunda vez para completar o "dever de casa".

Durante sua viagem à Argentina, notamos que MacRae buscou, muito a contragosto, atender algumas das solicitações feitas por Gilliss. Exceto as medições astronômicas, o oficial narrou apenas aquilo que considerou ser capaz de realizar. Ao chegar a Mendoza, por exemplo, o oficial fez uma listagem dos rios pelos quais passou até chegar ao local, indicando larguras e profundidades. Aqui, nota-se o interesse em mapear os rios navegáveis da região. Na Villa de Rio Cuarto, conseguiu obter um censo populacional, o único publicado no relatório, junto a dois mapas, um fluvial e outro de 
localização geográfica. Assim, diferentemente de Gilliss, o oficial ofereceu poucos dados científicos sobre os países que visitou.

MacRae também procurou descrever a paisagem e os animais que encontrou, mas, uma característica bastante incomum me chamou a atenção em seus escritos: sua recusa, explícita, em tratar de determinados temas comuns em relatos de viagens oficiais, como se ele fosse um especialista ou alguém capacitado para realizar múltiplas tarefas:

Após terminar a minha narrativa, tanto quanto possível ligada aos Pampas, eu me empenharei em trazer uma ideia geral sobre o país da forma mais concisa possível; estabelecendo como premissa que eu nada sei de geologia, mineralogia, botânica, ou, de fato, de nenhuma das "ologias"; eu não posso falar tecnicamente sobre esses assuntos. ${ }^{6}$

De fato, o oficial cumpriu com o que afirmou e com o que mencionou nas cartas que analisamos. Não há em seu relatório qualquer indício de pretensão por parte do autor em ser preciso ou aprofundado em descrições relacionadas aos temas que não dominava. Tampouco houve constrangimento em não fazê-lo. Sobre os animais que encontrou:

Leões e tigres são considerados comuns nos pântanos, mas eu não os vi. Nós vimos um toirão [furão selvagem] e duas ou três iguanas, mas se eles são comuns ou não, eu não sei. ${ }^{7}$

Como se sabe, não há leões e tigres na Argentina. Podemos inferir que a resposta "eu não sei" poderia ter sido suprida através de pesquisa pós-

\footnotetext{
${ }^{6}$ MACRAE, Archibald. "Report of a journey across the Andes and Pampas of the Argentine Provinces". In: GILLISS, James Melville. The U.S. Naval Astronomical Expedition to the Southern Hemisphere during the years 1849-'50-'51-'52. Washington: A.O.P. Nicholson Printer, 1855, v. 2, p. 67. No original: Having finished my narrative as far as it is connected with the pampa, I will endeavor to give a general idea of the country in as condensed a form as possible ; premising, that as I know nothing of geology, mineralogy, botany, or, indeed, of any of the " ologies," I cannot speak technically on these subjects.

${ }^{7}$ MACRAE, op. cit., p. 55. No original: "Lions and tigers are said to be common among the marshes, but I saw none of them. We saw one polecat and two or three iguanas, but whether they are common or not I do not know."
} 
viagem, como era praxe no período. O único esforço do autor para colaborar com especialistas, ao fim de sua segunda viagem, foi o de pagar cinquenta centavos por cada espécime que os locais recolhessem e dessem a ele. Aqui, notamos que o autor procurou levar da viagem elementos que seriam analisados não por Gilliss, mas por outros especialistas que contribuíram com o relatório. Também é preciso considerar que as províncias visitadas não apresentavam a organização de dados por parte do governo, como as que Gilliss encontrou para rechear seu relatório sobre o Chile.

Os locais pelos quais MacRae passou, em sua maioria, eram pequenas vilas, cujas administrações não possuíam ainda dados precisos como censos, por exemplo. Assim, até mesmo o número de pessoas que habitavam os lugares por ele visitados foi descrito como estimado. Por onde viu plantações, o oficial as relatou, por onde viu territórios secos e inóspitos, ele os descreveu. Cada tempo de cavalgada de um lugar a outro foi determinado, cada pessoa que ele conheceu e cada cidade que visitou foi contada em seu relato. Destacou-se na escrita de MacRae, as descrições sobre o modo de vida dos locais e não a obstinação em exposições longas e empenhadas em transmitir a suposta "precisão científica" encontrada na parte do relatório produzido por Gilliss.

\section{4 - A Confederação argentina de Justo José de Urquiza}

Antes de iniciarmos as análises das representações em seu relato, é importante compreender as condições políticas em que se encontrava o interior da Argentina.

No período em que o oficial realizou sua primeira viagem, o país passava por uma grande mudança política. No início de 1852, caia o governo de Juan Manuel de Rosas. Nesse momento os argentinos se dividiram política e economicamente entre a Confederação Argentina, comandada pelo general 
Justo José de Urquiza e a província de Buenos Aires, governada por liberais liderados por Bartolomé Mitre e Adolfo Alsina. ${ }^{8}$

O caudilho Justo José de Urquiza foi um governador anti-rosista e líder provinciano federalista de Entre Ríos que, em um período de grave disputa interna no país, possuía habilidades políticas que lhe garantiram trânsito entre alguns unitários. ${ }^{9}$ Grande proprietário de terras e dono de navios, além de ter negócios na indústria do charque, possuía grande influência entre as elites locais. Em 1852, Urquiza foi nomeado Diretor Provisório da Confederação Argentina pelo Acordo de San Nicholás. ${ }^{10}$ Assim, durante a primeira viagem de MacRae, a Argentina acabara de passar uma grande mudança política.

Em sua segunda viagem, em 1853, foi promulgada a Constituição Argentina e neste momento a região passou por outro tipo de divisão: a Província de Buenos Aires declarou a separação da Confederação, cuja capital passou a ser Rosário, e recebeu o nome de Estado de Buenos Aires. Apesar das alianças que permitiram a derrocada de Rosas, Buenos Aires recusara-se a se submeter novamente a um Federalista. ${ }^{11}$ Portanto, nesse período, o país estava dividido entre o grupo herdeiro dos Unitários - liberais influenciados por ideias europeias que lutavam por um governo centralizado a partir da cidade de Buenos Aires - e o grupo dos Federalistas, que concentrava líderes que lutaram e mantiveram uma Confederação por algumas décadas, sustentando o poder das províncias sobre a cidade Buenos Aires. Segundo Marcela Tarnavasio, os caudilhos tinham em comum, a oposição ao centralismo, a reivindicação de liberdades e autogoverno local e um apelo

\footnotetext{
${ }^{8}$ CHIARAMONTE, José Carlos. Cidades, Províncias, Estados: Origens da Nação Argentina (1800-1846). São Paulo: Hucitec, 2009.

${ }^{9}$ BEIRED, José Luis Bendicho. Breve História da Argentina. São Paulo: Editora Ática, 1996.

${ }^{10}$ Cf. MOREIRA, Marília Arantes Silva. "Expectativas e impasses dos sulistas norte-americanos no Estuário do Prata: a questão da navegação dos rios e a viagem do comandante da U.S. Navy, Thomas Jefferson Page (1853 - 1860)". Artigo de dissertação de conclusão de Mestrado ao Instituto de Relações Internacionais da Universidade de São Paulo, 2013.

${ }^{11}$ Idem, p. 21.
} 
popular ou a convicção de que aqueles estancieiros-líderes regionais gozavam de adesão da maioria da população. ${ }^{12}$

Durante as duas viagens que MacRae realizou pela Argentina, o oficial não presenciou os conflitos diretos entre os unitários liberais (a maioria concentrados em Buenos Aires) e Federalistas, também chamados de caudillos, estes, concentrados principalmente no interior da Argentina. Aqui, vale mencionar que em 1853, a U.S. Navy enviou uma expedição ao rio da Prata comandada por Thomas Jefferson Page, com o objetivo de "realizar trabalhos científicos na região e diplomáticos para negociar em favor da livre navegação dos rios da região, além de estabelecer tratados comerciais" ${ }^{13}$

MacRae percorreu o interior da Argentina, liderado por Urquiza. Segundo Ariel de La Fuente, as elites locais motivadas pelo interesse em manter a Confederação forte diante das pressões e disputas com os liberais unitários de Buenos Aires, se associaram aos gauchos, camada pobre e campesina do interior.

Era preciso negociar o apoio dos gauchos dentro das tradições e símbolos, portanto dos significados do federalismo (...), uma identidade política que mantinha cativa a lealdade da maioria dos gauchos. $^{14}$

Ainda segundo o mesmo historiador,

Estas dificuldades para mobilizar os gauchos surgiam não apenas das próprias limitações políticas dos unitários, mas da incessante politização dos gauchos. Eram federalistas e, inclusive, em 1867 também chachistas, o que definia seu modo de participar nas lutas políticas. $^{15}$

\footnotetext{
${ }^{12}$ Cf.: TERNAVASIO, Marcela. Prólogo. In: El pensamiento de los Federales. Buenos Aires: Editorial El Ateneo, 2009, p. 10.

${ }^{13}$ Idem, p. 4.

${ }^{14}$ DE LA FUENTE, Ariel. Los hijos de Facundo: caudillos y montoneras en la Provincia de La Rioja durante el proceso de formación del Estado Nacional Argentino (1853-1870). Buenos Aires: Prometeo, 2007, p. 146.

15 Idem, p. 151.
} 
Chachistas eram os que apoiavam Chacho Peñaloza, caudilho de La Rioja, região próxima à Mendoza. Urquiza, líder político da Confederação, detinha a função de coordenar o debate político com as diferentes províncias do interior da Argentina e fazer frente à Buenos Aires.

Urquiza teve também uma importante atuação entre os cacicados indígenas do período, sendo capaz de realizar tratados de paz e acordos comercias com as principais tribos indígenas do país. Aqui, é importante mencionar que tais acordos se deram a partir de uma forte negociação por parte dos líderes indígenas, que buscaram se beneficiar e demonstraram ampla capacidade de agência política nesse processo. Este importante e interessante tema foi amplamente estudado pelo historiador Gabriel Passetti, que realizou uma pesquisa inovadora sobre as Campanhas do Deserto. ${ }^{16}$

\section{5 - As representações de Archibald MacRae sobre a Argentina}

MacRae e Gilliss construíram representações e imagens sobre a América do Sul. Ainda que ambos acabem por focar em aspectos considerados negativos da região, houve diferenças entre os dois na forma de narrar o que viram, como já dito. Enquanto Gilliss apresentava claramente sua visão depreciativa sobre o outro, qualificando-o, julgando-o, fazendo uso de adjetivos, muitas vezes elaborando contrastes em relação aos Estados Unidos, MacRae procurava se distanciar de seu objeto de análise. Ainda que emitisse juízos de valor, ele usou como principal recurso discursivo, a descrição e a constatação sobre o que viu permeada de forma sutil por julgamentos. No

\footnotetext{
${ }^{16}$ Cf: PASSETTI, Gabriel. Indígenas e Criollos: Política, guerra e traição nas lutas no sul da Argentina (1852-1885). São Paulo: Alameda, 2012. Sobre a questão indígena e as tensões políticas na Argentina da segunda metade do século XIX, ver também: BUCHBINDER, Pablo.Caudillos de pluma y hombres de acción. Estado y política en Corrientes en tiempos de la organización nacional. Buenos Aires: Prometeo, 2014; GOLDMAN, Noemí; SALVATORE, Ricardo (comp). Caudillismos rioplatenses: nuevas miradas a um viejo problema. Buenos Aires: Eudeba, 2005; DE LA FUENTE, Ariel. Los hijos de Facundo: caudillos y montoneras en la Provincia de La Rioja durante el proceso de formación del Estado Nacional Argentino (1853-1870). Buenos Aires: Prometeo, 2007; RODRÍGUEZ, Fermín A. Un desierto para la nación: la escritura del vacío. Buenos Aires: Eterna Cadencia, 2010; SÁ, Maria Elisa Noronha de. Civilização e barbárie: a construção da ideia de nação - Brasil e Argentina. Rio de Janeiro: Garamond,2012; SANTILLI, Daniel; GELMAN, Jorge Daniel; FRADKIN, Raúl Osvaldo (comps.) Rebeldes con causa. Conflicto y movilización popular en la Argentina del siglo XIX. Buenos Aires:Prometeo,2014.
} 
correr da pesquisa, foi mais fácil compreender a posição de Gilliss, do que a do inconformado e ressentido MacRae. Apesar de proporcionar ao leitor uma maior margem para interpretações diversas, ainda assim o viajante, como veremos, fez uma avaliação sobre a sociedade que visitara.

Em Mendoza, o oficial descreveu uma província cujo governo e população viviam de acordo com o que ele chamou de "simplicidade republicana":

Sobre a casa do governo [...] paira um ar da mais simplicidade republicana. Na verdade, o mesmo pode ser dito do lugar como um todo, não apenas no que diz respeito à aparência do edifício, mas também nos costumes do povo. A julgar pelo que vi, há pouquíssima aspiração para a superioridade entre aqueles que são autoridades, ou entre os abastados de bens materiais; e a aristocracia "do vestido" não progrediu ao ponto de fazer mulheres respeitáveis se sentirem envergonhadas de serem vistas em calico [tecido grosseiro de algodão, fabricado na Índia]. Há, dessa forma, um maior sentimento de igualdade do que é habitual em uma comunidade tão grande quanto esta. ${ }^{17}$

Simplicidade republicana era uma virtude para os norte-americanos, incluindo-se nortistas e sulistas. O oficial retratou uma população como essencialmente simples, independentemente da classe social, ou seja, mesmo aqueles que detinham posses e poderes políticos eram simples. É certo que o regime republicano aqui está colocado como positivo, tendo como contraponto a Monarquia.

Em outro momento o autor descreve outra situação na qual identifica relações democráticas entre as classes sociais:

\footnotetext{
${ }^{17}$ MACRAE, op. cit., p. 16. No original: "The government house[...] and in other respects has about it an air of most republican simplicity. Indeed, the same may be said of the whole place not only in regard to the appearance of the building, but also of the manners of the people. Judging from what I saw, there is very little offensive pretension to superiority on the part of those in authority, or well to do in worldly goods; and the aristocracy of dress has not progressed so far as to make a respectable woman ashamed to be seen in calico. There is, therefore, a greater feeling of equality than is usual in so large a community."
} 
Uma coisa notável de Mendonza a Rosário é a democracia perfeita da sala de bilhar. Nas associações, não é raro ver um coronel no mesmo jogo de um soldado comum, o dândi com o vadio, ou o rico empregador com o trabalhador esfarrapado e sujo. Na verdade, a única qualificação requerida era o dinheiro para participar. ${ }^{18}$

MacRae aqui constatou a aproximação entre segmentos distintos da sociedade, fato que classificou como notável. Mas nesse excerto, o termo "democracia perfeita" parece uma ironia do oficial. Nota-se que ele descreveu essa associação em um ambiente de jogo, algo visto entre norte-americanos protestantes como negativo. O jogo normalmente era percebido como algo tão viciante como o álcool. E em seu relato, são recorrentes as descrições de homens brancos e índios como bêbados. Assim, sem criticar diretamente, ele o faz de forma implícita, pois a democracia perfeita ocorria em um ambiente desmoralizador — uma casa de jogos.

Diante de tal associação, o autor constrói uma narrativa em que constata que no interior da Argentina a elites locais não apresentavam um comportamento hierarquizado e jactancioso. Mesmo essa população pertencente à elite política, especialmente os caudillos, não se portava de acordo com sua posição, ou seja, eram todos rústicos. Ademais, creio que o autor não compreendeu a necessidade política de se formar vínculos entre gauchos e as elites. O desafio aqui, e em outros excertos, está no dispositivo discursivo que o autor utiliza: ele narrou as cenas, mas em geral, deixou ao leitor a tarefa de realizar julgamentos. Assim, ele afirmava sua posição e o seu descontentamento com o relato de viagem de James Melville Gilliss. Quer-se dizer que a disputa entre os dois emerge nas escolhas discursivas de MacRae.

O autor seguiu em sua descrição de Mendoza, apontando não apenas os baixos salários dos funcionários públicos, mas inferindo que lá, as pessoas

\footnotetext{
${ }^{18}$ MACRAE, op. cit., p. 17. No original: "One thing remarkable from Mendoza to Rosario is the perfect democracy of the billiard-room. At pool it is not unfrequent to see a colonel in the same game as the common soldier, the dandy with the loafer, or the rich employer with the ragged and dirty laborer. Indeed, the only qualification required is the necessary money to enter."
} 
não tinham as mesmas facilidades em "acumular fortunas por meios desonestos, como em algumas partes da América do Sul. ${ }^{19}$ Afirmou também que apesar de possuírem poucas posses e terem passado por guerras civis, mantinham-se otimistas e convictos de que sua cidade estava destinada a ser grande:

\begin{abstract}
As pessoas parecem ter pouco, ou querer pouco; e, não obstante elas terem se envolvido recentemente em guerras civis, todo o sentimento partidário parece ter se extinguido, e, em seu lugar, elas adotaram uma ideia inofensiva de que Mendoza é uma grande cidade, e que, pela sua posição geográfica, está destinada a impressionar o mundo, muito em breve; e, ao abrigo de tal crença, elas se relacionam pacificamente e felizes como poderia ser desejado até em Utopia. ${ }^{20}$
\end{abstract}

Importante ressaltar que os excertos colocados aqui são aqueles que o oficial emite, de uma forma ou de outra, julgamentos. A posição do oficial acima se relaciona com a do excerto anterior no qual ele constatou que eram "simples", atributo próprio dos republicanos. Ser republicano, como sabemos, não significa propriamente defender a igualdade social.

Acredito que MacRae tenha citado o famoso livro "Sobre o melhor estado de uma república e sobre a nova ilha Utopia" ou como é mais conhecido, "Utopia", escrito em 1516 por Thomas Morus, no qual o autor idealizou uma ilha com uma organização política perfeita e uma sociedade igualitária, criticando ferozmente os sistemas de governo da Europa. Nota-se que a suposta igualdade vista por ele em Mendoza o fez pensar no romance de Morus. MacRae nos parece também um tanto pessimista: ele considera inofensiva a alusão de que Mendonza era uma cidade grande, mas é possível

\footnotetext{
${ }^{19}$ MACRAE, op .cit., p. 17. No original: [...]" and there does not appear to be the same facility for them to accumulate fortunes by dishonest means, as in some other parts of South America."

${ }^{20}$ MACRAE, op. cit., p. 16. No Original: "The people appear to have but little, or want but little; and notwithstanding they have recently been embroiled in civil wars, all party feeling seems to be extinct, and in its place they have adopted the harmless idea that Mendoza is a great city, and, from its geographical position, destined soon to astonish the world; under which belief they get along as peaceably and happily as could be desired even in Utopia."
} 
que tenha avaliado a posição como ingênua. $O$ mais provável é que apesar de republicano, como um bom sulista, ele não acreditava em igualdade, esta não passava de uma utopia para oficial, já que a humanidade era vista pela maioria dos sulistas como naturalmente desigual.

Sobre a saúde da população, o oficial fez uma análise pautada na lógica e em possíveis explicações científicas para compreender as razões pelas quais as populações mais pobres eram as mais acometidas por doenças. Sobre o Bócio, por exemplo, afirmou:

[...] Não pode haver dúvida de que ela [a doença] é ocasionada pelo uso da água do Rio de Mendoza, ou, melhor dizendo, de Sanjon, que vem de Mendonza, a cinco léguas ao sul; a doença é quase inteiramente confinada às classes baixas, que não podem pagar pela água da nascente trazida por mulas. ${ }^{21}$

Se Gilliss atribuiu as doenças nos países que visitou aos maus hábitos dos pobres, MacRae as relacionou ao fato de que a prevalência das doenças nessa camada da população ocorria por estas não possuíam dinheiro para pagar a água fresca e sem contaminações, trazida por vendedores que as buscavam nas nascentes dos rios. Ou seja, aonde um autor enxergou a doença como decorrente de maus hábitos típicos das classes mais baixas, o outro associou à falta de recursos em obter água sem contaminação. Aqui, novamente o autor constatou algo: a pobreza extrema dos habitantes do interior da Argentina que não podiam sequer comprar água. $\mathrm{O}$ julgamento encontra-se implícito, diferentemente das explicitações próprias de Gilliss. A constituição de imagens negativas da Argentina por parte de MacRae está nas escolhas dos temas que decidiu tratar. Ele não emitiu juízo de valor explicitamente no excerto acima, mas informou ao público norte-americano

\footnotetext{
${ }^{21}$ MACRAE, op. cit., p. 16. No original: "There can be but little doubt that it is produced by the use of the water of the Rio de Mendoza, or rather of the Sanjon, which comes from the Mendoza, five leagues to the southward, as the disease is almost wholly confined to the lower classes, who are unable to pay for the spring-water brought in on mules."
} 
que parte da população da região árida do interior da Argentina não pode sequer comprar água, utilizando o rio contaminado, o que fazia com que grassasse ali a doença. Certamente, quem viesse a ler tal texto não teria uma imagem positiva da região.

Apesar de identificar que os crimes ocorriam principalmente entre as classes mais baixas, o viajante classificou a população das províncias de forma positiva:

Um dos crimes mais comuns em Mendoza é o roubo. O assassinato, exceto em brigas, e ocasionalmente por vingança, é bastante raro; e, de modo geral, as classes baixas, entre as quais esses crimes usualmente se restringem, são um povo pacífico, civil e de boa índole $[. . .]^{22}$

Embora reconheça a existência dos crimes, notemos que ele afirmou que estes não eram comuns e, portanto, ao caracterizar a população como sendo de boa índole, indiretamente nos diz que tais ocorrências não representavam o caráter daquelas pessoas, principalmente por que ocorriam raramente. Aqui, ele faz um julgamento positivo da sociedade, e usa o termo "civil", também atributo dos republicanos. É provável que MacRae fosse adepto da ideia de mais poder local, do que do poder central. Tal suposição nos leva novamente ao lugar de enunciação do oficial. Ele era um sulista também provavelmente defendendo o poder local da região sul dos Estados Unidos em momento em que a dissensão começava a aprofundar.

A hospitalidade por parte dos caudillos locais também foi tema recorrente em seu relato. Em Mendoza, fez questão de mencionar o nome de pessoas que lhe foram prestativas em sua passagem por lá e descreveu como o governo local e sua população estavam empenhadas em trazer melhorias à cidade:

\footnotetext{
${ }^{22}$ MACRAE, op. cit., p. 17. No original: "Of crimes the most common in Mendoza is theft. Murder, except in brawls, and occasionally for revenge, is very rare; and generally speaking, the lower classes, among whom those crimes are usually confined, are a peaceable, civil, and good-natured people."[...]
} 
Do pouco que eu vi da alta sociedade do lugar, eu fiquei favoravelmente impressionado. [...] O governo, apesar de tolhido de seus meios, se esforçava para melhorar a condição de estradas e pontes. Um grupo de pessoas trabalhava nas montanhas limpando as estradas até o Cumbre e uma boa ponte estava sendo construída, sob os auspícios de Don Carlos Maria de Rivarola, pelo Rio de las Vacas. Eu menciono o nome desse cavalheiro para afirmar que ele foi gentil e atento comigo o tempo todo, e me prestou toda ajuda possível em seu poder para o cumprimento do meu dever. Através de sua apresentação, eu obtive de uma senhora extremamente interessante e amável, que possuía uma charmosa dificuldade de fala, o uso de um belo vinhedo sombreado. Aqui, debaixo do abrigo [das sombras], e revigorado, de vez em quando, por um ponche de rum ou uma limonada feita pelas mãos da própria senhora, eu fui possibilitado de completar o meu trabalho. Don Carlos era coronel do governo Rosas, mas por alguns anos tem sido chefe do departamento de engenharia de Mendonza; e, apesar de nunca ter tido uma formação de engenharia, ele tinha um excelente conhecimento prático, que é bastante adequado às necessidades do país. ${ }^{23}$

Neste excerto, notamos outra característica destoante do restante do relatório produzido por Gilliss sobre os outros países visitados, pois MacRae reconheceu que viu pouco sobre a sociedade, diferentemente de Gilliss, que também viu pouco, mas não se deteve em julgar e passar a imagem de que muito conheceu sobre os lugares em que esteve. Não há, em nenhum momento de seu relato durante a estadia em Mendoza, uma única crítica depreciativa sobre os caudillos. Provavelmente, o sulista MacRae não visse a atuação daqueles homens como completamente negativa, apesar da proximidade que às vezes relatava entre os políticos e peões.

\footnotetext{
${ }^{23}$ MACRAE, op. cit. p. 18. No Original: "From the little I saw of the polite society of the place, I was very favorably impressed. [...] The government, although hampered in its means, was endeavoring to improve the condition of the roads and bridges. A gang of hands was at work in the mountains clearing the road as far as the Cumbre, and a fine bridge was being built, under the direction of Don Carlos Maria de Rivarola, for the Rio de las Vacas. I mention this gentleman's name in order to state that he was universally kind and attentive to me, and rendered me any assistance in his power in the discharge of my duty. Through his introduction I obtained from an exceedingly interesting and amiable lady, with a charming impediment in her speech, the use of a fine shady vineyard. Here, under shelter and refreshed now and then by a rum punch or lemonade made by the lady's own hand, I was enabled to complete my work. Don Carlos was colonel under Rosas, but for some years has been chief of the engineer department in Mendoza ; and, although never educated as an engineer, he has very excellent practical knowledge, and is quite suited to the wants of the country."
} 
Se, para Gilliss os homens chilenos invejavam os estrangeiros "enérgicos e inteligentes", para MacRae os caudillos argentinos eram solícitos e demonstravam competência e energia para cuidar de sua província. Lembro aqui que há entre estes e MacRae algo em comum: ambos eram proprietários de terras. Lembro também que o próprio Urquiza era um caudillo. No entanto devemos indicar que MacRae, como vimos a partir de suas críticas ao relatório escrito por Gilliss, prezava pela formação especializada. Talvez aqui, o autor tenha considerado que, para a situação "simples" da região, a solução apresentada era viável. Assim, enquanto Gilliss desvalorizou a qualificação profissional dos chilenos e sua apatia para o trabalho, MacRae relatou que na Argentina, homens comuns faziam com eficiência o trabalho de graduados e, além disso, possuíam disposição para o trabalho. Portanto, em um local cujo conhecimento prático era a única opção, MacRae pareceu não se incomodar com a questão das especialidades.

Ao sair de Mendoza, o oficial seguiu em direção a San Luis de La Punta. No trajeto, o autor manifestou o medo de encontrar índios pelo caminho, devido às histórias que ouvira. A caminho de seu destino, deixou escapar, de forma solta, no meio do texto, um temor até então não expressado:

Descobri que uma de minhas pistolas havia sido roubada ou perdida; o que foi bastante angustiante, considerando o número de histórias contadas sobre o perigo dos índios. ${ }^{24}$

MacRae estava a par dos acontecimentos que envolviam ataques indígenas, como os malones - invasão indígena a estâncias em busca de gados e objetos de valor - que, embora no período em que esteve na Argentina estivessem restritos praticamente à região de Buenos Aires, ainda tomavam conta do imaginário da população. Durante sua estadia na pequena

\footnotetext{
${ }^{24}$ MACRAE, op. cit. p. 21. No original:"Discovered that one of my pistols had either been stolen or lost; which was rather distressing, considering the number of stories told of danger from the Indians."
} 
cidade de Villa de la Concepcion, pôde presenciar a visita de índios na cidade, com o objetivo de comercializar.

Havia trinta e tantos índios na Villa del Rio Cuarto, que tinham chegado para comercializar, e eram convidados do governo enquanto eles lá permaneciam. Sua aparência não difere dos índios norte-americanos; e, assim como esses, eles são viciados em beber em excesso. Eles disponibilizavam para venda ponchos, mantas e bolas. [...] Entre eles, havia muitos Cristianos [cristãos], como eram chamados os [brancos] nascidos em algumas províncias, que eram levados quando crianças e criados entre os índios, até que eles preferissem aquele modo de vida a qualquer outro. [...] Esperando obter informações de um grupo que havia chegado à pousada, eu pedi um copo grande de aguardiente, e comecei a interrogar o cacique através de um jovem Cristiano, que atuou como intérprete. Em relação à natureza da região em que viviam, ele me informou que não era o pampa, e sim um lugar densamente arborizado. Ele também me disse que eu poderia acompanhá-los em perfeita segurança, já que eles eram um povo pacífico, que nunca perturbava aqueles que não os incomodava. Pessoalmente, eu não tenho dúvidas disso, eu provavelmente estaria a salvo; mas, é mais do que provável que me roubariam tudo. $\mathrm{Na}$ verdade, muitos nativos pela estrada me disseram que um estrangeiro estava menos suscetível ao perigo dos índios do que eles próprios; e há uma boa razão para isso, já que se sabe (ou, pelo menos, é dito) que um exgovernador do departamento do Rio Cuarto convocou, traiçoeiramente, vinte e cinco ou trinta índios para assinar um tratado, e, então, provocou o assassinato de todos eles. ${ }^{25}$

\footnotetext{
${ }^{25}$ MACRAE, op. cit. p. 34-5. No original: "There were some thirty odd Indians in the Villa del Rio Cuarto, who had come in to traffic, and were guests of the government while they remained. Their appearance does not differ from that of our North American Indians; and, like them, they are addicted to the vice of drinking to excess. They had only for sale ponchos, mantas, and bolas. [...]. Among them were several Cristianos, as they are called natives of some of the provinces, who had been carried off when young, and reared among the Indians, till they preferred that mode of life to any other. [...] Hoping to obtain information from a party who came to the posada, I ordered a large glass of aguardiente, and commenced questioning the cacique through a young Cristiano, who acted as interpreter [...] As regards the nature of the country in which they live, he said it was not pampa, but thickly wooded. He also told me that I could go down among them in perfect safety, as they were a peaceable people, and never interfered with those who did not trouble them. I have no doubt that, personally, I should have been safe; but it is more than probable I would have been robbed of everything. Indeed, several of the natives along the road told me that a foreigner was much less exposed to danger from the Indians than themselves; and there is good reason for this, for it is known (or at least is generally stated) that one of the former governors of the department of the Rio Cuarto treacherously induced twenty-five or thirty Indians to come in for the purpose of making a treaty, and then had caused them all to be assassinated."
} 
O excerto acima nos trás comparações interessantes. Sobre os índios, MacRae afirmou que os da Argentina assemelhavam-se aos encontrados nos Estados Unidos. E mais, não há aqui descrições físicas ou adjetivos que os coloque como inferiores em relação à raça branca, embora afirme que eles sofriam do mesmo problema que os do norte: o apreço a bebida. Ademais, eles eram ladrões. Contudo, notamos aqui que ele descreve também a ação traiçoeira de homens brancos, que não honraram com sua palavra em suas negociações com os índios, ao relatar a emboscada que estes sofreram, sendo todos mortos. Aqui, índios e brancos foram questionados.

Em outra passagem, o autor relativizou novamente os julgamentos sobre os indígenas, ao demonstrar que homens sequestrados por eles, quando se viam livres, muitas vezes desejavam para eles retornar:

[...] Eu fui ver um jovem e sua irmã que haviam sido cativos entre os índios, mas que conseguiram efetuar sua fuga. Eles ficaram cerca de um ano entre os "cristãos"; a mulher se casou, mas o homem ansiava retornar à vida selvagem. ${ }^{26}$

Tais relatos sobre os índios e a relação destes com homens brancos apontaram sempre para duas únicas direções no discurso de MacRae: se havia o perigo de ataques, ele lembrava que os homens brancos também os atacavam; se eram os representantes da barbárie, ele também comentou o fato de que muitos homens brancos não desejavam retornar à "civilização".

Novamente através de um dispositivo discursivo que buscava constatar fatos, o autor aqui nos deixa variadas possibilidades de interpretação. A primeira seria a de que a barbárie naquela região não era uma qualidade apenas dos índios, já que ele observou brancos desejando o mesmo modo de vida. A segunda possibilidade de interpretação é a de que MacRae relativizou a própria ideia de barbárie e da suposta crueldade como característica

\footnotetext{
${ }^{26}$ MACRAE, op. cit., p. 39. No original: [...]" I saw a young man and his sister who had been captives among the Indians, but had succeeded in effecting their escape. They had been about a year among the "Christians," and the woman had married, but the man was pining to return to savage life."
} 
exclusiva dos índios. Lembremos ainda que, se os índios que ele encontrou estavam quase sempre bêbados, são frequentes as descrições que o oficial fez de homens brancos que se fartavam com a bebida nas hospedarias.

Indo além, o oficial buscou analisar os ataques indígenas e suas motivações. Ele afirmou que a região não era boa para os viajantes.

Suas incursões [dos índios] são geralmente feitas à noite, com grande discrição, e seu principal objetivo é afugentar éguas e gados com chifre. Se, na prossecução desse objetivo, eles encontrarem tropeiros ou pastores indefesos, eles geralmente os matam - em parte para evitar que a notícia sobre as suas presenças seja levada ao forte, embora a maioria das mortes seja motivada por um desejo de retaliação, ou por uma predisposição cruel; e é provável que se viajantes caírem em circunstâncias semelhantes, eles partilhem o mesmo destino [morte]. Mas como é contrário aos interesses dos índios percorrerem a estrada principal, e aos dos viajantes, de tomar qualquer outra, esses encontros não acontecem com frequência. Em todo caso, eu não acredito que, para um inglês ou para um americano, o perigo dos índios seja tão grande quanto se pode inferir de alguns gauchos das camadas mais baixas. ${ }^{27}$

Aqui, o autor indica francamente que é melhor encontrar um índio do que um gaúcho católico. Vejamos porque:

Somos todos [norte-americanos e ingleses] conhecidos como hereges, ou devemos supostamente ser. $\mathrm{O}$ derramamento do nosso sangue não é considerado um pecado muito grave e, às vezes, é até mesmo considerado um mérito. Para a gratificação desse ato meritório, deixe que seja adicionada a perspectiva de vantagem pecuniária [monetária], e o herege que se encontrar despreparado, em um lugar solitário, sem nenhuma outra retaguarda do que dois ou três gauchos, tem poucas chances de permanecer vivo. Como

\footnotetext{
${ }^{27}$ MACRAE, op.cit. p. 41-42. No original: "Their inroads were generally made at night, and with great secrecy, and their principal object was to drive off mares and horned cattle. If in the pursuit of this they fell in with defenceless drovers or herdsmen, they usually put them to death - partly to prevent news of their presence being carried to the fort, though most generally from a desire to retaliate, or from a naturally cruel disposition, and it is probable that travellers fallen in with under the same circunstances have shared the same fate. But as it was contrary to the interests of the Indians to follow the main road, or of travellers to take any other, these encounters were not of frequent occurrence. At all events, I do not think that, for an Englishman or an American, the danger from Indians ever was or ever will be so great as that to be apprehended from some of the lower class gauchos."
} 
eles [índios] são covardes, assim como traiçoeiros, seu modo habitual de ataque é se aproximar com um ar civilizado, solicitando fogo ou cigarro, e, no primeiro momento de descuido do viajante, surge uma faca, $\mathrm{e}-{\text { adios } !^{28}}^{28}$

Mais alguns adjetivos foram atribuídos aos índios, como os de covardes, assassinos e traiçoeiros. MacRae compartilhou disso e, embora afirme que os gauchos corriam mais riscos que os viajantes. Informou que norte-americanos e ingleses - que eram considerados como hereges devido à religião protestante - também corriam perigo. Assim, de forma irônica, o oficial apontou que suas mortes não seriam tão "graves", já que os brancos da região não lamentariam tanto a morte de "hereges".

Por fim, embora a imagem aqui seja negativa, notemos que o oficial também justificou os ataques devido à necessidade de não serem descobertos pelos soldados dos fortes próximos onde estavam, ou seja, MacRae aqui explicou que os assassinatos muitas vezes tinham uma razão ligada à própria sobrevivência do indígena. Ademais, no mesmo relato, o oficial exemplificou outra situação que atribuía o mesmo tipo de comportamento cruel a um homem branco que após cometer assassinato refugiou-se entre os índios. Segundo MacRae, ele mostrou-se o mais cruel dentre os da tribo quando saíam em campanhas pelo país:

\begin{abstract}
Desde minha partida de Rosário até minha chegada a San Luis, eu estava ansioso em me juntar com o Coronel Baigorria, um grande homem entre os índios, de quem eu desejava obter um salvoconduto, no caso de aparecer uma oportunidade para eu adentrar na região indígena ao sul; mas, antes da minha chegada, ele havia partido entre eles [índios]. Seu sobrinho, no entanto, estava lá, engajado em uma atividade muito característica [ironia] de tentar
\end{abstract}

\footnotetext{
${ }^{28}$ MACRAE, op. cit. p. 41-42. No original: "We are all known as or are supposed to be heretics, the shedding of whose blood is not considered a very grave sin, and is sometimes even considered a merit. To the commision of this meritorious act let there be added the prospect of pecuniary benefit, and the heretic who finds himself unprepared, and in a lonely place, with no other company than two or three gauchos, stands but little chance for his life. As they are cowardly, so are they treacherous, their usual mode of attack being to approach with a very civil air, requesting fire or a cigar, and at the first unguarded moment of the traveller out comes a knife, and - adios!"
} 
esfaquear um homem com quem ele havia brigado à mesa de jogo, e para fazer isso, executou diversas tentativas infrutíferas ao longo do dia. O Coronel Baigorria é um Puntano, ou um nativo de San Luis de la Punta, que cometeu um assassinato e, para escapar da condenação, refugiou-se entre os índios, onde foi mantido por um tempo em cativeiro fechado, mas, posteriormente, lhe foi permitido acompanhar o grupo [de índios]; nessas ocasiões, cometeu diversas atrocidades, mais do que os próprios índios, depois das quais lhe foi concedida plena liberdade. Ele logo se tornou um homem de grande respeito entre eles [índios], e era o plenipotenciário deles em todos os tratados ou transações com as diferentes cidades ou províncias na fronteira. Após a queda de Rosas, o último ditador da Confederação, o General Urquiza conseguiu, através de Baigorria, fazer um tratado com os índios em uma base mais sólida, do que qualquer outro tinha conseguido até então; e, até o momento em que eu deixei o país, seus termos de pagar tributos em éguas de um lado, e se abster de incursões predatórias de outro, tem sido estritamente observados, e os efeitos benéficos [do tratado] se expressavam em uma maior confiança com a qual as pessoas ao longo da fronteira dedicavam-se à criação de gado. Além disso, Urquiza fez de Baigorria um coronel, de seu sobrinho, um capitão do exército, e para gerar maior confiança entre as duas raças, adotou o arriscado plano de colocar no comando de um dos fortes da fronteira o primeiro [Baigorria], que, conforme me foi dito, o comandaria com os índios. ${ }^{29}$

Neste excerto, vemos novamente aspectos interessantes, não apenas por ele ter sinalizado novamente que homens brancos da Argentina podiam ser

\footnotetext{
${ }^{29}$ MACRAE, op. cit., p. 60. No original: "I had been desirous, from the time of my departure from Rosario until my arrival in San Luis, to fall in with a Colonel Baigorri a great man among the Indians from whom I wished to obtain a safe conduct, in case opportunity should offer for me to penetrate into the Indian country to the southward; but before my arrival he had gone off among them. His nephew, however, was there, engaged in the very characteristic occupation of trying to stab a man with whom he had quarrelled over the gambling table, and to accomplish which he made several unsuccessful efforts during the day. Colonel Baigorri is a Putano, or a native of San Luis de la Punta, who committed murder, and, to escape the penalty, took refuge among the Indians, where he was kept for a while in close captivity, but was allowed, subsequently, to accompany plundering parties, and on these occasions committed more atrocities than the Indians themselves, after which he was granted full liberty. He soon became a man of great consideration among them, and was their plenipotentiary in all treaties or transactions with the different towns or provinces on the frontier. After the fall of Rosas the late Dictator of the confederation General UrquSza succeeded, through Baigorri, in making a treaty with the Indians on a firmer basis than any they had had before; and up to the time I left the country, its conditions paying a tribute in mares on one side, and abstaining from predatory incursions on the other had been strictly observed, and the beneficial effects were apparent in the greater confidence with which people along the fron- tier devoted themselves to raising cattle. Besides this, Urquiza had made Baigorri a colonel, and his nephew a captain in the army, and, to create greater confidence between the two races, had adopted the rather dangerous plan of placing one of the frontier forts under charge of the former, who, I was told, would man it with Indians."
} 
tão bárbaros quanto os índios, mas também por demonstrar conhecer um pouco sobre os acordos políticos feitos entre brancos e índios e sobre quem se destacava nesta tarefa. MacRae se referiu acima a uma figura importante durante o governo de Urquiza na Confederação Argentina, Manuel Baigorria. De acordo com o historiador Gabriel Passetti, Baigorria de fato viveu décadas nas tolderias da tribo dos Ranquel e passou a ser considerado um "cacique branco", o qual teve grande influência no crescimento da miscigenação entre brancos e indígenas nas chamadas zonas de contato e foi o principal colaborador na intermediação de acordos entre índios e brancos durante o governo de Urquiza. ${ }^{30}$ MacRae desejava obter um "salvo-conduto" de Baigorria, o que remete ao interesse do viajante em estar entre os indígenas e conhecer sua cultura, ou, no caso de um encontro inusitado com estes, mostrar o documento e evitar um fim trágico. Ademais, vemos aqui a descrição de seu sobrinho, branco e criado entre brancos, mas agindo de forma nada "civilizada" em sociedade.

MacRae criticou ambos, índios e brancos, mas, como vimos, também ofereceu algumas respostas para a ação indígena. Creio que isso não deva passar despercebido, pois em geral, o que se costuma ver em relatos de homens que não possuem uma ideia romantizada do indígena, é somente a representação da barbárie, sem nenhuma racionalidade em suas ações. Ao mesmo tempo em que MacRae não se desdobrou em uma visão romantizada do índios, e aqui reafirmo que ele muitas vezes colocou índios e brancos, em geral os pobres, no mesmo patamar. Ambos poderiam ser desumanos e cruéis.

No dia de natal, o oficial relatou a passagem de uma banda militar composta exclusivamente por negros. Em sua descrição, todos estavam bêbados e tocavam de forma pouco harmoniosa, se demorando nos lugares até conseguirem dinheiro:

\footnotetext{
${ }^{30}$ Cf: PASSETTI, Gabriel, op. cit., p. 85.
} 
O dia de Natal teria passado sem o nosso conhecimento, se não fosse a serenata de uma banda militar composta inteiramente por negros. Estavam todos bêbados e faziam um barulho tão infernal, que nós pagamos, sem pestanejar, para que parassem com sua música; na verdade, eles ameaçaram continuar tocando até que nós os pagássemos. É o costume deles, assim como dos nossos alguns negros em algumas partes do Sul, sair por aí nessa ocasião, e dançar ou tocar instrumentos na frente de uma casa, até que recebam um presente. ${ }^{31}$

Sabemos que MacRae era de uma família de fazendeiros da Carolina do Sul, e, portanto conviveu em um ambiente de escravidão. Tal como os índios, ele os descreveu como bêbados. Mas nada além disso sobre eles foi relatado. Como já dito, em geral ele não carregou seu relato com imagens explicitamente negativas. Mas escolheu determinados temas para tratar: alguns líderes locais, os quais falou rapidamente, os índios e os gaúchos. Lembro novamente aqui que o ato de beber demasiadamente também foi descrito entre os homens brancos. Todavia, do que pude observar, quando se tratou de índios ou negros, a associação destes com o alcoolismo foi imediata. Além disso, assim como fez com os índios, o oficial comparou os negros da Argentina com os do sul dos Estados Unidos. Nem melhores, nem piores, apresentando características comuns e os mesmos hábitos culturais. Os índios dos Estados Unidos eram, assim como muitos grupos da Argentina: pouco confiáveis.

Ao chegar a San Jose del Moro, encontrou um norte-americano que ali prosperava e se encontrava feliz:

A melhor casa na cidade é a de um "New Yorker", chamado Van Sice, que, após estabelecer diversas prensas em várias partes da América do Sul, e buscar fortuna de outras maneiras honrosas,

\footnotetext{
${ }^{31}$ MACRAE, op.cit., p. 35. No original:" Christmas day would have passed away without our knowledge, but for the serenade of a military band composed entirely of negroes. They were all drunk, and made such an infernal noise, that we paid them pretty roundly to stop their music; indeed, they threatened to play until we did pay them.- It is their custom, like that of our negroes in some parts of the south, to go round on this occasion, and either play or dance in front of a house until they receive a present."
} 
finalmente se casou com uma nativa inteligente e muito aprazível, e se estabeleceu em San Jose. Sua variedade de mercadoria foi a melhor que eu vi na parte oriental da cordilheira, e ele parecia estar fazendo um próspero negócio. ${ }^{32}$

MacRae, diferentemente de Gilliss, demonstrou a capacidade de um yankee em manter-se enérgico mesmo após viver anos na América do Sul, sem ser tomado por qualquer apatia ou degeneração de seu caráter. Mais, atribuiu a uma nativa não apenas a qualidade da beleza, mas também da inteligência. É evidente que o oficial se orgulhou em encontrar um norteamericano cujo negócio era o mais próspero que encontrou na região, ainda que se tratasse de um nortista. Vemos, portanto, que os melhores elogios foram destinados a um yankee, que levou aspectos de modernidade para a América do Sul - a imprensa - e depois, estabeleceu-se em uma cidade e montou o melhor mercado do interior da Argentina. Assim, embora MacRae tenha elogiado os locais como "civis, pacíficos e de boa índole", é inegável que o elogio destinado ao nortista possui uma carga maior de positividade.

O viajante, novamente diferentemente do que vemos em Gilliss, em poucos momentos demonstrou irritação com os locais. O pior para ele parece ter sido a convivência durante a viagem com alguns arrieros que o guiou. De San Luis para Rosário, os arrieros contratados pelo oficial foram motivos de muitas críticas, pois eram calados, pouco prestativos e não sabiam controlar a guarnição de alimentos preparados para a viagem - os quais se resumiam basicamente em carne seca (charque), a qual era hidratada com água quente na hora do jantar. MacRae os representou de forma bastante negativa e afirmou, por exemplo, que ao terminar seu trajeto, deles não obteve gratidão

\footnotetext{
${ }^{32}$ MACRAE, op.cit., p. 30. No original: "The best house in the town is that of a "New Yorker," named Van Sice, who, after establishing several printing-presses in various parts of South America, and pursuing fortune in other honorable ways, finally married an intelligent and very comely native, and settled down in San Jose. His assortment of merchandise was the best I had seen on the eastern side of the cordillera, and he appeared to be doing a thriving business."
} 
ou qualquer tipo de afeto, nem mesmo quando ofereceu suas cobertas juntamente com o pagamento:

Paguei ao arriero a soma acordada para o meu transporte de San Luis (sessenta e cinco dólares ${ }^{33}$ ), dei a ele todos os meus cobertores e alguns equipamentos de equitação, e o dispensei, um tanto quanto contente por me livrar dele. $O$ patife tinha tão pouca decência que colocou meus cobertores à venda diante dos meus olhos, menos de dois minutos depois de recebê-los. Era bem evidente que ele não guardava ideias românticas de afeto solidário. Eu fui obrigado a vender minhas selas, freios, e coldres a fim de levantar recursos para pagar as despesas rio abaixo; porque eu fui reduzido economicamente, até chegar ao último extremo. ${ }^{34}$

MacRae pareceu se incomodar muito com a rusticidade encontrada nesses homens pouco dados a conversas bem humoradas ou a interação durante todo o percurso. O comportamento deles tornou sua viagem solitária e mais difícil. Por outro lado, podemos imaginar a indignação do oficial que ofereceu seus pertences àqueles homens, mas eles rapidamente os venderam. Ao que me parece, a dissensão entre ele e seus arrieros era mútua e estes, não disfarçaram seus sentimentos.

Outro momento em que MacRae deixa transparecer sua irritação, e, dessa forma, sua visão negativa sobre o outro, apareceu em sua descrição sobre sua passagem pelo porto de Buenos Aires, da onde partiria para os Estados Unidos. A cidade quase não apareceu em seu texto, não fosse o seu relato sobre a enervante burocracia que enfrentou na alfândega:

Eu cheguei em Buenos Aires sem dinheiro e sem possibilidade de fazer um saque, de tal forma que eu estava em uma situação

\footnotetext{
${ }^{33}$ Utilizando a fórmula apresentada em nota no Capítulo 1, temos que 65 dólares em 1852 correspondem, grosso modo, a cerca de 1.490 dólares.

${ }^{34}$ MACRAE, op. cit., p. 40. No original: "Paid the arriero the sum agreed on for my transportation from San Luis, (sixty-five dollars,) gave him all my blankets and some other riding gear, and dismissed him, rather glad of the riddance. The rascal had so little grace as to offer the blankets for sale before my eyes within two minutes after he had received them. It was very plain that he had no romantic ideas of sympathetic affection. I was obliged to sell my saddle, bridle, and holsters, in order to raise means to pay expenses down the river; for I was reduced to the last extremity in money matters."
} 
desesperadora. Contudo, o Comodoro McKeever me ajudou, dando uma ordem a Purser Gulick, de Jamestown, para liberar o montante do ordenado que me era devido. Os funcionários da alfândega em Buenos Aires pareciam ter especial prazer em jogar em meu caminho todos os obstáculos que o seu sistema infame permitia. Antes de tentar desembarcar a minha bagagem, eu fiquei em resguardo e, dito isso, além de apetrechos pessoais, eu tinha um conjunto de instrumentos, com os quais eu me propunha a fazer uma série de observações, e fui informado de que não haveria qualquer dificuldade de passar [pela alfândega]. Com base nessa garantia, eu desembarquei e coloquei as minhas bagagens em um carrinho, esperando não ter nenhum problema além de simplesmente as abrir no atracadouro.

Muito pelo contrário, eu fui obrigado a ir até a alfândega para obter uma permissão; e de lá, fez-se necessário ir a uma loja que vendia papel timbrado; então, encontrar algumas pessoas que escreveriam a permissão na devida forma; e finalmente para os coletores de impostos, para que tudo fosse assinado. Acreditando que os meus problemas haviam terminado, eu fui ao atracadouro, onde descobri, que embora eu tivesse desempacotado tudo na frente dos oficiais do resguardo, eu seria obrigado a carregar tudo para alfândega, porque, verdadeiramente, alguns de meus equipamentos pareciam novos. Na alfândega, foi necessário passar pelo mesmo processo de desempacotar e tudo isso à luz do sol, com a temperatura do ar em cerca de $90^{\circ} \mathrm{F}\left[32^{\circ} \mathrm{C}\right]$, e a do meu temperamento em $212^{\circ} \mathrm{F}\left[100^{\circ}\right.$ C]. Quando a curiosidade dos funcionários foi satisfeita, me foi dito, em voz baixa, que os instrumentos não poderiam passar, porque eles não eram comestíveis, como se alguma vez alguém supôs que instrumentos magnéticos fossem comestíveis. Cordialmente desejando que os oficiais da alfândega fossem alimentos para vermes, eu recorri ao coletor de impostos e, conversando muito livremente com ele, consegui uma ordem para que as minhas coisas passassem. Depois de fazer uma série de observações em Buenos Aires e Montevidéu, eu embarquei na barca norte-americana "Almeida", Captain Kearney, sem nenhum incidente até minha chegada em New York, depois de uma viagem de cinquenta e seis dias. ${ }^{35}$

\footnotetext{
${ }^{35}$ MACRAE, op.cit., p. 42 - 43. No Original: "I arrived in Buenos Ayres without money, and was unable to get a draft cashed; so that I was in a strait. Commodore McKeever relieved me, however, by giving an order on Purser Gulick, of the Jamestown, for the amount of pay due me. The custom-house officials in Buenos Ayres appeared to take particular delight in throwing as many obstacles in my way as their infamous system admitted. Before attempting to disem- bark my baggage, I went to the resguardo, and stated that, besides personal equipage, I had a set of instruments, with which I proposed to make a series of observations, and was told that there would be no difficulty in passing them. Acting on this assurance, I
} 
MacRae aqui foi explicito e usou de ironia, criticou a burocracia do porto argentino e seus funcionários. Para ele não havia justificativa para tantas etapas no processo de desembaraço aduaneiro. Ele muito possivelmente acreditava que, por estar a serviço da Expedição, não seria importunado. Subtende-se, no trecho acima, que os funcionários eram ou malintencionados, já que colocavam obstáculos sem fim em seu caminho, ou incapazes, já que supostamente eles argumentaram que equipamentos científicos não eram comestíveis - essa questão provavelmente estava relacionada às modalidades das tarifas alfandegárias argentinas. MacRae omitiu o fato de que os Estados Unidos, naquele momento, eram um país com uma rígida política aduaneira e que um viajante que embarcasse com vários equipamentos tecnológicos possivelmente encontraria a mesma resistência por parte de fiscais em portos norte-americanos.

Como já dito, seus instrumentos quebraram na primeira viagem, fato que fez com que ele tivesse que voltar, às suas próprias custas e refazer o percurso a fim de obter as medições. E foi o que fez, retornando para a América do Sul cerca de um ano depois de sua primeira viagem. Lembro aqui que ele havia deixado uma moça em Valparaiso, com quem pretendia se casar. Em sua narrativa curta sobre a segunda viagem, nos conta:

Rosário não passou a mesma boa impressão na minha segunda visita, como fez na primeira. As casas não pareciam tão boas, nem

landed and got my things into a cart, expecting to have no other trouble than merely opening them on the mole.

On the contrary, I was obliged to go to the custom-house for a permit; and from the custom- house it was necessary to go and look for a shop where stamped paper could be bought; then to find some person who would word the permit in due form ; and finally to the collectors, to get it signed. Supposing my troubles over, I repaired to the mole, where, after unpacking in presence of the officers of the resguardo, I found that I should he obliged to carry everything to the custom-house, because, forsooth, some of the instruments looked new. At the custom-house it was necessary to go through the same labor of unpacking again and all this in the sunshine, with the temperature of the air about 90, that of my temper at 212. When the curiosity of the clerks was satisfied, I was told quietly that the instruments could not pass, because they were not comestibles as if anybody ever supposed that magnetical instruments were comestible. Heartily wishing that the custom-house officers were food for the worms, I repaired to the col- lector, and, by speaking my mind very freely to him, succeeded in getting an order to have the things passed. After making a full set of observations in Buenos Ayres and Montevideo, I embarked on board the American barque "Almeida," Captain Kearney, and without special incident arrived at New York, after a passage of fifty-six days." 
as vestimentas dos estrangeiros, em estilo europeu, pareciam tão elegantes. Eu suponho que a razão disso é que, na minha primeira visita, eu a vi [Rosário] depois de atravessar os pampas, onde quase todas as cidades tem um aspecto de decadência, enquanto da segunda vez, eu tinha acabado de sair de New York. No entanto, é um lugar extremamente florescente e, até mesmo durante minha curta ausência, deu indícios de um aumento da prosperidade, na organização de um clube para residentes estrangeiros, no qual divertimentos ligados à vida civilizada foram oferecidos para a melhor classe de cidadãos e visitantes; e [também] no estabelecimento de agências para algumas das grandes casas comerciais inglesas e alemãs, assim como no crescimento da cidade em si. ${ }^{36}$

MacRae, ao contrário de Gilliss, tinha a noção de que sua visão podia ter sido influenciada por algo anterior à viagem. Nesse sentido, esse excerto é muito importante, pois demonstra que, ao contrário de Gilliss, ele refletiu sobre aspectos que influenciavam a sua visão sobre o outro, ainda que prevaleçam as constatações negativas. $\mathrm{O}$ viajante, quando retornou à Argentina, afirmou não ter visto com os mesmos olhos as cidades visitadas, mas, foi capaz de atribuir sua falta de encanto ao fato de ter acabado de sair da desenvolvida e populosa Nova York. Apesar de agora enxergar a cidade como rústica, assim como seus habitantes, reconheceu que houve progresso em cada cidade que ele havia visitado anteriormente.

MacRae, ao informar sobre a mudança de país de um antigo conhecido seu, novamente faz constatações sobre as diferenças culturais. Nessa passagem, interessa novamente o olhar de MacRae sobre as circunstâncias em que tal mudança lhe foi imposta:

\footnotetext{
${ }^{36}$ MACRAE, op.cit., p .43. No Original: "Rosario did not make so great impression at my second visit as at the first. The houses did not look so fine, nor did the dresses of foreigners, attired in the European style, appear so elegant. I suppose the reason was, that on the first visit I saw it after crossing the pampa, where nearly all the towns have an aspect of decay, while on the second I was fresh from New York. Nevertheless it is an exceedingly thriving place, and even during my short absence gave evidence of increased prosperity, in the organization of a club of foreign residents, where the amusements incident to civilized life were afforded to the better class of citizens and visitors; and in the establishment of agencies to some of the large English and German commercial houses, as well as in the increased size of the town itself."
} 
Cheguei a Mendoza ao meio-dia do dia 20, e descobri que minha bagagem havia chegado três dias antes. Meu amigo, Don Santiago Arcos, bondosamente tomou conta dela, adicionando, assim, mais um aos muitos favores que eu já lhe devia. Como eu já mencionei o nome do cavalheiro, talvez seja bom declarar que ele é um dos homens mais inteligentes que eu conheci no Chile, mas, infelizmente, sua constituição física não combinava com o clima daquele país; e seus tios, "Los Senores Varas and Valdivieso", insistiram na sua remoção para o [clima] mais afável de Mendonza. Assim, ele foi arrancado de todos os seus laços e forçado a viver entre estranhos. Esse impulso de uma coação amigável talvez não seja compreendida pelo nosso povo, mas no Chile, onde a autoridade de um pai ou de um guardião é absoluta, isso é encarado como uma questão natural. ${ }^{37}$

Aqui pela primeira vez ele mencionou o clima, mas a correlação que fez é diferente daquela realizada por Gilliss, já que ele não faz uma relação de um ou de outro clima desses países como degeneradores. A decisão de ir para uma cidade com um clima mais ameno como o de Mendoza certamente estava associada à saúde de Santiago Arcos e, nesse período, era comum em muitos lugares do mundo a recomendação médica de "mudança de ares" para o tratamento da saúde. Aqui, portanto, MacRae informou que os locais compreendiam que algumas pessoas se adaptavam melhor em determinados climas.

MacRae, diferentemente de Gilliss, evitou tomar partido sobre as questões políticas que se encontravam tensas na região. Em sua segunda viagem, ao chegar a San Luis de La Punta, ele mencionou o fato de ter ocorrido eleições, mas voltou seus olhos para mencionar as comemorações,

\footnotetext{
${ }^{37}$ MACRAE, op.cit., p. 64. No original: "Reached Mendoza at mid-day of the 20th, and found that my baggage had arrived three days before. My friend Don Santiago Arcos had kindly taken charge of it, thus adding one more to the many favors I already owed him. As I have mentioned this gentleman's name, it may be as well to state that he is one of the most intelligent men I ever met in Chile, but unfortunately his constitution did not suit the climate of that country ; and his uncles, "Los Senores Varas and Valdivieso," had insisted on his removing to the more genial one of Mendoza. He was thus torn from all his associations and forced to live among strangers. This over-exertion of friendly compulsion may not be understood among our people, but in Chile, where the authority of a parent or guardian is absolute, it is looked upon as a matter of course."
} 
observando que encontrou os homens já bêbados e como de costume, jogando cartas.

Não é possível afirmar as razões pelas quais se eximiu de emitir opiniões sobre um país que se encontrava em meio a tensões políticas. Provavelmente o receio da manipulação de seus escritos por Gilliss, diante da tensão que vimos existir entre eles, pode ter influenciado a escassez de informações. De todo modo, o excerto acima apresentou uma cena nada positiva: homens bêbados, em um ambiente de jogo, comemorando um evento político.

Quando o autor, já no final de sua viagem, atravessou a cordilheira e chegou ao lado chileno, surgiu então uma narrativa que diz muito sobre o que, de fato, ele pensou sobre a Argentina e que tentou omitir ao longo do relato:

Nós estávamos agora no início dos assentamentos. Terras cultivadas, árvores frutíferas, cabanas confortáveis, rostos sorrindo, olhos brilhando, e toda a indicação de indústria e inteligência superior nos sinalizam de que estamos no Chile. Nenhum contraste pode ser tão grande quanto os dois lados da cordilheira em quase todos esses aspectos. A natureza, em primeiro lugar, tem sido mais abundante no lado chileno. Onde há terra suficiente sobre as rochas para cultivar, onde há água para irrigação; e a quase total ausência de conflitos políticos entre os remotos habitantes, afastados das grandes cidades, os deixaram [chilenos] pensando em nada mais que não fosse o melhoramento das condições materiais. Um bom mercado para o seus produtos está próximo, e as boas estradas levam a ele; de modo que não há desculpas, exceto pela preguiça, que os impeça de se valerem de seus lucros e os chilenos são os menos indolentes de qualquer raça hispânica. ${ }^{38}$

\footnotetext{
${ }^{38}$ MACRAE, op.cit., p. 61. No original: "We were now at the beginning of settlements. Cultivated lands, fruit-trees, comfortable huts, smiling faces, bright eyes, and every indication of industry and superior intelligence, notified us that we were really in Chile. No contrast can be greater than the two sides of the cordillera in nearly all these respects. Nature, in the first place, has been more bountiful to the Chilean side. Where there is soil enough on the rocks to cultivate, there is water for irrigation ; and an almost total absence of political strife or feeling among the inhabitants remote from large towns, has left them nothing to think of but the improvement of their worldly condition. A good market for their produce is at hand, and good roads lead to it; so that there is no excuse, except laziness, to prevent them from availing themselves of its benefits and the Chileans are the least indolent of any of the Spanish race."
} 
Vemos que o oficial se posicionou francamente sobre a imagem geral que tinha sobre os dois países, e, sua visão da Argentina, ao contrário do que muitas vezes poderíamos ter acreditado, devido a margem que suas constatações nos davam para interpretações variadas, se tornou clara. Aqui, seu julgamento é irrefutável.

Neste excerto, o adjetivo preguiça finalmente apareceu e não se pode deixá-lo de lado, pois apesar das enormes diferenças já pontuadas entre as representações de Gilliss e MacRae, aqui encontramos um aspecto em comum. Mas, se Gilliss estigmatizou o chileno com o adjetivo da indolência, MacRae, apesar de a reconhecer, minimizou as representações do capitão da expedição ao afirmar que os chilenos são os menos indolentes entre os da "raça" espanhola. Por outro lado, nos disse algo que não mencionou até o final desse relatório, os argentinos eram preguiçosos e eram mais que os chilenos e de uma forma geral, os descendentes da "raça espanhola" também o eram.

No fim da viagem, MacRae retornou para os Estados Unidos a partir de Valparaíso, tomando lá um vapor em direção ao Panamá e de lá, após alguns dias tomou outro vapor que o levou a seu país, sem a moça chilena que pretendia levar consigo.

Outro aspecto de relevância observado no relatório de MacRae diz respeito à cultura imperial norte-americana. Se, nas descrições de Gilliss esse elemento se mostrou com bastante clareza, em MacRae, ela está presente no discurso, muitas vezes de forma implícita e em outras, como quando ele menciona a ação do nova-iorquino no país, são claras. As representações de MacRae, não sentenciaram de forma direta a Confederação argentina a nenhum destino em especial. Mas, ele deu margem a interpretações e prognósticos negativos nas constatações que realizou.

Os diferentes relatos de viagem que compuseram o relatório final da expedição demonstraram concepções distintas sobre o papel do viajante da 
segunda metade do século XIX. Com isso, procuro demonstrar a partir dos dois autores tratados que não é possível homogeneizar os discursos produzidos por viajantes deste período para a América do Sul, apesar do predomínio de estereótipos negativos sobre a região. 


\section{Considerações Finais}

Na primeira metade do século XIX, os Estados Unidos, assim como muitos países da América do Sul, trabalhavam pela constituição ou consolidação do seu Estado nacional. O governo norte-americano, em processo mais adiantado que os demais países recém-independentes, também dava seus primeiros passos em direção a autoafirmar seu país como preeminente nas Américas. Através de um olhar imperial, em geral, os norteamericanos julgavam os países da América Hispânica como inferiores e necessitados de ajuda para "progredirem" e alcançarem a "civilização". Muitos custavam a crer que isso pudesse ocorrer mesmo com ajuda externa: o lugar no mundo em que estavam e o clima sob o qual estavam submetidos os condenavam a uma eterna letargia.

Vimos que a ciência - e particularmente nesta tese, a Astronomia na medida em que avançava, ajudava o país a inserir-se e destacar-se junto aos países europeus. As armas (Exército e Marinha) dos Estados Unidos também se modernizaram, o que lhes garantiram a vitória na Guerra contra o México em 1848.

Neste contexto, as redes de contato formadas entre Gilliss e as instituições científicas norte-americanas buscaram junto à Europa, especialmente entre os germânicos, a troca de informações e de colaboração científica em esforço cooperativo, em busca por destaque no Novo Mundo e reconhecimento entre as potências da época. Em uma ciência como a Astronomia, vimos que a cooperação transnacional era necessária. No entanto, a escolha por tentar novos caminhos para obter resultados precisos da paralaxe solar a partir da união entre astrônomos norte-americanos e germânicos confirma a intenção norte-americana de se posicionarem no campo científico entre os melhores no mundo sem a tutela dos ingleses. Ademais, embora o método fosse do alemão Gerling, a ação em busca das 
medidas exatas, com observatórios instalados nos Estados Unidos e no Chile, foi dos norte-americanos. Não há dúvida de que eles procuravam capacitação nos saberes estratégicos que poderiam indicar a exata localização em Terra ou no mar.

Todo esse movimento, atrelado as representações construídas principalmente por James Gilliss, indica uma cultura imperial e a intenção por parte do governo norte-americano de se tornar o país influente das Américas. Os Lazzaroni e sua busca pela profissionalização e reconhecimento do desenvolvimento científico tutelado pelo estado nacional, apontam para o mesmo desejo de legitimação e reconhecimento nacional e mundial. Em adição, vimos que este grupo, para tornar possível a ascensão do poder científico, promoveu uma união entre algumas importantes instituições científicas, políticos e influentes oficiais da arma norte-americana que, juntos, tornaram possível a criação da National Academy of Sciences, instituição científica governamental.

Foi em meio a esse movimento que Gilliss tornou possível a expedição astronômica, em um complicado momento pós-anexação de grande parte do território mexicano após a guerra contra o México entre 1846-48. Vimos que mesmo com um grupo pequeno de oficiais participando dessa expedição, cujo objetivo principal era o astronômico, a região que era determinante para tornar viável o fluxo de pessoas para a Califórnia em plena corrida pelo ouro — especificamente o Panamá —, foi visitada e analisada por Gilliss.

Assim, embora a viagem tivesse um propósito fundamentalmente científico, por ser expedição oficial do governo, exigia-se que Gilliss tivesse que dar conta de variados interesses governamentais. Como já analisado, não se pode afirmar que ele tenha realizado esta função com a devida coerência, o que aponta para o fato de que nem sempre essas expedições oficiais forneceram informações "fidedignas" a seus países. Deste modo, concluo que uma viagem financiada pelo governo norte-americano não carregava 
necessariamente quaisquer garantias de coerência e confiabilidade. Vimos uma pequena expedição composta por quatro integrantes habilitados para exercer fundamentalmente a função de astrônomos, relatando os mais diferentes aspectos da política, da geografia e da cultura local. Isso era de fato comum e esperado dos viajantes, porém, aqui cabe compreender que homens despreparados ou carregados de imagens estereotipadas ajudaram a reproduzir uma visão altamente negativa e imprecisa sobre a América do Sul. E não se trata apenas do prognóstico sobre homens e sociedade, como também de sua descrição topográfica, climatológica e etc. Como se sabe, quando um cientista, no caso um astrônomo mapeia a costa de um país, esse corria o risco, mesmo em meados do século XIX, de ser refutado por um especialista e/ou pelos próprios oficiais que compunham a expedição, como de fato ocorreu.

Com isso, podemos concluir que nem mesmo naquele período os relatos de viagem escaparam de críticas de públicos mais exigentes, fato que nos levou a pensar sobre a especialização das ciências, que já estava em efervescência no início da segunda metade do século XIX. Se o público comum assimilava facilmente aquilo que já circulava no imaginário sobre a América do Sul, no mundo científico esses relatórios oficiais poderiam ser questionados. Foi o que ocorreu com a descrição geográfica feita por Gilliss sobre o Chile.

Sua narrativa sobre o Panamá e os yankees com quem viajou, nos informou muito sobre o tipo de homem que iria construir as representações sobre essa região e parte da América do Sul. Elitista, preconceituoso e com os olhos carregados de imagens pré-concebidas, Gilliss não tratou de forma desqualificadora apenas os sul-americanos, ele olhou para seus próprios conterrâneos com desprezo e indignação diante do comportamento rústico que apresentavam. Ao destituir de tais homens a "honra" de serem norteamericanos, Gilliss nos informou sobre a visão de parte da elite que não 
reconhecia as camadas pobres norte-americanas como dignas de carregarem a imagem de seu país para outros lugares do mundo. O papel civilizador baseado no "destino manifesto" não era missão para qualquer um. Até nesse aspecto, a missão só era apropriada para os WASP (White, Anglo-Saxons, Protestants), os quais, esses sim, eram detentores de tal competência e escolhidos para "iluminar" os irmãos do Sul. Aos demais, deveria restar, como vimos em seu relato, o papel coadjuvante, deslocando os Estados Unidos e alguns da Europa como os protagonistas. Não há dúvidas de que os Estados Unidos queriam firmar-se na América Central e do Sul.

Ademais, saliento que nem sempre os relatórios publicados revelam todas as informações que foram repassadas ao governo. Sua ida e volta pelo Panamá denotaram o interesse dos Estados Unidos pela região que já mantinha investidores concentrados na construção de estradas de ferro para facilitar o acesso dos norte-americanos para a Califórnia. Além disso, o tratado firmado entre a Grã Colômbia e os Estados Unidos já indicavam a intenção norte-americana sobre a região. Mas isso, obviamente, não foi tratado pelo oficial em seu relatório.

Foi também no Panamá que as representações negativas dos homens da América Central e do Sul iniciaram. O clima, a decadência das habitações, a religião católica e a incompetência de seus governantes foram o tônus e o norte de suas descrições que condenaram cada país a permanecer em seu estado inferior e muitas vezes repulsivo. Assim, como não houve capacidade de empatia ou de uma análise desprovida de preconceitos, tais representações muitas vezes se provaram discutíveis mesmo para o período em que seu relatório foi escrito. Esse é o caso especialmente do Chile. Vimos que o termo "apatia" predominou em praticamente todos os prognósticos da população chilena.

No entanto, essa tese procurou mostrar que os relatos de viagem científicos, como mencionado, sofriam críticas desde a preparação do texto 
para a publicação. Neste caso em especial, notamos uma crítica que não apenas buscou invalidar ou colocar em dúvida a descrição que tratou dos aspectos geográficos e geológicos do Chile, como também foi em defesa dos chilenos e de sua capacidade de prosperar, indo contra e se defendendo das teorias de raça e clima do período e, portanto, recusando o lugar que era oferecido aos sul-americanos. Gilliss foi criticado por norte-americanos inclusive MacRae, oficial, cartógrafo e da sua equipe de astrônomos na América do Sul - e de forma contundente por chilenos, em especial por Ignacio Domeyko, geólogo, capacitado a questionar o comandante dentro do seu campo de saber. Esse tipo de defesa reforça a tese de que essas nações não se submetiam aos prognósticos dados por europeus e norte-americanos e denotam o papel de agência exercido no período por intelectuais e cientistas da América do Sul. Ademais, Domeyko, embora de origem europeia, havia se naturalizado chileno e lá vivia há mais de uma década quando escreveu seu artigo refutando as descrições de Gilliss. Uma atitude, a bem da verdade, nada apática.

Analisar esse relatório de viagem não foi tarefa simples. A começar pela forma com que o autor escolheu apresentar os resultados astronômicos e a narrativa de tudo o que pôde observar durante os anos em que esteve no Chile. Não há coerência em sua escrita, portanto, indaguei como os oficiais da U.S. Navy puderam creditar fiabilidade ao mesmo. Ao tomar conhecimento das cartas de MacRae e analisá-las, acredito que tal notícia sobre as inconsistências contidas no relatório de Gilliss certamente circulou pela U.S. Navy. Caso isso tenha ocorrido, é provável que pouco desse enorme relatório tenha sido utilizado de forma prática, restando de realmente "útil e digno de credibilidade", as observações astronômicas e as representações negativas sobre a população sul-americana, que, embora nada críveis eram lugar comum naquela época e ainda pouco questionadas entre os norte-americanos. Somamse a isso, as informações estratégicas, ligadas à geopolítica, que não estão 
contidas nesse relatório. Como sabemos, algumas informações e dados dessas expedições científicas eram secretas e não publicizadas nos relatos oficiais.

Os relatos de viagem são fontes interessantes para compreendermos diversos aspectos do país visitado. Mas temos que ter em mente que no encontro entre culturas, há o estranhamento por parte do viajante diante de uma nova sociedade na qual ele tenta, em alguma medida, inserir-se e compreendê-la a partir da referência de sua própria cultura e valores pessoais. Esse estranhamento, associado aos preconceitos e crenças pessoais do viajante, pode também nos ser útil na medida em que revela aspectos da sociedade visitada que não são completamente perceptíveis pelos locais.

Gilliss não errou em afirmar que o Chile ainda dava seus primeiros passos em direção ao "progresso", embora o faça mostrando sua oscilação que predominante relegou o país ao estado da letargia e da inércia, fato que, nesse sentido, não se comprovou verdadeiro, como vimos. Também não errou ao perceber aquele governo como autoritário, já que o considerava uma ditadura quando observou o governo impedindo à oposição de se organizar, fechando jornais e exilando intelectuais que não se enquadravam com sua proposta de governo. Mas, como vimos, o oficial pinçou a ação dos políticos conservadores, ignorando a oposição e seus movimentos e rebeliões das quais parte da população chilena participou ativamente.

Por fim, temos o relato de Archibald MacRae. Aqui, compreendemos a diversidade de falas que podem estar contidas em um único relatório. Incumbido por um oficial superior — que ele não respeitava — a dar conta de uma série de observações que iam muito além da Astronomia, o oficial sulista não apenas se negou a fazê-las, como construiu imagens de forma muito distintas daquelas produzidas por Gilliss. Vimos que o viajante se esforçou em realizar descrições que compusessem um quadro no qual o leitor faria seu julgamento, evitando analisar ou adjetivar a população, ainda que a imputação da América do Sul como aquém dos Estados Unidos fosse inegável. 
Mas nem sempre MacRae conseguiu se isentar da tentação de julgar. Vimos que o oficial relatou muitos gaúchos e índios como bêbados e jogadores, enquanto os arrieros eram ingratos. Mesmo quando falou em uma "simplicidade republicana", não é possível afirmar que ele considerou essa característica como positiva. Devemos lembrar que MacRae era um sulista na América do Sul, sendo que eles, os sulistas, já estavam se havendo com o seu modo de vida e o seu lugar nos Estados Unidos e no mundo. Portanto, se o oficial não denegriu o sul-americano de forma escancarada, e até mesmo foi capaz de perceber-se como observador, isso não foi o suficiente para que ele construísse um olhar fundamentalmente positivo sobre o interior da Argentina. Mas aqui, reitero que a forma como ele relatou, evitando adjetivações e prognósticos, fogem do padrão encontrado nos relatos de viagem oficiais.

Desta forma, ao tratar esse tipo de fonte, o historiador muitas vezes têm gratas surpresas. Se para Gilliss o homem sul-americano era apático, para MacRae esse mesmo homem poderia ser considerado como trabalhador e de boa índole, apesar da preguiça que poderia sentir. Por fim, se para um, os índios demonstravam o pior da natureza humana, para outro, esse lado sombrio podia ser encontrado em qualquer homem. Assim, nem todo relato sobre a América do Sul pode ser considerado como completamente negativo ou, em direção contrária, mas igualmente danoso, completamente romantizado. Ademais, como vimos, não se pode esperar coerência de ideias e de construção de imagens nem mesmo em um único relatório. Ele foi escrito por homens que carregam consigo dúvidas, ambiguidades, certezas baseadas em emoções e uma árdua tentativa em escrever sobre aquilo que não dominavam.

Finalizo minhas considerações com uma análise feita por Mary Anne Junqueira sobre a difícil tarefa de se analisar relatos de viagem: 
As "bordas soltas" e a mutabilidade que caracterizam essas fontes o tornam fascinante, mas permitem que "caibam, no mesmo saco, gatos muitos distintos". Creio que devemos estar atentos a essa peculiar característica do corpus e compreender os recursos que o viajante utiliza, consciente ou inconscientemente, para narrar a sua experiência. ${ }^{1}$

Além do contexto histórico, há de se alinhar o trabalho do historiador ao contexto social, ao qual a nossa fonte e objeto de pesquisa estão inseridos. O desafio do bom historiador não está somente no cuidadoso manejo de suas fontes, mas também em não temer "desconstruí-las". Os relatos de viagem, se por um lado, oferecem ao historiador indícios de um tempo distante, também guardam distorções, falhas e descrições que se aproximam mais daquele que as escreve do que daqueles que foram descritos.

\footnotetext{
${ }^{1}$ JUNQUEIRA, Mary Anne. op.cit., p. 157.
} 


\section{Fontes}

\section{Relatos de viagem \\ Publicados:}

\section{Relatório Oficial da Expedição:}

GILLIS, James Melville. U. S. naval astronomical expedition to the southern hemisphere during years 1849, 50, 51, 52. Washington: A.O.P. Nicholson Printer, 1855.Vls I, II, III, VI.

\section{Relato de viagem do secretário e contador da expedição:}

SMITH, Edmond Reuel. The Araucanians; or, Notes of a tour among the indian tribs of Southern Chile. New York: Harper \& Brother Publisher, 1855.

\section{Cartas}

Manuscritas:

MACRAE, Archibald. [Carta ao pai], 26 de maio de 1852, Santiago (Chile), para MACRAE, Alexander. Wilmington, South Carolina, $3 \mathrm{f}$.

MACRAE, Archibald. [Carta ao irmão], 20 de julho de 1852, Washington D.C., para MACRAE, John C.. Wilmington, South Carolina, $4 \mathrm{f}$.

\section{Jornais}

\section{Estados Unidos:}

The New York Times

\section{Artigo de revista:}

Revista de Ciencias i Letras. "Estudios jeográficos sobre Chile, con ocasion da la publicacion del primer tomo de la obra 'U.S. Naval Astronomical Expedition to the Southern hemisfere during the years 1849-50-51-52.' Por J.M. Gilliss." Vol. 4, 1857. DOMEYKO, Ignacio 


\section{Bibliografia}

ALBERDI, Juan Bautista. La vida y los trabajos industriales de William Wheelwright en la América del Sud. Paris: Libreria de Garnier Hermanos, 1876.

ALMEIDA, Maria Antónia Pires de. As epidemias nas notícias em Portugal: cólera, peste, tifo, gripe e varíola, 1854-1918. História, Ciências, Saúde Manguinhos. Rio de Janeiro, v.21, n.2, abr.-jun. 2014

AMADO, Janaina. "Frontier in Comparative Perspective." Latin American Studies. Washington: v. 19, 1990.

ANDREWES, William (Org.) The Quest for longitude. The proceedings of the longitude symposium Harvard University. Cambridge, MA: Harvard University Press, 1996.

AYERBE, Luis Fernando. Estados Unidos e América Latina. A construção da hegemonia. São Paulo: Unesp, 2002.

AZEVEDO, Cecília. "A santificação pelas obras: experiências do protestantismo nos EUA" Tempo, Rio de Janeiro: no. 11, 2001.

BANDEIRA, Moniz. Presença dos Estados Unidos no Brasil (dois séculos de História). Rio de Janeiro: Civilização Brasileira, s/d.

BANTON, Michael. Racial theories. Cambridge: Cambridge University Press, 1998.

BEIRED, José Luis Bendicho. Breve História da Argentina. São Paulo: Editora Ática, 1996.

BENNETT, Jim. O estatuto dos Instrumentos científicos, e LICOPPE, Christian. Barômetros e Termômetros em França no século XVIII: modalidades históricas da coordenação de medidas feitas á distância. In: GIL, Fernando(coord.). A ciência tal qual se faz. Lisboa: Tipografia Guerra, 1999.

BERCOVITCH, Sacvan. The American Jeremiad. Madison: University of Wisconsin Press, 1978. 
BIEDER, Robert E. Science encounters the Indian 1820-1880. The early years of American Ethnology. Norman: University of Oaklahoma Press, 1989. BIZZARRO, Salvatore. Historical dictionary of Chile. Maryland: Scarecrow Press, 2005.

BORM, Jam. "Defining travel: on travel book, travel writing and terminology". In HOOPER, Glenn; YOUNGS, Tim (ed). Perspectives on travel writing. Hants/Vermont: Ashgate, 2004. Ver também: HULME, Peter and YOUNGS, Tim(Orgs). The cambridge companion to travel writing. Cambridge University press, 2002.

BRADLEY, Peter T. Navegantes británicos. Madrid: Mapfre, 1992.

BROSSE, Jacques. Les tours Du monde de explorateurs. Les grands voyages maritimes, 1764-1843. Paris: Borda, 1983.

BRUCKNER, Martin. Maps, literacy \& national identity. Chapel Hill: University ofNorth Carolina, 2006.

BUCHBINDER, Pablo.Caudillos de pluma y hombres de acción. Estado y política en Corrientes en tiempos de la organización nacional. Buenos Aires: Prometeo, 2014.

CHACRABARTY, Dipesh. Provincializing Europe. Postcolonial tought and historical difference. Princenton: Princenton U. Press, 2000.

CHIARAMONTE, José Carlos. Cidades, Províncias, Estados: Origens da Nação Argentina (1800-1846). São Paulo: Hucitec, 2009.

CLERK, Agnes Mary. A popular history of Astronomy during the nineteenth century. Cambridge University Press, 1885.

COLLIER, Simon. O Chile da Independência à Guerra do Pacífico. In: BETHELL, Leslie. História da América Latina. Da Independência até 1870. São Paulo: EDUSP, 2001.

CRARY, Jonathan. Techniques of the observer: on vision and modenity in the nineteenth century. Massachusetts: Massachusetts Institute of Technology, 1992.

DAILY, Walter: "The Black Cholera comes to the Central Valley of America in 19th Century - 1832 - 1849 and later." Transactions of The American Clinical and Climatological Association.Vol. 119, San Antonio, 2008. 
DE LA FUENTE, Ariel. Los hijos de Facundo: caudillos y montoneras en la Provincia de La Rioja durante el proceso de formación del Estado Nacional Argentino (1853-1870). Buenos Aires: Prometeo, 2007.

DEPREE, A. Hunter."The Founding of the National Academy of Sciences-A Reinterpretation."Proceedings of the American Philosophical Society. Vol. 101, No. 5 (Oct. 31, 1957).

DICK, Steven J. Ski and Ocean Joined: The U.S. Naval Observatory - 18302000. Cambridge University Press, 2003.

DIXON, Chris. Ghost wave : the discovery of Cortes bank and the biggest wave on earth.California: Cronicle Books, 2011.

FIFER, Valerie. United States perceptions of Latin America, 1850-1930: A "New West" South of Capricorn?. Manchester: Manchester University Press, 1991.

FRANCO, Stella Maris Scatena. Peregrinas de outrora: viajantes latinoamericanas no século XIX. São Paulo: FFLCH-USP, Departamento de História, 2005.(mimeo)

FRANTZEN, Allen e NILES, John D. Introduction. In: Anglo-saxonism \& the construction of social identity. Gainesville: University Press of Florida, 1997.

FREDRIKSON, George M. Science, polygenesis, and pro-slavery argument. In: The

black image in the white mind. The debate on Afro-american character and destiny, 1817-1914. New York: Harper \& Row, 1971.

GAZMURI, Cristián. El "48" Chileno: Igualitarios, Reformistas, Radicales, Masones y Bomberos. Santiago del Chile: Editorial Universitaria, 1999.

GERBI, Antonello. O Novo Mundo: História de uma polêmica: 1750-1900. São Paulo: Companhia da Letras, 1996.

GOODMAN Edward J. The explorers of South America. Norman/Londres, University of Oklahoma Press, 1992.

GOODMAN JR., Edward. The explorers of South America. Norman: University of Oklahoma Press, 1992 
GOLDMAN, Noemí; SALVATORE, Ricardo (comp). Caudillismos rioplatenses: nuevas miradas a um viejo problema. Buenos Aires: Eudeba, 2005.

GOULD, Benjamin Apthorp. "Biographical Memoir of James Melville Gilliss". In: THB Annual of the National Academy of Sciences for 1866. Cambridge: Welch, Bigelow, and Company, printers to the University: 1867.

GOULD, Stephen Jay. "Morton's ranking of races by cranial capacity. Unconscious manipulation of data may be a scientific norm. Science, v. 200, maio, 1978.

GUINZBURG, Carlo. Mitos, emblemas, sinais. São Paulo: Companhia das Letras,2002.

HARVEY, Bruce. American geographics: U.S. national narratives and the representation of the non-european world, 1830-1865. Stanford: Stanford U. Press, 2001.

HIGGITT, Rebekah. "What they didn't tell you about the transit of Venus".

HOOPER, Glenn e YOUNGS, Tim. Perspectives on travel writing. Aldershot: Ashgate 2004.

HUFFMAN, Wendell H. "The United States Naval Astronomical Expedition (1849-52) for the Solar Parallax.”. Journal for the History of Astronomy, Vol.22, NO.69/3/AUG, 199.

HULME, Peter e YOUNGS, Tim (org.). The Cambridge companion to travel writing. Cambridge: Cambridge U. Press, 2002.

HUNTER, Mark C. A society of gentlemen. Midshipment at the U. S. Naval Academy 1845-1861. Annapolis: Naval Institute press, 2010.

HUTTER, Lucy Maffei. Navegação nos séculos XVII e XVIII - rumo: Brasil. São Paulo: Edusp, 2005.

JAKSIÉ, Iván. Andrés Belo:scholarship and nation-building in nineteenth century Latin America. Cambridge: Cambridge University Press, 2001.

JOSEPH, LEGRAND e SALVATORE (org.). Close encounters of empire. Writing the cultural history of U.S.- Latin American relations. Durham: Duke University Pres, 1998. 
JUNQUEIRA, Mary A. Velas ao mar. U. S. Exploring Expedition (18381842). A viagem científica de circum-navegação dos norte-americanos. São Paulo: Intermeios, 2015.

"Ciência, técnica e as expedições da marinha de guerra norteamericana, U.S. Navy, em direção à América Latina (1838-1842)". Varia História. Revista do Departamento de História da UFMG, v.23, n. 38, 2007.

"Charles Wilkes, a U.S. Exploring Expedition e a busca dos Estados Unidos da América por um lugar no mundo (1838-1842)", in Tempo. Revista de História do Departamento de História da UFF - Universidade Federal Fluminense. Niterói (no prelo).

, Em tempos de paz. A viagem científica de circum-navegação da U. S. Exploring Expedition (1838-1842). São Paulo: FFLCH, Departamento de História, USP.Tese de Livre Docência em História dos Estados Unidos, nov/2012.

. Ao Sul do Rio Grande - imaginando a América Latina em Seleções: oeste, wilderness e fronteira (1942-1960). Bragança Paulista: EDUSF, 2000.

- Elementos para uma discussão metodológica dos relatos de viagem como fonte para o historiador. In: JUNQUEIRA, Mary Anne e FRANCO, Stella Maris Scatena (Orgs.) Cadernos de Seminários de Pesquisa (v. II). São Paulo: USP-FFLCHEditora Humanitas, v. 1, pp. 44-61. 2011. Disponível em: http://www.fflch.usp.br/dh/leha/cms/UserFiles/File/CSP2.pdf

KAPLAN, Amy e PEASE, Donald (orgs), Cultures of United States imperialism. Durham, Duke University Press, 1993.

LEITE, Miriam Moreira. Livros de viagem (1803-1900). Rio de Janeiro: Editora UFRJ, 1997.

LEONARD, Thomas M. Historical Dictionary of Panamá. Maryland: Rowman \& Litllefield, 2015.

LIMA, Valeria. Uma viagem com Debret. RJ: Jorge Zahar Editor, 2004.

LIMERICK, Patricia Nelson. The legacy of conquest. The unbroken past of the American west. Nova York: W.W. Norton \& Company, 1987. 
LISBOA, Karen. A nova Atlântida de Spix e Martius: natureza e civilização na viagem pelo Brasil (1817-1820). São Paulo: Hucitec, 1997.

Viajantes de língua alemã no Brasil. Olhares sobre a sociedade e cultura (1893-1942). São Paulo: Departamento de História - USP, Tese de doutoramento, 2002 (mimeo).

MACHADO, Maria Helena Pereira. "A ciência norte-americana visita a Amazônia: entre o criacionismo cristão e o poligenismo degeneracionista", in Revista da USP, vol. 75, 2007.

MARTINS, Luciana de Lima. O Rio de Janeiro dos viajantes. $O$ olhar britânico. Rio de Janeiro: Zahar, 2001.

MEINING, D.W. The shaping of America. A geographical perspective on 500 years of History. Continental America, 1800-1867. New Haven: Yale U. Press, 1986.

MILLER, Lillian B. The Lazzaroni: Science and Scientists in Mid-NineteenthCentury America. Washington, D.C.: Smithsonian Institution Press, 1972.

MOREIRA, Marília Arantes Silva. "Expectativas e impasses dos sulistas norte-americanos no Estuário do Prata: a questão da navegação dos rios e a viagem do comandante da U.S. Navy, Thomas Jefferson Page (1853 - 1860)". Artigo de dissertação de conclusão de Mestrado ao Instituto de Relações Internacionais da Universidade de São Paulo, 2013.

MOURA, Gerson. Estados Unidos e América Latina. As relações políticas no século XX. Xerifes e cowboys um povo eleito e o continente selvagem. São Paulo: Contexto, 1990.

O'BRIEN, Thomas. Making the Americas: The United States and Latin America from the age of revolutions to the era of globalization. Albuquerque: University of New Mexico Press, 2007.

PASSETTI, Gabriel. Indígenas e Criollos: Política, guerra e traição nas lutas no sul da Argentina (1852-1885). São Paulo: Alameda, 2012.

PATERSON, T. Carl. A social History of Anthropology in the United States. Oxford \&NY: Berg Publishers, 2001. 
PAULINO, Carla Viviane. O império do atraso: Etnologia, Política e religião nas impressões sobre o Brasil de um inglês radicado nos Estados Unidos (1846-1856). São Paulo: Alameda, 2015.

PINTO, Julio; VALDIVIA, Verónica. ¿Chilenos todos? La construcción social de la nación (1810-1840). Santiago: Lom Ediciones, 2009.

PRADO, Maria Ligia. Natureza e identidade nacional nas Américas. In América Latina no século XIX. Tramas, Telas e Textos. São Paulo: Edusp, 1999.

PRATT, Mary Louise. Os olhos do império. Relatos de viagem e transculturação. Bauru: Edusc, 1999.

ROBERTSON, James Oliver. American myth, American reality. Nova York: Hill \& Wang, 1980.

RODRÍGUEZ, Fermín A. Un desierto para la nación: la escritura del vacío. Buenos Aires: Eterna Cadencia, 2010.

ROHRBOUGH, Malcolm J. Days of Gold:the California gold rush and the American nation. California: California University Press, 1997.

RUBIÉS, Joan Pau. Travel writing and ethnography. In HULME, Peter and YOUNGS, Tim (Orgs). The cambridge companion to travel writing. Cambridge University press, 2002.

SÁ, Maria Elisa Noronha de. Civilização e barbárie: a construção da ideia de nação - Brasil e Argentina. Rio de Janeiro: Garamond, 2012.

SAID, Edward. Orientalismo. São Paulo: Companhia das Letras, 1992.

SALAZAR, Gabriel. Construcción de Estado en Chile (1760 - 1860): democracia de "los pueblos" militarismo ciudadano golpismo oligárquico. Santiago de Chile: Editorial Sudamericana, 2005.

SALAZAR, Gabriel; PINTO, Junior. História Comtemporanea de Chile. Vol. I, Santiago: LOM Ediciones, 2012. 
SALVATORE, Ricardo D. Los lugares del saber. Contextos locales y redes transnacionales en la formación Del conocimento moderno. Buenos Aires: Beatriz Viterbo Editora, 2007.

"The enterprise of knowledge: representational machines of informal Empire" In LEGRAND, Catharine C.; SALVATORE, Ricardo D. (orgs.). Close Encounters of Empire: Writing the Cultural History of. U.S. Latin American Relations. Durham: Duke University Press, 1998.

Imágenes de un Imperio. Estados Unidos y las formas de representación de América Latina. Buenos Aires: Editorial Sudamerica, 2006.

SANTILLI, Daniel; GELMAN, Jorge Daniel; FRADKIN, Raúl Osvaldo (comps.) Rebeldes con causa. Conflicto y movilización popular en la Argentina del siglo XIX. Buenos Aires:Prometeo, 2014.

SCHOULTZ, Lars. Estados Unidos: poder e submissão. Uma História da política norte-americana em relação à América Latina. Bauru: Edusc, 1998.

SLAGLE, Jay. Ironclad captain: Seth Ledyard Phelps and the U.S. Navy, 1841-64. Ohio: The Kent State University Press, 1996.

STANTON, William. American scientific exploration, 1803-1860. Philadelphia: American Philosophical Society, 1991.

STOCKING, George. Victorian Anthropology. New York: The Free Press, 1991.

STUVEN, Ana María. La seducción de un orden. Las elites y la construcción de Chile en las polémicas culturales y políticas del siglo XIX. Santiago: Ediciones de la Universidad Católica de Chile, 2000.

STUVEN, Ana Maria; PAMPLONA, Marco. Estado y nación en Chile y Brasil en el siglo XIX. Santiago: Ediciones UC, 2009.

SUBERCASEAUX, Bernardo. Historia de las ideas y la cultura en Chile. Tomo 1, Santiago: Editorial Universitária, 1997. pp.120-121.

SUSSEKIND, Flora. O Brasil não é longe daqui. São Paulo, Companhia das Letras, 1990.

TERNAVASIO, Marcela. Prólogo. In: El pensamiento de los Federales. Buenos Aires: Editorial El Ateneo, 2009. 
VARGAS, Diego Uribe. Colombia y la diplomacia secreta:1321-1850. Bogotá: Colección Bolsilibros de la Academia Colombiana de Historia, 1973.

VÁRIOS AUTORES, Revista da USP. (Dossiê Brasil dos Viajantes) São Paulo: n. 30, 1996.

VÁRIOS AUTORES. Revista Brasileira de História. (Dossiê Viagens e Viajantes). São Paulo: Anpuh/humanitas, vol.22, n.44, 2002.

WHITE, Richard. It's your misfourtune and none my own. A new history of the American West. Norman: University of Okalahoma Press, 1997.

WILLIAMS, Patrick e CHRISMAN, Laura. Introduction. In: Colonial discourse and post-colonial theory. A reader. Nova York: Columbia University Press, 1994.

WINN, Peter. A Revolução chilena. São Paulo: Unesp, 2009.

ZIFF, Larzer. Return passages: Great American travel writing. 1780-1910. New Haven: Yale University Press, 2000.

ZELINSKI, Wilbur. Nation into state. The shifting symbolic foundations of American nationalism. Chapel Hill: U. of North Carolina Press, 1988. 